\title{
External Events \\ P-204
}

March 2016

United States

Nuclear Regulatory Commission
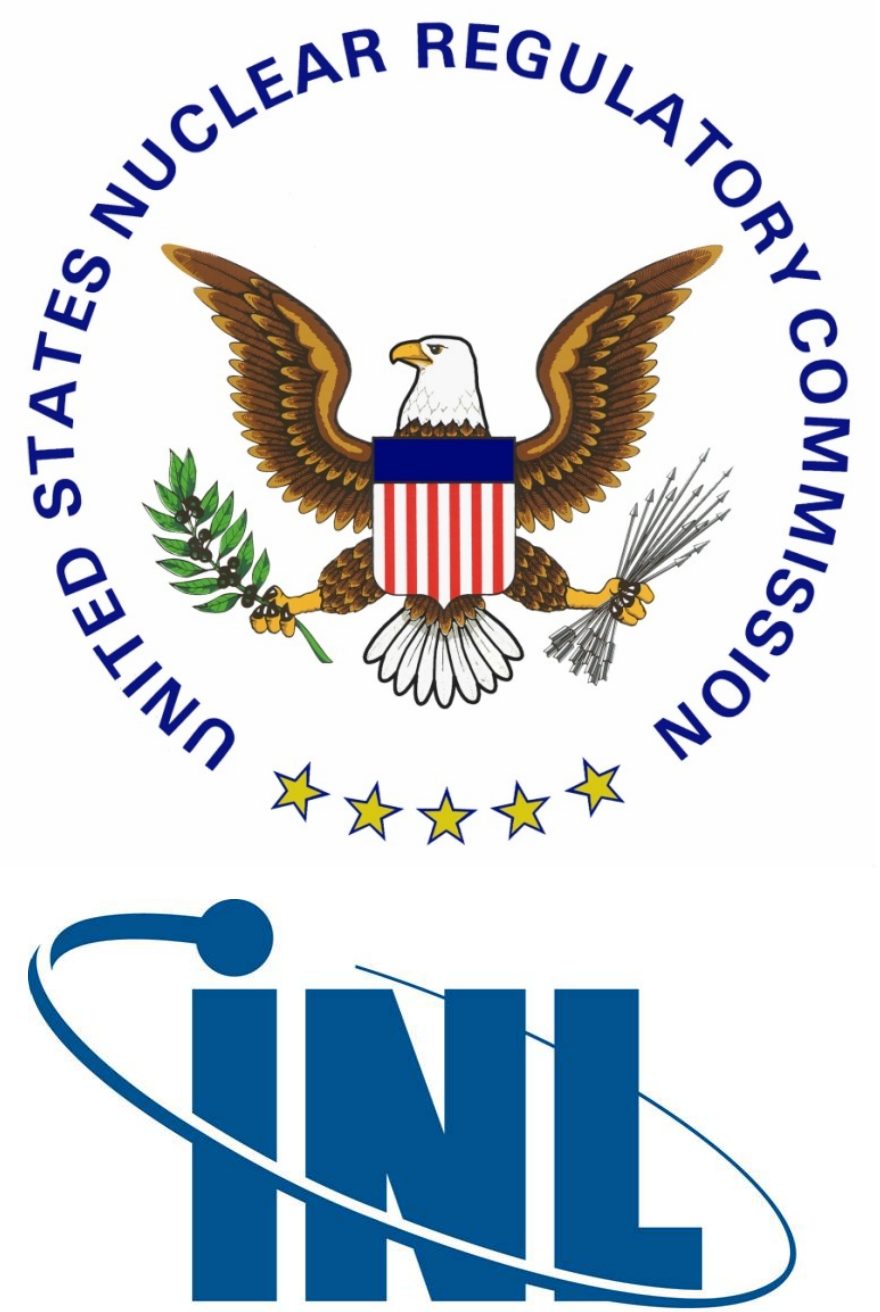

Idaho National Laboratory 


\section{DISCLAIMER NOTICE}

This report was prepared as an account of work sponsored by an agency of the United States Government. Neither the United States Government nor any agency thereof, or any of their employees, makes any warranty, expressed or implied, or assumes any legal liability of responsibility for any third party's use, or the results of such use, or any information, apparatus, product or process disclosed in this report, or represents that its use by such third party would not infringe privately owned rights. 


\section{External Events Risk Analysis (P-204)}

Instructors:

Robert Buell

(208) 526-9400

Robert.Buell@inl.gov

James Knudsen

(208) 526-6432

James.Knudsen@inl.gov

March 15 - 18, 2016 NRC Professional Development Center Rockville, MD 


\section{Course Objectives}

- Overview of External Event Analysis

- Familiarize students with terminology and methodology to understand external event risk analysis.

- Enable students to understand external event analysis submittals from licensees

- History and progression of external events analysis

- Overview of how external events are incorporated into SAPHIRE Level 1 model 


\section{Course Scope}

- Focus on External Flooding, Seismic and Fire Analysis (PRA and SDP)

- Includes Internal Floods and HFO (ㅂigh winds, external Floods, and Other)

- Survey and overview of methods used

- Basic principles and simple examples

- Reference list included for further study

- Individual Plant Examination for External Events (IPEEE)

- Reason every plant has some type of EE analysis

- PRA Standards

- ASME RA-Sa-2009 (Internal Events PRA, includes internal floods)

- ANS/ANSI-58.21-2007 (External Events PRA)

- ANSI/ANS-58.23-2007 (Fire PRA Methodology) 


\section{Outline of Course}

- Background

- IPE/IPEEE

- PRA/PRA-EE standards

- Internal Flood

- Included in IPE not IPEEE

- Other External Events

- High winds, external Flood, and Others (HFO)

- Seismic Analysis

- Fire Analysis

- Fire PRA

- Fire SDP (Overview - Class P108 for detailed Analysis) 


\section{What are External Events?}

- Typically Initiating-Events external to typical plant system operations

- Includes fires, floods, earthquakes, etc.

- Fires and floods inside and outside of the plant

- Loss of off-site power

- Separated from "internal-events" analysis because:

- Unique and specialized methods of analysis

- Dependent type or wide-area effects 


\section{Example External Events}

- Seismic

- Internal Fires

- High Winds and Tornadoes

- External Floods (Tsunami)

- Transportation and Nearby Facility Accidents

- Internal Floods*
- Lightning

- Extreme Temperatures

- External Fires

- Extraterrestrial Activities

- Volcanic Activity 


\section{External Events Found to be Risk Important}

- 1969 - Application of PRA Concept in NPP industry (HTGR-UK)

- 1979 - First Seismic PRA (Oyster Creek)

- 1979 - First Fire PRA (HTGR)

- 1981 - Big Rock Point

- 1982 - Zion/Indian Point

- 1988 - GL 88-20 (IPEs to include internal floods)

- 1989 - NUREG-1150 (Fire and Seismic)

- 1991 - GL-88-20, Supplement 4 (IPEEE)

- Revised in 1995 with supplement 5, which modified seismic requirements 


\section{Purposes of IPEs/IPEEEs}

- Systematically examine plant design, operation, and emergency operation

- Identify plant-specific vulnerabilities to severe accidents and possible scenarios

- Develop understanding of what could possibly go wrong in a plant

- Identify and evaluate means for improving plant and containment performance with respect to severe accidents

- Decide which of these improvements to implement and when

- Perform this examination for selected external events (IPEEE) 


\section{Brief History of GL 88-20}

- 1988-Nov: GL 88-20 issued requesting IPEs

- 1989-Aug: GL 88-20 Supplement 1

- Availability of NUREG-1335 - IPE Submittal Guidance

- 1990-April: GL 88-20 Supplement 2

- List of severe accident management strategies to consider in IPE (NUREG/CR-5474)

- 1990-July: GL 88-20 Supplement 3

- Announced complete of NRC Containment Performance Improvement (CPI) program

-1991-June: GL 88-20 Supplement 4

- IPE for External Events (IPEEE)

- 1995-Sept: GL 88-20 Supplement 5

- Modified recommended scope of seismic analysis to include revised seismic hazard curves (NUREG/CR-1488, LLNL) 


\section{GL 88-20 did not Require a PRA}

- All utilities chose to perform a PRA to address GL 88-20

- PRAs not performed to specified standards

- No requirements specified for data or models

- Not all utilities used PRAs to analyze external events

- Earthquakes and fires can be analyzed via margins approach

- IPE submittal typically not a full PRA (level of detail varies widely, only full-power operation considered)

- IPEs not performed to support risk-informed, performance-based regulation 


\section{External Events Included in Both IPE and IPEEE}

- IPE included consideration of internal flood

- Guidance in NUREG-1335 (1989)

- Results and insights in NUREG-1560 (1997)

- Note that internal flood is now part of internal events PRA standard

- IPEEE included all other external events

- Guidance in NUREG-1407 (1991)

- Results and insights in NUREG-1742 (2002) 


\section{IPEEE Explicitly Addressed}

- Seismic Events

- Internal Fires

- High Winds and Tornadoes

- External Floods

- Transportation and Nearby Facility Accidents

- Any other plant-specific hazards known to the licensee

Remember that the IPE (not the IPEEE) explicitly included internal flooding 


\section{IPEEE Methods Employed}

- Seismic

- Seismic Margins

- Seismic PRA

- Fire

- FIVE (Fire-Induced Vulnerability Evaluation)

- Fire PRA

- Other

- Graded Approach 


\section{IPE Results (Internal Flood)}

- Internal Floods are a small risk contributor for most plants

- Typically $<10 \%$ of CDF

- Important for some because of plant-specific designs

- Water system ruptures that cause failure of multiple systems (directly or through flooding)

- Drains not large enough to prevent buildup or backflow through drains

- Plant-layout - Separation and compartmentalization of system components

- E.g., direction doors swing open 


\section{IPEEE Results}

- Seismic

- Offsite power and on-site electrical equipment dominate risk

- Building and structural failures also important

- Fire

- Switchgear areas and main control rooms (abandonment) important

- High Winds, External Floods, and Other EEs

- Most HFOs screened-out via qualitative analysis

- Some quantitative analyses done on: high winds and tornadoes, external floods, transportation and nearby facilities, lightning (1), snow and ice (1), chemical release(1) 


\section{PRA Standards Include External Events}

- Standards are NOT procedure guides

- Focus is on risk-informed application issues

- ASME standard on PRA includes internal flood (IF) events

- ASME RA-Sa-2009 (February 2009)

- This is fourth revision of original (RA-S-2002, April 2002)

- ANS standard ANSI/ANS 58.21 addresses all other external events (except internal fires)

- Original approved March-2003, published Dec-2003

- Internal fire standard developed (ANS)

- ANSI/ANS-58.23-2007 approved November 20, 2007 


\section{Internal Flooding (ASME PRA Std.)}

Objectives:

- Internal floods (IF) as either an initiator or mitigating system failure are evaluated such that:

- Flood sources within plant are identified

- Flood scenarios/sequences that contribute to CDF and LERF are identified and quantified 


\section{IF Std. - High Level Requirements}

\begin{tabular}{|l|l|}
\hline Designator & Requirement (abbreviated) \\
\hline HLR-IF-A & Flood areas of the plant SHALL be identified \\
\hline HLR-IF-B & Flood sources and mechanisms SHALL be identified \\
\hline HLR-IF-C & $\begin{array}{l}\text { Scenarios for each source SHALL be developed (i.e. } \\
\text { propagation path and affected SSC) }\end{array}$ \\
\hline HLR-IF-D & $\begin{array}{l}\text { Flooding-induced IEs SHALL be identified and } \\
\text { frequencies estimated }\end{array}$ \\
\hline HLR-IF-E & Flood-induced accident sequences SHALL be quantified \\
\hline HLR-IF-F & $\begin{array}{l}\text { Analysis SHALL be documented to support upgrades } \\
\text { and peer review }\end{array}$ \\
\hline
\end{tabular}




\section{Supporting Requirements}

- Each High Level Requirement delineated in terms of more detailed supporting requirements (SR)

- Each SR described in terms of action statements

- E.g., DEFINE, IDENTIFY, USE, CONDUCT

- Each SR linked to one or more of the three Capability Categories, which are defined by the standard in terms of:

- Scope and level of detail

- Plant-Specificity

- Realism 


\section{ANS PRA External Events Standard}

- Original ANSI/ANS 58.21-2003

- Updated ANSI/ANS 58.21-2007

- All EE except internal flood (included in ASME Std.) and internal fire (under development by ANS as a separate std.)

- While plant is at nominal full power

- Includes both seismic PRA and seismic margins assessment (SMA) 


\section{ANS PRA External Events Std.}

- Objective:

- Requirements for EE PRA used to support risk-informed decisions for commercial NPP

- Intended to be coordinated with ASME-RA-Sa-2009 


\section{ANS PRA EE Std High-Level Req.}

\begin{tabular}{|l|l|}
\hline Designator & Requirement (abbreviated) \\
\hline HLR-EXT-A & $\begin{array}{l}\text { All potential EE that may affect the site SHALL be } \\
\text { subject to screening, bounding or detailed analysis }\end{array}$ \\
\hline HLR-EXT-B & $\begin{array}{l}\text { Preliminary screening analysis, if used, SHALL be } \\
\text { performed using a defined set of screening criteria }\end{array}$ \\
\hline HLR-EXT-C & $\begin{array}{l}\text { Bounding analysis, if used, SHALL be performed } \\
\text { using a defined set of quantitative screening criteria }\end{array}$ \\
\hline HLR-EXT-D & $\begin{array}{l}\text { The basis for screening-out of an EE SHALL be } \\
\text { confirmed through a walkdown }\end{array}$ \\
\hline HLR-EXT-E & $\begin{array}{l}\text { The screening-out of an EE SHALL be documented in } \\
\text { a manner that facilitates applying and update the PRA } \\
\text { and that enables peer review }\end{array}$ \\
\hline
\end{tabular}




\section{Internal Events PRA Models are Basic Framework for External Events Analyses}

- Typical approach in External Event PRA

- Characterize hazard (EQ, fire, flood, etc.)

- Frequency and damage to plant (varies by hazard scenario)

- Calculate conditional core damage probability (CCDP) given occurrence of hazard

- E.g., using internal event PRA, set damage equipment to "failed" and calculate conditional core damage probability

- Combine hazard frequency with each CCDP

- For each hazard scenario

- Sum over all hazard scenarios 


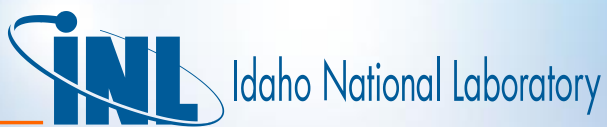

\section{Hazard is New IE - Induces Internal Events}

Initiator

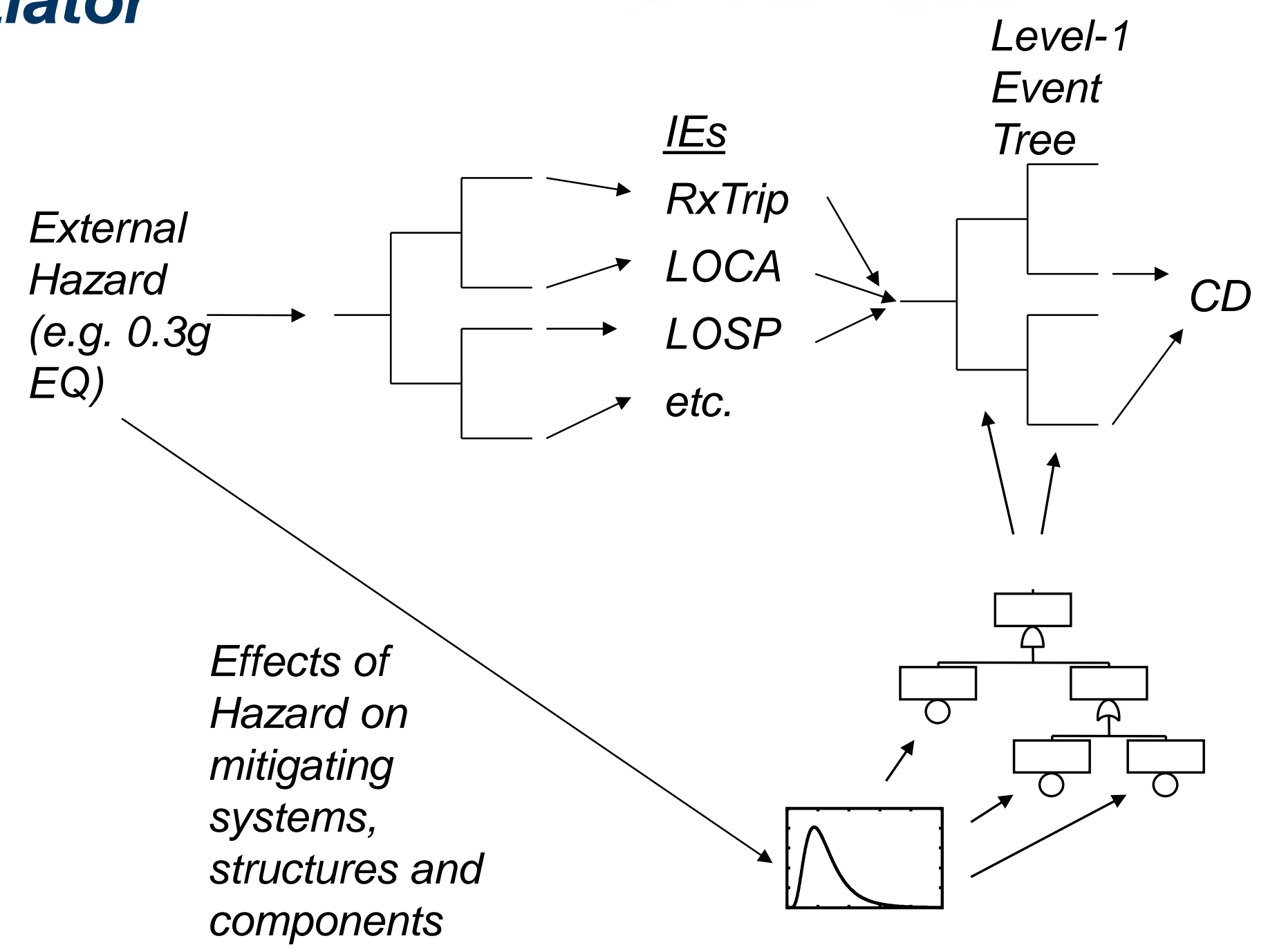




\section{Internal Flooding}




\section{Objectives}

- To become familiar with:

- History of internal flooding analyses and the current approaches being used

- References available on typical internal flooding analysis methods

- Resources for data used in typical internal flooding analyses 


\section{Flood Risk Historically Ignored}

- Reactor Safety Study (WASH-1400, 1975) qualitatively judged flood risk negligible

- Plants designed to withstand probable maximum flood (PMF) External Floods

- Internal flooding was not considered

- Internal Flooding identified as a risk issue 1980 's

- Service water system and condenser ruptures

- Zion (1982) and Indian Point (1983) PRAs 


\section{Sample of Turbine Bldg Flooding Events}

\begin{tabular}{|c|c|c|c|}
\hline Date & Plant & Notes & Result \\
\hline $\begin{array}{l}\text { June } \\
1972\end{array}$ & $\begin{array}{l}\text { Quad } \\
\text { Cities } 1\end{array}$ & $\begin{array}{l}\text { Condenser Circulating water } \\
\text { valve closed inadvertently } \\
\text { causing water hammer } \\
\text { rupture of expansion joint }\end{array}$ & $\begin{array}{l}\text { Rapid flooding of room } \\
\text { containing pumps in several } \\
\text { system }\end{array}$ \\
\hline $\begin{array}{l}\text { April } \\
1977\end{array}$ & TMI-1 & $\begin{array}{l}\text { Condenser circulating water } \\
\text { pump casing split }\end{array}$ & $\begin{array}{l}\text { Rapid flooding of room } \\
\text { containing six pumps }\end{array}$ \\
\hline $\begin{array}{l}\text { Oct. } \\
1976\end{array}$ & Oconee & $\begin{array}{l}\text { Condenser circulating water } \\
\text { isolation valve opened } \\
\text { during maintenance }\end{array}$ & $\begin{array}{l}\text { Lake water spilled into turbine } \\
\text { bldg flooding emergency FW } \\
\text { pumps }\end{array}$ \\
\hline $\begin{array}{l}\text { Oct. } \\
1979\end{array}$ & Dresden 2 & Fire-water leak & $\begin{array}{l}\text { Diesel-generator control } \\
\text { cabinet sprayed }\end{array}$ \\
\hline $\begin{array}{l}\text { Dec } \\
86\end{array}$ & Surry 2 & $\begin{array}{l}\text { Feedwater System elbow } \\
\text { ruptured. }\end{array}$ & $\begin{array}{l}\text { Within minutes of the rupture } \\
\text { the FPS activated. The water } \\
\text { from the sprinklers shorted } \\
\text { out several electrical circuits. }\end{array}$ \\
\hline
\end{tabular}




\section{Sample of Turbine Bldg Flooding Events}

\begin{tabular}{|c|c|c|c|}
\hline Date & Plant & Notes & Result \\
\hline $\begin{array}{l}\text { June } \\
87\end{array}$ & $\begin{array}{l}\text { Palo } \\
\text { Verde } 1\end{array}$ & $\begin{array}{l}\text { Condenser outlet pipe } \\
\text { rupture }\end{array}$ & stairwell flooded \\
\hline $\begin{array}{l}\text { Sept } \\
96\end{array}$ & Fitzpatrick & $\begin{array}{l}\text { Fire Protection water system } \\
\text { pipe rupture, MCC flooded } \\
\text { causing HPCI system to be } \\
\text { unavailable }\end{array}$ & $\begin{array}{l}\text { MCC flooded causing HPCI } \\
\text { system to be unavailable }\end{array}$ \\
\hline $\begin{array}{l}\text { June } \\
98\end{array}$ & $\begin{array}{l}\text { Columbia } \\
\text { River }\end{array}$ & Fire-water pipe rupture & Flooded RHR/LPCS pumps \\
\hline $\begin{array}{l}\text { Nov } \\
02\end{array}$ & $\begin{array}{l}\text { South } \\
\text { Texas-1 }\end{array}$ & $\begin{array}{l}\text { Circ. Water pump casing } \\
\text { ruptured, }\end{array}$ & $\begin{array}{l}\text { instrument cabinet knocked } \\
\text { over, water up to } 4 \mathrm{ft} \text {. }\end{array}$ \\
\hline $\begin{array}{l}\text { March } \\
93\end{array}$ & Perry & SW pipe rupture & RX trip \\
\hline $\begin{array}{l}\text { Dec } \\
91\end{array}$ & Perry & Circ. Water pipe rupture & Rx trip \\
\hline $\begin{array}{l}\text { July } \\
10\end{array}$ & $\begin{array}{l}\text { Susqueha } \\
\text { nna }\end{array}$ & Circ. Water pipe rupture & Rx trip \\
\hline
\end{tabular}




\section{Internal Flood Included in IPE}

- Heightened concern about internal flooding resulted in increased scrutiny

- Internal flood risk incorporated in IPE scope (not IPEEE)

- Other EE analyses delayed to allow NRC/Industry time to finalize scope and methods

- IPEEE trailed IPE by about 2 years

(This has generated inconsistency over the years about whether internal flooding is treated in internal or external events analysis.) 


\section{Internal Flooding Analysis}

- Successive Screening Approach

- Typical of an external event analysis

- Qualitative Screening Analysis

- No Water Sources (Elevation Issues)

- Quantitative Screening Analysis

- Detailed Analysis 


\section{Initialization of Flood Analysis}

- Identify areas of concern

- Both susceptible to flooding AND contain equipment modeled in PRA (Mitigating Systems)

- Plant divided into unique flood locations

- Including areas that can be affected by water spray or steam

- Water retention and flood propagation potential

- Not necessarily separated by water-tight barriers

- Flood sources for each location identified

- Water spray, steam (high energy line break [HELB]) and flood 


\section{Typical Assumptions/Boundary Conditions}

- Only single rupture/flood considered at a time

- Some events already treated by internal events analysis

- LOCAs inside and outside containment

- Temporary potential flooding sources typically ignored

- Short time of exposure, plant staff in local area

- Floods are initiator, not subsequent to others IEs

- Spurious actuation of fire-suppression included

- Flood barriers (e.g., walls) assumed to be effective

- Capacity of drains and doors need to be assessed 


\section{Initial Screening of Locations}

- Screening of locations assuming maximum damage

- Given flooding occurs, all equipment in source location and propagation locations fails

- What alternate equipment (success paths) are available?

- Flood sources for each location identified

- Flood scenarios identified

- Flood source and affected location(s) 


\section{Qualitative Screening}

- Identify independent flood areas/zones

- Independent if flood outside area cannot enter area (without the failure of a barrier)

- Identify flooding sources in each flood area

- Including water capacity and maximum flow rate

- Typical flooding sources are pipes

- Need pipe routing information (can be accomplished via local inspection - Walk-downs)

- Identify equipment in each flood area

- Only equipment needed for safe shutdown (i.e., modeled in PRA) or if damaged, would lead to a reactor trip, is counted

- Includes electrical, control, and instrumentation equipment 


\section{Qualitative Screening (cont.)}

- Flood area screened-out if:

- Area does not contain any safe shutdown equipment, nor any equipment such that if damaged could lead to reactor trip

- However, typically if flood only causes reactor trip with no damage to mitigating equipment, area is screened out

- This scenario is bounded by internal events analysis

- Flooding sources do not have enough capacity to damage equipment 


\section{Qualitative Screening Refined}

- For those flood areas not screened out a more detailed screening can be done

- Determine the critical height of vital equipment

- Determine the maximum height of potential flooding in that area

- Assume worst case flood sources

- Account for drainage out of flood area

- Identify effects other than submergence that might damage critical equipment (e.g., spraying)

- Assess impact of flood propagation out of area (i.e., might this area be important as a flood initiator for another area)

- If max flood height is less than critical height of equipment, if other effects do not impact equipment, and if flood propagating to adjacent areas is not a concern, then can screen out 


\section{Quantitative Screening Analysis}

- Four steps

- Bounding estimate of flooding frequency

- 0.1 or 0.01 (based on amount/type of water piping/equipment)

- Bounding estimate for flood propagation probability

- Human errors and mechanical failures

- For each flood scenario calculate conditional core damage probability

- Screen CDF for each flood scenario against screening criteria

- E.g., 1E-7/yr (flood CDF small compared to internal events)

- Screening should be used sparingly. A 1E-7/yr screening could be a $1 \mathrm{E}-5 / \mathrm{yr}$ if another failure is concurrent. 


\section{Detailed Internal Flooding}

- Flood scenarios that survive screening

- Unique flood areas/locations/zones identified

- SSC's within each area listed

- Flood sources within each area

- Flood frequency within each area estimated

- More realistic estimate of flood damage and damage propagation

- Potential for recovery or mitigation assessed

- Additional (random) failures accounted for

- Core damage frequency calculated 


\section{Flood IE Frequency Estimates}

- Itemized list of potential sources

- Pipe (length)

- Generic pipe rupture rates

- E.g., 4E-10/pipe-section-hour (EPRI TR-100380)

- Sum total flood IE frequency for each location

- Possibly perform further screening based on IE frequency

- Each flood scenario assigned IE frequency

- Data Sources

- INEL Report EGG-SSRE-9639

- EPRI TR-100380

- EPRI 1012302

- EPRI-1013141 


\section{Flood Frequency Estimates}

- Pipe failure frequency from WASH-1400

- Pipe $>3$ in. diameter

- 8.8E-7/seg-yr (median), 2.6E-5/seg-yr (95\%)

- Pipe $<3$ in. diameter

- 8.8E-6/seg-yr (median), 2.6E-4/seg-yr (95\%)

- Expansion joint failure from Individual PRA (NSAC-60, 1984)

$-2.5 \mathrm{E}-4 / \mathrm{yr}$

- Tank rupture from IAEA TECDOC-478 (reliability database, 1988)

$-2.3 \mathrm{E}-4 / \mathrm{yr}$ 


\section{Flood Flow Rate}

- Rate of flooding determines time available for recovery actions

- Flooding rate dependent on

- Pumping capacity, size of pipe, presence of restricting orifices

- Flood rate allocation method presented in NSAC-60, 1984

- Large, medium, and small 


\section{Flood Rate Allocation}

NSAC-60, 1984

- Total flood frequency allocated to:

- Large flood (10\%)

- Medium flood (30\%)

- Small flood (60\%)

- Flood Rate

- Large flood = maximum rate

- Medium flood $=(\max$ rate $) / 3$

- Small flood $=(\max$ rate $) / 6$ 


\section{More Recent Estimates from EPRI}

- Pipe Rupture Frequencies for Internal Flooding PRAs, Revision 1. EPRI, Palo Alto, CA: 2006. (EPRI-1013141)

- Rates per Reactor Operating Year

- By Plant system, pipe diameter, and flood mode

- Spray (<100 gpm)

- Flood (100 gpm to 2,000 gpm)

- Major Flood (>2,000 gpm) 


\section{Flood Scenarios Defined}

- Flood scenarios depend on:

- Flood source

- Area layout

- Flood growth and propagation

- Flood rate, drainage, free area for flooding, critical height of flood (time to fill volume)

- Different equipment targets can produce different critical heights

- Spray and splashing should also be considered

- Time available for recovery 


\section{Quantifying Flood Core Damage Freq.}

- For each flood scenario:

- Flood frequency

- Fail to recover probability

- Flood propagation probability

- Failure of any flood barriers

- No credit for failed barriers

- Set of equipment failed by flood

- Internal events PRA model modified to calculate conditional core damage probability

- Flood scenario frequency (first 3 items) combined with CCDP to calculate flood core damage frequency 


\section{Flood Scenarios can also be added to PRA Model}

- Internal Events PRA model expanded to include flood scenarios

- Equipment (basic events) transformation to flood scenarios

- E.g., DG-A = DG-A + FLD-Z1 


\section{Original Fault Tree for ECS Train A}

Transform DG-A basic event to include failure caused by flood in zone-1
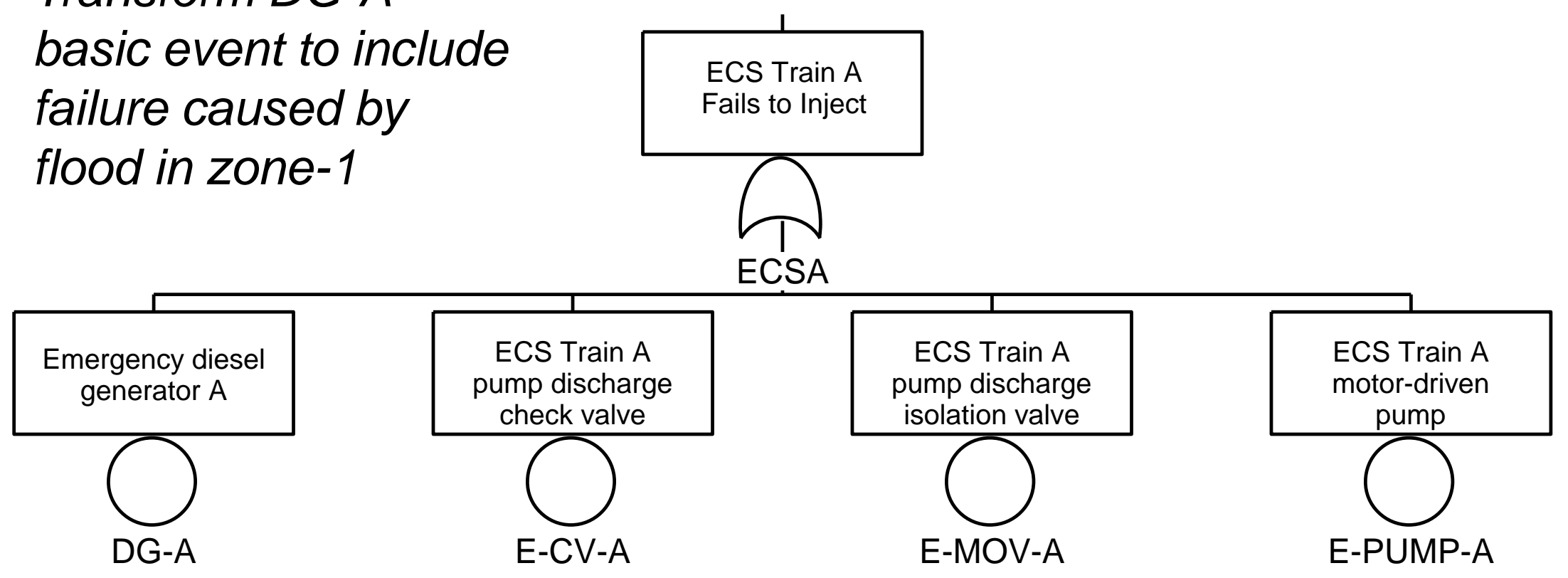


\section{DG-A Transformed to Include failure caused by Flood Scenario-1}

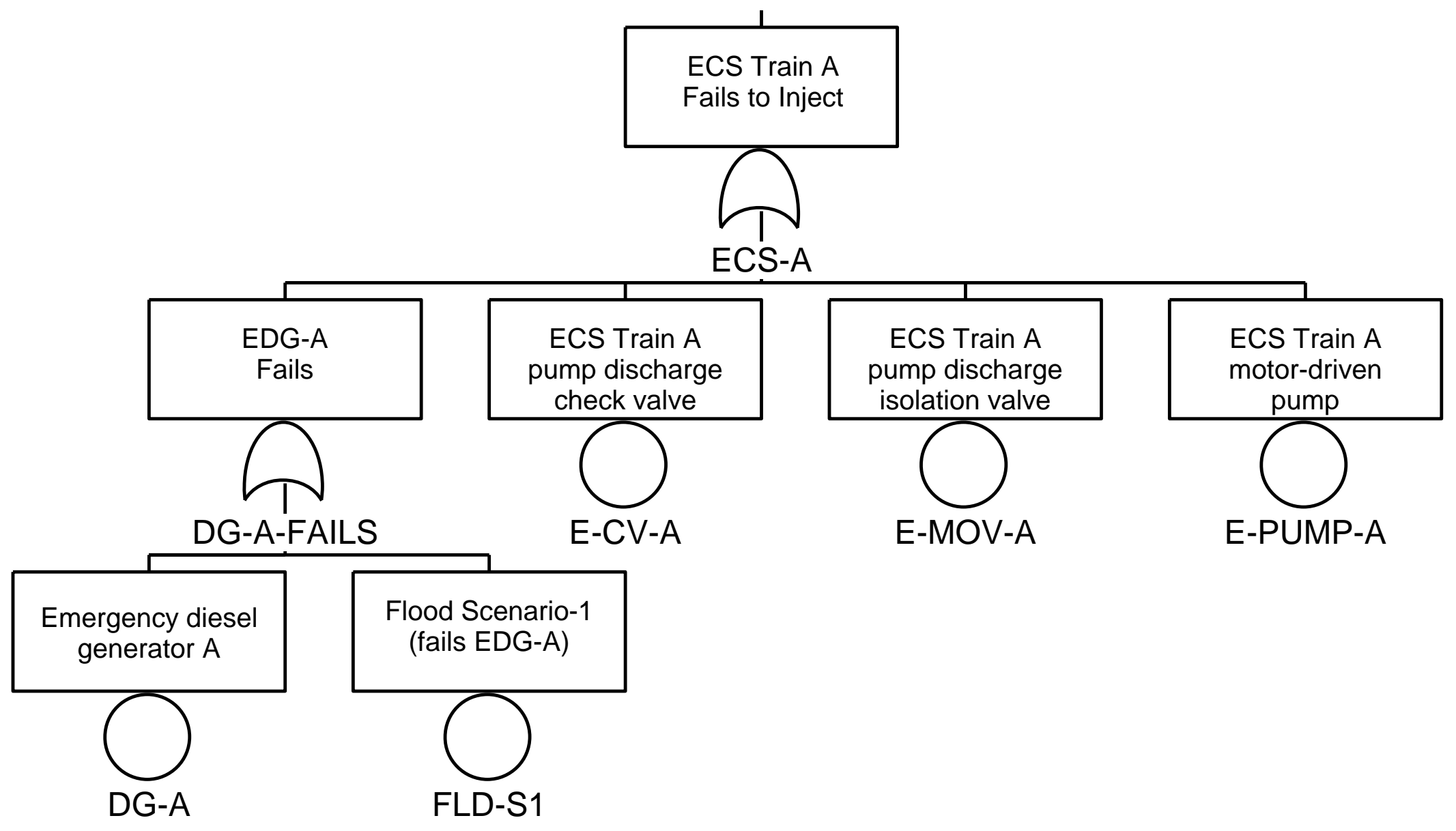




\section{Flood Scenario Frequency Refined}

- For each Flood Scenario:

- Recovery (isolation of rupture) probability

- More realistic estimates of

- Flood propagation (from one location to another)

- Equipment fragility

- Continue refining until

- Scenario no longer significant contributor to risk, or

- Realistic estimate of risk contribution 


\section{Few Plants Identified Internal Flooding Vulnerabilities via IPE}

- Propagation of flood to adjacent areas (doors swing outward) fails safeguards equipment

- Failure of circulating water expansion joints

- Rupture of service water or circulating water systems result in flooding of turbine building

- Rupture of demineralized water line results in flood of relay and switchgear rooms

- However, 17 plants identified internal flood related plant improvements 


\section{References}

- INEL Report EGG-SSRE-9639

- $\quad$ EPRI TR-100380

- $\quad$ EPRI 1012302

- EPRI-1013141

- NSAC-60, 1984

- IAEA TECDOC-478 (Reliability Database, 1988)

- $\quad$ EPRI-1013141

- Elemental Basic Method

- Elemental Thomas Method

- $\quad$ Stress and Strain Analysis (e.g. pc-PRAISE Computer Code)

- Integrated Approach 


\section{SAPHIRE EXAMPLE}

- NSW TRAIN A RUPTURES = 1.E-3/YR

- SET NSW PUMP 1, 3, AND 5 TO FAIL (TRUE) 


\section{Elemental Basic Method}

- $200 \mathrm{ft}$ Non-PCS piping: Failure rate $=1.2 \mathrm{E}-10 / \mathrm{ft}-\mathrm{hr}$

- 10 Valves: Failure rate $=4 \mathrm{E}-10 /$ valve-hr

- 3 Pumps: Failure rate $=1.2 \mathrm{E}-9 /$ pump-hr

- 20 Flanges: Failure rate =1.E-10/flange-hr

- 2 Heat Exchanger: Failure rate = 4.E-9/htx-hr

- $1 \mathrm{yr}=8760 \mathrm{hrs}$

- Average flow rate from rupture $=3000 \mathrm{gpm}$

- Average drain rate $=1500 \mathrm{gpm}$

- Floor area $=3000 \mathrm{sq}-\mathrm{ft}$

- Pump pedestal $1 \mathrm{ft}$

Calculate total failure rate and time available to react. 


\section{Elemental Basic Method - Calculation}




\section{Elemental Basic Method - Calculation}

\begin{tabular}{|l|r|c|c|}
\hline $\begin{array}{c}\text { COMPONENT } \\
\text { TYPE }\end{array}$ & $\begin{array}{c}\text { FAILURE } \\
\text { RATE/HR }\end{array}$ & UNITS & FREQ/YR \\
\hline pipe (ft) & $1.20 \mathrm{E}-10$ & 200 & $2.10 \mathrm{E}-04$ \\
\hline valves & $4.00 \mathrm{E}-10$ & 10 & $3.50 \mathrm{E}-05$ \\
\hline pumps & $1.20 \mathrm{E}-09$ & 3 & $3.15 \mathrm{E}-05$ \\
\hline flages & $1.00 \mathrm{E}-10$ & 20 & $1.75 \mathrm{E}-05$ \\
\hline hx & $4.00 \mathrm{E}-09$ & 2 & $7.01 \mathrm{E}-05$ \\
\hline & & & $3.64 \mathrm{E}-04$ \\
\hline & height & g/cuft & gals \\
\hline sqft & 1 & 7.48 & 22440 \\
\hline 3000 & & gpm & mins \\
\hline & Leakage rate & 3000 & 15 \\
\hline & accu rate & 1500 & \\
\hline
\end{tabular}




\section{High Winds, External Flood, and Other (HFO)}




\section{Learning Objectives}

- After studying this section you should know:

- Steps in the progressive screening approach for other external events

- Comparison to Standard Review Plan (SRP) [NUREG-0800]

- Examples of nonconformance to SRP criteria for high winds, external floods, transportation accidents, and nearby facility accidents, and the analysis method(s) used to address these external hazards. 


\section{Overview}

- HFO events considered in the IPEEE:

- High Winds

- External Floods

- Transportation Accident

- Nearby Facility Accident

- "Other" External Events

- Progressive screening approach

- Does NOT include Internal Flood, Internal Fire or Seismic, which were addressed specifically 


\section{Recommended IPEEE Approach for Winds, Floods, and Others}

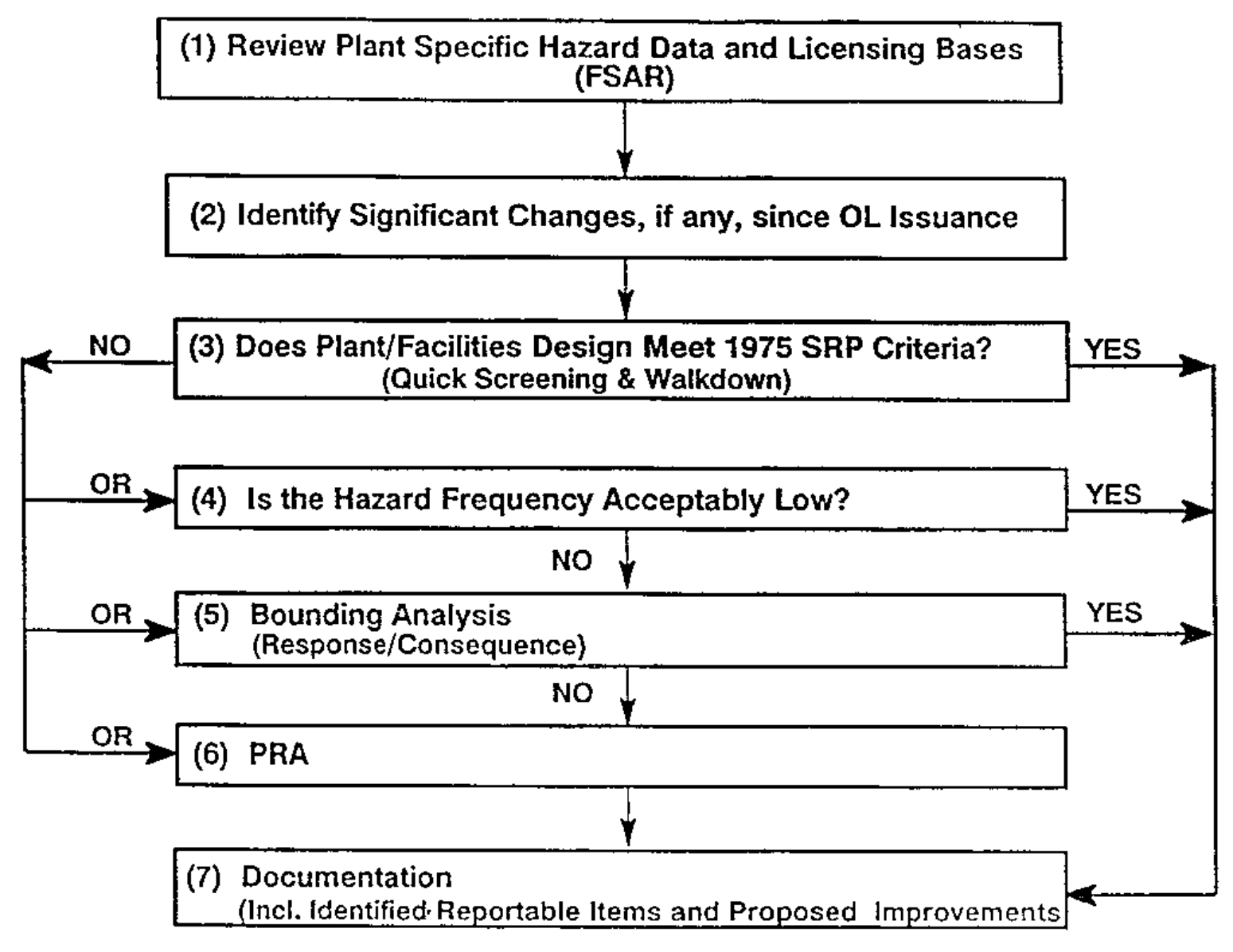

Figure 5.1 Recommended IPEEE Approach for Winds, Floods, and Others 


\section{Procedure for Progressive Screening of Other External Events}

Series of analyses in increasing level of detail, effort, and resolution.

1. Review plant design hazard, the licensing bases, and the resolution of each hazard event (FSAR and SER).

2. Identify significant changes at the site and surrounding, if any, since the issuance of $\mathrm{OL}$, with respect to:

- Military and industrial facilities within 5 miles of the site.

- Onsite storage or other activities involving hazardous materials.

- Transportation.

- Development that could affect the original design conditions.

3. Perform a confirmatory walkdown of the plant.

4. Determine if the plant and facilities design meet the SRP criteria (if yes, then no further analysis is necessary) 


\section{Procedure for Progressive Screening of Other External Events (continued)}

- If plant and facilities design do not meet SRP criteria for an external hazard, optional steps include:

- Determine if the hazard frequency is acceptably low (less than 1E5 per year).

5. Perform a bounding analysis.

- Bounding analysis criteria:

- Hazard would not result in core damage.

- CDF (conservatively estimated) is below $1 \mathrm{E}-6$ per year.

6. Perform a PRA.

- PRA criterion:

- CDF is below 1E-6 per year. 


\section{Potential External Events to be Considered}

- Aircraft Impact

- Avalanche

- Biological Events

- Coastal Erosion

- Dam Failure

- Drought

- External Flooding

- Extreme Winds and Tornadoes

- Fog

- Forest Fire
- Frost

- Hail

- High Tide, High Lake level or High River Stage

- High Summer Temperature

- Hurricane

- Ice Cover

- Industrial or Military Facility Accident

- Intense Precipitation 


\section{Potential External Events to be Considered}

- Landslide

- Lightning

- Low Lake or River Stage

- Low Winter Temperature

- Meteorite

- Release of Chemicals from On-site Storage

- River Diversion

- Sand Storm

- Seiche
- Seismic Event

- Snow

- Soil Shrink/Swell

- Storm Surge

- Transportation Accidents

- Tsunami

- Toxic Gas

- Turbine Generated Missiles

- Volcanic Activity

- Waves 


\section{Initial Screening of Events}

- From NUREG/CR-2300, Section 10.3.1

(A Guide to the Performance of Probabilistic Risk Assessments for Nuclear Power Plants)

- The event is of equal or lesser damage potential than the events for which the plant has been designed.

- The event has a significantly lower mean frequency of occurrence than other events with similar uncertainties and could not result in worse consequences than those events

- The event cannot occur close enough to the plant to affect it.

- The event is included in the definition of other event

- The event is slow in developing and there is sufficient time to eliminate the source of the threat or to provide an adequate response. 


\section{Initial Screening of Events}

- Screening Criteria defined in NUREG/CR-2300 Section 10.3.1.

1 - Less than plant design basis,

2 - Event is bounded (I.e., lower frequency and consequences) by another event,

3 - Event cannot occur close enough to the plant to be a problem, 4 - Event is included in the definition of another event. 


\section{Example Initial Screening}

Event

Aircraft Impact

Dam Failure

Forest Fire

Lightning

Meteorite

Sand Storm
Screening

Criteria

----

4

3

1

2

3
Remarks

Bounding analysis

Included in external flooding analysis

There are no forests in the vicinity; site is cleared

All buildings protected

Small frequency

Not relevant for the region 


\section{Initial Screening Exercise}

- For NPP Location near Denver, Colorado a plant is designed to meet DBE criteria. Which of the following events can be screened out using SRP screening criteria

- Tsunami

- Avalanche

- Volcano

- Tornado

- Sand Storm

- Lightning

- Heavy Snow 


\section{Typical Events for Bounding Analysis (\#2)}

- Aircraft Impact

- External Flooding

- Extreme Winds and Tornadoes

- Industrial or Military Facility Accidents

- Release of Chemicals from On-site Storage

- Transportation Accidents

- Turbine Generated Missiles 


\section{Typical Events for Screening Criteria \#3}

- Volcano

- Dust storm

- Tsunami

- Forest (External) Fire

- Meteorite

- Seiche 


\section{Typical Events for Screening Criteria \#4}

- Extreme Winds and Tornadoes

- Dam Failure

- Heavy Precipitation

- Forest (External) Fire

- Fog 


\section{Tornado and High Wind Events}




\section{Destruction from Wind or Tornado}

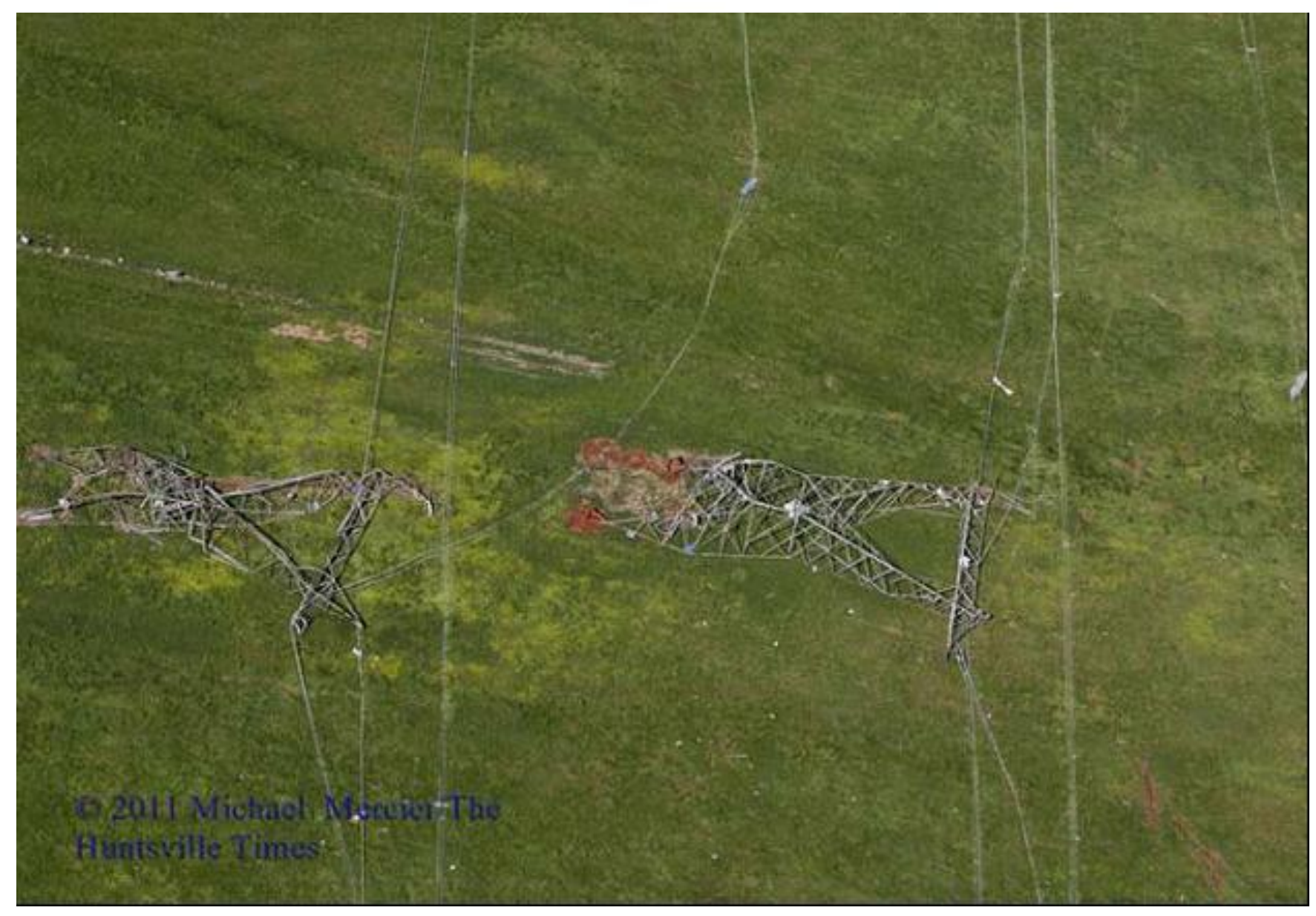




\section{Destruction from Wind or Tornado}

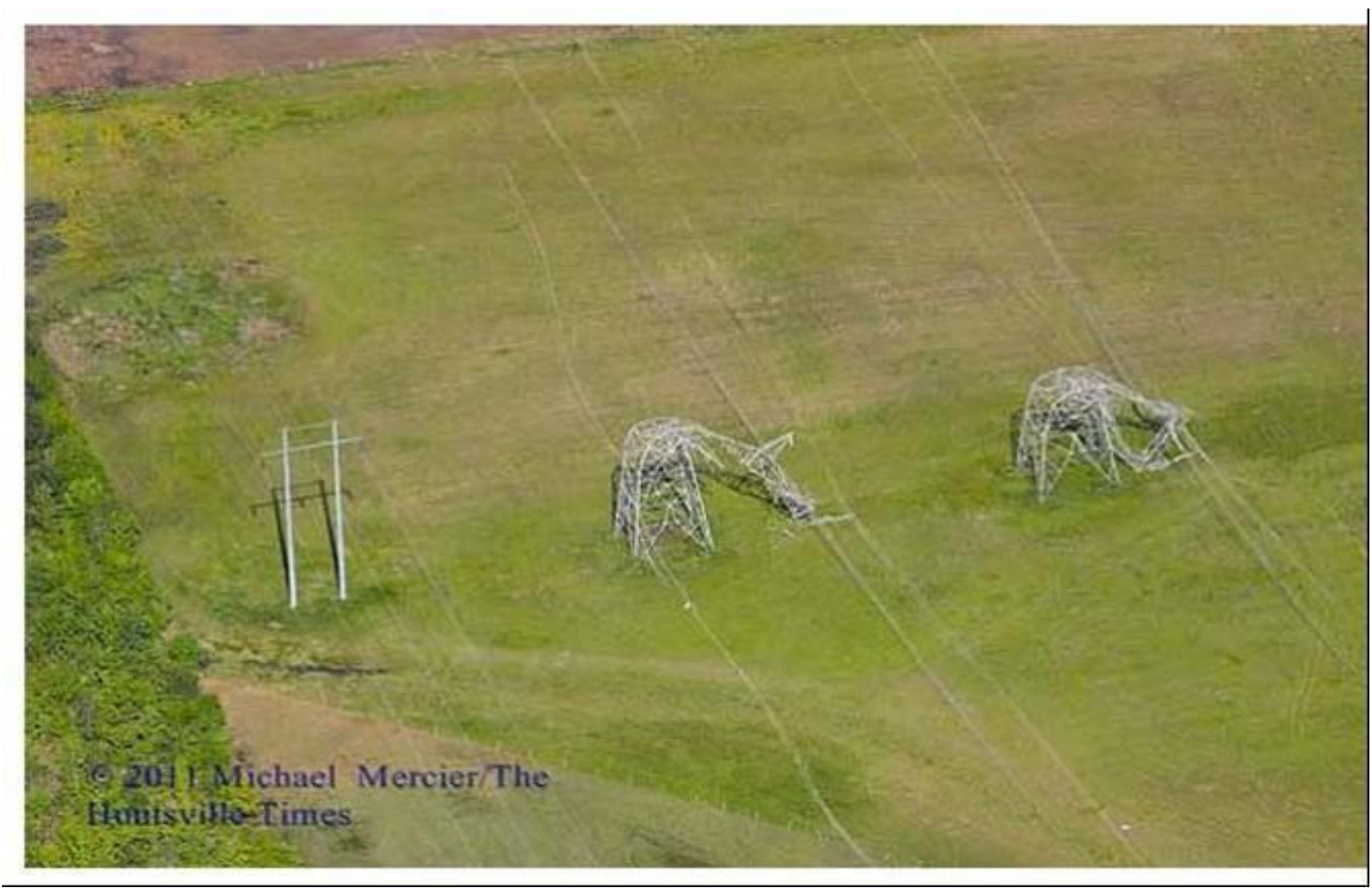




\section{Destruction from Wind or Tornado}

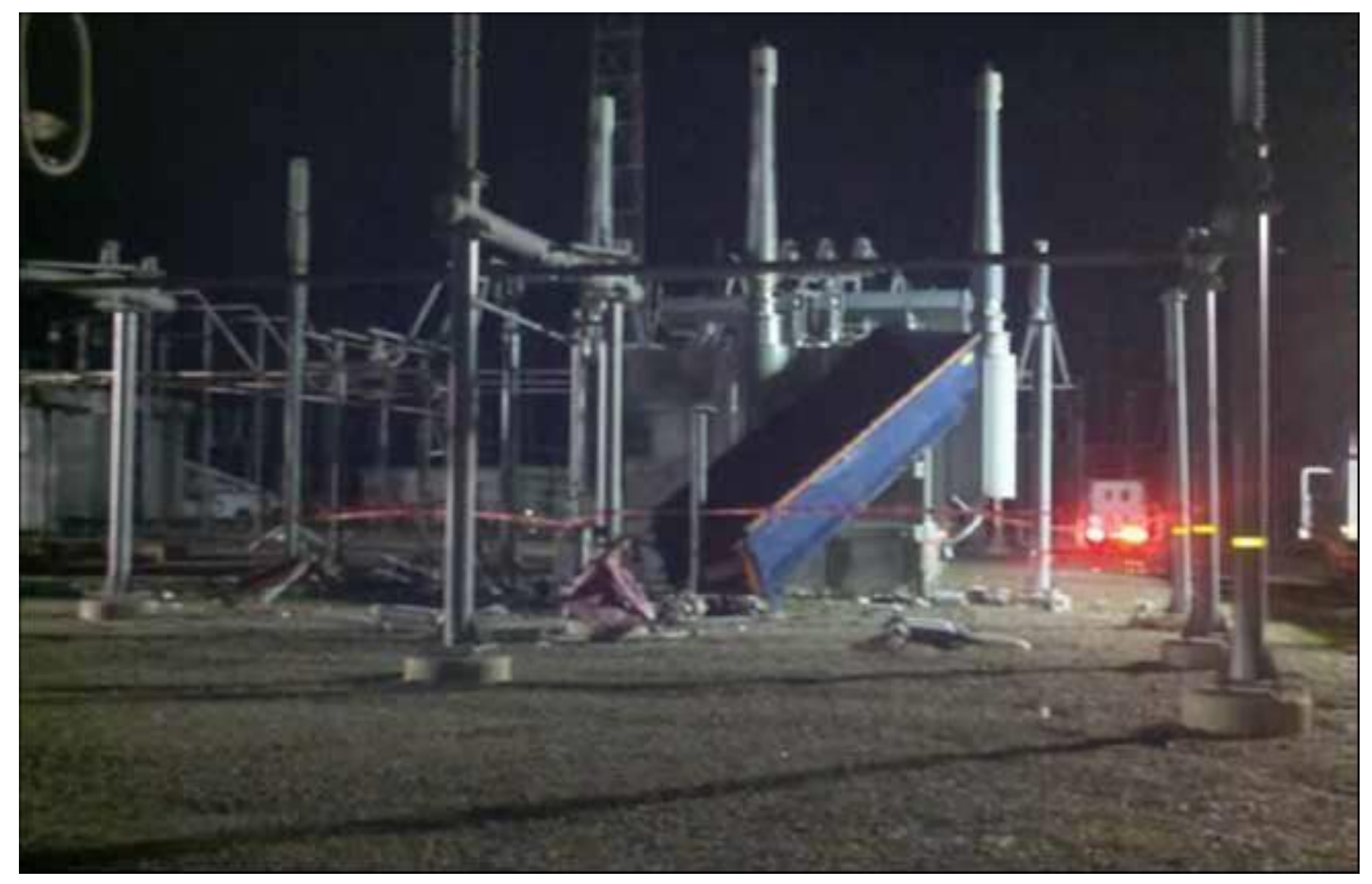




\section{Destruction from Wind or Tornado}

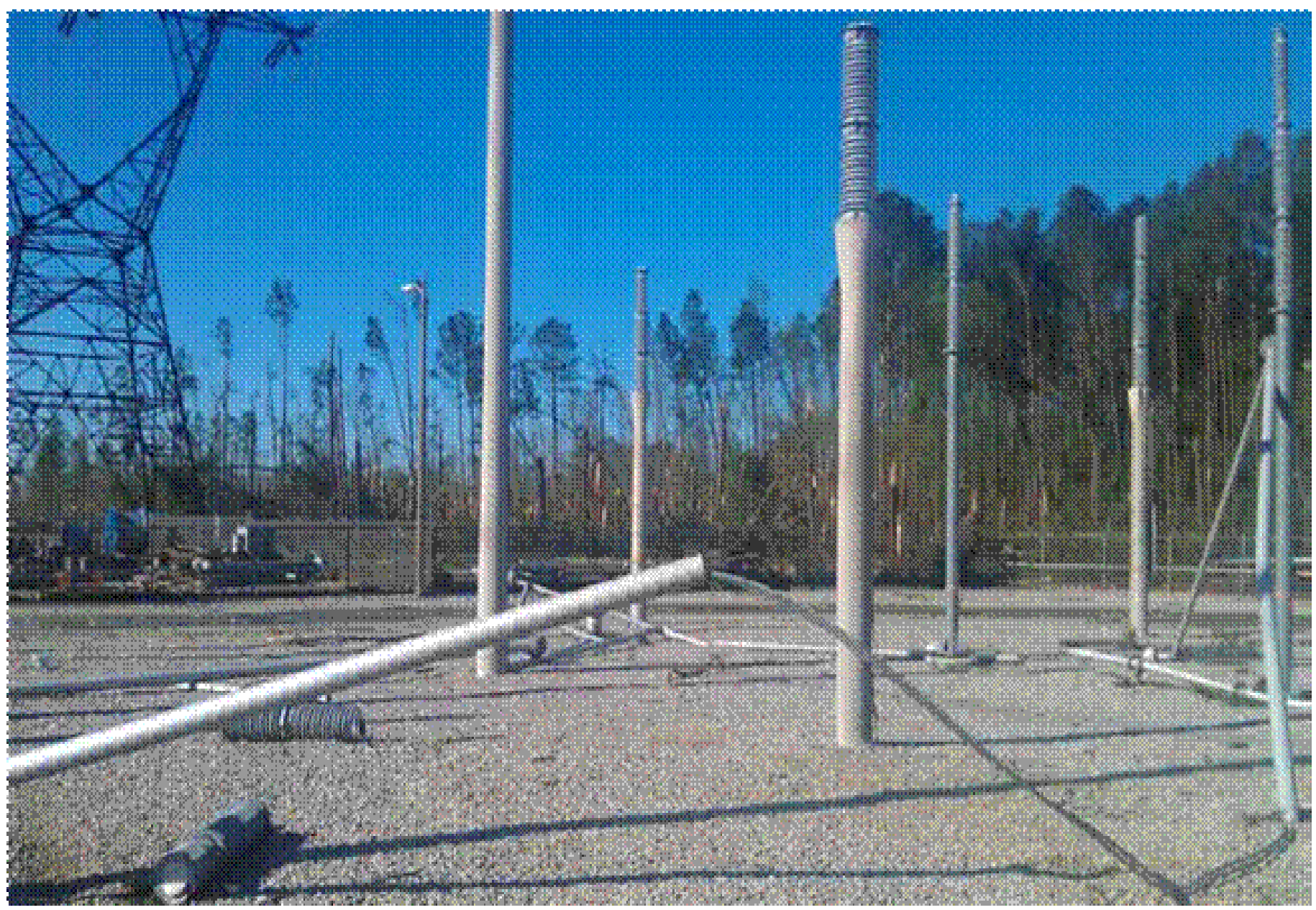




\section{Tornado Intensity Distribution}

\begin{tabular}{|c|c|c|c|c|c|c|}
\hline Intensity & F0 & F1 & F2 & F3 & F4 & F5 \\
\hline Number & 17554 & 16076 & 9145 & 2903 & 1005 & 130 \\
\hline $\begin{array}{c}\text { Ave. } \\
\text { Length } \\
\text { (mi) }\end{array}$ & 1.14 & 3.376 & 6.633 & 10.495 & 13.442 & 14.945 \\
\hline $\begin{array}{c}\text { Ave. } \\
\text { Width } \\
\text { (ft) }\end{array}$ & 119.9 & 241.3 & 442.4 & 872.6 & 1426.8 & 1581.0 \\
\hline $\begin{array}{c}\text { Ave. } \\
\text { Area } \\
\text { (mi }{ }^{2} \text { ) }\end{array}$ & 0.0458 & 0.2220 & 0.7366 & 2.1059 & 3.7797 & 4.6410 \\
\hline
\end{tabular}

Data is from NUREG/CR-4461, Rev. 2, Tornado Climatology of the Contiguous United States, February 2007, for contiguous United States $\left(3,020,000 \mathrm{mi}^{2}\right)$, and spans beginning of 1950 to the end of August 2003 (53.67 years) 


\section{Fujita Tornado F Scale Wind Speeds}

\begin{tabular}{|l|l|l|l|l|}
\hline Intensity & Description & $\begin{array}{l}\text { Orig. F-Scale } \\
\text { (Fastest 1/4 } \\
\text { mile, mph) }\end{array}$ & $\begin{array}{l}\text { Fujita Scale } \\
(3-s \text { gust, } \\
\text { mph) }\end{array}$ & $\begin{array}{l}\text { Operational } \\
\text { Enhanced Fujita } \\
\text { Scale (3-s gust, mph) }\end{array}$ \\
\hline F0 & Light Damage & $40-72$ & $45-78$ & $65-85$ \\
\hline F1 & $\begin{array}{l}\text { Moderate } \\
\text { Damage }\end{array}$ & $73-112$ & $79-117$ & $86-110$ \\
\hline F2 & $\begin{array}{l}\text { Considerable } \\
\text { Damage }\end{array}$ & $113-157$ & $118-161$ & $111-135$ \\
\hline F3 & $\begin{array}{l}\text { Severe } \\
\text { Damage }\end{array}$ & $158-206$ & $162-209$ & $136-165$ \\
\hline F4 & $\begin{array}{l}\text { Devastating } \\
\text { Damage }\end{array}$ & $207-260$ & $210-261$ & $166-200$ \\
\hline F5 & $\begin{array}{l}\text { Incredible } \\
\text { Damage }\end{array}$ & $261-318$ & $262-317$ & $>200$ \\
\hline
\end{tabular}




\section{High Winds/Tornadoes}

- NRC Regulatory Requirements:

- 10 CFR Part 50 Appendix A Criterion 2 and Criterion 4, 10 CFR Part 100.10

- Other Related Documents:

- Regulatory Guide 1.13 (Spent Fuel Pool), 1.76, 1.117

- SRP (1975) No. 3.3.1, 3.3.2, 3.5.1.4, 3.5.1.5, 3.5.2, 3.5.3

- ASCE Paper 3269, "Wind Forces on Structures," Transactions of the American Society of Civil Engineers, Vol. 126, Part II, 1961

- ANSI A58.1 Building Code Requirements for Minimum Design Loads in Buildings and Other Structures, American National Standards Institute Committee A58.1-1972 


\section{Examples of Nonconformance to SRP Criteria}

- Maximum wind speed considered in plant design was less than the design basis tornado specified in Regulatory Guide 1.76.

- Design basis tornado missile spectrum differs from that specified in SRP.

- Structure not designed to withstand tornado wind or missile impact. 


\section{Wind Hazard Frequency}

- Wind loading due to tornado is limiting.

- Tornado wind annual exceedence frequency:

$$
\phi_{\mathrm{v}}=\phi_{\mathrm{t}} \bullet \phi_{\mathrm{v} \mid \mathrm{t}}
$$

where

$\phi_{\mathrm{v}}=$ annual frequency of a tornado striking the plant with a wind speed $>$ v.

$\phi_{\mathrm{t}}=$ the annual frequency of a tornado striking the plant.

$\phi_{\mathrm{v} \mid \mathrm{t}}=$ the conditional probability of tornado intensity or fraction of tornadoes with peak wind speed $>v$. 


\section{Frequency of Tornado Striking the Plant $\left(\phi_{t}\right)$}

- Two models for estimating the tornado strike frequency:

- Point Target Model

- Large (aka Aerial) Target Model

- Point target model is used if there are no vulnerable structures at the site with dimensions on the order of tornado damage width dimensions.

- Point target model tornado strike frequency:

$-\phi_{\mathrm{tp}}=\mathrm{n} \bullet\left(\mathrm{A}_{\mathrm{tp}} / \mathrm{A}\right)$

$-\mathrm{n}=$ the mean number of tornado occurrences per year in the reference area.

- $A_{t p}=$ the mean path area of tornado.

- $A=$ the reference area where the plant is located and over which tornado data are accumulated. 


\section{Frequency of Tornado Striking the Plant, $\phi_{t}$ (continued)}

- Large target model tornado strike frequency:

$-\phi_{t p}=n \bullet\left(A_{t p} / A\right)$

- $A_{t}$ calculated considering footprint of plant, damage area of a typical tornado (width and travel length), and angle of tornado approach

- See next slide

- Alternate method (NUREG/CR-4461, Rev. 2)

- $A_{\text {tp }}=W_{\text {target }} \times L_{\text {tornado }}$

Where:

$$
\begin{aligned}
& \mathrm{w}_{\text {target }}=\text { dimension of target } \\
& \mathrm{L}_{\text {tornado }}=\text { path length of tornado }
\end{aligned}
$$




\section{Tornado Strike Area Calculation}

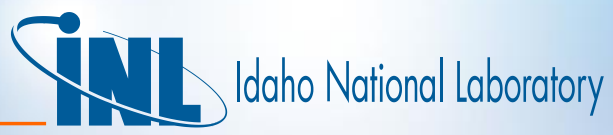

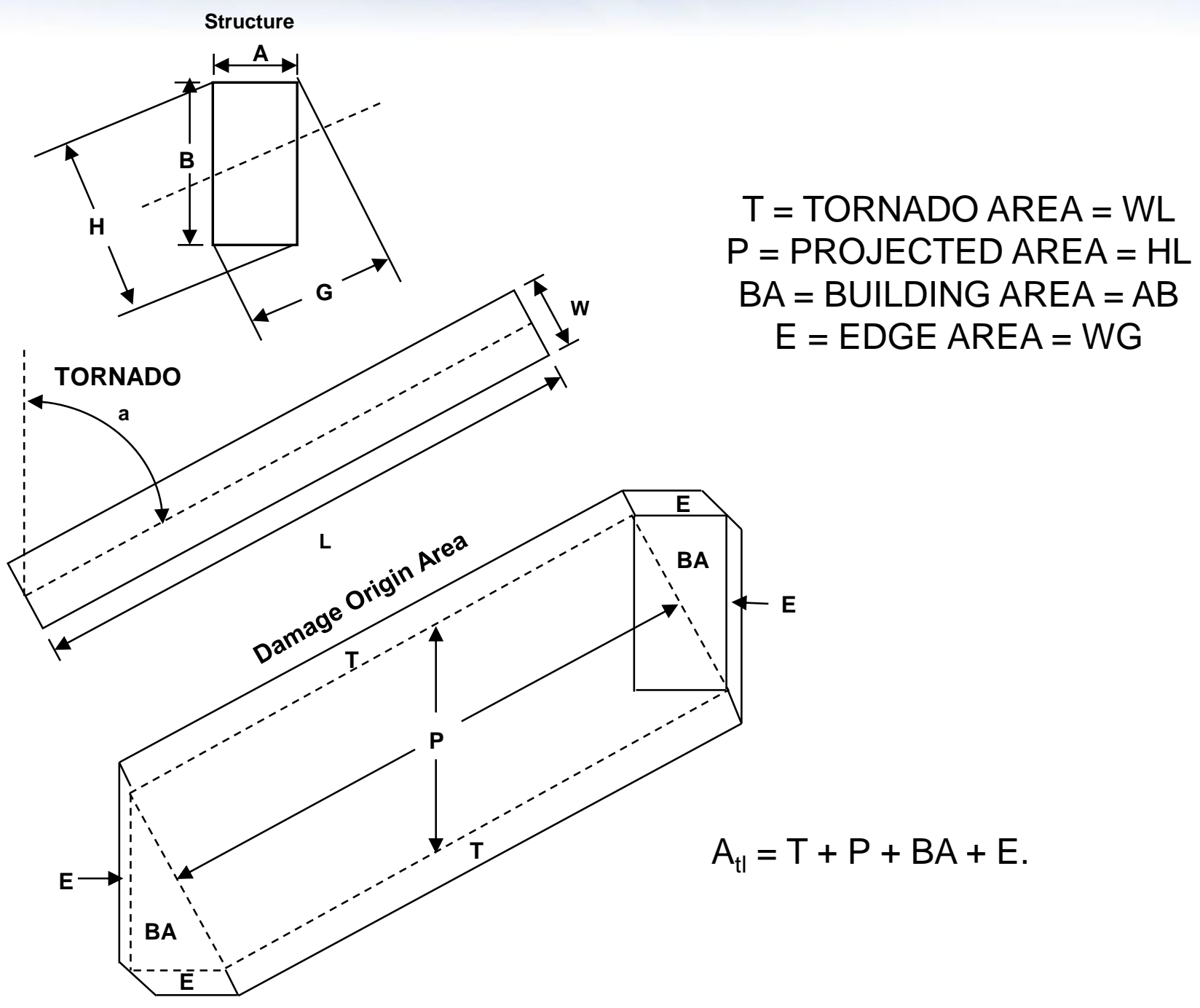




\section{Examples from the IPEEEs}




\section{Tornado Origin Area $\left(A_{0}=A_{t}\right)$ for the Hatch Site}

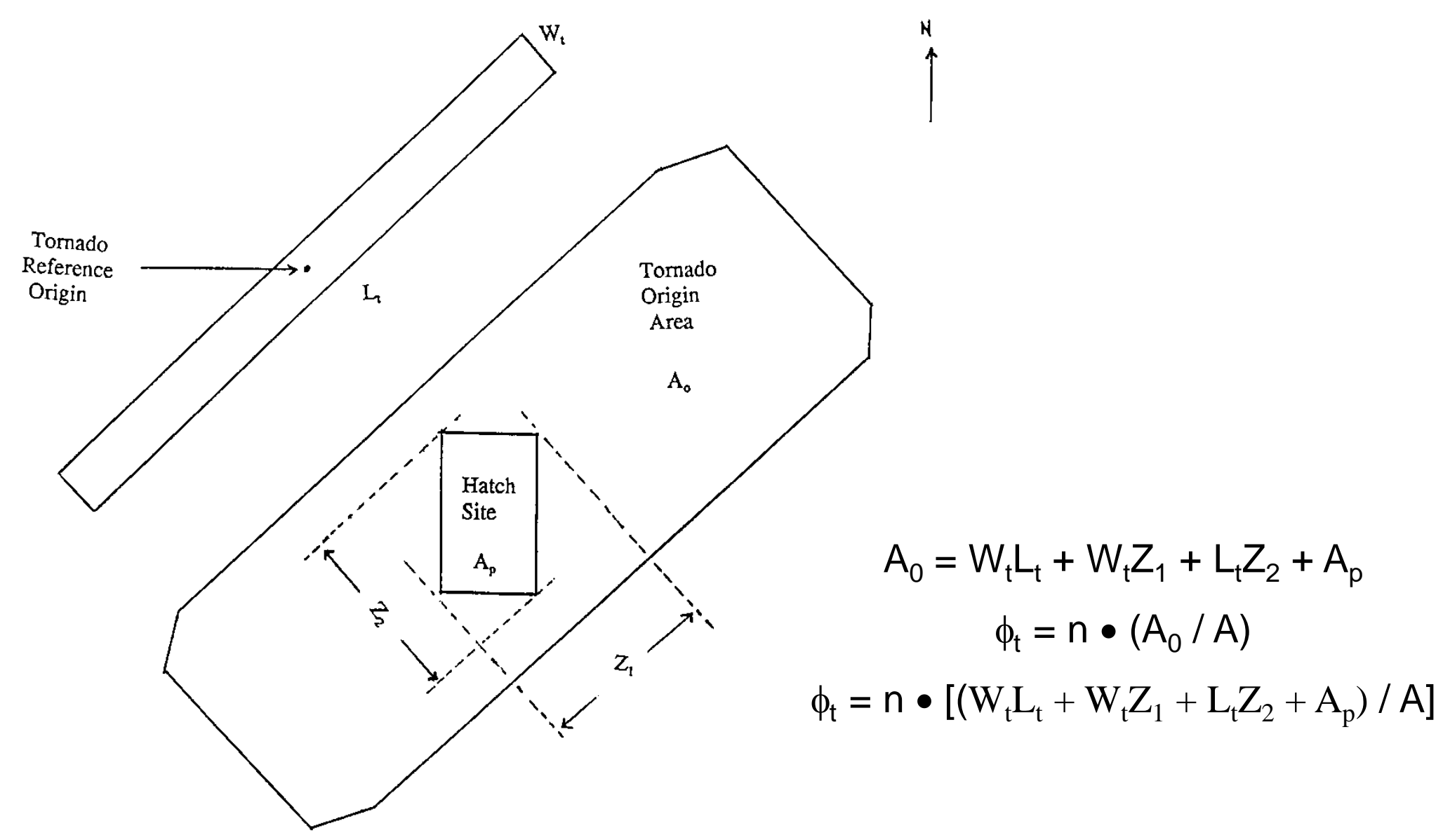




\section{Tornado Model Comparisons}

- From Plant IPEEE (1996):

- Site is represented by a rectangular area of length, $2000 \mathrm{ft}(.38 \mathrm{mi})$ in the N-S direction, and width, $1100 \mathrm{ft}$. $(.21 \mathrm{mi})$

- For this analysis, it is conservatively assumed that the projections on the tornado length $(\mathrm{Z1})$ and width (Z2) has the maximum possible value of $2280 \mathrm{ft}(.43 \mathrm{mi})=\operatorname{Sqrt}\left(2000^{\wedge} 2+1100^{\wedge} 2\right)$.

- Tornado data from National Severe Storm Forecast: 55 tornados occurred in 38 years (Aug. 1954 - Jan. 1993) in a 36-mi radius of the Site.

- Tornado Ave. path length (L) is $2.17 \mathrm{mi}$, ave. path width $(\mathrm{W})$ is $0.051 \mathrm{mi}(270 \mathrm{ft})$

- the reference area (within 36-mi radius) $=4070$ sq. mi.

Calculate Tornado Strike probability using Point Target Model and Large target Model 


\section{Example calculation}




\section{Tornado Model Comparisons}

$\mathrm{N}=55 / 38=1.45$ tornado $/ \mathrm{yr}$

A $($ Tor Strike Area $)=3.14{ }^{*} 36^{\wedge} 2=4070$ sq. mi.

Point Target Model

$A_{P}=0.43 * 2.17=0.933$ sq. mi.

Tornado Strike Prob $=1.45 * 0.933 / 4070=3.3 E-4 / y r$

Large Target Model

$$
\begin{aligned}
A_{0} & =L_{t} W_{t}+L_{t} Z_{1}+W_{t} Z_{1}+A_{P} \\
& =2.17^{*} 0.051+2.17^{*} 0.43+0.051^{*} 0.43+0.38^{*} 0.21 \\
& =1.15 \text { sq. mi. }
\end{aligned}
$$

Tornado Strike Prob $=1.45^{\star} 1.15 / 4070=4.1 \mathrm{E}-04 / \mathrm{yr}$ 


\section{Tornado Strike Frequency at the Second Site}

- Based on 94 tornadoes during a 42-year history (1950-1992) within 36 miles of site.

- Average tornado path length is 4.24 miles and average tornado path width is 0.066 mile. (Estimated $A_{P}=1.56$ sq. mi.)

- Reference area is 4,070 square miles.

- Tornado strike frequency at the site is 8.57E-04 per year. 


\section{Diagram of Tornado Origins $\left(A_{s}=A_{t p}\right)$}

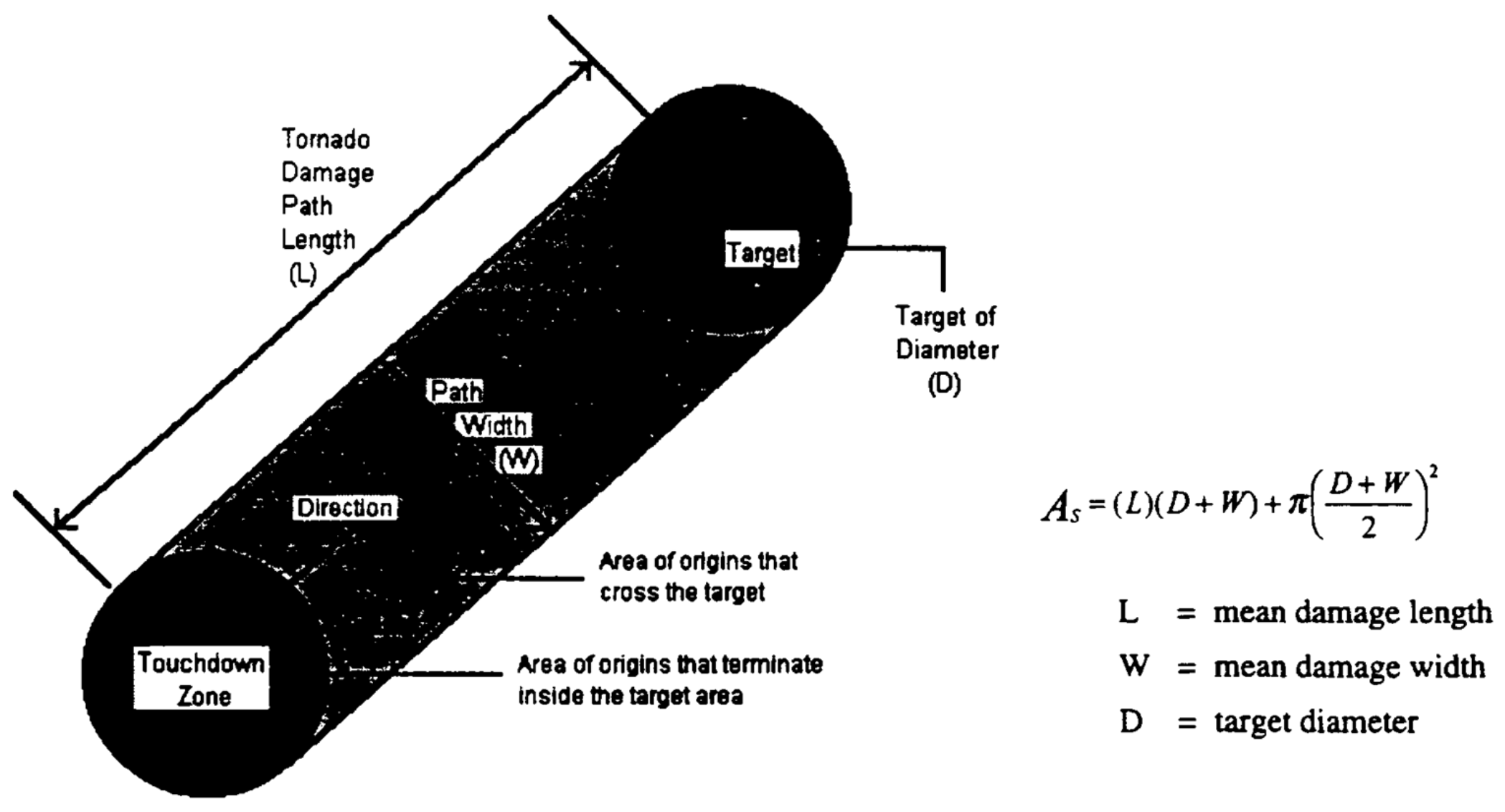




\section{Example of Tornado Missile Analysis Using TORMIS}




\section{Tornado Missile Impact Frequency}

- Dependent on tornado strike frequency $\phi t$ and probability of tornadogenerated missile hitting a plant structure.

- Methods of estimating tornado missile impact frequency:

- Tornado Missile Risk Analysis Model (TORMIS) computer code.

- Generic results from TORMIS calculations for hypothetical plants [EPRI NP-768, -769].

- Other computer programs; e.g., SPRPND by Bechtel used in the Palo Verde IPEEE.

- Study approach postulates a spectrum of available missiles and evaluates potential damage to plant structures. 


\section{TORMIS Analysis Plant Site Model}

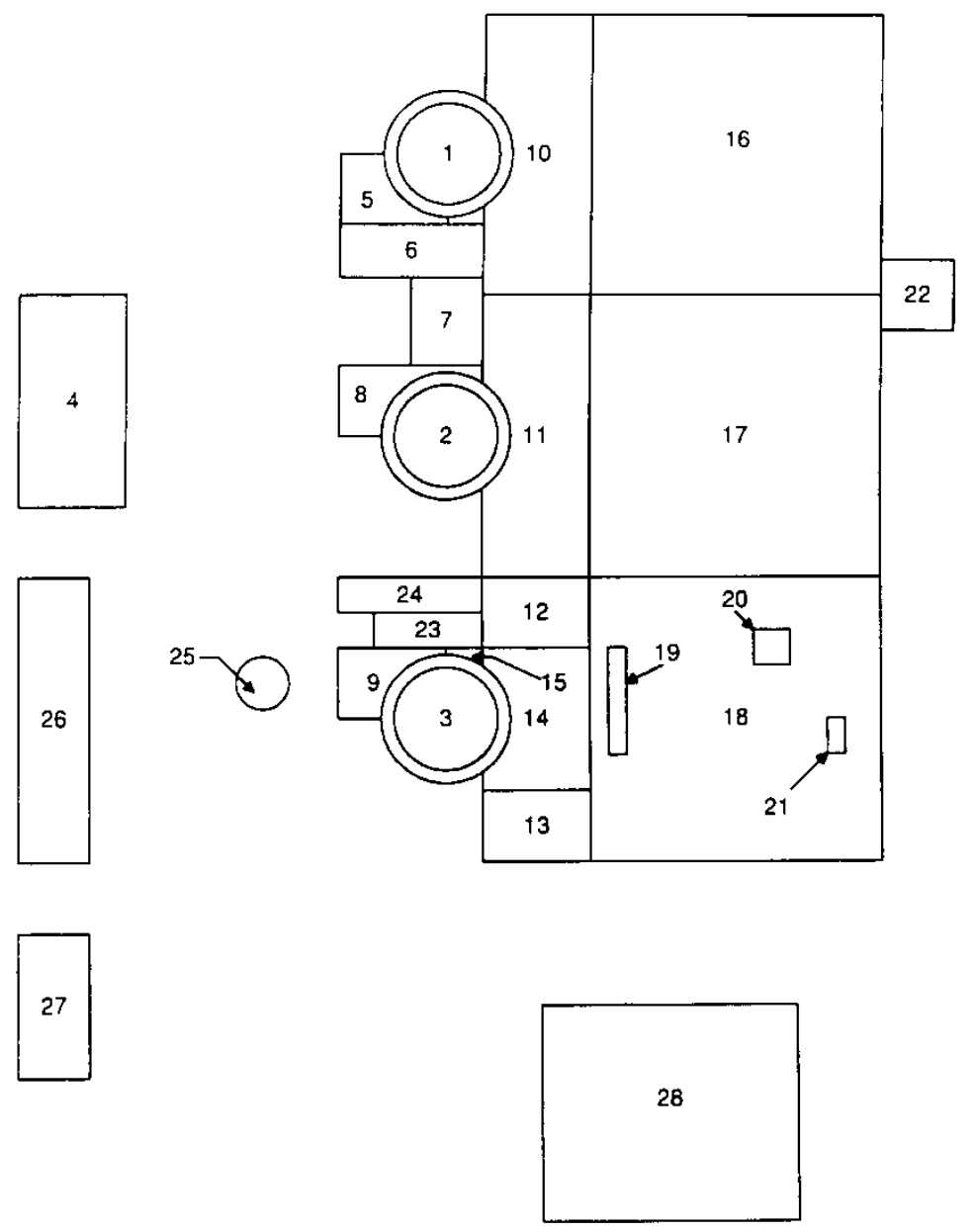




\section{TORMIS Analysis Plant Site Model (continued)}

\begin{tabular}{cl}
\hline Target Number & \multicolumn{1}{c}{ Target Structure } \\
\hline 1. & Unit 1 Reactor Building \\
2. & Unit 2 Reactor Building \\
3. & Unit 3 Reactor Building \\
4. & SSF \\
5. & Unit 1 West Penetration Room \\
6. & Units 1 and 2 Fuel Handling Structure \\
7. & Units 1 and 2 Fuel Pool \\
8. & Unit 2 West Penetration Room \\
9. & Unit 3 West Penetration Room \\
10. & Unit 1 Auxiliary Building \\
11. & Unit 2 Auxiliary Building \\
12. & Unit 3 Auxiliary Building (Control Room Region) \\
13. & Unit 3 Auxiliary Building (Volume beneath U3 East Pen.Room) \\
14. & Unit 3 East Penetration Room \\
\hline
\end{tabular}




\section{TORMIS Analysis Plant Site Model (continued)}

\begin{tabular}{ll}
\hline Target Number & \multicolumn{2}{c}{ Target Structure } \\
\cline { 1 - 2 } 15. & Unit 3 Auxiliary Building (between Control Room and U3 Rx. Bidg.) \\
16. & Unit 1 Turbine Building \\
17. & Unit 2 Turbine Building \\
18. & Unit 3 Turbine Building \\
19. & Unit 3 Upper Surge Tanks \\
20. & Region above Unit 3 EFW motor-driven pumps \\
21. & Region above Unit 3 EFW turbine-driven pump \\
22. & CT-4 Transformer Enclosure \\
23. & Unit 3 Fuel Pool \\
24. & Unit 3 Fuel Handling Structure \\
25. & Unit 3 Borated Water Storage Tank \\
26. & Warehouse \\
27. & Interim Radwaste Facility \\
28. & Radwaste Facility \\
\hline
\end{tabular}




\section{Nuclear Station Missile Origination Zones}

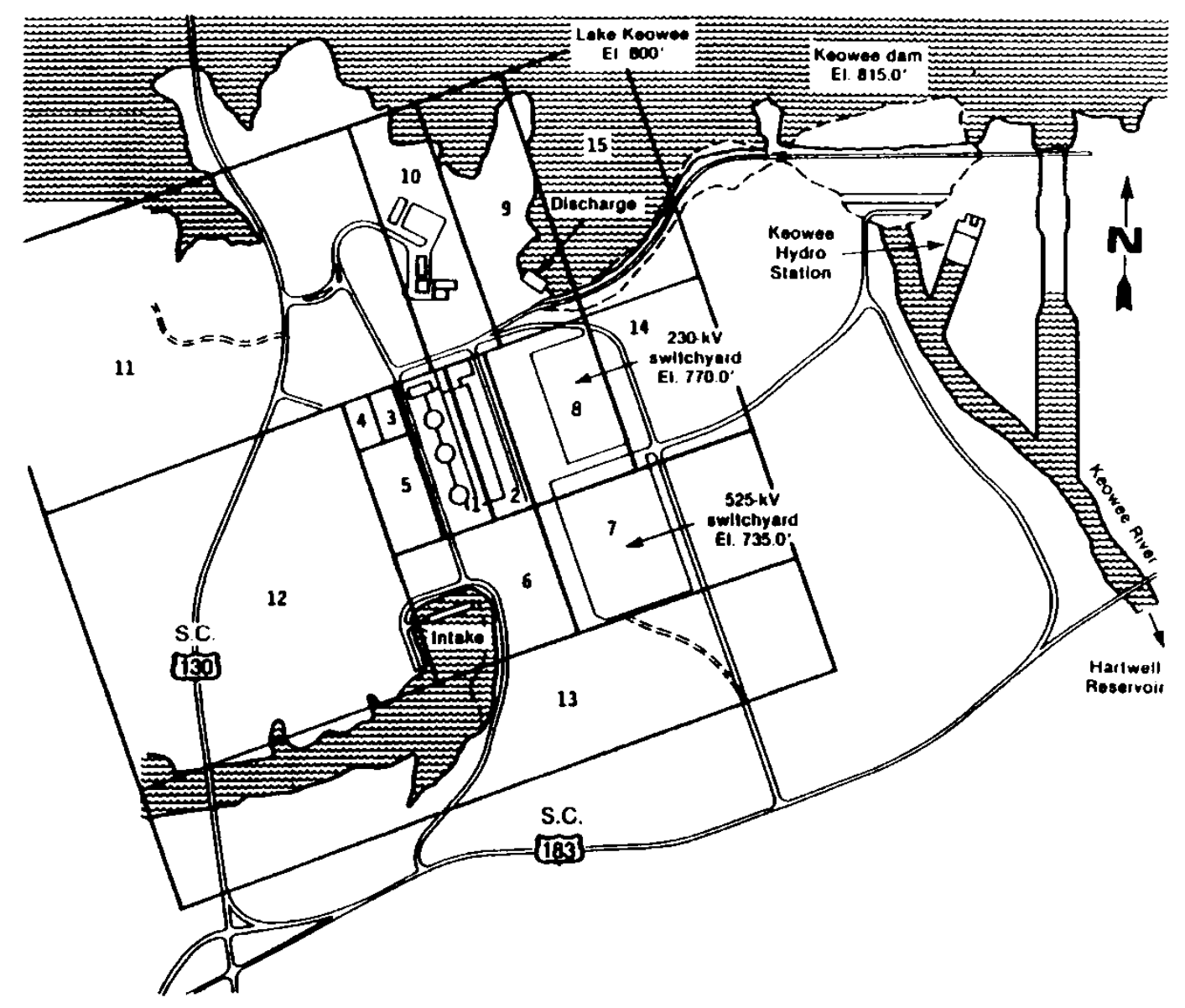




\section{Nuclear Station Missile Distribution}

\begin{tabular}{|c|c|c|c|c|c|c|c|c|c|c|c|c|c|c|c|}
\hline \multirow[b]{2}{*}{ Missiles } & \multicolumn{15}{|c|}{ Missile Zones } \\
\hline & 1 & 2 & 3 & 4 & 5 & 6 & 7 & 8 & 9 & 10 & 11 & 12 & 13 & 14 & 15 \\
\hline Cars & 6 & 24 & 72 & 0 & 490 & 30 & 30 & 15 & 0 & 292 & 100 & 390 & 0 & 25 & 0 \\
\hline Trucks & 0 & 0 & $\mathbf{0}$ & 0 & 0 & 0 & 0 & 0 & 0 & 0 & 0 & 0 & 2 & 0 & 0 \\
\hline Trailers & 9 & 9 & 3 & $\mathbf{0}$ & 6 & 12 & 0 & 0 & 0 & 0 & 0 & 0 & 0 & 0 & 0 \\
\hline Utility Poles & 9 & 7 & 0 & $\mathbf{0}$ & 20 & 0 & 67 & 71 & 0 & 26 & 0 & 0 & 0 & 7 & 0 \\
\hline Barrels & 5 & 0 & 0 & 0 & $\mathbf{0}$ & 0 & 0 & 250 & 0 & 0 & 0 & 0 & 0 & 0 & 0 \\
\hline 1" Rods & $\mathbf{0}$ & 0 & 0 & $\mathbf{0}$ & 25 & 0 & 0 & 10 & $\mathbf{0}$ & $\mathbf{0}$ & $\mathbf{0}$ & 0 & 400 & 400 & 0 \\
\hline Concrete Slabs & 90 & 0 & 0 & 0 & 0 & 0 & 0 & 0 & 0 & 0 & 0 & 0 & 0 & 0 & 0 \\
\hline Small Trees & 0 & 0 & 0 & 1600 & 400 & 0 & 0 & $\mathbf{0}$ & 100 & 130 & 0 & 4000 & 800 & 13000 & 0 \\
\hline Large Trees & $\mathbf{0}$ & 0 & $\mathbf{0}$ & 80 & 0 & 0 & 0 & 0 & $\mathbf{0}$ & 0 & 0 & 100 & 350 & 520 & 0 \\
\hline Wire Reels & 0 & 0 & 0 & 0 & 0 & 0 & 0 & 6 & 0 & 0 & 0 & 0 & 10 & 300 & 0 \\
\hline I-Beam 4" & 0 & 70 & 0 & $\mathbf{0}$ & $\mathbf{0}$ & 0 & 0 & 0 & 00 & 0 & 0 & 0 & 500 & 365 & 0 \\
\hline $8^{\prime}$ & 0 & 0 & 0 & 0 & 0 & 0 & 0 & 50 & $\hat{\mathbf{0}}$ & 100 & 150 & 0 & 500 & 350 & 0 \\
\hline !2" & 0 & 10 & 0 & 0 & 50 & 0 & 0 & 0 & 0 & 0 & 0 & $\hat{v}$ & 200 & 1061 & 0 \\
\hline
\end{tabular}




\section{Examples of Tornado Missile Analysis using TORMIS}




\section{TORMIS Results for Hypothetical Plant}

- Typical result for an operating two-unit plant with tornado frequency of 2.29E-03 per year:

- Frequency that any tornado-generated missile hits the plant structures $(\mathrm{PN})$ is 7.09E-05 per year.

- Frequency that a missile impacts with sufficient force to cause back scabbing if all of the plant structures had 6-in. concrete walls (PL) is $3.45 \mathrm{E}-05$ per year.

- Frequency that a missile impacts with sufficient force to cause back scabbing if all of the plant structures had a 18-in. concrete walls (PU) is 3.33E-06 per year. 


\section{Tornado Impact and Damage Frequencies}

- Scaling down the impact and damage frequencies from EPRI NP-768 with the ratio of the site-specific tornado strike frequency to the another region tornado occurrence frequency:

$-\mathrm{P}^{\mathrm{N}}=2.65 \mathrm{E}-05$ per year - Frequency that any tornado-generated missile will hit plant

$-\mathrm{P}_{\mathrm{L}}=1.29 \mathrm{E}-05$ per year - Frequency of back-scabbing caused by missile impacting a 6 -inch thick wall

$-\mathrm{P}_{\mathrm{U}}=1.25 \mathrm{E}-06$ per year - Frequency of back-scabbing caused by missile impacting a 18-inch thick wall 


\section{Frequency of Tornado Striking the Plant, $\phi_{t}$ (continued)}

- Number of tornado occurrences per year at the site from the Storm Prediction Center, National Weather Service

- Historical tornado data for continental U.S.

- Location specific (longitude and latitude)

- Magnitude specific

- Tornado Climatology of the Contiguous United States - NUREG/CR4461, Rev 2, PNNL-15112, Rev 1., Pacific Northwest National Laboratory - February 2007 


\section{Fujita Tornado F Scale Wind Speeds}

\begin{tabular}{|l|l|l|l|l|}
\hline Intensity & Description & $\begin{array}{l}\text { Orig. F-Scale } \\
\text { (Fastest 1/4 } \\
\text { mile, mph) }\end{array}$ & $\begin{array}{l}\text { Fujita Scale } \\
(3-s \text { gust, } \\
\text { mph) }\end{array}$ & $\begin{array}{l}\text { Operational } \\
\text { Enhanced Fujita } \\
\text { Scale (3-s gust, mph) }\end{array}$ \\
\hline F0 & Light Damage & $40-72$ & $45-78$ & $65-85$ \\
\hline F1 & $\begin{array}{l}\text { Moderate } \\
\text { Damage }\end{array}$ & $73-112$ & $79-117$ & $86-110$ \\
\hline F2 & $\begin{array}{l}\text { Considerable } \\
\text { Damage }\end{array}$ & $113-157$ & $118-161$ & $111-135$ \\
\hline F3 & $\begin{array}{l}\text { Severe } \\
\text { Damage }\end{array}$ & $158-206$ & $162-209$ & $136-165$ \\
\hline F4 & $\begin{array}{l}\text { Devastating } \\
\text { Damage }\end{array}$ & $207-260$ & $210-261$ & $166-200$ \\
\hline F5 & $\begin{array}{l}\text { Incredible } \\
\text { Damage }\end{array}$ & $261-318$ & $262-317$ & $>200$ \\
\hline
\end{tabular}




\section{Tornado Intensity Distribution}

\begin{tabular}{|c|c|c|c|c|c|c|}
\hline Intensity & F0 & F1 & F2 & F3 & F4 & F5 \\
\hline Number & 17554 & 16076 & 9145 & 2903 & 1005 & 130 \\
\hline $\begin{array}{c}\text { Ave. } \\
\text { Length } \\
\text { (mi) }\end{array}$ & 1.14 & 3.376 & 6.633 & 10.495 & 13.442 & 14.945 \\
\hline $\begin{array}{c}\text { Ave. } \\
\text { Width } \\
\text { (ft) }\end{array}$ & 119.9 & 241.3 & 442.4 & 872.6 & 1426.8 & 1581.0 \\
\hline $\begin{array}{c}\text { Ave. } \\
\text { Area } \\
\text { (mi }{ }^{2} \text { ) }\end{array}$ & 0.0458 & 0.2220 & 0.7366 & 2.1059 & 3.7797 & 4.6410 \\
\hline
\end{tabular}

Data is from NUREG/CR-4461, Rev. 2, Tornado Climatology of the Contiguous United States, February 2007, is for contiguous United States $\left(3,020,000 \mathrm{mi}^{2}\right)$, and spans beginning of 1950 to the end of August 2003 (53.67 years) 


\section{Tornado Intensity Distribution}

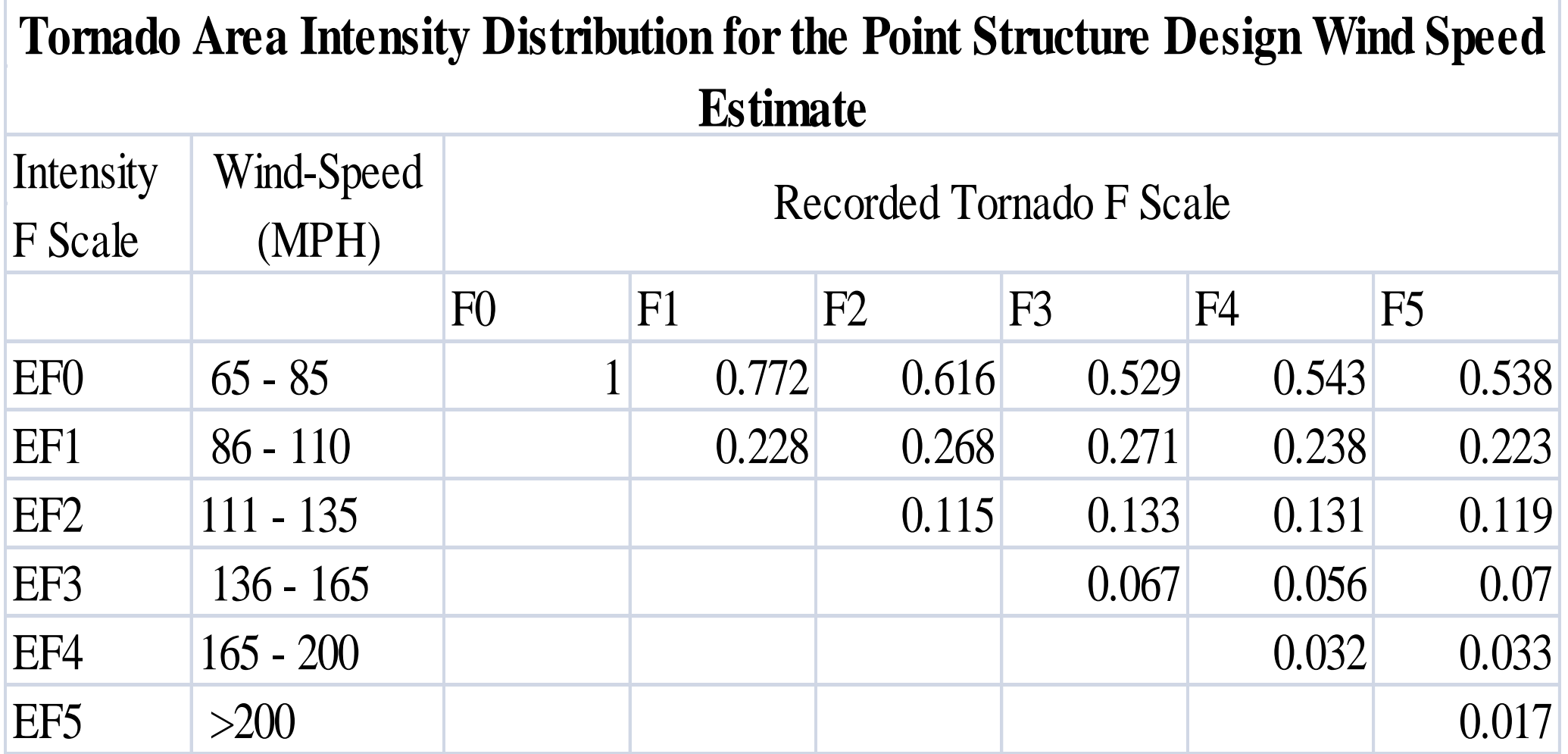

The interpretation of Table is as follows: 100 percent of the area impacted by F0 tornadoes has a wind speed in the 65 to $85 \mathrm{mph}$ range. For F1 tornadoes, 22.8 percent of the area has wind speeds in the 86 to $110 \mathrm{mph}$ range, and 77.2 percent of the area has wind speeds in the 65 to $85 \mathrm{mph}$ range. 


\section{Tornado Wind Speed Estimates for United States Nuclear Power Plant Sites}

(MPH)

\section{Table 6-1. NUREG/CR- 4461}

\begin{tabular}{|c|c|c|c|c|c|c|c|}
\hline \multirow[b]{2}{*}{ Index } & \multirow[b]{2}{*}{ Power Plant } & \multicolumn{3}{|c|}{ Fujita Scale } & \multicolumn{3}{|c|}{ Enhanced Fujita Scale } \\
\hline & & 1E-05 & $1 \mathrm{E}-06$ & $1 \mathrm{E}-07$ & $1 \mathrm{E}-05$ & $1 \mathrm{E}-06$ & 1E-07 \\
\hline 1 & Arkansas Nuclear & 198 & 250 & 297 & 160 & 195 & 227 \\
\hline 2 & Beaver Valley & 141 & 203 & 256 & 124 & 164 & 199 \\
\hline 3 & Big Rock Point & 108 & 175 & 229 & 103 & 146 & 183 \\
\hline 4 & Braidwood & 185 & 240 & 288 & 152 & 188 & 220 \\
\hline 5 & Browns Ferry & 206 & 257 & 303 & 166 & 200 & 232 \\
\hline 6 & Brunswick & 166 & 221 & 270 & 140 & 178 & 214 \\
\hline 7 & Byron & 185 & 240 & 288 & 152 & 188 & 220 \\
\hline 8 & Callaway & 171 & 228 & 278 & 143 & 180 & 213 \\
\hline 9 & Calvert Cliffs & 147 & 205 & 256 & 128 & 167 & 202 \\
\hline 10 & Catawba & 168 & 223 & 271 & 142 & 180 & 215 \\
\hline 11 & Clinton & 202 & 254 & 300 & 163 & 198 & 229 \\
\hline 12 & Columbia Generating Station & 59 & 143 & 210 & 78 & 127 & 167 \\
\hline 13 & Comanche Peak & 168 & 225 & 275 & 141 & 178 & 211 \\
\hline 14 & Cooper & 209 & 260 & 306 & 168 & 202 & 234 \\
\hline 15 & Crystal River & 167 & 227 & 278 & 141 & 179 & 212 \\
\hline 16 & D. C. Cook & 202 & 254 & 301 & 163 & 198 & 229 \\
\hline 17 & Davis-Besse & 185 & 240 & 288 & 152 & 188 & 220 \\
\hline 18 & Diablo Canyon & & 74 & 153 & & 86 & 134 \\
\hline 19 & Dresden & 185 & 240 & 288 & 152 & 188 & 220 \\
\hline 20 & Duane Arnold & 209 & 260 & 306 & 168 & 202 & 234 \\
\hline 21 & Edwin I. Hatch & 172 & 228 & 278 & 143 & 181 & 213 \\
\hline 22 & Fermi & 185 & 240 & 288 & 152 & 188 & 220 \\
\hline 23 & Fort Calhoun & 196 & 249 & 296 & 159 & 194 & 226 \\
\hline 24 & Ginna & 150 & 208 & 259 & 130 & 169 & 203 \\
\hline 25 & Grand Gulf & 194 & 247 & 295 & 158 & 193 & 225 \\
\hline 26 & H. B. Robinson & 158 & 214 & 264 & 135 & 173 & 208 \\
\hline 27 & Haddam Neck & 146 & 204 & 255 & 127 & 166 & 201 \\
\hline 28 & Hope Creek & 146 & 205 & 256 & 127 & 166 & 202 \\
\hline 29 & Indian Point & 146 & 204 & 255 & 127 & 166 & 201 \\
\hline 30 & James A. Fitzpatrick & 150 & 208 & 259 & 130 & 169 & 203 \\
\hline
\end{tabular}




\section{Tornado Wind Speed Estimates for United States Nuclear Power Plant Sites (MPH)}

\section{Table 6-1. NUREG/CR- 4461}

\begin{tabular}{|c|c|c|c|c|c|c|c|}
\hline \multirow[b]{2}{*}{ Index } & \multirow[b]{2}{*}{ Power Plant } & \multicolumn{3}{|c|}{ Fujita Scale } & \multicolumn{2}{|c|}{ Enhanced Fujita Scale } & \multirow[b]{2}{*}{ 1E-07 } \\
\hline & & $1 \mathrm{E}-05$ & 1E-06 & 1E-07 & 1E-05 & $1 \mathrm{E}-06$ & \\
\hline 31 & Joseph M. Farley & 179 & 234 & 283 & 148 & 184 & 217 \\
\hline 32 & Kewaunee & 177 & 232 & 280 & 146 & 183 & 216 \\
\hline 34 & LaCrosse & 186 & 240 & 289 & 153 & 189 & 221 \\
\hline 35 & Limerick & 146 & 205 & 256 & 127 & 166 & 202 \\
\hline 36 & Maine Yankee & 79 & 156 & 214 & 85 & 134 & 172 \\
\hline 37 & McGuire & 168 & 223 & 271 & 142 & 180 & 215 \\
\hline 39 & Monticello & 190 & 242 & 289 & 155 & 191 & 223 \\
\hline 40 & Nine Mile Point & 150 & 208 & 259 & 130 & 169 & 203 \\
\hline 41 & North Anna & 147 & 205 & 256 & 128 & 167 & 202 \\
\hline 42 & Oconee & 175 & 230 & 280 & 145 & 182 & 215 \\
\hline 43 & Oyster Creek & 146 & 205 & 256 & 127 & 166 & 202 \\
\hline 44 & Palisades & 202 & 254 & 301 & 163 & 198 & 229 \\
\hline 45 & Palo Verde & & 80 & 158 & & 89 & 136 \\
\hline 46 & Peach Bottom & 139 & 199 & 250 & 123 & 162 & 198 \\
\hline 48 & Pilgrim & 143 & 203 & 254 & 126 & 165 & 200 \\
\hline 49 & Point Beach & 177 & 232 & 280 & 146 & 183 & 216 \\
\hline 50 & Prairie Is land & 192 & 245 & 293 & 156 & 192 & 224 \\
\hline 51 & Quad-Cities & 209 & 260 & 306 & 168 & 202 & 234 \\
\hline 52 & Rancho Seco & & 93 & 168 & & 97 & 142 \\
\hline 53 & River Bend & 152 & 213 & 265 & 131 & 170 & 204 \\
\hline 54 & Salem & 146 & 205 & 256 & 127 & 166 & 202 \\
\hline 55 & San Onofre & & 113 & 185 & & 110 & 153 \\
\hline 56 & Seabrook & 143 & 203 & 254 & 126 & 165 & 200 \\
\hline 57 & Sequoyah & 186 & 239 & 287 & 154 & 188 & 221 \\
\hline 58 & Shearon Harris & 163 & 219 & 268 & 138 & 177 & 212 \\
\hline 59 & South Texas Project & 132 & 198 & 253 & 118 & 161 & 196 \\
\hline 60 & St. Lucie & 142 & 203 & 255 & 126 & 164 & 198 \\
\hline
\end{tabular}




\section{Tornado Wind Speed Estimates for United States Nuclear Power Plant Sites}

(MPH)

\section{Table 6-1. NUREG/CR- 4461}

\begin{tabular}{llllllll} 
& & \multicolumn{3}{c}{ Fujita Scale } & \multicolumn{3}{c}{ Enhanced Fujita Scale } \\
\cline { 3 - 8 } Index & Power Plant & 1E-05 & 1E-06 & 1E-07 & 1E-05 & 1E-06 & 1E-07 \\
\hline 61 & Summer & 158 & 214 & 264 & 135 & 173 & 208 \\
62 & Surry & 147 & 205 & 256 & 128 & 167 & 202 \\
63 & Susquehanna & 157 & 213 & 262 & 134 & 173 & 209 \\
64 & Three Mile island & 139 & 199 & 250 & 123 & 162 & 198 \\
65 & Trojan & & 84 & 161 & & 92 & 138 \\
66 & Turkey Point & 128 & 191 & 245 & 116 & 157 & 191 \\
67 & Vermont Ynakee & 146 & 204 & 255 & 127 & 166 & 201 \\
68 & Vogtle & 158 & 214 & 264 & 135 & 173 & 208 \\
69 & Waterford & 152 & 213 & 265 & 131 & 170 & 204 \\
70 & Watts bar & 186 & 239 & 287 & 152 & 188 & 221 \\
71 & Wolf Creek & 208 & 259 & 305 & 167 & 201 & 233 \\
72 & Yankee-Rowe & 146 & 204 & 255 & 127 & 166 & 201 \\
73 & Zion & 202 & 254 & 301 & 263 & 298 & 229
\end{tabular}




\section{High Wind PSA}

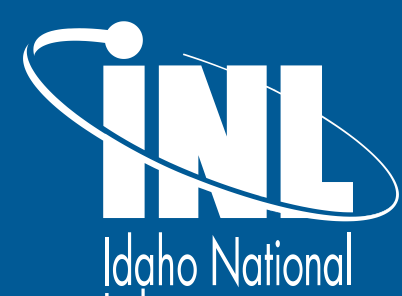

Laboratory 


\section{Overview of Methods and Results}

- Design for high winds does not meet the 1975 standard Review Plan; many key structures are steel buildings with light metal siding.

- The event (high wind) could not be screened out at the hazard frequency level.

- PSA performed in several "phases" starting with very conservative assumptions and providing refinement of value. 


\section{Overview of Methods and Results (continued)}

- Wind hazard and fragility analyses of IPPSS* were reviewed and updated. A new event tree based approach was used to define a set of unique wind induced plant states and their frequencies were evaluated.

- The core damage frequency resulting from each wind induced damage state was then quantified by modifying the internal event plant logic. 


\section{Wind Hazard Analysis}

- Detailed wind hazard analysis was performed. The methods and data used in the PSS have not changed over the years.

- Wind speed exceedance frequency curves for four principal directions (north, south, east and west) were provided for each of the high wind events (tornadoes, hurricanes and extratropical cyclones).

- Uncertainty in the wind hazard is represented by means of a family of five hazard curves (lower, mid-lower, median, mid-upper and upper confidence curves). 


\section{Combined Wind Speed Exceedance Frequencies - Plant West Direction}

\begin{tabular}{|c|c|c|c|c|c|}
\hline \multirow[b]{2}{*}{$\begin{array}{c}\mathrm{Vi}^{*} \\
\text { Fastest Mile } \\
\mathrm{mph}(\mathrm{m} / \mathrm{s})\end{array}$} & \multirow[b]{2}{*}{$\begin{array}{l}\text { Hazard } \\
\text { Curve }\end{array}$} & \multicolumn{4}{|c|}{ Windspeed Exceedance Frequencies Per Year } \\
\hline & & Hurricane & $\begin{array}{l}\text { Extratropical } \\
\text { Cyclone }\end{array}$ & Tornado & $\begin{array}{c}\text { Combined } \\
\text { Extratropical } \\
\text { Cyclone and } \\
\text { Tornado } \\
\end{array}$ \\
\hline $60(27)$ & $\begin{array}{l}\text { Lower } \\
\text { Median } \\
\text { Upper }\end{array}$ & $\begin{array}{l}5 \mathrm{E}-4 \\
6 \mathrm{E}-3 \\
3 \mathrm{E}-2\end{array}$ & $\begin{array}{l}4 \mathrm{E}-7 \\
2 \mathrm{E}-3 \\
4 \mathrm{E}-2\end{array}$ & $\begin{array}{l}- \\
- \\
-\end{array}$ & $\begin{array}{l}4.0 \mathrm{E}-7 \\
2.0 \mathrm{E}-3 \\
4.0 \mathrm{E}-2\end{array}$ \\
\hline $80(36)$ & $\begin{array}{l}\text { Lower } \\
\text { Median } \\
\text { Upper }\end{array}$ & $\begin{array}{l}2 \mathrm{E}-5 \\
3 \mathrm{E}-4 \\
1 \mathrm{E}-3\end{array}$ & $\begin{array}{c}- \\
4 \mathrm{E}-5 \\
4 \mathrm{E}-3\end{array}$ & $\begin{array}{l}8 \mathrm{E}-7 \\
9 \mathrm{E}-5 \\
5 \mathrm{E}-4\end{array}$ & $\begin{array}{l}8.0 \mathrm{E}-7 \\
1.3 \mathrm{E}-4 \\
4.5 \mathrm{E}-3\end{array}$ \\
\hline $100(45)$ & $\begin{array}{l}\text { Lower } \\
\text { Median } \\
\text { Upper }\end{array}$ & $\begin{array}{l}2 \mathrm{E}-7 \\
4 \mathrm{E}-6 \\
2 \mathrm{E}-5\end{array}$ & $\begin{array}{c}- \\
1 \mathrm{E}-6 \\
5 \mathrm{E}-4\end{array}$ & $\begin{array}{l}4 \mathrm{E}-7 \\
7 \mathrm{E}-6 \\
2 \mathrm{E}-4\end{array}$ & $\begin{array}{l}4.0 \mathrm{E}-7 \\
8.0 \mathrm{E}-6 \\
7.0 \mathrm{E}-4\end{array}$ \\
\hline $125(56)$ & $\begin{array}{l}\text { Lower } \\
\text { Median } \\
\text { Upper }\end{array}$ & $\begin{array}{c}- \\
- \\
1 \mathrm{E}-7\end{array}$ & $\begin{array}{c}- \\
- \\
2 \mathrm{E}-5\end{array}$ & $\begin{array}{l}1 \mathrm{E}-7 \\
3 \mathrm{E}-6 \\
7 \mathrm{E}-5\end{array}$ & $\begin{array}{l}1.0 \mathrm{E}-7 \\
3.0 \mathrm{E}-6 \\
9.0 \mathrm{E}-5\end{array}$ \\
\hline $150(67)$ & $\begin{array}{l}\text { Lower } \\
\text { Median } \\
\text { Upper }\end{array}$ & $\begin{array}{l}- \\
- \\
-\end{array}$ & $\begin{array}{c}- \\
- \\
2 \mathrm{E}-6\end{array}$ & $\begin{array}{l}5 \mathrm{E}-8 \\
2 \mathrm{E}-6 \\
3 \mathrm{E}-5\end{array}$ & $\begin{array}{l}5.0 \mathrm{E}-8 \\
2.0 \mathrm{E}-6 \\
3.2 \mathrm{E}-5\end{array}$ \\
\hline $200(90)$ & $\begin{array}{l}\text { Lower } \\
\text { Median } \\
\text { Upper }\end{array}$ & - & $\begin{array}{l}- \\
- \\
-\end{array}$ & $\begin{array}{c}- \\
3 \mathrm{E}-7 \\
2 \mathrm{E}-6\end{array}$ & $\begin{array}{c}- \\
3.0 \mathrm{E}-7 \\
2.0 \mathrm{E}-6\end{array}$ \\
\hline
\end{tabular}




\section{Wind Fragilities}

- Wind fragilities for key structures were calculated by reviewing building design drawings and wind design calculations, and the information obtained from the metal siding manufacturer.

- Various modes of failure of these structures were assessed for extreme wind loadings in each of the four principal wind directions.

- Analysis considered building shape factors, roofing and siding failures from impinging winds and negative pressures, and building frame and anchor failures.

- Funneling and shielding effects of these buildings were also considered. 


\section{Wind Speed Fragility Curves}

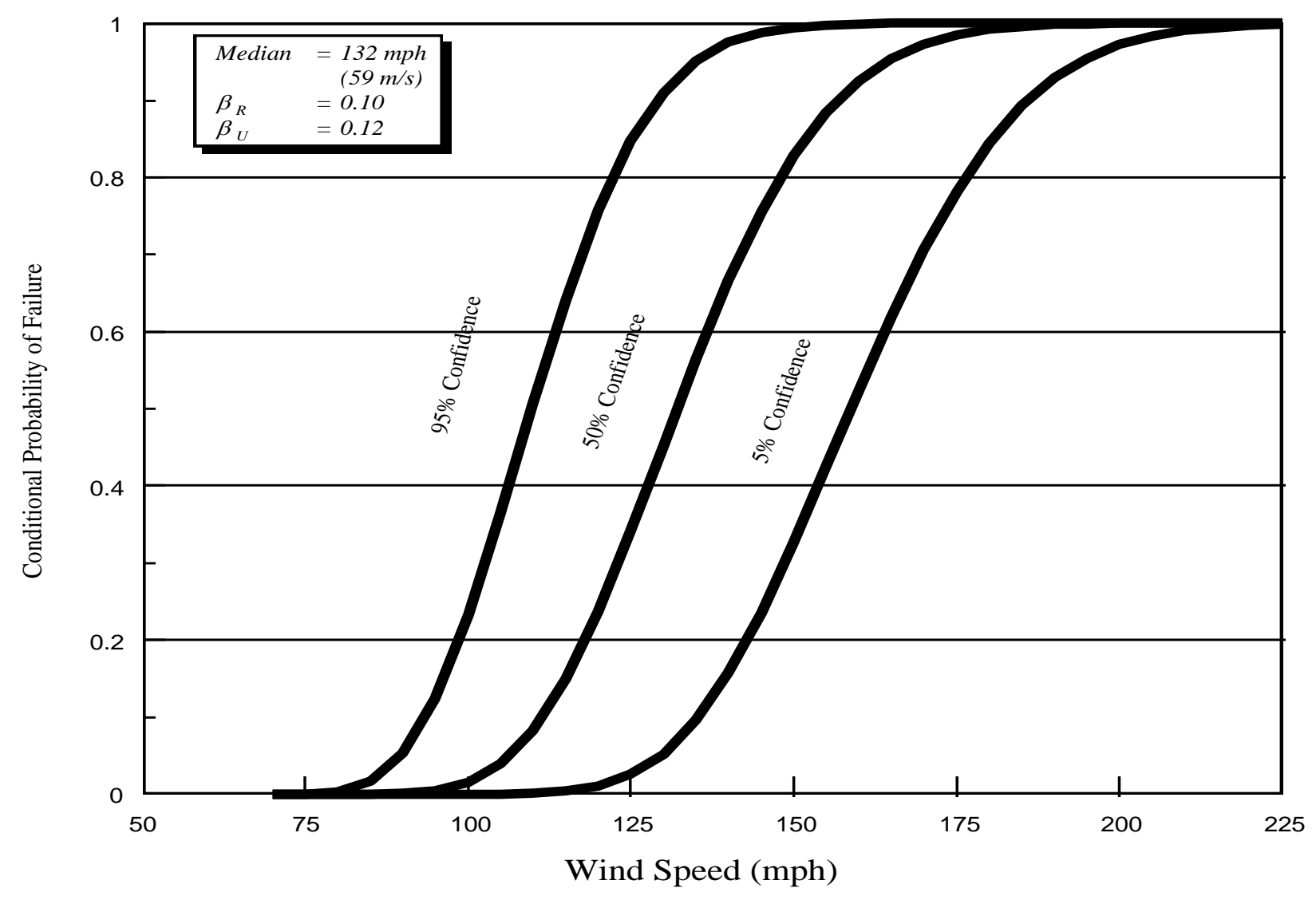




\section{Wind Fragilities of Key Structures For West Direction}

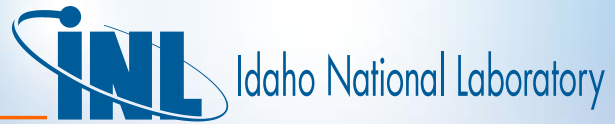

\begin{tabular}{||l|c|c|c||}
\hline \multicolumn{1}{|c|}{ Structure } & $\begin{array}{c}\text { Median Capacity } \\
\text { mph }(\mathrm{m} / \mathrm{s})\end{array}$ & $\beta_{\mathrm{R}}$ & $\beta_{\mathrm{U}}$ \\
\hline \hline S1 - Gas Turbine 1 Shelter & $83(37)$ & 0.15 & 0.20 \\
S3 - Aux. Feed Pump Bldg. & $222(99)$ & 0.10 & 0.16 \\
S4 - Control Bldg. & $167(75)$ & 0.10 & 0.10 \\
S5 - PAB (metal portion) & $174(78)$ & 0.10 & 0.05 \\
S6 - Diesel Gen. Bldg. & $132(59)$ & 0.10 & 0.12 \\
S7 - Stack & $360(161)$ & 0.10 & 0.12 \\
S12 - Unit 1 Turbine Bldg. & $200(89)$ & 0.07 & 0.07 \\
S13 - Unit 2 Turbine Bldg & $170(75))$ & 0.10 & 0.07 \\
S14 - Gas Turbine 3 Shelter & $83(37)$ & 0.15 & 0.20 \\
\hline \hline
\end{tabular}




\section{Wind Damage Event Tree}

- Wind induced failures were evaluated separately from random equipment failures using an event tree logic approach with the objective of identifying and quantifying a unique set of wind damage states.

- Components not susceptible to wind damage, but only susceptible to tornado missile damage (e.g. RWST) were excluded; tornado missile damage probability was separately estimated. 


\section{Wind Damage Event Tree (continued)}

- Consequential effect of a structural failure on loss of function of equipment located in another structure was considered:

- One building collapsing on to another

- Loss of supporting equipment in the damaged structure rendering the loss of equipment function in another 


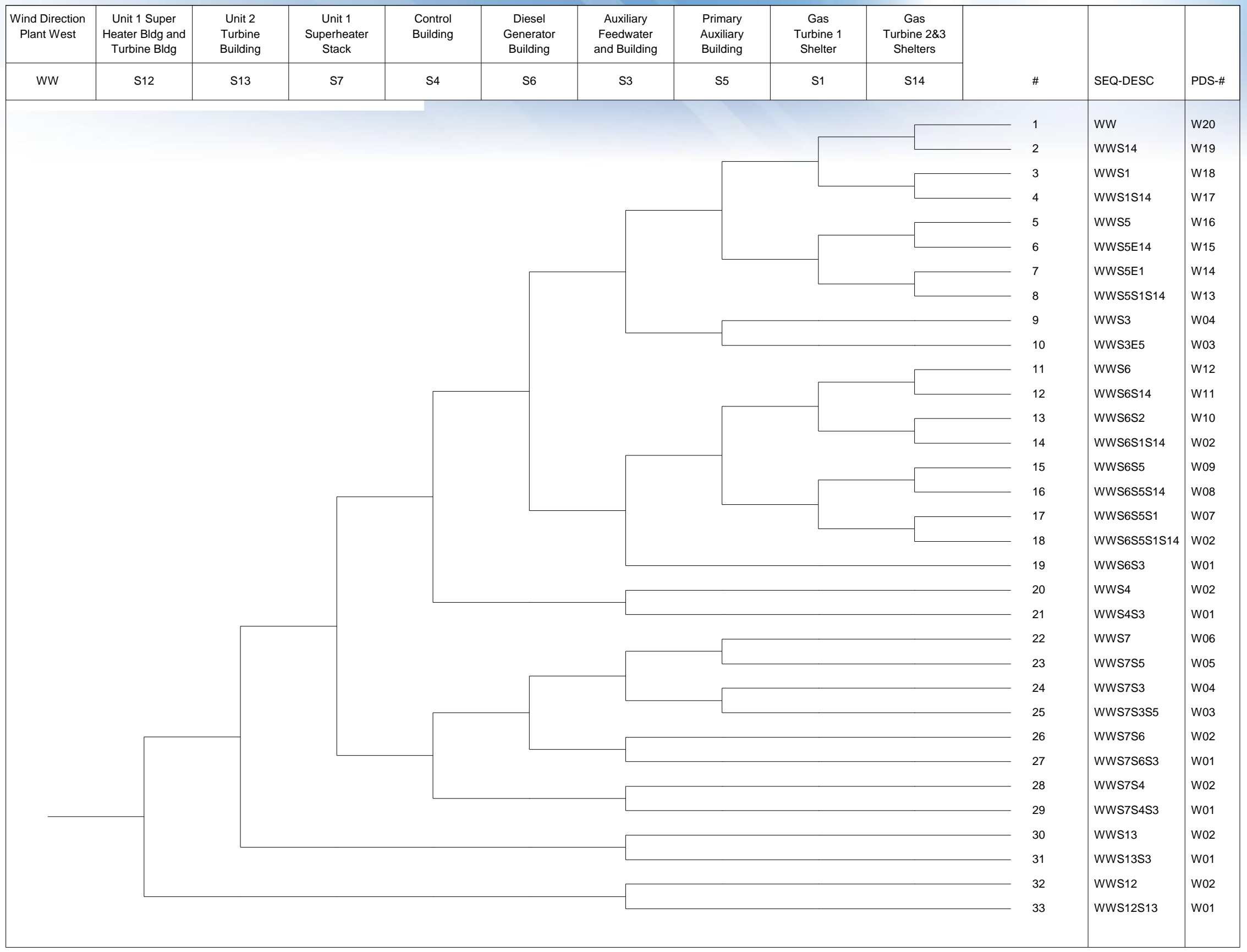




\section{Wind Plant Damage States}

\begin{tabular}{|l|l|}
\hline PDS & Description \\
\hline W01 & EDG power and control failed, GTs failed, AFW failed \\
\hline W02 & EDG power and control failed, GTs failed, AFW success \\
\hline W03 & AFW failed, PAB failed, GTs failed, EDG pwr \& ctl success \\
\hline W04 & AFW failed, GTs failed, EDG power and control success \\
\hline W05 & PAB failed, GTs failed, EDG pwr \& ctl success, AFW success \\
\hline W06 & GTs failed, PAB success, EDG pwr \& ctl success, AFW success \\
\hline W07 & GT1 failed, PAB failed, EDG pwr failed, GT2\&3 and AFW success \\
\hline Etc. & \\
\hline
\end{tabular}

W01 and W02 lead directly to $C D$, others need additional failures 
Mean Annual Frequencies of Wind Damage State from Phase 1 Quantification (Tornado and Extratropical Storms)

\begin{tabular}{|c|c|c|c|c||}
\hline \multirow{2}{*}{$\begin{array}{c}\text { Plant } \\
\text { Damage } \\
\text { States }\end{array}$} & \multicolumn{4}{|c||}{ WIND DIRECTION } \\
\cline { 2 - 5 } & North & East & South & West \\
\hline \hline w01 & $9.51 \mathrm{E}-7$ & $5.74 \mathrm{E}-7$ & $5.27 \mathrm{E}-7$ & $8.60 \mathrm{E}-7$ \\
\hline w02 & $1.08 \mathrm{E}-5$ & $1.16 \mathrm{E}-5$ & $8.37 \mathrm{E}-6$ & $3.21 \mathrm{E}-5$ \\
\hline w10 & $1.27 \mathrm{E}-6$ & $1.09 \mathrm{E}-6$ & $7.69 \mathrm{E}-7$ & $1.25 \mathrm{E}-6$ \\
\hline w11 & $1.27 \mathrm{E}-6$ & $1.09 \mathrm{E}-6$ & $7.69 \mathrm{E}-7$ & $1.25 \mathrm{E}-6$ \\
\hline w12 & $7.30 \mathrm{E}-7$ & $3.73 \mathrm{E}-7$ & $3.30 \mathrm{E}-7$ & $4.33 \mathrm{E}-7$ \\
\hline w17 & $8.15 \mathrm{E}-5$ & $3.75 \mathrm{E}-5$ & $3.34 \mathrm{E}-5$ & $3.66 \mathrm{E}-4$ \\
\hline w18 & $1.68 \mathrm{E}-4$ & $6.14 \mathrm{E}-5$ & $7.69 \mathrm{E}-7$ & $4.32 \mathrm{E}-4$ \\
\hline $\mathrm{w19}$ & $1.68 \mathrm{E}-4$ & $6.14 \mathrm{E}-5$ & $5.29 \mathrm{E}-5$ & $4.32 \mathrm{E}-4$ \\
\hline $\mathrm{w} 20$ & $5.63 \mathrm{E}-4$ & $1.81 \mathrm{E}-4$ & $1.60 \mathrm{E}-4$ & $7.58 \mathrm{E}-4$ \\
\hline \hline
\end{tabular}


Mean Annual Frequencies of Wind Damage State from Phase 1 Quantification (Hurricanes )

\begin{tabular}{|c|c|c|c|c||}
\hline \multirow{2}{*}{$\begin{array}{c}\text { Plant Damage } \\
\text { States }\end{array}$} & \multicolumn{4}{|c||}{ WIND DIRECTION } \\
\cline { 2 - 5 } w01 & North & East & South & West \\
\hline \hline w02 & $1.49 \mathrm{E}-6$ & $1.96 \mathrm{E}-9$ & $9.43 \mathrm{E}-9$ & $2.23 \mathrm{E}-6$ \\
\hline w10 & $1.02 \mathrm{E}-6$ & $7.43 \mathrm{E}-10$ & $8.94 \mathrm{E}-9$ & $3.10 \mathrm{E}-7$ \\
\hline w11 & $1.02 \mathrm{E}-6$ & $7.43 \mathrm{E}-10$ & $8.93 \mathrm{E}-9$ & $3.10 \mathrm{E}-7$ \\
\hline w12 & $1.13 \mathrm{E}-6$ & $5.99 \mathrm{E}-10$ & $1.37 \mathrm{E}-8$ & $1.97 \mathrm{E}-7$ \\
\hline w17 & $2.28 \mathrm{E}-4$ & $3.43 \mathrm{E}-7$ & $4.52 \mathrm{E}-6$ & $2.77 \mathrm{E}-4$ \\
\hline w18 & $6.57 \mathrm{E}-4$ & $1.10 \mathrm{E}-6$ & $8.94 \mathrm{E}-9$ & $4.25 \mathrm{E}-4$ \\
\hline w19 & $6.57 \mathrm{E}-4$ & $1.10 \mathrm{E}-6$ & $1.70 \mathrm{E}-5$ & $4.25 \mathrm{E}-4$ \\
\hline w20 & $2.55 \mathrm{E}-3$ & $4.52 \mathrm{E}-6$ & $7.94 \mathrm{E}-5$ & $8.22 \mathrm{E}-4$ \\
\hline \hline
\end{tabular}




\section{Refinement of Fragilities and Sequence Modeling}

- Sensitivity studies on Phase 1 results showed that the failures of turbine building and the diesel generator building dominate the contribution to core damage frequency.

- The wind capacity of the turbine building was refined by accounting for the likelihood that part of the siding will blow away at lower wind speeds thereby reducing the wind loading on the structure. When this was done, it was found that the contribution of the turbine building failure to the core damage frequency was substantially reduced. 


\section{TII Idaho National laboratory}

\section{Refinement of Fragilities and Sequence Modeling}

(continued)

- Diesel generator building roof failure was judged to lead to total failure of $D G$ in $70 \%$ of the time.

- Consider the distances between the EDG building and Gas Turbines 2 and 3 , the probability of a tornado simultaneously striking and damaging the EDG building and the three gas turbines was estimated to be 0.14 (not 1.0 as assumed in Phase 1 quantification). 


\section{Wind Induced CD Calculated}

- Wind damage states propagated through internal events event trees

- Internal events event trees modified to account for dependencies associated with each wind damage state, e.g.:

- Offsite power assumed to always be lost

- EDG assumed failed for w01, w02, w10, w11, and w12

- EDG mission times increased from 6 hours to 24 hours 


\section{Final
States}

\begin{tabular}{|c|c|}
\hline \multicolumn{2}{|c|}{ CORE DAMAGE FREQUENCY FROM WIND DAMAGE STATES } \\
\hline Wind Damage State & Mean Core Damage Frequency / yr \\
\hline $\begin{array}{l}\text { Tornadoes } \\
\text { IE Name: w01TT } \\
\text { IE Name: w02TT } \\
\text { IE Name: w10TT } \\
\text { IE Name: w11TT } \\
\text { IE Name: w12TT } \\
\text { IE Name: w17TT } \\
\text { IE Name: w18TT } \\
\text { IE Name: w19TT } \\
\text { IE Name: w20TT }\end{array}$ & $\begin{array}{c}\text { Total: } 2.4900 \mathrm{E}-06 \\
\text { Total: } 1.0599 \mathrm{E}-05 \\
\text { Total: } 7.4718 \mathrm{E}-07 \\
\text { Total: } 8.6480 \mathrm{E}-08 \\
\text { Total: } 1.6725 \mathrm{E}-07 \\
\text { Total: } 2.9930 \mathrm{E}-07 \\
\text { Total: } 1.0864 \mathrm{E}-06 \\
\text { Total: } 7.7233 \mathrm{E}-07 \\
\text { Total: } 5.8171 \mathrm{E}-07 \\
\text { Total from Tornadoes } 1.683 \mathrm{E}-5\end{array}$ \\
\hline $\begin{array}{l}\text { Hurricanes } \\
\text { IE Name: w01HT } \\
\text { IE Name: w02HT } \\
\text { IE Name: w10HT } \\
\text { IE Name: w11HT } \\
\text { IE Name: w12HT } \\
\text { IE Name: w17HT } \\
\text { IE Name: w18HT } \\
\text { IE Name: w19HT } \\
\text { IE Name: w20HT }\end{array}$ & $\begin{aligned} & \text { Total: } 3.3498 \mathrm{E}-08 \\
& \text { Total: } 1.7810 \mathrm{E}-07 \\
& \text { Total: } 2.0632 \mathrm{E}-08 \\
& \text { Total: } 3.6022 \mathrm{E}-08 \\
& \text { Total: } \mathbf{1 . 1 0 5 0 \mathrm { E } - 0 8} \\
& \text { total: } 4.7359 \mathrm{E}-07 \\
& \text { Total: } 3.3732 \mathrm{E}-07 \\
& \text { Total: } 4.6580 \mathrm{E}-07 \\
& \text { Total: } 8.7974 \mathrm{E}-07 \\
& \text { Total from Hurricanes } 2.4 \mathrm{E}-06\end{aligned}$ \\
\hline $\begin{array}{l}\text { Extratropical Cyclone } \\
\text { IE Name: w01CT } \\
\text { IE Name: w02CT } \\
\text { IE Name: w10CT } \\
\text { IE Name: w11CT } \\
\text { IE Name: w12CT } \\
\text { IE Name: w17CT } \\
\text { IE Name: w18CT } \\
\text { IE Name: w19CT } \\
\text { IE Name: w20CT }\end{array}$ & $\begin{array}{r}\text { Total: } \mathbf{1 . 0 8 0 0 E - 0 8} \\
\text { Total: } 7.5592 \mathrm{E}-06 \\
\text { Total: } 4.3293 \mathrm{E}-07 \\
\text { Total: } \mathbf{7 . 0 0 9 3 \mathrm { E } - 0 7} \\
\text { Total: } \mathbf{1 . 4 4 3 7 \mathrm { E } - 0 7} \\
\text { Total: } \mathbf{9 . 3 8 4 8 \mathrm { E } - 0 7} \\
\text { Total: } \mathbf{3 . 7 6 3 8 \mathrm { E } - 0 7} \\
\text { Total: } 2.696 \mathrm{E}-07 \\
\text { total: } \mathbf{6 . 8 0 2 1 \mathrm { E } - 0 7} \\
\text { Total from Extratropical Cyclones } 1.1 \mathrm{E}-05\end{array}$ \\
\hline Total Contribution to CDF From High Winds & 3.03E-05 \\
\hline
\end{tabular}




\section{Summary of Major Contributors}

- Tornadoes and extratropical cyclones are the major contributors to total core damage frequency (28\%).

- The dominant accident scenarios occur due to wind damage state WO2, which represents loss of normal and emergency power with auxiliary feed available.

- Dominant structural failures are: the Emergency Diesel Generator Building and the Gas Turbine shelters, with lower contributions from the Turbine Building and Control Building.

- There exists no single (or a small set of) structure or component especially vulnerable to high winds. No upgrade of the plant structures was identified which would cost effectively reduce the wind induced risk contribution. 


\section{External Floods}




\section{External Floods}

- NRC Regulatory Requirements:

- 10 CFR Part 50 Appendix A Criterion 2, 10 CFR Part 100, 10 CFR Part 100 Appendix A

- Other Related Documents

- Regulatory Guide 1.27, 1.59, 1.102

- SRP No. 2.4.2, 2.4.3, 2.4.4, 3.4.1

- References:

- Design-Basis Flood Estimation for Site Characterization at Nuclear Power Plants in the United States of America, NUREG/CR- 7046, PNL-20091

- Uncertainty Analysis for Large Dam Failure Frequencies Based on Historical Data - Ferrante, F.; PSAM11 Conference.

- USACE (2011) National Inventory of Dams. US Army Corps of Engineers, http://nid.usace.army.mil. 


\section{Flooding Phenomena}

- Flooding due to intense local precipitation and runoff effects.

- Stream or river flooding.

- Dam failures.

- Coastal and estuarine flooding.

- Tsunami flooding.

- High water level, wave effects, surges, seiche. 


\section{Flooding Terminology}

- PFHA Probabilistic Flood Hazard Assessment

- PMF - Probable Maximum Flood

- PMP - Probable Maximum Precipitation

- PMSS - Probable Maximum Storm Surge

- PMH - Probable Maximum Hurricane

- PMWS - Probable Maximum Windstorm

- PMS - Probable Maximum Seiche

- PMT - Probable Maximum Tsunami 


\section{Flooding Reviewed in FSAR or SER}

- Example of nonconformance to SRP criteria: estimation of the probable maximum precipitation (PMP) at the site was based on earlier or other information sources; e.g., - Hydrometerological Report (HMR)33 (1956).

- New PMP criteria developed by the National Weather Service, presented in Generic Letter No. 89-22.

- Reanalysis of potential flooding impacts based on more recent HMRs; e.g., HMR-51 and HMR-52. 


\section{Example from the IPEEE}

- Some of the calculations of the PMF due to runoffs were based on the PMP data from HMR-33.

- Maximum flood water level below door sills of safety-related buildings.

- Using data from HMR-51 and HMR-52, flood water would rise above the door sills of three safety-related buildings.

- Internal flood depths calculated were shown to be below the location of safety-related equipment in the buildings. 


\section{Major Elements of External Flooding PRA}

- Flooding hazard analysis

- Evaluation of flooding pathways, water level, and damage to SSCs

- Plant and system response analysis including quantification 


\section{External Flooding Event}

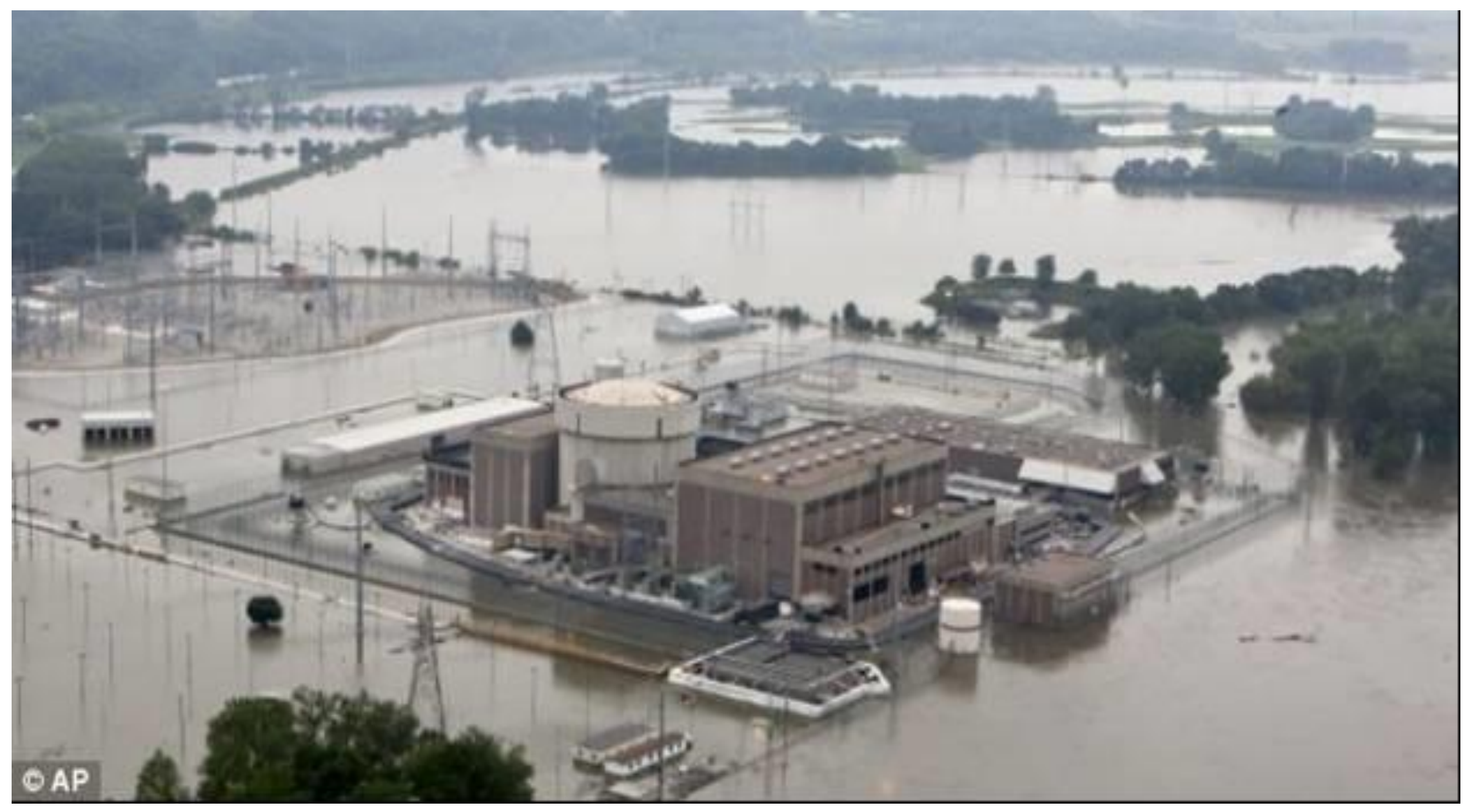




\section{External Flooding Event}

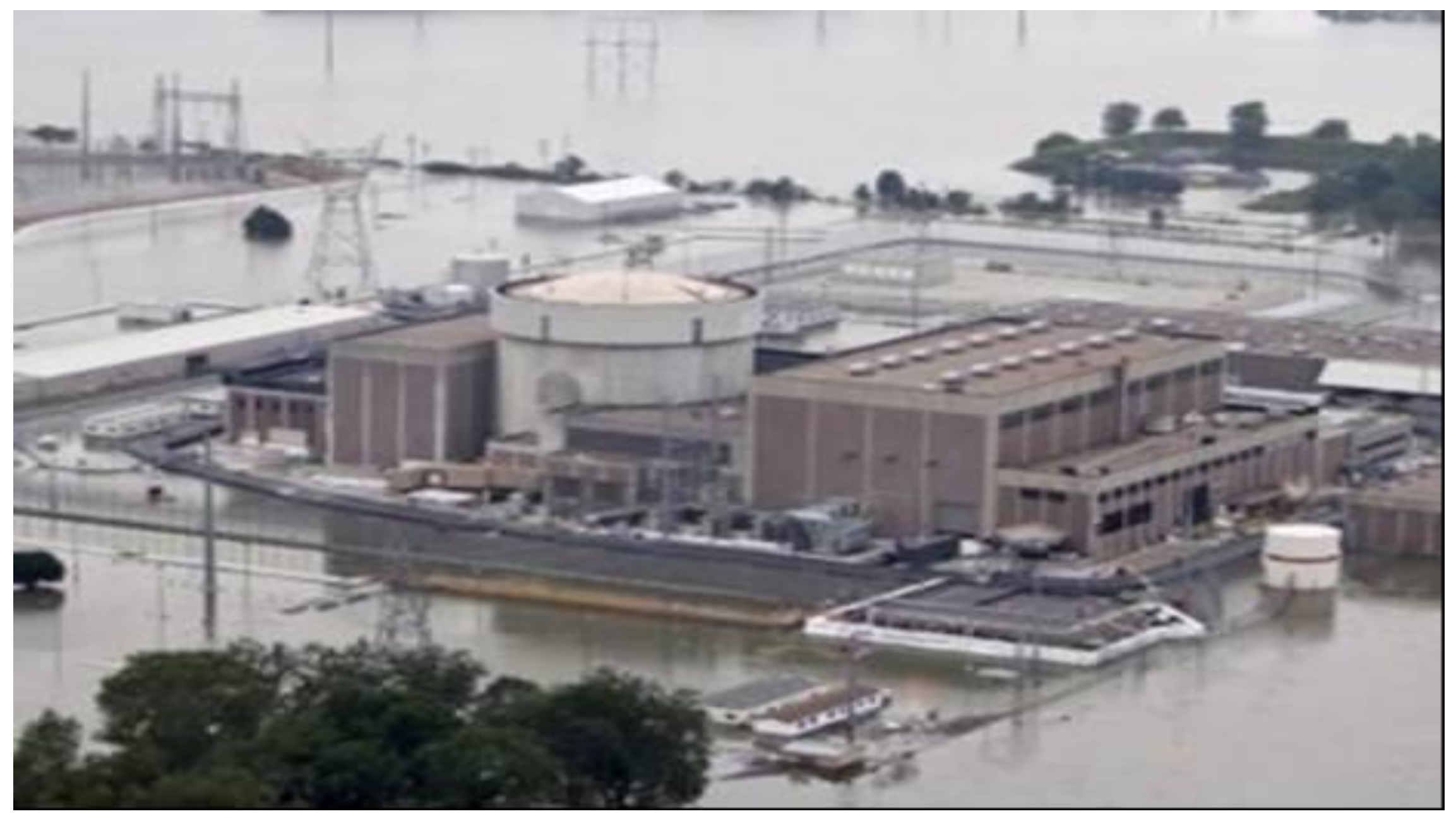




\section{External Flooding Event}

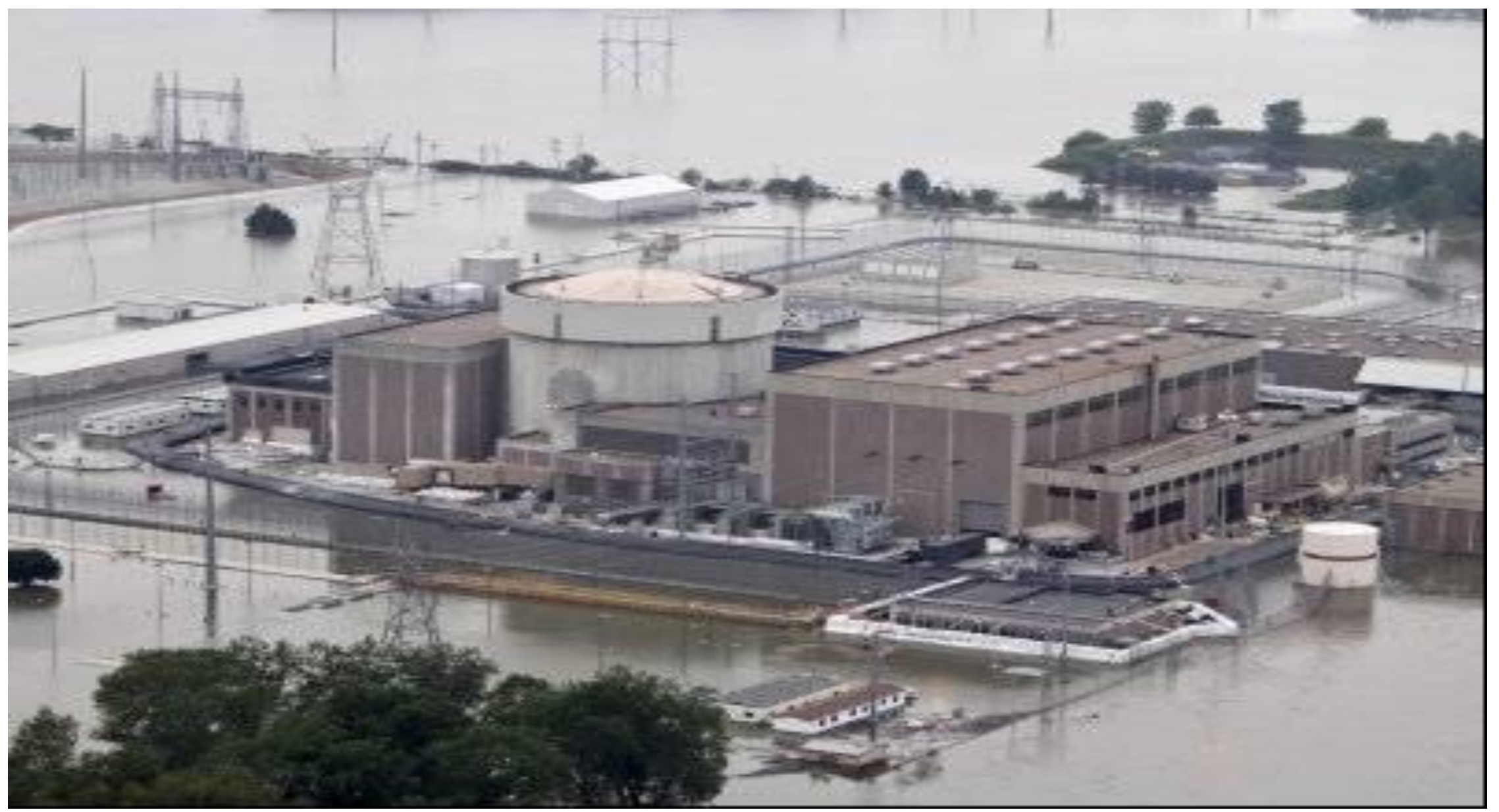




\section{External Flooding Event}

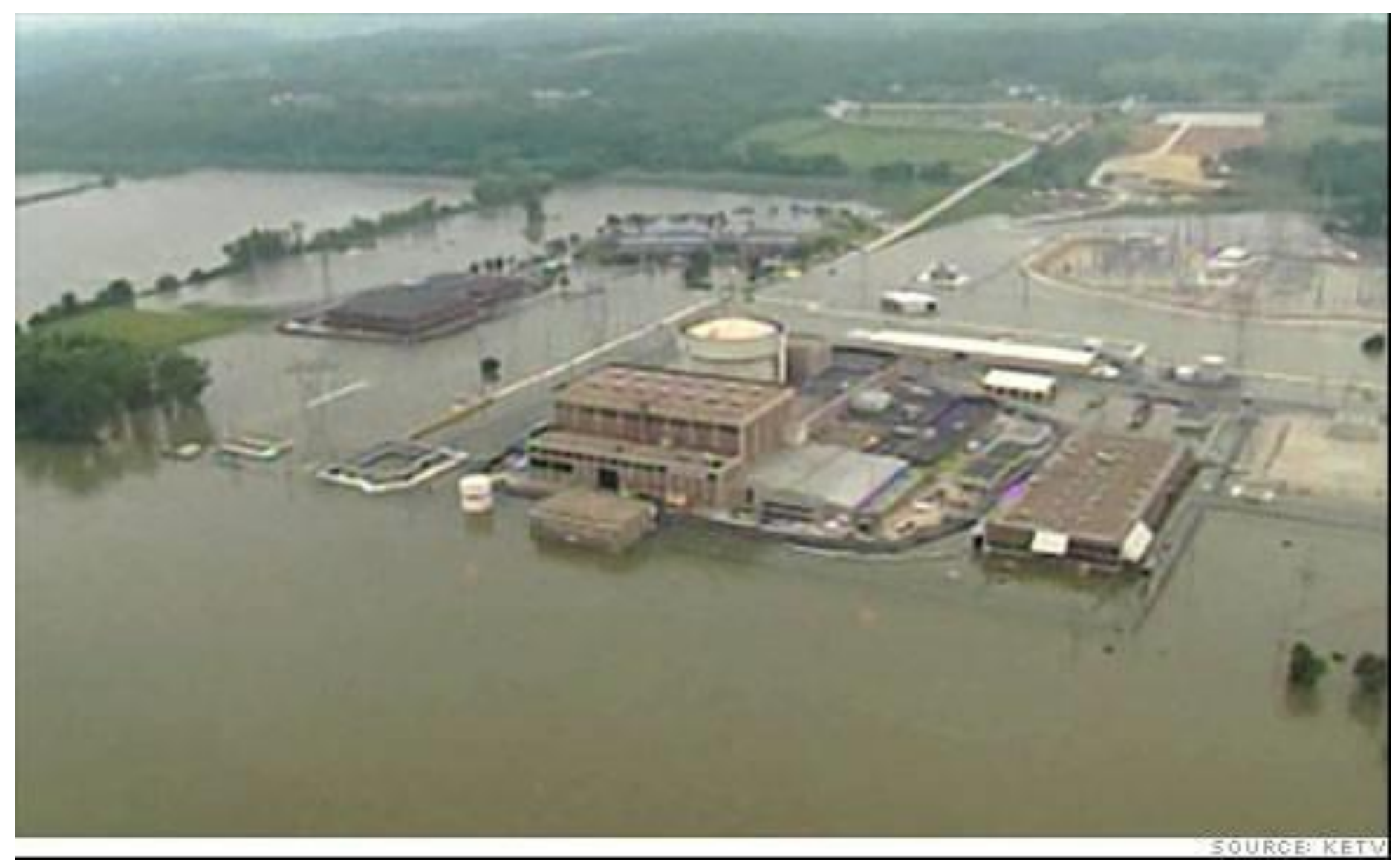




\section{External Flooding Event}

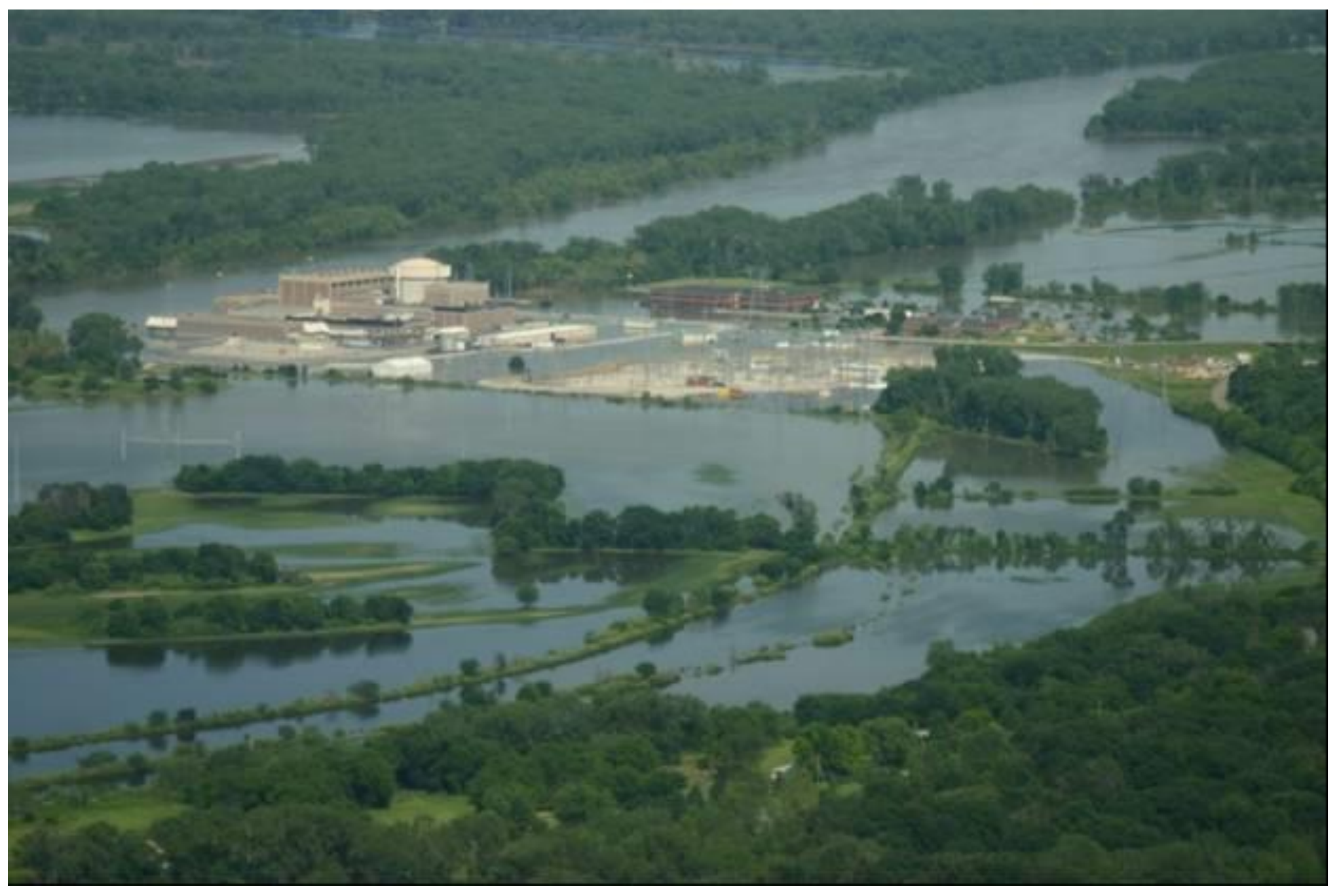




\section{External Flooding Event}

- Mindset:

"During identification and evaluation of flood barriers, unsealed through wall penetrations in the outside wall of the intake, auxiliary and chemistry and radiation protection buildings were identified that are below the licensing basis flood elevation. A summary of the root causes included: a weak procedure revision process; insufficient oversight of work activities associated with external flood matters; ineffective identification, evaluation and resolution of performance deficiencies related to external flooding; and 'safe as is' mindsets relative to external flooding events. 


\section{Transportation Accidents}




\section{Transportation Accidents}

- NRC Regulatory Requirements:

- 10 CFR Part 50.34, 10 CFR Part 100, 10 CFR Part 100.10

- Other Related Documents

- Regulatory Guide 1.78, 1.91, 1.95

- SRP No. 2.2.1, 2.2.2, 2.2.3, 3.5.1.5, 3.5.1.6

- NRC regulatory guides are deterministic in nature; for example:

- Shipment of hazardous material of certain weight, below certain frequency.

- Peak positive incident overpressure below 1 psi from an explosion on transportation route.

- Plant is at least 2 statute miles beyond the nearest edge of a federal airway, holding pattern, or approach pattern. 


\section{Transportation Accidents (continued)}

- Modes of Transportation

- Air Traffic (commercial, general, military)

- Ground Traffic (on roads and railways)

- Water Traffic (ship and barge)

- Pipeline (gas and oil)

- Transportation accidents were evaluated at the time of OL issuance and are documented in the FSAR and SER.

- Plants designed against NRC's current criteria should have no significant vulnerability to severe accidents from transportation accident events.

- Updated analysis may be required due to changes since the original design.

- Older plants may not meet NRC's current criteria. 


\section{Example for Aircraft hazards}




\section{Aircraft Hazards}

- If acceptance criteria for siting with respect to aircraft hazards are no longer true, then detailed review of aircraft hazards must be performed.

- Procedure for estimating the frequency of aircraft crashing into the plant $P_{F A}$ is provided in the SRP No. 3.5.1.6:

- For airways: $\mathrm{P}_{\mathrm{FA}}=\mathrm{C} \bullet \mathrm{N} \bullet \mathrm{A} / \mathrm{w}$

$-\mathrm{C}=$ in-flight crash rate per mile for aircraft using airway.

$-\mathrm{N}=$ number of flights per year along airway.

$-\mathrm{A}=$ effective area of plant in square miles.

- $\mathbf{w}=$ width of airway in miles (plus twice the distance from the airway edge to the site when site is outside the airway) or ( $1 / w$ is defined as Lateral Crash Density). 


\section{Aircraft Hazards (continued)}

- Source of aviation accident data is the NTSB, and source of information on airport activity and flights is the FAA.

- Aircraft hazard analysis must be updated using current data: number of operations/flights and aircraft crash rates. 


\section{Aircraft Impact Evaluation (1978)}

\begin{tabular}{|c|c|c|c|c|c|c|c|}
\hline Atitus & 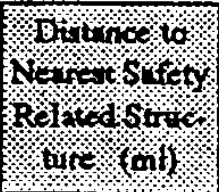 & 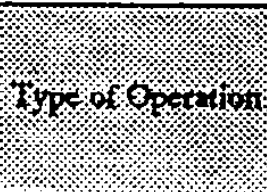 & montom & \%mol & ontorts & Oprof & Woroth \\
\hline \multirow[t]{3}{*}{$V-16$} & \multirow[t]{3}{*}{4.5} & Air Carrier & 27,740 & $5.9 \times 10^{-10}$ & 0.05 & $6 \times 10^{-4}$ & $5 \times 10^{-10}$ \\
\hline & & Military & 5.110 & $1.2 \times 10^{-8}$ & 0.04 & $5.6 \times 10^{-3}$ & $1.4 \times 10^{-8}$ \\
\hline & & Gencral Aviation & 107,300 & $9.8 \times 10^{-3}$ & 0.01 & $1.2 \times 10^{-4}$ & $1.3 \times 10^{-2}$ \\
\hline$V-461$ & 3.2 & General Aviation & 100 & $9.8 \times 10^{-8}$ & 0.01 & $1.7 \times 10^{-3}$ & $2 \times 10^{-10}$ \\
\hline$J-65$ & 4.5 & Air Carrier & 37,230 & $5.9 \times 10^{.10}$ & 0.05 & $6.0 \times 10^{-4}$ & $7 \times 10^{-10}$ \\
\hline$J-4$ & 2.9 & Air Cerrier & 37.230 & $5.9 \times 10^{-10}$ & 0.05 & $7.7 \times 10^{-3}$ & $8.5 \times 10^{-9}$ \\
\hline LAFB & 125 & Military & 54,800 & $1.2 \times 10^{-3}$ & 0.04 & $1.9 \times 10^{-6}$ & $<1 \times 10^{-10}$ \\
\hline $\operatorname{RR} 218$ & 12.6 & Military & 180 & $12 \times 10^{-3}$ & 0.04 & $1.7 \times 10^{-6}$ & $<1 \times 10^{-10}$ \\
\hline $\operatorname{IR272}$ & 12.4 & Military & 500 & $1.2 \times 10^{-6}$ & 0.04 & $2.1 \times 10^{-6}$ & $<1 \times 10^{-10}$ \\
\hline PVNOS(a) & 0.13 & Helicopter & 1,000 & $4.9 \times 10^{-7}(a)$ & מ. & $7.5 \times 10^{-5}(a)$ & $3.7 \times 10^{-4}$ \\
\hline TOTAL & & & & & & & $7.4 \times 10^{-8}$ \\
\hline
\end{tabular}

Notes to Table 5.3-2: (a) PVNGS data refers to helicopter traffic at the PVNGS helipad. For this airway only the crash rate is given in crashes per takeoff or landing operation (rather than per mile), and the value listed in the lateral crash density column represents the conditional probability of striking a safety related structure. 


\section{Aircraft Impact Evaluation (1993)}

\begin{tabular}{|c|c|c|c|c|c|c|c|}
\hline $\mathrm{A}-1+\mathrm{y}$ & 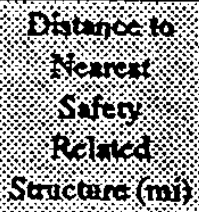 & $1014 \times 1010$ & $6 \mathrm{fum}_{\mathrm{m}}$ & $\left.w_{1+10}\right)$ & Iffoctuc & 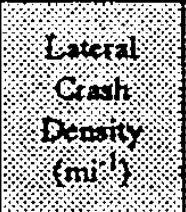 & probugility \\
\hline \multirow[t]{3}{*}{$V-16$} & \multirow[t]{3}{*}{4.5} & Air Carrier & 33,116 & $1.18 \times 10^{-9}$ & 0.05 & $6 \times 10^{-4}$ & $12 \times 10^{-9}$ \\
\hline & & Military & 0 & $2.36 \times 10^{-3}$ & 0.04 & $5.6 \times 10^{-3}$ & 0 \\
\hline & & General Aviation & 18,148 & $1.41 \times 10^{-7}$ & 0.01 & $1.2 \times 10^{4}$ & $3.1 \times 10^{-9}$ \\
\hline$V-46 I$ & 3.2 & General Aviation & 100 & $1.41 \times 10^{-7}$ & 0.01 & $1.7 \times 10^{-3}$ & $2.4 \times 10^{-10}$ \\
\hline$J .65$ & 4.5 & Air Carrier & 44,480 & $1.18 \times 10^{-9}$ & 0.05 & $6.0 \times 10^{-4}$ & $1.6 \times 10^{-9}$ \\
\hline$J-4$ & 2.9 & Air Carrier & 44,480 & $1.18 \times 10^{-9}$ & 0.05 & $7.7 \times 10^{-3}$ & $2.0 \times 10^{-8}$ \\
\hline LAFB & 12.5 & Military & 42,800 & $2.36 \times 10^{-8}$ & 0.04 & $1.9 \times 10^{-6}$ & $8 \times 10^{-11}$ \\
\hline RR218 & 12.6 & Military & 180 & $2.36 \times 10^{-8}$ & 0.04 & $1.7 \times 10^{-6}$ & $<1 \times 10^{-10}$ \\
\hline R272 & 12.4 & Military & 0 & $2.36 \times 10^{-2}$ & 0.04 & $2.1 \times 10^{-6}$ & 0 \\
\hline PVNaS $(\cdot)$ & 0.13 & Helicopter & 100 & $4.9 \times 10^{-7}(a)$ & - & $7.5 \times 10^{-5}(a)$ & $3.7 \times 10^{-9}$ \\
\hline OTAL & & & & & & & $3.0 \times 10^{-8}$ \\
\hline
\end{tabular}

Notes to Table 5.3-3: (a) PVNGS data refers to helicopter traffic at the PVNGS helipad. For this airway only the crash rate is given in crashes per takeoff or landing operation (rather than per mile), and the value listed in the lateral crash density column represents the conditional probability of striking a safety related structure. 


\section{Aircraft Hazards (continued)}

- Number of Allowed Operations per 10CFR100.20

Airport within $5-10$ miles of site

- Number of Allowed Operation $=500 * D^{\wedge} 2$

- Number of Allowed Operations

Airport Beyond 10 miles of site

- Number of Allowed Operation $=1000{ }^{*} \mathrm{D}^{\wedge} 2$

Where

$\mathrm{D}=$ distance airport located from the site 


\section{Annual Operations at Airports Near Site}

\begin{tabular}{|c|c|c|c|c|}
\hline Airport & $\begin{array}{c}\text { Closest Distance } \\
\text { and Orientation } \\
\text { between the } \\
\text { Airport and } \\
\text { PVNGS (mi) }\end{array}$ & $\begin{array}{c}1978 \\
\text { Estimated } \\
\text { No. of } \\
\text { Annual } \\
\text { Operations }\end{array}$ & $\begin{array}{c}1993 \\
\text { Estimated } \\
\text { No. of } \\
\text { Annual } \\
\text { Operations }\end{array}$ & $\begin{array}{c}\text { Regulatory } \\
\text { Guide } 1.70 \\
\text { Allowable } \\
\text { Number of } \\
\text { Operations }\end{array}$ \\
\hline $\begin{array}{c}\text { Buckeye Municipal } \\
\text { Airport }\end{array}$ & 10.8 & 6,000 & 100,000 & 116,000 \\
\hline Pierce Airport & $15.5 \mathrm{E}$ & 23,586 & 23,586 & 240,250 \\
\hline LAFB & $32.8 \mathrm{ENE}$ & 100,000 & 300,000 & $1,075,840$ \\
\hline $\begin{array}{c}\text { Empire Machinery } \\
\text { Airstrip }\end{array}$ & $5.3 \mathrm{NNW}$ & 8,600 & $<100$ & 14,045 \\
\hline APS Helipad & Onsite & $1.000^{\text {(b) }}$ & $<50$ & na \\
\hline
\end{tabular}

Notes to Table 5.3-4: (a). $500 \mathrm{~d}^{2}$ for auports located between 5 and 10 miles: $10000 \mathrm{~d}^{2}$ for airports located more than 10 miles. $d$ is distance from plant in miles. (b). Estimated annual activity after PVNGS becomes operational. 


\section{Aircraft Hazards - Other Methods}

- Extension of NUREG-0800 Method

- Solomon, K.A., Analysis of Ground Hazard due to Aircraft and Missiles, RAND/P-7459, June 1988

$$
P(x)=(1 / 2)^{*} \gamma^{*} \operatorname{Exp}(-\gamma|x|)
$$

$\gamma$ crash density constant (per mile)

$x$ orthonormal distance from the intended path to the site

- Ove Arup \& Partners Hong Kong Ltd FAA Air Traffic Activity System (ATADS)

- Environmental Impact Assessment (EIA) Report 24037-REP-125-01

- Aircraft impact frequency for the Airport Fuel Tank Farm at the Hong Kong International Airport 


\section{Aircraft Hazards - Other Methods (Continue)}

\section{Ove Arup \& Partners (Continue)}

- Ove Arup \& Partners Hong Kong Ltd FAA Air Traffic Activity System (ATADS)

$$
\mathrm{F}=(\text { Crash Rate } X \mathrm{~N} X f(R, \theta)
$$

$x$ Proportion of flights in specified direction

$x$ Proportion of flights using specified runways

$x$ Target Area

Where

$$
f(R, \theta)=0.23 \operatorname{Exp}(-R / 5) \operatorname{Exp}(-\theta / 5)
$$

$\mathrm{R}=$ the Radial distance in kilometers from the runway end

$\theta=$ the angle in degrees between and runway centerline 


\section{Aircraft Hazards - Other Methods (Continue)}

- By V. A. Kostikov using the Poisson distribution method

- The probability of damage to an object on the ground in the case when the aircraft breaks up in flight

$$
P_{1}^{d}=\frac{S_{o b}}{S_{\text {fall }}^{1}} \frac{\sqrt{4 S_{o b} / \pi}}{\pi\left(L_{2}-L_{1}\right)}
$$

$S_{o b}=$ the area of the object;

$S_{\text {fall }}^{1}=$ the area over which the fragments of the aircraft are spread

$L_{1}$ and $L_{2}=$ the average distances over which the fragments (heavy and light) are carried 


\section{Aircraft Hazards - Other Methods (Continue) By V. A. Kostikov (continue)}

- The probability of damage to an object struck by an out-of-control aircraft

$$
P_{2}^{d}=\frac{S_{o b}}{S_{\text {fall }}^{2}} \frac{\sqrt{4 S_{o b} / \pi}}{2 \pi R_{a}}
$$

$S_{\text {fall }}^{2}=$ the area of the possible fall zone;

$S_{o b}=$ the area of the object;

$\mathrm{R}_{\mathrm{e}}=$ the radius of the accessible range, determined from ballistic properties of the aircraft, the flight altitude, and possible deviations from the flight path. 


\section{Aircraft Hazards References}

- NUREG-0800 Standard Review Plan for the Review of Safety Analysis Reports for Commercial Nuclear Power Plants, Rev. 4, US NRC, March 2010

- Solomon, K.A., Analysis of Ground Hazard due to Aircraft and Missiles, RAND/P-7459, June 1988

- Smith, R.E., Methodology for Calculation of the Probability of Crash of an Aircraft into Structures in Weapon Storage Areas, SAND/82-2409, February 1980

- US DOE, Accident Analysis for Aircraft Crash into Hazardous Facilities, DOE-STD-301496, October 1996

- Haley, T.A., Progression and Advancement of Aircraft Hazard Analysis Models, PSAM 4, Volume 3, 1998

- Phillips, D.W., "Criteria for the rapid assessment of the aircraft crash rate onto major hazard installations according to their location," United Kingdom Atomic Energy Report SRD/HSE R 435, 1987

- Kostikov, V. A., et. al., "Determination of the Probability of an Aircraft Falling on a Nuclear Power Plant," State Scientific Research Institute of Civil Aviation, FÉl, (translated from Atomnaya Énergiya, Vol. 74, No. 1, pp. 53-58, January, 1993)

- Berg, H.-P., "Risk Assessment of Aircraft Crash onto a Nuclear Power Plant," Bundesamt für Strahlenschutz, Salzgitter, Germany, RT\&A \# 01 (20) (Vol. 2), March 2011 


\section{Ground Transportation Accidents (Road, Railroad, and Waterway)}

- Transportation accident resulting in an explosion, missiles generated by an explosion and/or release of hazardous materials.

- Hazards associated with transportation accidents (on roads, railroads, and waterways) must be reviewed and reevaluated using current data: types of hazardous materials, number of shipments of hazardous materials, vehicle accident rates, etc.

- NUREG/CR-5042, "Evaluation of External Hazards to Nuclear Power Plants in the United States," Lawrence Livermore National Laboratory, December 1987.

- NUREG/CR-5042, Supplement 1, "Evaluation of External Hazards to Nuclear Power Plants in the United States, Seismic Hazards" Lawrence Livermore National Laboratory, April 1988.

- NUREG/CR-5042, Supplement 2, "Evaluation of External Hazards to Nuclear Power Plants in the United States, Other External Events," Lawrence Livermore National Laboratory, February 1989. 


\section{Elements of Transportation Risk Evaluation due to Releases}

- Frequency of transportation accident within 5 miles of plant is dependent on:

- Vehicle hazard distance, $L$, which is distance traveled by vehicle within 5 miles of plant.

- Number of vehicles travel on road/railroad/waterway per year.

- Vehicle accident rate (per vehicle-mile).

- Proportion of the vehicles carrying hazardous materials involved in accidents that results in releases.

- Probability of diffusion of hazardous materials from accident site towards the plant.

- Probability of control room not isolated from the hazardous materials released from the accident site.

- 2,973 billion miles per year and 5.6 million crashes per year 


\section{Calculation of Hazard Distance (L)}

\section{Idaho National Laboratory}

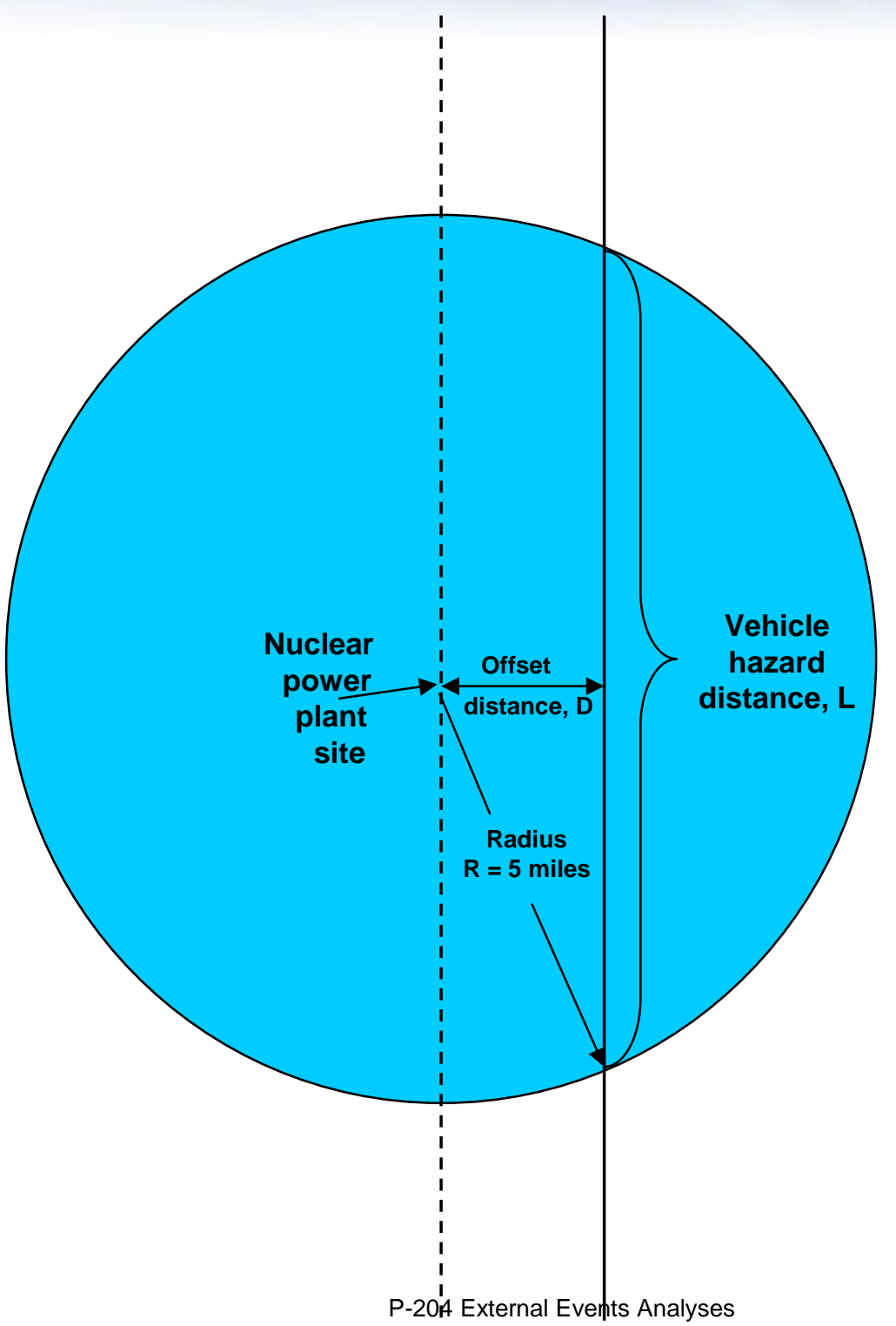

$R^{2}=\left[\frac{L}{2}\right]^{2}+D^{2}$

$25=\frac{L^{2}}{4}+D^{2}$

$L=\left(100-4 D^{2}\right)^{1 / 2}$ 


\section{Travel Statistic}

\section{Data from Traffic Safety Facts Research}

- Total miles driven = 2,973 Billion

- Total Accident = 5.6 Million (fatal, non-fatal, property damage)

- Rate of Accident $=5.6 \mathrm{E} 6 / 2.973 \mathrm{E} 12=1.9 \mathrm{E}-6 / \mathrm{mile}$ 


\section{Other Transportation Accident Modes}

- Vehicle hitting a plant structure or offsite structure.

- Truck traffic movement within the plant boundaries is controlled and infrequent.

- Ship or barge colliding with intake structure. 


\section{Pipeline (Oil and Gas) Accidents}

- Hazards associated with pipeline accidents:

- Release of hazardous materials towards the plant.

- Pressure waves from explosion cause damage to plant.

- Debris or missile generated from explosion cause damage to plant.

- Only high pressure pipelines going through or near the plant exclusion area pose a threat to the plant. 


\section{Nearby Industrial/Military Facilities Accidents}

- Examples of accidents are:

- Chemical plant fires and/or explosions.

- Munitions plant explosions and/or fire.

- Effect of accidents on power plants similar to that of transportation accident.

- Explosion overpressure causing damage to the plant.

- Debris and missiles causing damage to the plant.

- Hazardous materials release towards plant.

- For plants located near industrial sites, industrial accidents were considered in the licensing of the plant.

- Evaluate the impact of new industries (built since the issuance of $O L$ ) in the vicinity of plant. 


\section{On-Site Storage of Hazardous and Explosive}

Materials

- Examples of hazardous and explosive materials at the site:

- Chlorine, hydrazine, etc.

- Hydrogen tanks, propane tanks, etc.

- Release of hazardous materials affect control room habitability.

- Explosion may cause damage to safety-related structure, equipment, etc.

- Evaluation required for issuance of operating license.

- Changes since the issuance of OL must be evaluated. 


\section{Other External Events}

- Lightning

- Primary impact of lightning is loss of offsite power.

- May affect safety-related equipment and cause reactor trip.

- Unlikely to affect onsite power and other safety system.

- Impact may be bounded by loss of offsite power or reactor trip events.

- Need to review site-specific lightning events to confirm impact of lightning.

- Five lightning events through December 2010 (LERs) resulted in LOOP events 


\section{Other External Events (continued)}

- Severe Temperature Transients (Extreme Heat, Extreme Cold)

- May impact the capacity of Ultimate Heat Sink and offsite power supply.

- May also freeze instrument lines.

- NUREG-1407 concluded that events need not be addressed in IPEEE.

- Need to review site specific events and impact.

- Severe Weather Storm (Ice Storms, Hail Storms, Snow Storms, Dust/Sand Storms)

- May cause loss of offsite power.

- NUREG-1407 concluded events need not be addressed in IPEEE.

- Need to review site specific events and impact. 


\section{Other External Events (continued)}

- Example of Evaluation of Dust and Sand Storm for PVNGS

- Performed dust concentration evaluation.

- Dust buildup on switchyard insulators reduced by insulator configuration in transmission lines. Little contribution to line outage frequency from dust storm.

- Design of diesel generator and control room ventilation and diesel generator intake and exhaust system adequate in protecting dust and sandstorms.

- The UHS is adequately designed against dust and sandstorm.

- Essential HVAC and control room HVAC systems are adequately designed against dust and sand storm. 


\section{Other External Events (continued)}

- External Fires (Forest Fires, Grass Fires)

- Fires occurring outside the plant site boundary.

- May cause loss of offsite power and forced plant ventilation isolation.

- Unlikely to spread onsite.

- NUREG-1407 concluded that events need not be addressed in IPEEE.

- Only one event reported; LOOP due to external fire.

- Extraterrestrial Activity (Meteorite Strikes, Satellite Falls)

- Probability of a meteorite strike is insignificant.

- NUREG-1407 concluded that events need not be addressed in IPEEE based on its low initiating event frequency. 


\section{Extraterrestrial Activity}

- \# of Meteorite Strikes - 2 in 100 yrs

- Area of Impact $=500 \mathrm{mi}^{\wedge} 2$

- Surface Area of Earth = 2E8 mi^2

Impact probability at site = ? 


\section{Other External Events (continued)}

- Volcanic Activity

- Active volcanoes in the continental U.S. are located in the Cascade mountain range.

- Trojan and Columbia could be affected by volcanic activity.

- Potential impacts include forced plant ventilation isolation, debris in the UHS, and ash fall accumulation on roof top. 


\section{Other External Events (continued)}

- Example of Volcanic Activity Evaluation for Columbia

- Columbia is located $165 \mathrm{~km}$ from Mt. Adams and $220 \mathrm{~km}$ from Mt. St. Helens.

- Major threat from volcanic eruption is from the ash fall.

- A review of the plant design was conducted after the eruption of Mt. St. Helens in 1980; Columbia was under construction.

- Procedures were written for implementation in the event of volcanic eruption. 


\section{Columbia Design Basis Ash Fall Parameters}




\section{Design Basis Ash Fall Parameters}

\begin{tabular}{|c|c|c|c|}
\hline Parameter [Units] & $\begin{array}{c}\text { Mt. St. } \\
\text { Helens } 1980\end{array}$ & FSAR & SER \\
\hline Maximum Ash fall [in] uncompacted & 2.75 & 5.00 & 7.4 \\
\hline Maximum Ash fall [in] compacted & 1.65 & 3.00 & 3.00 \\
\hline Ash fall Duration [hrs.] & 20 & 20 & 20 \\
\hline Ash fall Rate [in/hr] Average & 0.14 & 0.25 & 0.35 \\
\hline Ash fall Rate [in/hr] Maximum & 0.21 & 0.35 & 0.44 \\
\hline Average Grain Size $[\mu \mathrm{m}]$ & 75 & 75 & 75 \\
\hline Density $\left[\mathrm{b} / \mathrm{ft}^{3}\right]$ compacted & 96 & 96 & 96 \\
\hline Compaction [\%] & 40 & 40 & 60 \\
\hline Air Concentration $\left[\mu \mathrm{gm} / \mathrm{m}^{3}\right]$ Average & 69,795 & 124,634 & 174,488 \\
\hline Air Concentration $\left[\mu \mathrm{gm} / \mathrm{m}^{3}\right]^{\prime}$ Maximum & 104,693 & 155,793 & 219,536 \\
\hline
\end{tabular}




\section{Concluding Observations}




\section{Concluding Remarks on Other External Events}

- Newer plant and facilities design meets the 1975 SRP criteria.

- Older plant design were evaluated to determine if it meets the 1975 SRP criteria.

- Identify and evaluate significant changes at the site, if any, since OL issuance that affect original design conditions. 


\section{Insights from HFO IPEEE Review}

- Level of analysis varied widely from plant to plant (from simplistic screening methods to PRA/bounding analysis).

- Most of the HFO IPEEE studies used qualitative screening method.

- None of the submittals identified a vulnerability.

- CDF from high winds/tornadoes varies from 6E-5 to 2E-7/yr. CDF from external flooding varies from 7E-6 to $2 \mathrm{E}-8 / \mathrm{yr}$.

- Many submittals just used the IPE CCDP, given LOSP and loss of service water without modeling the specific significant impacts of high winds or floods. CDF may be underestimated.

- Risk associated with high winds and external floods for those plants located in coastal areas or along rivers is of concern for a few plants.

- Potential failures of upstream dams leading to flooding of the plant site were considered in a few submittals. 


\section{Insights from HFO IPEEE Review (continued)}

- Given the large uncertainties in the site specific hazard curves for external floods, screening may have been premature in some cases. A flood level just a few inches (or less) below the failure-incipient level might have a frequency of one or two orders of magnitude greater than the hazard for the failure-incipient level.

- High winds and external floods have motivated improvements at certain plant sites. External floods accounted for about $50 \%$ of the plant improvements.

- Some licensees implemented plant modifications/procedural changes (flood protection at entry pathways, door seals, sandbagging, etc.).

- Accidents related to transportation and nearby facilities have been screened out in all of the IPEEE submittals.

- Plant-unique hazards such as lightning (8E-6/yr) and snow/ice loads (7E-6/yr) were reported in one submittal to result in non-negligible risk. Chemical release from a nearby facility $(8 \mathrm{E}-6 / \mathrm{yr})$ was reported in another submittal. 


\section{Key Background Documents for Other External Events}

- NUREG-75/087, "Standard Review Plan for the Review of Safety Analysis Report for Nuclear Power Plants," December 1975 (Updated SRP NUREG0800, July 1981).

- NUREG/CR-2300, "PRA Procedures Guide," January 1983

- NUREG/CR-4839, "Methods for External Event Screening Quantification: Risk Methods Integration and Evaluation Program (RMIEP) Methods Development," March 1992.

- NUREG/CR-5042, "Evaluation of External Hazards to Nuclear Power Plants in the United States," December 1987.

- NUREG/CR-5042, Supplement 2, "Evaluation of External hazards to Nuclear Power Plants in the United States, Other External Events," February 1989.

- NUREG-1407, "Procedural and Submittal Guidance for the Individual Plant Examination of External Events (IPEEE) for Severe Accident Vulnerabilities," Final Report, June 1991.

- NUREG-1742, "Perspectives Gained from the Individual Plant Examination of External Events (IPEEE) Program," April 2002

- ANSI/ANS-58.21-2007, "External Events PRA Methodology Standard," March $1,2007$. 


\section{Seismic Risk Assessment}




\section{Learning Objectives}

- After studying this section you should be able to:

- Describe fundamental differences between the seismic PRA and seismic margin approaches.

- Define key terms such as hazard curve, fragility curve, and HCLPF.

- Understand how seismic PRA and seismic margin methodology and procedures can be used in risk informed applications. 


\section{Outline of Seismic Analysis Presentation}

- Seismic Analysis Methods Overview

- Terminology

- Seismic Margin Approach

- Seismic Hazard Evaluation

- Seismic Fragility Evaluation

- Plant System and Sequence Analysis

- Example Results 


\section{Seismic Analysis Approach}

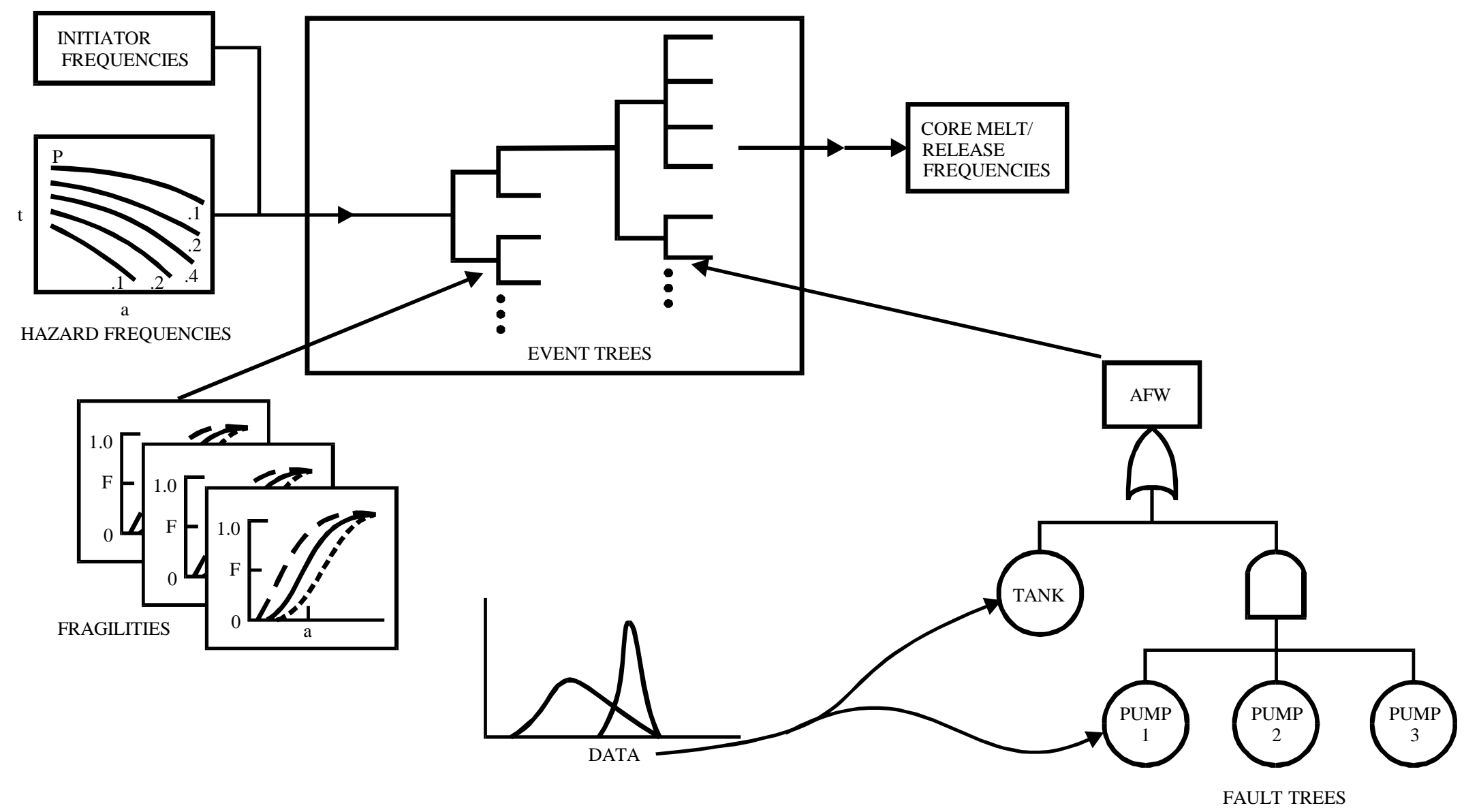




\section{Terminology}

- Hazard Curve

- A monotonically decreasing curve indicating the frequency per unit time of an external event of a specified severity or greater occurring at a specific site; most often used for earthquakes and high winds; only one parameter is used to describe the event severity.

- Hazard Curve Family

- A discrete set of hazard curves that represents the uncertainty in the assessed hazard, each curve is assigned a probability of being the true representation of the hazard; the sum of the assigned weights add to 1 ; usually 10 or fewer curves in the set. 


\section{Seismic Hazard Curves}

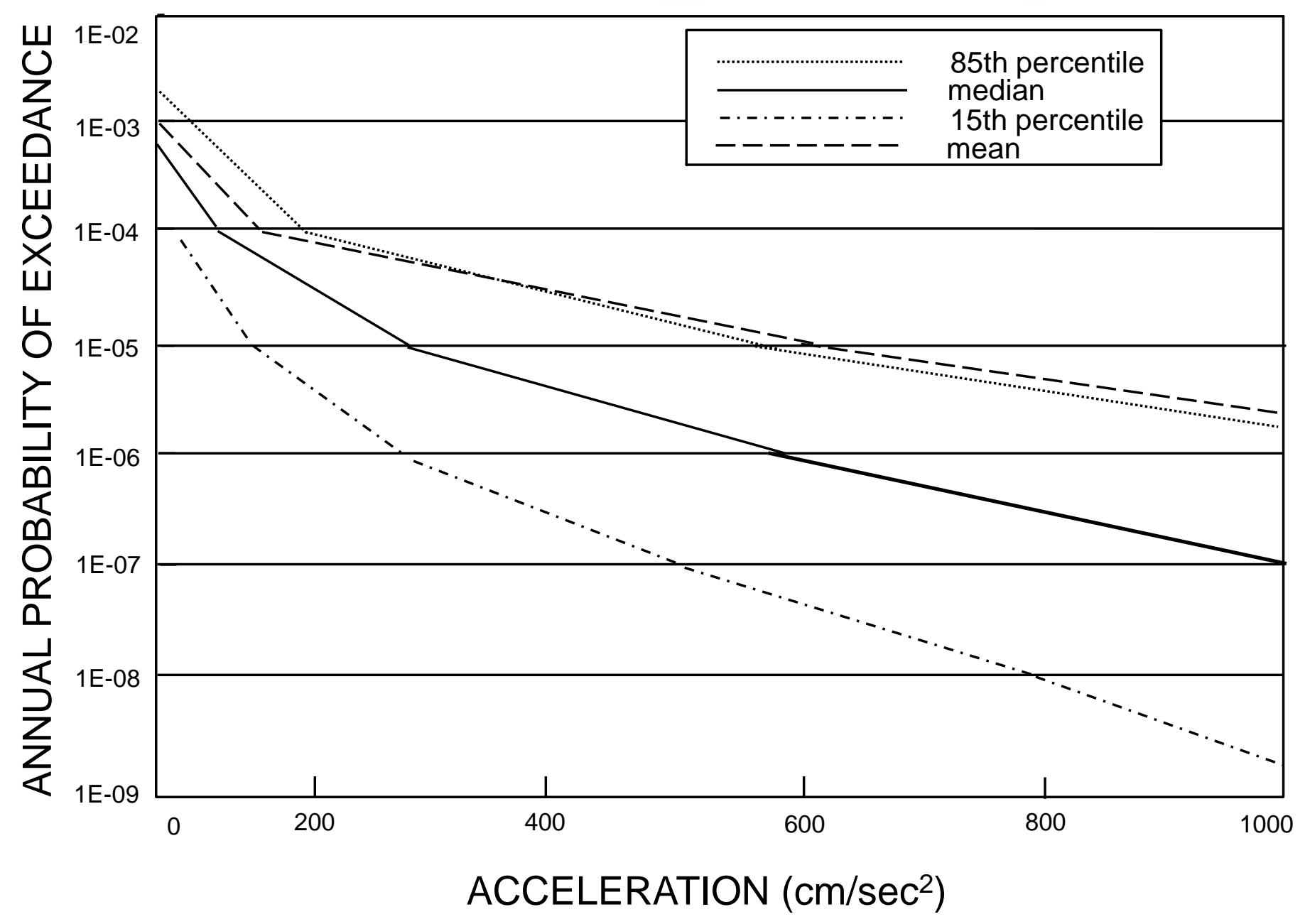




\section{Terminology (Continued)}

- Response Spectrum

- A plot of natural (harmonic) frequency vs. spectral acceleration, velocity or displacement signifying the response of a single degree of freedom system to the earthquake ground motion.

OR

- A response spectrum is simply a plot of the peak or steady-state response (displacement, velocity or acceleration) of a series of oscillators of varying natural frequency, that are forced into motion by the same base vibration or shock. 


\section{Response Spectrum and Model}

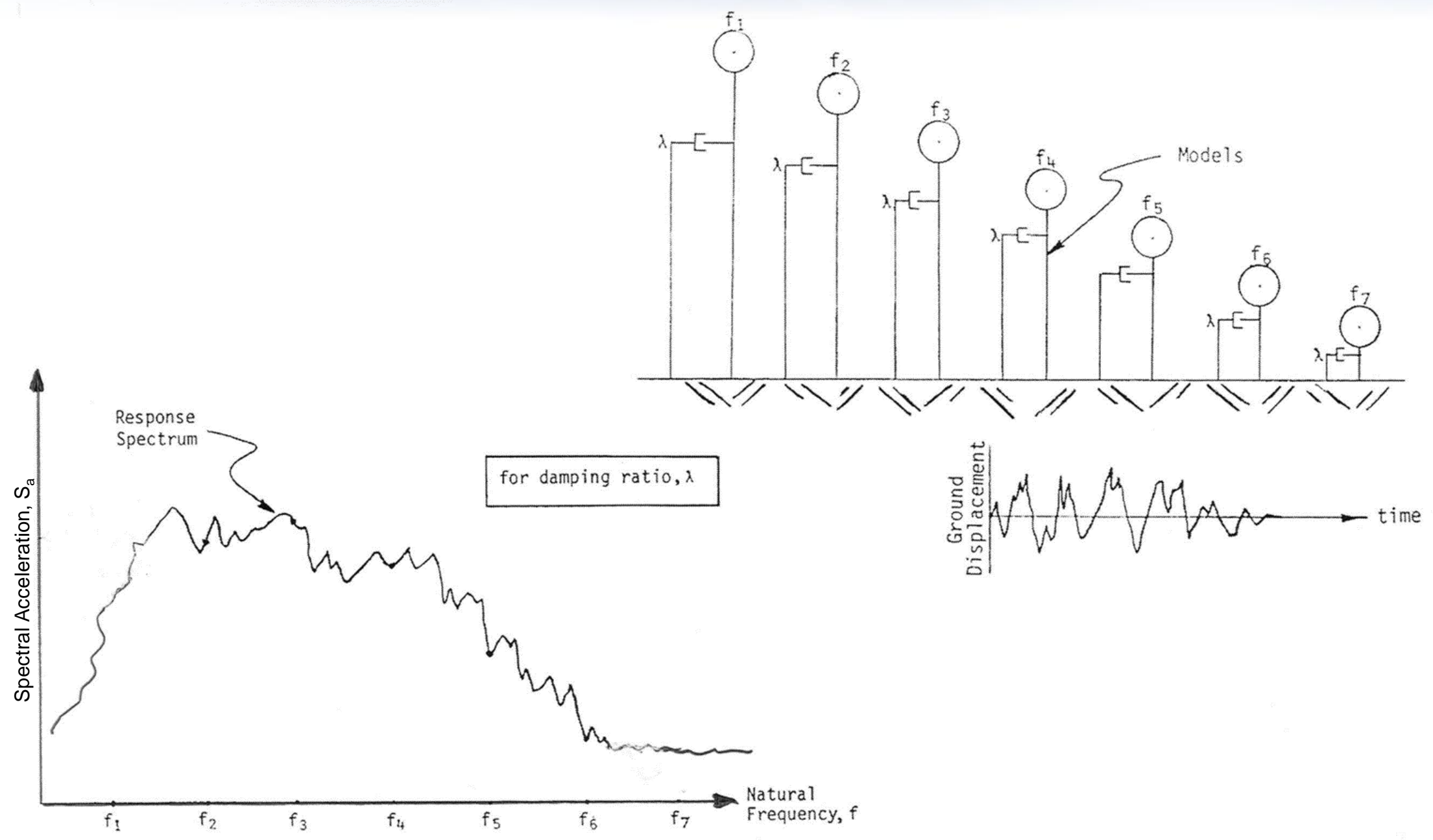




\section{Response Spectra Assessment}

- Considers soil-structure interactions

- Reflects the damping and/or amplification effects

- Used to produce the Hazard Spectrum

- Not only magnitude of motion, but also harmonic-frequency of motion

- Spectra (harmonic-frequency) can be an important consideration when estimating SSC fragilities 


\section{Both Stress and Strength Info Needed}

- Hazard curves represent stress on the plant

- Strength of plant systems, structures and components is also needed

- Strength of SSC described as Fragility

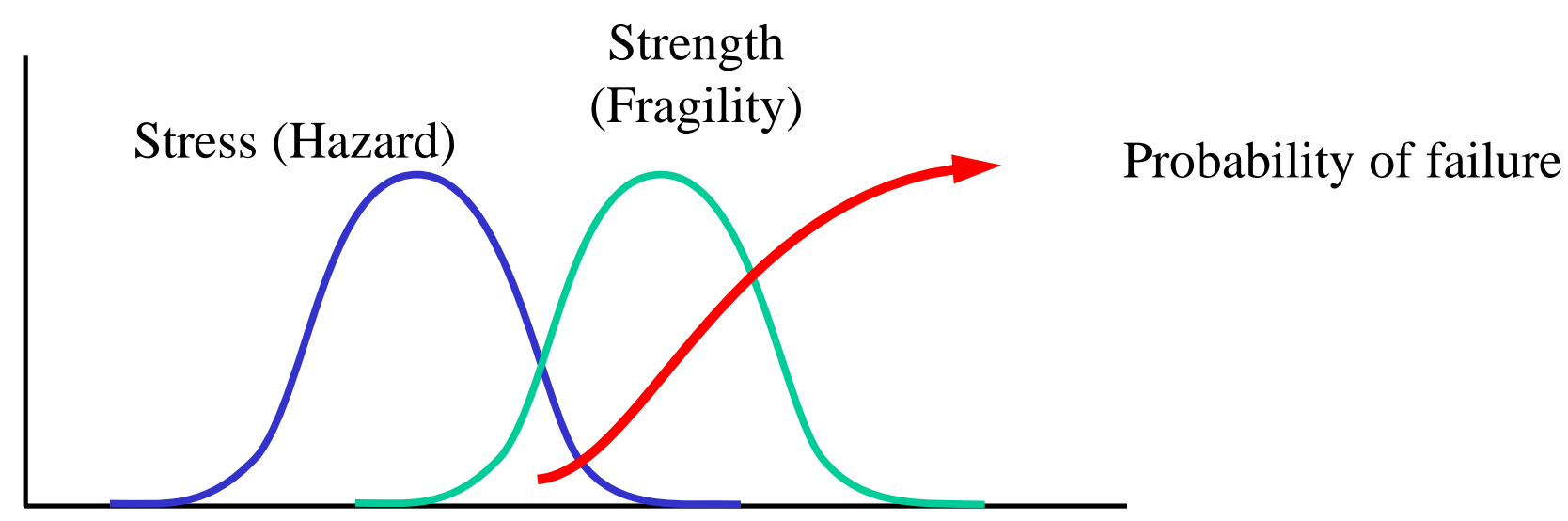




\section{Terminology (Continued)}

- Fragility Curve

- A monotonically increasing curve indicating the chances of failure of a single structure or component as a function of external event severity; most often used for earthquakes and high winds, event severity is represented by the same parameter used to develop the hazard curve.

- Fragility Curve Family

- A continuum of fragility curves that describe the uncertainty in the assessed structure or component fragility; the curves are identified by the cumulative probability of being the correct or at least a conservative curve; e.g., 95\% curve. 


\section{Component Fragility Curves}

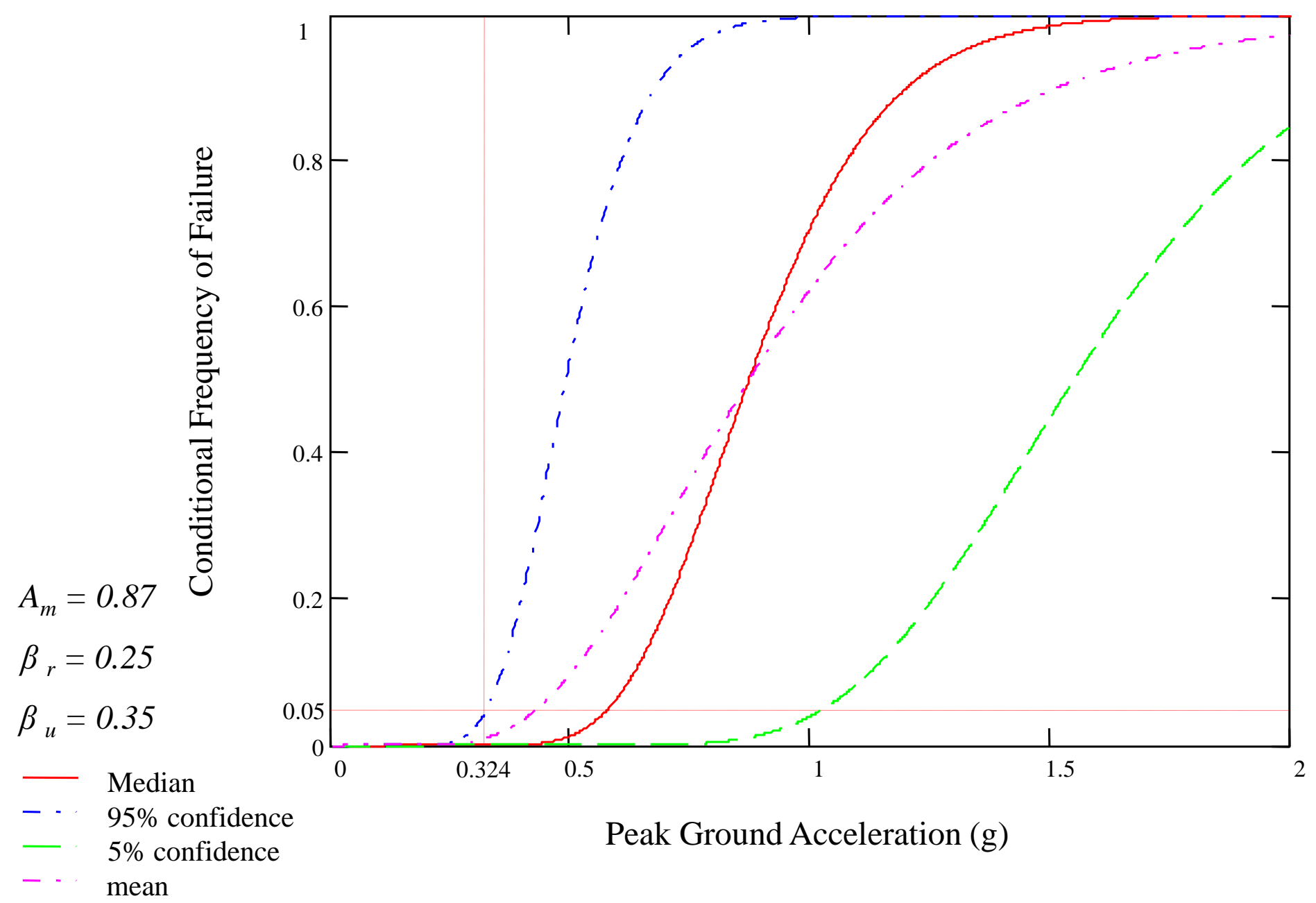




\section{Seismic Hazard Analysis}




\section{Seismic Analysis Approach}

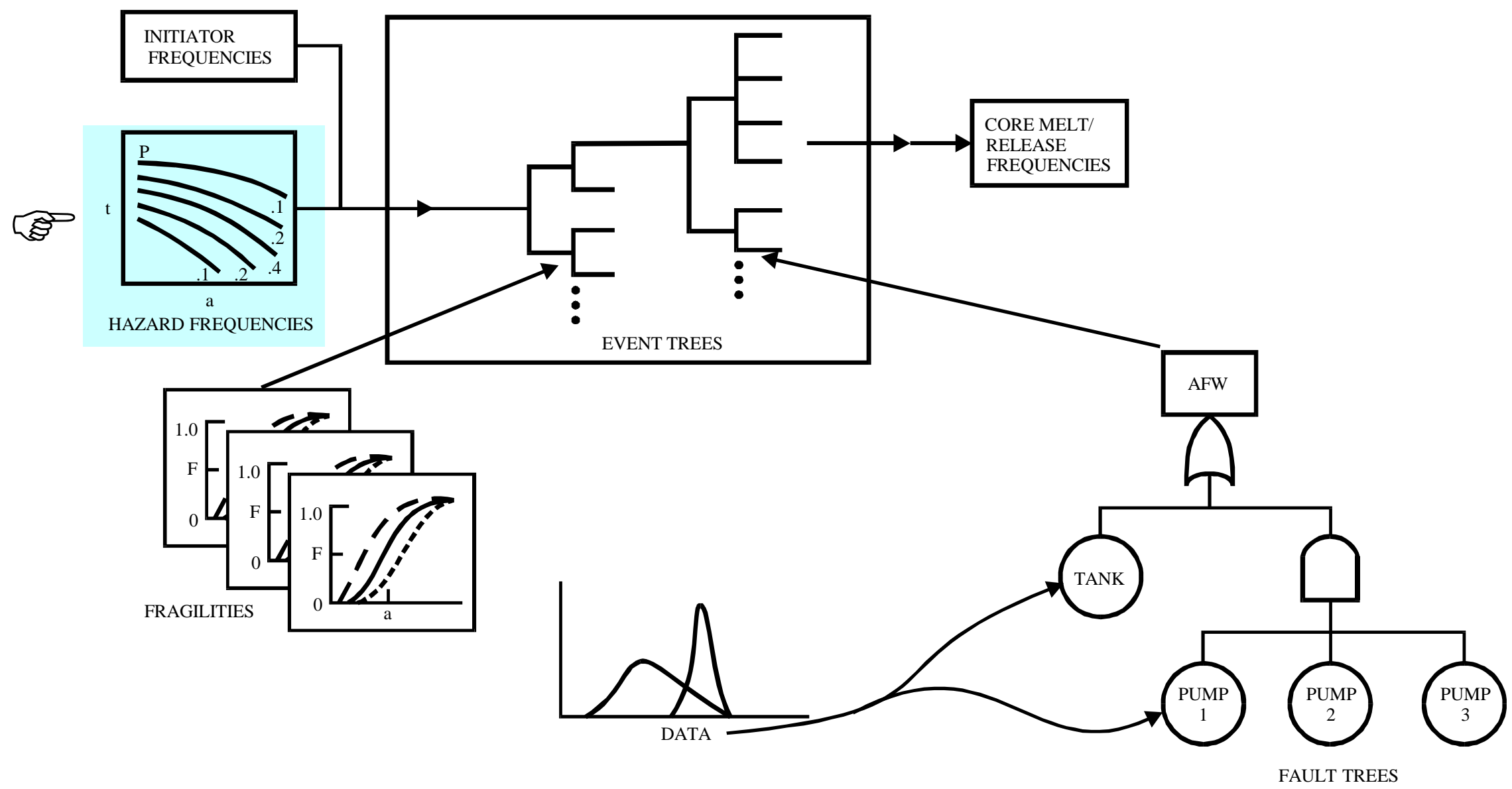




\section{Seismic Hazard Analysis (cont.)}

- Deductive Methods

- Earthquake occurrence model deduced from:

- Tectonic Theories

- Geologic Evidence

- Analogies with Other Regions

- Historical Seismicity

- Typical method for PRA 


\section{Estimating Seismic Hazard}

- Historical Methods

- Recreate ground motions at the site over historical times.

- Translate recreated observations into annual probabilities of exceedance.

- Extrapolate probabilities to high amplitude of ground shaking.

- Shortcomings - large uncertainties not fully quantified. 


\section{Seismic Hazard for IPEEE}

- Extensive Research by USNRC and EPRI Hazard Quantified for Eastern U.S. sites

- NUREG/CR-5250 (1989)

- NUREG-1488 (1994)

- EPRI NP-6395-D (1989)

- Western Sites Required (by IPEEE) Independent Site Specific Studies for PRA

- USGS study (2008) 


\section{Site-Specific Seismic Hazard Estimation}

- Develop the probability/year of exceeding a given estimator of ground motion, such as peak ground acceleration or pseudo-relative velocity ${ }^{a}$

- At a given probability/year, develop the equally-weighted spectral shape known as a uniform hazard spectrum

a. A computational approximation to the response spectrum 


\section{Four Basic Steps to the Methodology}

- Step 1 - Identify seismic sources (or source zones)

- Step 2 - For each source, develop a model describing the expected frequency as a function of magnitude.

- Step 3 - For each source, develop a model describing the expected value of a ground-motion parameter as a function of $(M, D)=$ (magnitude, distance from the source).

- Step 4 - Integrate among the sources to form a seismic hazard curve. 


\section{Seismic Hazard Development}

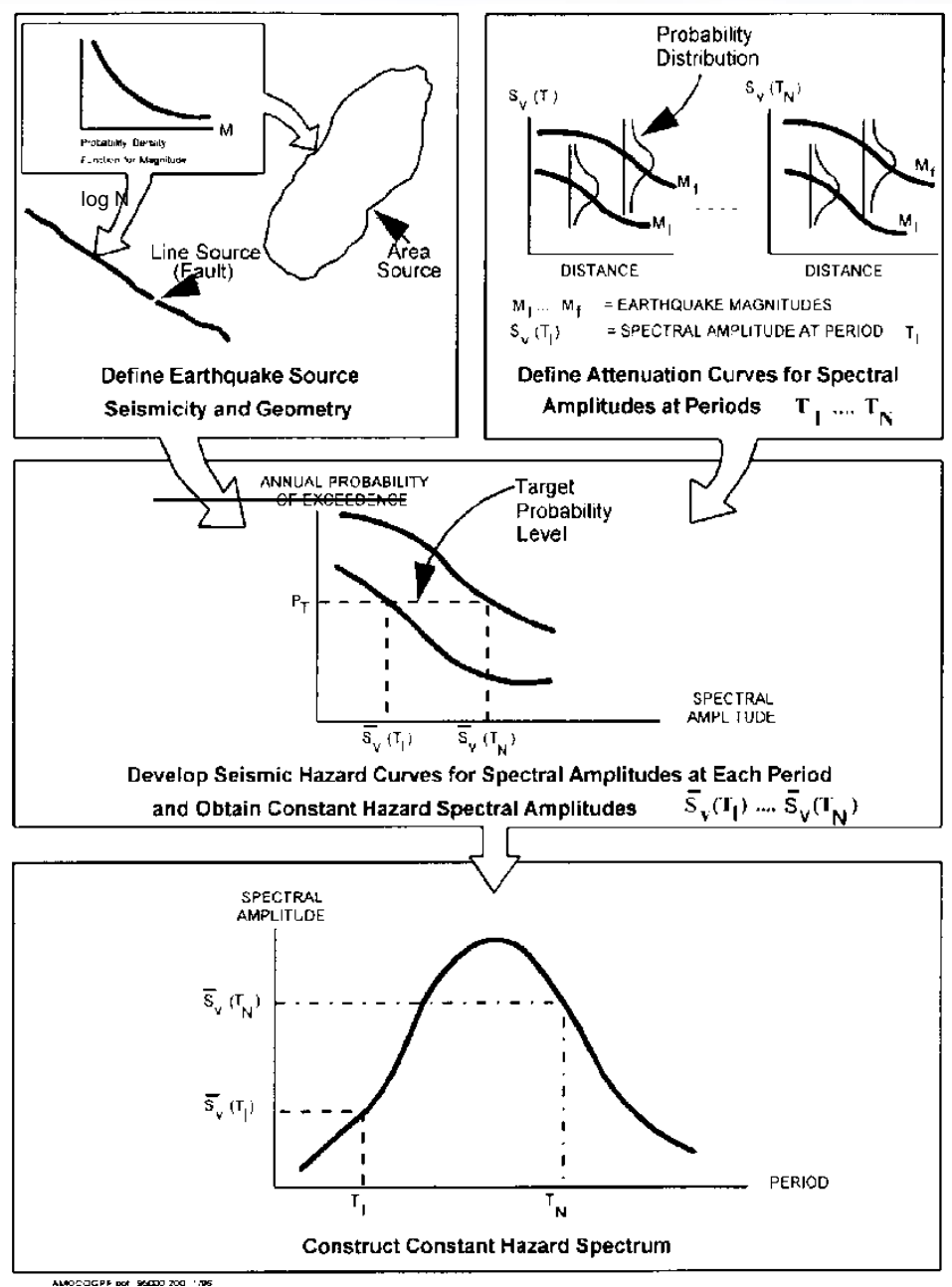




\section{Seismic Hazard Curve Determination}

- Integrates the contribution of all possible earthquakes and calculates the probabilities that selected ground motion parameter will be exceeded.

$$
P[A>a] \text { year }=\Sigma v \int P[A>a \mid m, d] f(m) f(d) d d d m
$$

- Seismic hazard curves - annual frequency of exceedence versus specified ground motion parameter. 


\section{Seismic Hazard Described 3 Ways}

- Peak Ground Acceleration (PGA)

- Spectral Acceleration (SA)

- Uniform Hazard Spectra (UHS) 


\section{Ground Motion Estimation (Continued)}

- Ground Motion Parameters

- Peak Ground Acceleration (PGA) - is a measure of earthquake acceleration on the ground and an important input parameter for earthquake engineering, also known as the design basis earthquake ground motion (DBEGM).

- Spectral Acceleration (SA) - Spectral acceleration (SA) is a unit measured in $g$ (the acceleration due to earth's gravity, equivalent to g-force) that describes the maximum acceleration in an earthquake on an object specifically a damped, harmonic oscillator moving in one physical dimension. This can be measured at (or specified for) different oscillation frequencies and with different degrees of damping although $5 \%$ damping is commonly applied. ${ }^{111}$ The SA at different frequencies may be plotted to form a response spectrum. 


\section{Annual Probability of Exceeding a Peak Ground Acceleration}

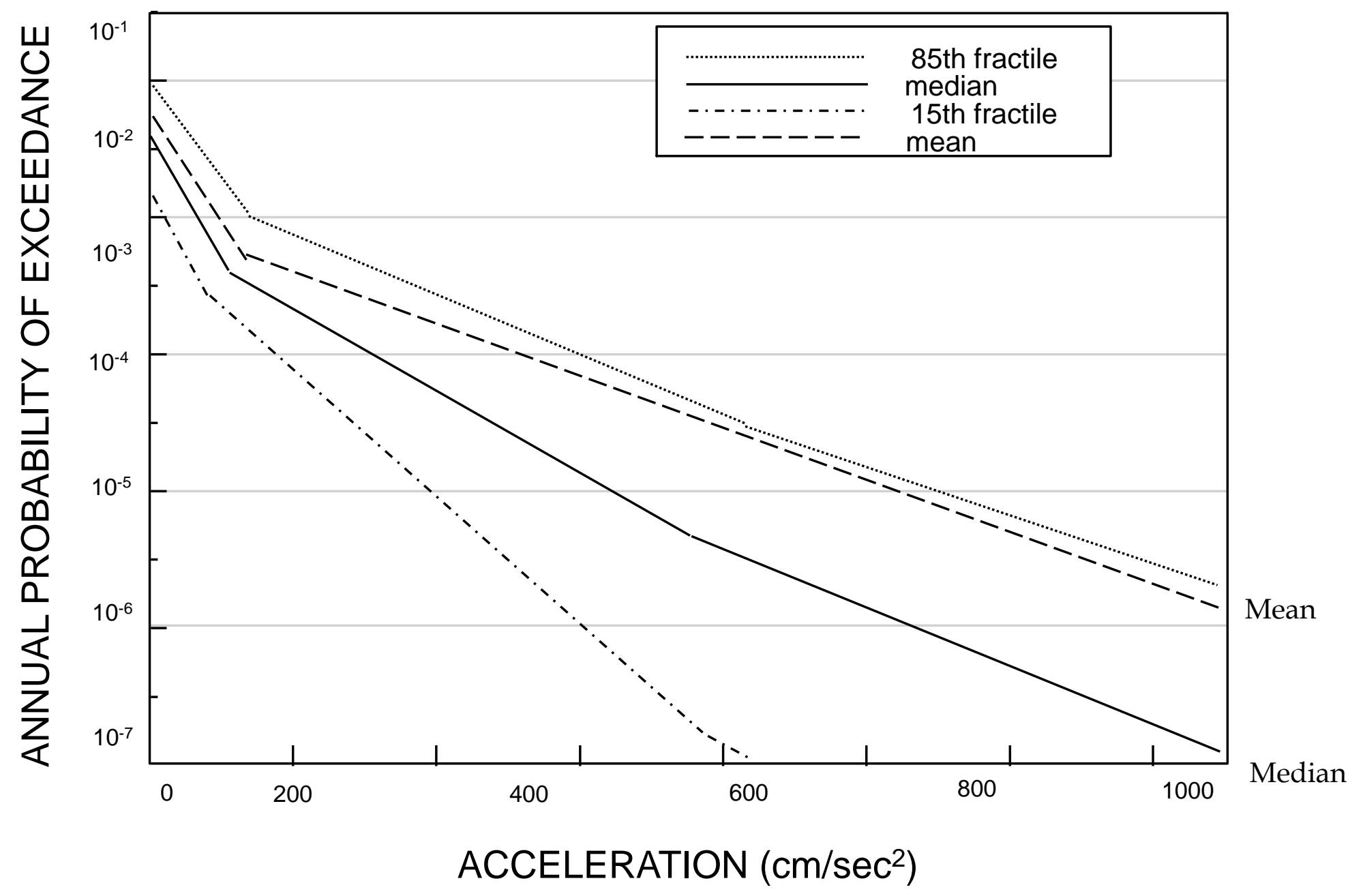




\section{Ground Motion Estimation (Continued)}

- Ground Motion Parameters

- Peak Ground Acceleration (PGA) - is a measure of earthquake acceleration on the ground and an important input parameter for earthquake engineering, also known as the design basis earthquake ground motion (DBEGM).

- Spectral Acceleration (SA) - Spectral acceleration (SA) is a unit measured in $g$ (the acceleration due to earth's gravity, equivalent to g-force) that describes the maximum acceleration in an earthquake on an object specifically a damped, harmonic oscillator moving in one physical dimension. This can be measured at (or specified for) different oscillation frequencies and with different degrees of damping although $5 \%$ damping is commonly applied ${ }^{111}$ The SA at different frequencies may be plotted to form a response spectrum. 


\section{0-year Return Period}

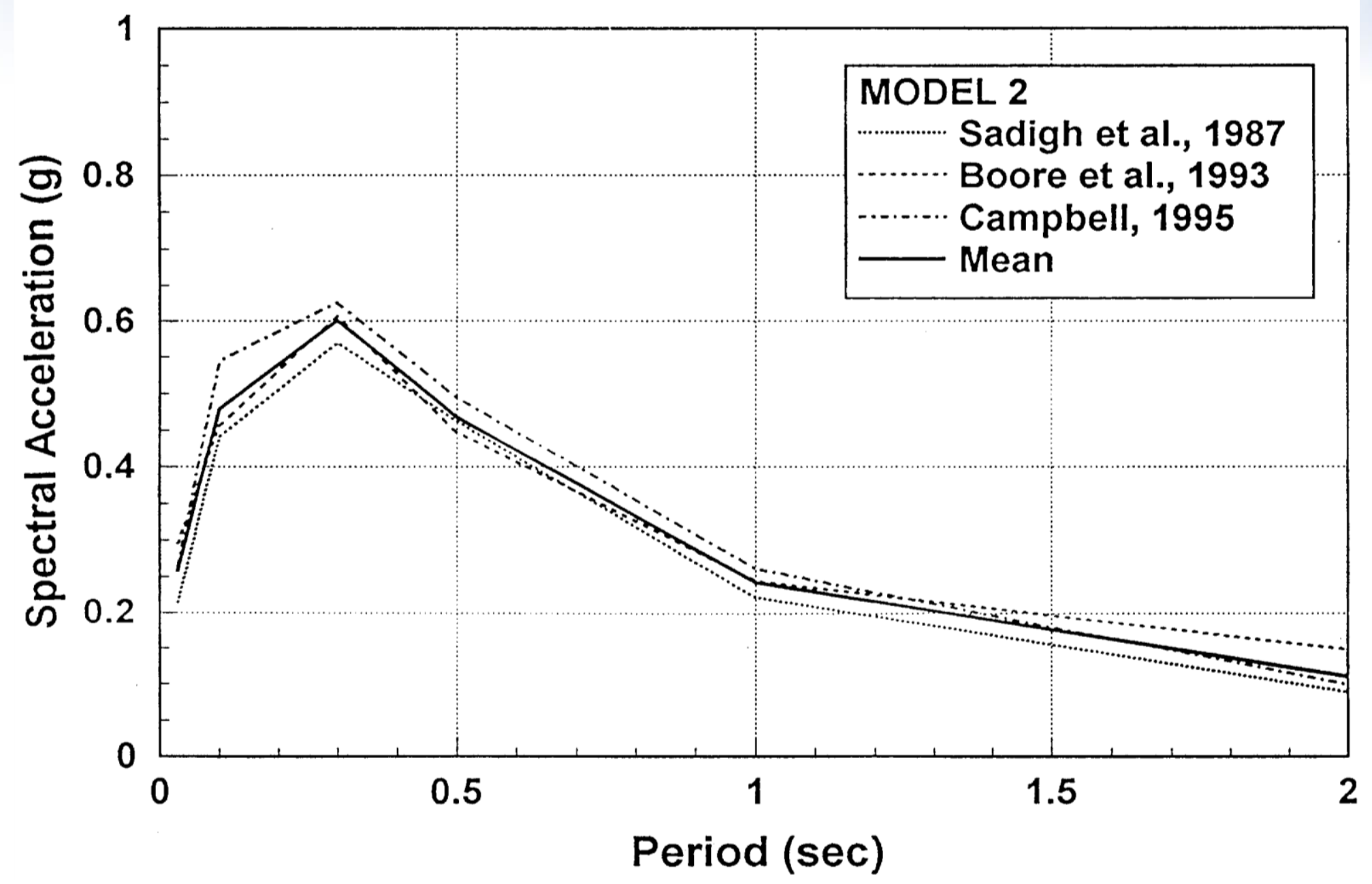

Calculated 5\%-damped acceleration response spectra with a return period of 10,000-years for Earthquake Source Zonation Module 2. 


\section{Ground Motion Estimation (Continued)}

- Pros and cons of using spectral acceleration:

- Better indicator of damaging potential of earthquake.

- Reduced uncertainty in spectral amplitudes.

- Ground motion estimates have to be done at several frequencies.

- Additional effort.

- Need to be consistent with what is used in fragility evaluation. 


\section{Uniform Hazard Spectra For the 10-4 Annual Probability of Exceedance}

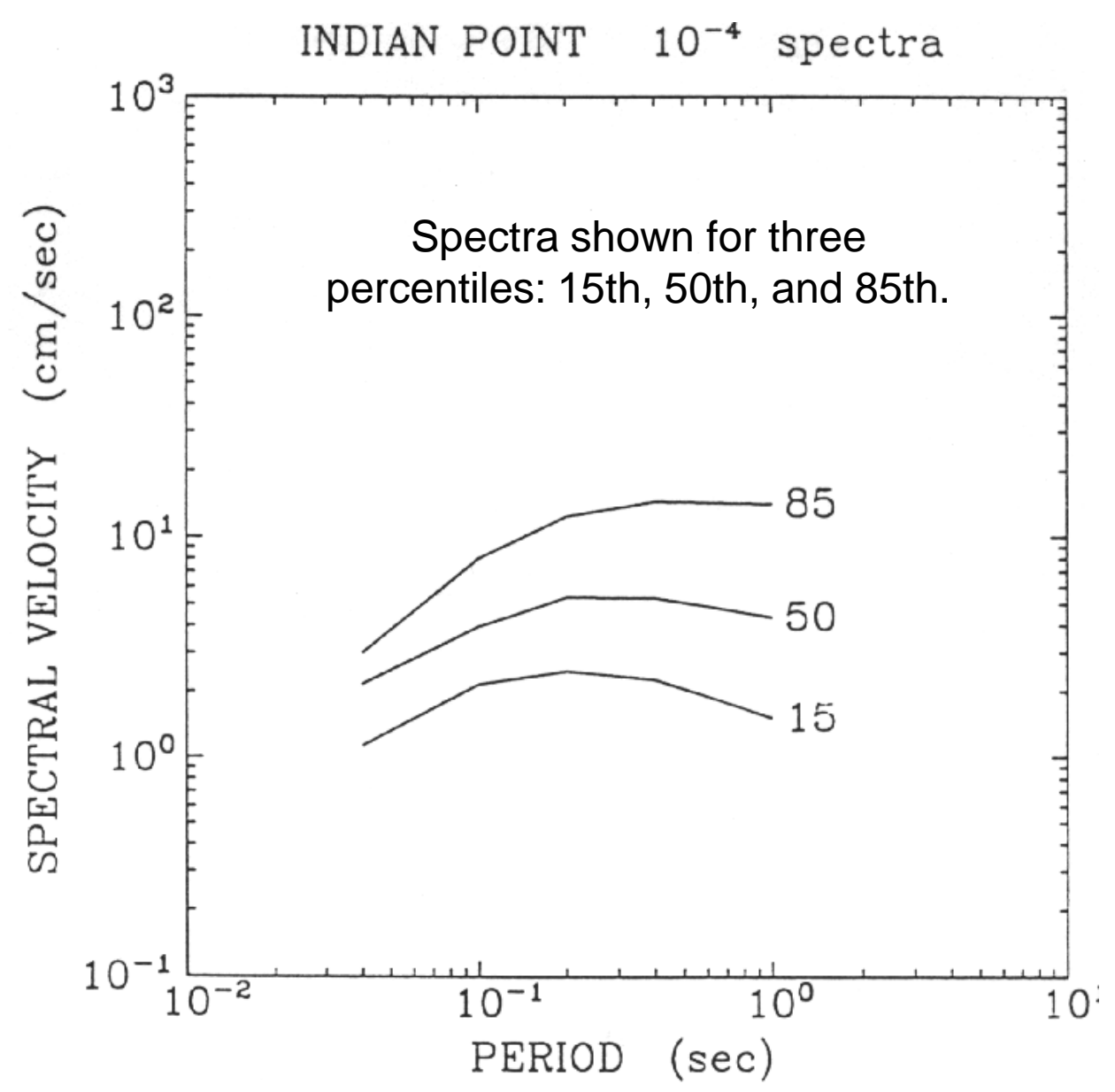




\section{Seismic Fragility Evaluation}




\section{Seismic Analysis Approach}

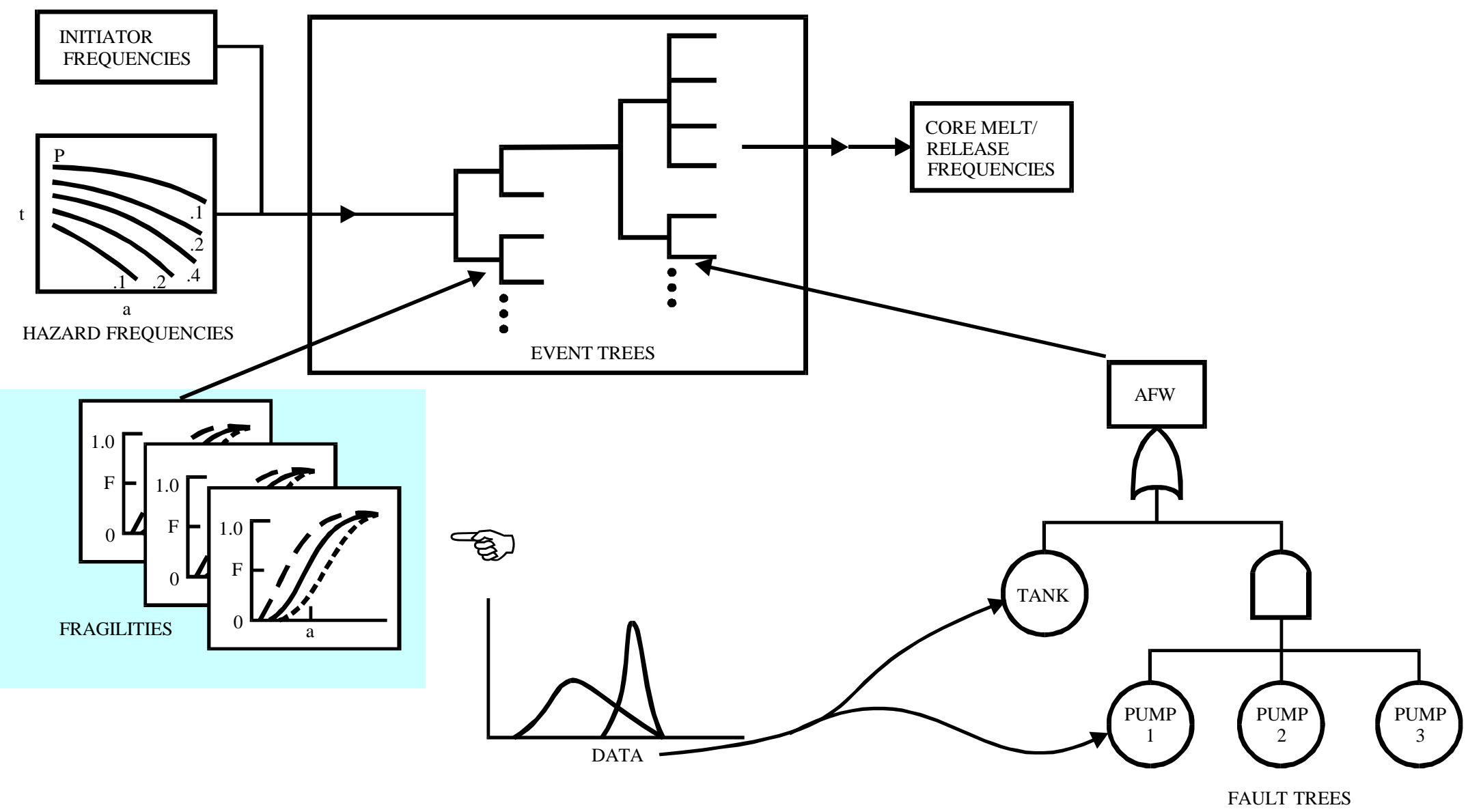




\section{Learning Objectives}

- After studying this section, you should be able to understand the concept of fragility curves sufficiently to:

- Understand the difference between a single fragility curve and a family of fragility curves.

- Understand the lognormal representation of fragility curves

- Understand the definition and significance of a HCLPF. 


\section{Component Fragilities}

- Conditional probability of failure for a given response value, or earthquake level

- Requires clear definition of failure and its consequences

- Several failure modes may be of interest.

- Generally component loses functional capability before pressure boundary fails

- Screening used to limit required number of fragility curves

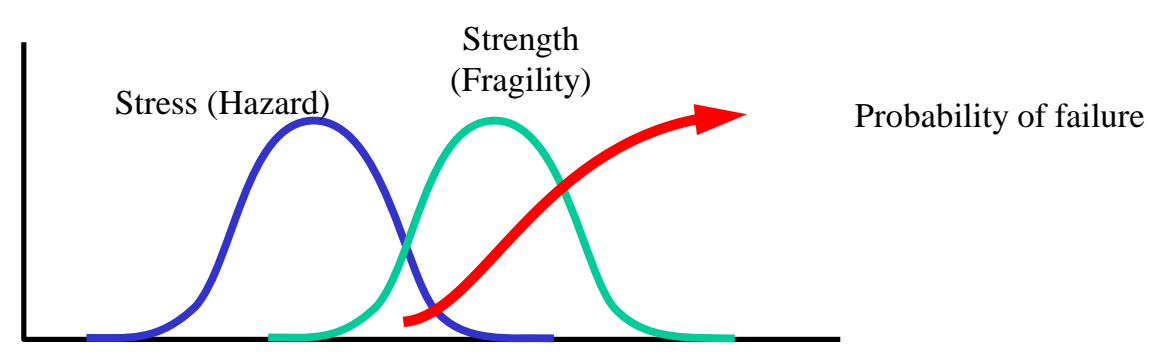




\section{Fragility Evaluation for Equipment}

- Variables Considered:

- Strength

- Inelastic energy absorption

- Spectral shape

- Damping

- Modeling

- Method of analysis/testing

- Combination of modes

- Combination of earthquake components

- Structural response

- Soil-structure interaction

- Ground Motion Incoherence 


\section{Fragility Model}

- Log normal model (all properties of variables have log normal distribution).

- Entire fragility curve $(A)$ and its uncertainty expressed by three parameters $\left(A_{M}, \beta_{R}, \beta_{U}\right)$.

$$
A=A_{m} \beta_{R} \beta_{U}
$$

where

$A=$ ground acceleration corresponding to any given frequency of failure.

$A_{m}=$ median ground acceleration capacity.

$\beta_{\mathrm{R}}, \beta_{\mathrm{U}}=$ random variables with unit median and logarithmic standard deviation $\beta_{\mathrm{R}}, \beta_{\mathrm{U}}$.

$\beta_{\mathrm{R}}, \beta_{\mathrm{U}}$ represent inherent randomness about the median and uncertainty in the median value, respectively. 


\section{Fragility Derivation}

- Inherent Randomness, Aleatory Uncertainity $\left(\beta_{R}\right)$

Primarily associated with earthquake characteristic (i.e. response spectra shape and amplification, duration, number and phasing of peaks)

Not considered possible to significantly reduce randomness by additional analysis or test

Procedures to assure no double counting of aleatory uncertainty in ground motion

- Modeling Uncertainty, Epistemic Uncertainty $\left(\beta_{\cup}\right)$

Associated with lack of knowledge of model and parameters

Can be reduced by additional analyses and tests 


\section{Fragility Derivation}

- Usually, fragility is extrapolated from design information by quantifying factors of conservatism and variability

$$
\begin{aligned}
& A_{m}=F_{C} F_{R E} F_{R S} A_{S S E} \\
& \text { Where: } \\
& F_{C}=\text { capacity factor (strength and ductility) } \\
& F_{R E}=\text { response factor for equipment } \\
& F_{R S}=\text { response factor for structure } \\
& A_{S S E}=\text { safe shutdown earthquake acceleration }
\end{aligned}
$$




\section{Standard Normal (Gaussian) Distribution}

- Useful function in many statistics and probability problems

- Normal distribution with mean $=0$,

$$
\text { and standard deviation }=1.0
$$

- Tables for standard normal distribution available in almost every probability and statistics text 
Standard Normal Probability Table

The table shows the cumulative probabilities (i.e., the area to the left of $z$ )

Cumulative probabilities for NEGATIVE z-values

\begin{tabular}{|l|r|r|r|r|r|r|r|r|r|r|}
\hline$z$ & 0 & 0.01 & 0.02 & 0.03 & 0.04 & 0.05 & 0.06 & 0.07 & 0.08 & 0.09 \\
\hline
\end{tabular}

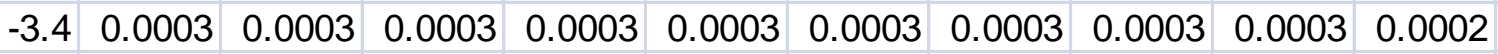
\begin{tabular}{|l|l|l|l|l|l|l|l|l|l|l|l|}
-3.3 & 0.0005 & 0.0005 & 0.0005 & 0.0004 & 0.0004 & 0.0004 & 0.0004 & 0.0004 & 0.0004 & 0.0003 \\
\hline
\end{tabular} \begin{tabular}{|l|l|l|l|l|l|l|l|l|l|l|l|}
-3.2 & 0.0007 & 0.0007 & 0.0006 & 0.0006 & 0.0006 & 0.0006 & 0.0006 & 0.0005 & 0.0005 & 0.0005 \\
\hline
\end{tabular} \begin{tabular}{|l|l|l|l|l|l|l|l|l|l|l|l|}
-3.1 & 0.001 & 0.0009 & 0.0009 & 0.0009 & 0.0008 & 0.0008 & 0.0008 & 0.0008 & 0.0007 & 0.0007 \\
\hline
\end{tabular} \begin{tabular}{|l|l|l|l|l|l|l|l|l|l|l|}
\hline-3 & 0.0013 & 0.0013 & 0.0013 & 0.0012 & 0.0012 & 0.0011 & 0.0011 & 0.0011 & 0.001 & 0.001 \\
\hline
\end{tabular} \begin{tabular}{l|l|l|l|l|l|l|l|l|l|l|l|}
-2.9 & 0.0019 & 0.0018 & 0.0018 & 0.0017 & 0.0016 & 0.0016 & 0.0015 & 0.0015 & 0.0014 & 0.0014 \\
\hline
\end{tabular} \begin{tabular}{|l|l|l|l|l|l|l|l|l|l|l|}
-2.8 & 0.0026 & 0.0025 & 0.0024 & 0.0023 & 0.0023 & 0.0022 & 0.0021 & 0.0021 & 0.002 & 0.0019 \\
\hline
\end{tabular} \begin{tabular}{|l|l|l|l|l|l|l|l|l|l|l|}
-2.7 & 0.0035 & 0.0034 & 0.0033 & 0.0032 & 0.0031 & 0.003 & 0.0029 & 0.0028 & 0.0027 & 0.0026 \\
\hline
\end{tabular} \begin{tabular}{|l|l|l|l|l|l|l|l|l|l|l|}
-2.6 & 0.0047 & 0.0045 & 0.0044 & 0.0043 & 0.0041 & 0.004 & 0.0039 & 0.0038 & 0.0037 & 0.0036 \\
\hline
\end{tabular} \begin{tabular}{l|l|l|l|l|l|l|l|l|l|l|}
-2.5 & 0.0062 & 0.006 & 0.0059 & 0.0057 & 0.0055 & 0.0054 & 0.0052 & 0.0051 & 0.0049 & 0.0048 \\
\hline
\end{tabular} \begin{tabular}{|l|l|l|l|l|l|l|l|l|l|l|}
-2.4 & 0.0082 & 0.008 & 0.0078 & 0.0075 & 0.0073 & 0.0071 & 0.0069 & 0.0068 & 0.0066 & 0.0064 \\
\hline
\end{tabular} \begin{tabular}{ll|l|l|l|l|l|l|l|l|l|l|l|}
-2.3 & 0.0107 & 0.0104 & 0.0102 & 0.0099 & 0.0096 & 0.0094 & 0.0091 & 0.0089 & 0.0087 & 0.0084 \\
\hline
\end{tabular} \begin{tabular}{|l|l|l|l|l|l|l|l|l|l|l|l|l|}
-2.2 & 0.0139 & 0.0136 & 0.0132 & 0.0129 & 0.0125 & 0.0122 & 0.0119 & 0.0116 & 0.0113 & 0.011 \\
\hline
\end{tabular} \begin{tabular}{|l|l|l|l|l|l|l|l|l|l|l|}
-2.1 & 0.0179 & 0.0174 & 0.017 & 0.0166 & 0.0162 & 0.0158 & 0.0154 & 0.015 & 0.0146 & 0.0143 \\
\hline
\end{tabular} \begin{tabular}{|l|l|l|l|l|l|l|l|l|l|l|l|}
-2 & 0.0228 & 0.0222 & 0.0217 & 0.0212 & 0.0207 & 0.0202 & 0.0197 & 0.0192 & 0.0188 & 0.0183 \\
\hline
\end{tabular} \begin{tabular}{|l|l|l|l|l|l|l|l|l|l|l|l|}
-1.9 & 0.0287 & 0.0281 & 0.0274 & 0.0268 & 0.0262 & 0.0256 & 0.025 & 0.0244 & 0.0239 & 0.0233 \\
\hline
\end{tabular} \begin{tabular}{l|l|l|l|l|l|l|l|l|l|l|}
-1.8 & 0.0359 & 0.0351 & 0.0344 & 0.0336 & 0.0329 & 0.0322 & 0.0314 & 0.0307 & 0.0301 & 0.0294 \\
\hline
\end{tabular} \begin{tabular}{l|l|l|l|l|l|l|l|l|l|l|l|l|}
-1.7 & 0.0446 & 0.0436 & 0.0427 & 0.0418 & 0.0409 & 0.0401 & 0.0392 & 0.0384 & 0.0375 & 0.0367 \\
\hline
\end{tabular} \begin{tabular}{l|l|l|l|l|l|l|l|l|l|l|l|}
-1.6 & 0.0548 & 0.0537 & 0.0526 & 0.0516 & 0.0505 & 0.0495 & 0.0485 & 0.0475 & 0.0465 & 0.0455 \\
\hline
\end{tabular} \begin{tabular}{l|l|l|l|l|l|l|l|l|l|l|}
-1.5 & 0.0668 & 0.0655 & 0.0643 & 0.063 & 0.0618 & 0.0606 & 0.0594 & 0.0582 & 0.0571 & 0.0559 \\
\hline
\end{tabular} \begin{tabular}{l|l|l|l|l|l|l|l|l|l|l|l|l|}
-1.4 & 0.0808 & 0.0793 & 0.0778 & 0.0764 & 0.0749 & 0.0735 & 0.0721 & 0.0708 & 0.0694 & 0.0681
\end{tabular} 


\section{Component Fragility Curves}

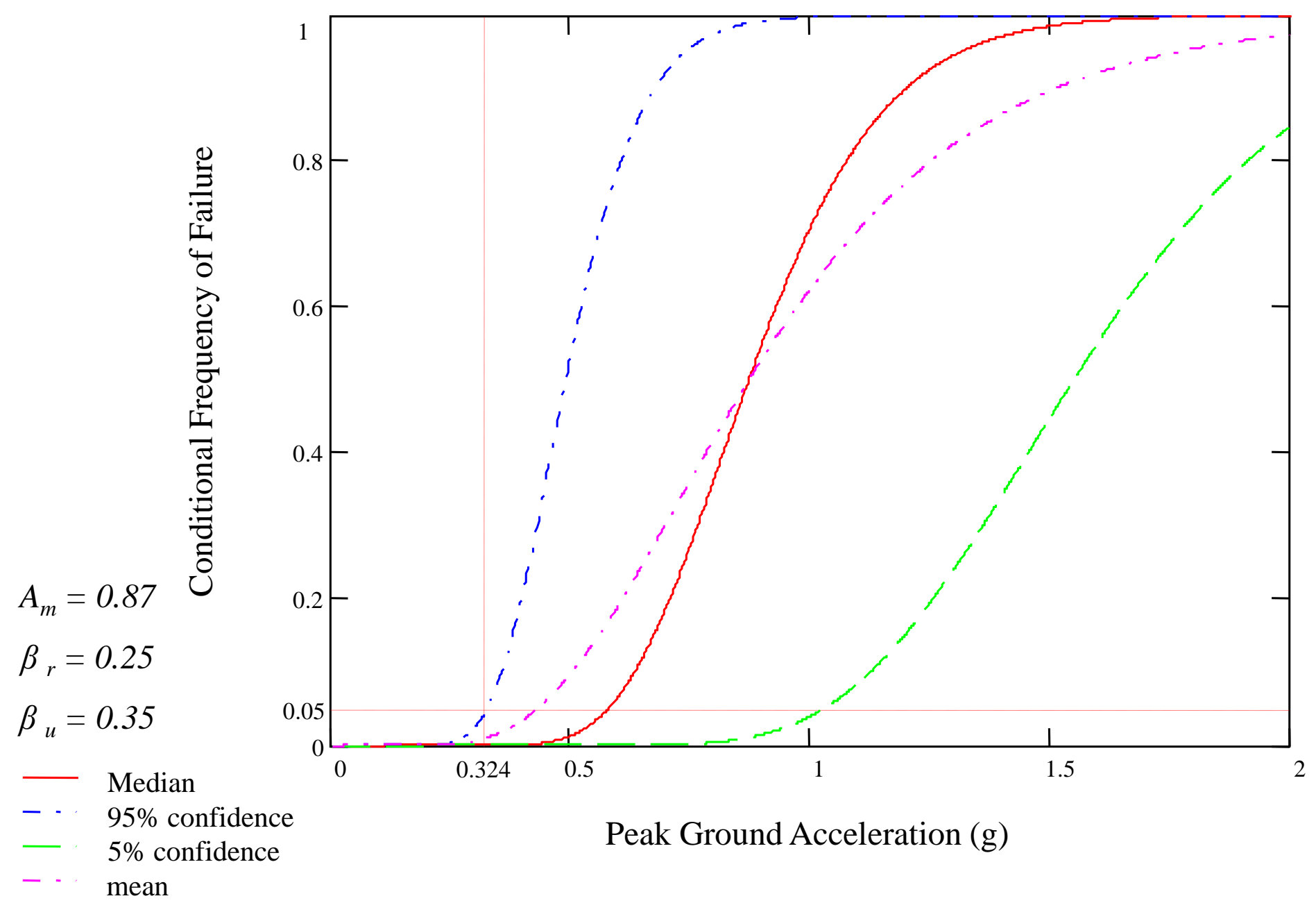




\section{Failure Probability Calculation}

- Median fragility function (curve) evaluated at a specific g-level to estimate the conditional probability of failure given an earthquake of a specific magnitude

\section{$\operatorname{Prob}($ fail $\mid \mathrm{a})=\Phi\left(\ln \left(\mathrm{a} / \mathrm{Am}_{\mathrm{m}}\right) / \beta_{\mathrm{r}}\right)$}

- Where:

$\Phi$ (phi) is the cumulative standard normal or Gaussian distribution

$a=$ earthquake magnitude

$A_{m}=$ median fragility

$\beta_{\mathrm{r}}=$ uncertainty parameter (randomness) 


\section{Failure Probability Calculation}

- Mean fragility function (curve) evaluated at a specific g-level to estimate the conditional probability of failure given an earthquake of a specific magnitude

\section{$\operatorname{Prob}($ fail $\mid \mathrm{a})=\Phi\left(\ln \left(\mathrm{a} / \mathrm{Am}_{\mathrm{m}}\right) / \beta_{\mathrm{c}}\right)$}

- Where:

$\Phi$ (phi) is the cumulative standard normal or Gaussian distribution

$a=$ earthquake magnitude

$A_{m}=$ median fragility

$\beta_{\mathrm{c}}=$ uncertainty parameter $; \operatorname{Sqrt}\left(\beta_{\mathrm{r}}{ }^{\wedge} 2+\beta_{\mathrm{u}}{ }^{\wedge} 2\right)$ 


\section{Equations Used to Generate Fragility Curves}

- $95 \%$ confidence fragility function (curve) evaluated at a specific g-level to estimate the conditional probability of failure given an earthquake of a specific magnitude

$$
\operatorname{Prob}(\text { fail } \mid \mathrm{g})=\Phi\left(\frac{\left.\ln \left[\left(\frac{\mathrm{g}}{\mathrm{Am}}\right) e^{\left(\beta u\left[\Phi^{-1}(0.95)\right]\right.}\right)\right]}{\beta_{r}}\right)
$$




\section{Terminology (Continued)}

- HCLPF (High Confidence of Low Probability of Failure)

- The earthquake acceleration level at which the analysts' have a 95\% confidence that the chance of a specific structure or component failure is less than $5 \%$, when the structure or component is subjected to an earthquake of that magnitude.

- HCLPF value should be higher than design basis earthquake if all structures and components were designed to regulatory accepted criteria. 


\section{HCLPF Calculation}

- Earthquake magnitude at which the SSC is predicted with $95 \%$ confidence to have a $5 \%$ failure probability

$$
\mathrm{HCLPF}=\left(\mathrm{Am}_{\mathrm{m}}\right) \exp \left[-1.645\left(\beta_{\mathrm{r}}+\beta_{\mathrm{u}}\right)\right]
$$

- Where:

$-A_{m}=$ median fragility

- $\beta_{\mathrm{r}}=$ randomness parameter

$-\beta_{\mathrm{u}}=$ uncertainty parameter 


\section{Fragility Methodology and Examples}

- Methodology

- EPRI TR-103959 (1994)

- EPRI TR-1002988 (2003)

- Examples

- NUREG/CR-5270 (1989)

- Conclusion was that there was more variation in analysts than in methods.

- NUREG-1150 (1990)

- Published SPRA's 


\section{Fragilities Calculated Different Ways}

- Response factor can be included in fragility or hazard (spectral acceleration)

- Need to be consistent between the two, don't over-count or undercount response factor

- Fragility stated for a SSC might not be for the SSC itself

- Building collapse or anchor failure might dominate 


\section{Components Typically Needing Capacity}

Evaluations

- Bad actor relays.

- Unreinforced or lightly reinforced masonry and block walls that may impact safety components.

- Flat bottom tanks; e.g., RWST, CST.

- Electrical cabinets.

- Large heat exchangers and vessels.

- Long column pumps.

- Most fragilities developed from existing plant documentation. 


\section{Significance of Contact Chatter}

- Could impact the availability of components required to maintain the reactor in a safe shutdown condition.

- Could cause operator confusion because of unusual equipment operating configurations as well as inconsistent and erroneous indications on control panels.

- Could induce interfacing systems LOCA.

- Could lock out containment isolation. 


\section{Relay Chatter Evaluation Steps}

- Includes electric relays, contactors, and switches prone to chatter.

- Determine types of relays installed in risk-related circuits.

- Screen out relays known to be not sensitive to high frequency vibration (High Ruggedness Relays).

- Review circuit diagrams to screen out relays whose chatter would not matter. 


\section{Relay Chatter Evaluation Steps (Continued)}

- Screen out relays if recovery actions can be reasonably assured. (HRA must consider stress from earthquake.)

- Develop fragilities for remaining relays, add to seismic event tree, and determine if they affect important scenarios.

- For relays in dominant scenarios, consider replacement or testing to show insensitivity to high frequencies. 


\section{Relay Chatter Evaluation (Continued)}

- Fragility calculations for relays should address these issues:

- Relay Capacity (GERS, Test Data, BNL Data)

- Single-Axis Sensitivity

- Cabinet Amplification

- Clipping of Demand

- State of Operation (open, closed, energized, de-energized)

- EPRI NP-7147, "Seismic Ruggedness of Relays," Volume 2: Addendum 2, April 1995. 


\section{Equations Used to Generate Fragility Curves}

- Median curve: $\operatorname{Prob}(f a i l \mid g)=\Phi\left[\ln \left(g / A_{m}\right) / \beta_{r}\right]$

- Mean curve: $\operatorname{Prob}\left(\right.$ faillg) $=\Phi\left[\ln \left(g / A_{m}\right) / \beta_{c}\right]$

$$
\beta_{\mathrm{c}}=\operatorname{sqrt}\left(\beta_{\mathrm{r}}{ }^{2}+\beta_{\mathrm{u}}{ }^{2}\right)
$$

- $95 \%$ confidence curve:

$$
\operatorname{Prob}(\text { fail } \mid \mathrm{g})=\Phi\left(\frac{\left.\ln \left[\left(\frac{\mathrm{g}}{\mathrm{Am}}\right) e^{\left(\beta u\left[\Phi^{-1}(0.95)\right]\right.}\right)\right]}{\beta_{r}}\right)
$$




\section{HCLPF Calculation}

- Earthquake magnitude at which the SSC is predicted with 95\% confidence to have a $5 \%$ failure probability

\section{$\mathrm{HCLPF}=\left(\mathrm{Am}_{\mathrm{m}}\right) \exp \left[-1.645\left(\beta_{\mathrm{r}}+\beta_{\mathrm{u}}\right)\right]$}

- Where:

$$
\begin{aligned}
& A_{m}=\text { median fragility } \\
& \beta_{r}=\text { randomness parameter } \\
& \beta_{u}=\text { uncertainty parameter }
\end{aligned}
$$




\section{Workshop on Fragility Calculations}

$$
\begin{aligned}
& A_{m}=0.87 \\
& \beta_{r}=0.25 \\
& \beta_{u}=0.35
\end{aligned}
$$

Calculate the requested failure probabilities for the given g-levels: $95 \%$ confidence for $0.5 \mathrm{~g}$

Mean for $1.0 \mathrm{~g}$

Median for $1.5 \mathrm{~g}$

Calculate HCLPF 


\section{Standard Normal Probability Table}

\begin{tabular}{|l|l|l|l|l|}
\hline$Z$ & $P R$ & $Z$ & $P R$ \\
\hline-3.4 & 0.0003 & & 3.4 & 0.9997 \\
\hline-3.3 & 0.0005 & & 3.3 & 0.9995 \\
\hline-3.2 & 0.0007 & & 3.2 & 0.9993 \\
\hline-3.1 & 0.001 & & 3.1 & 0.999 \\
\hline-3 & 0.0013 & & 3 & 0.9987 \\
\hline-2.9 & 0.0019 & & 2.9 & 0.9981 \\
\hline-2.8 & 0.0026 & & 2.8 & 0.9974 \\
\hline-2.7 & 0.0035 & & 2.7 & 0.9965 \\
\hline-2.6 & 0.0047 & & 2.6 & 0.9953 \\
\hline-2.5 & 0.0062 & & 2.5 & 0.9938 \\
\hline-2.4 & 0.0082 & & 2.4 & 0.9918 \\
\hline-2.3 & 0.0107 & & 2.3 & 0.9893 \\
\hline-2.2 & 0.0139 & & 2.2 & 0.9861 \\
\hline-2.1 & 0.0179 & & 2.1 & 0.9821 \\
\hline-2 & 0.0228 & & 2 & 0.9772 \\
\hline-1.9 & 0.0287 & & 1.9 & 0.9713 \\
\hline-1.8 & 0.0359 & & 1.8 & 0.9641 \\
\hline-1.7 & 0.0446 & & 1.7 & 0.9554 \\
\hline-1.6 & 0.0548 & & 1.6 & 0.9452 \\
\hline-1.5 & 0.0668 & & 1.5 & 0.9332 \\
\hline-1.4 & 0.0808 & & 1.4 & 0.9192 \\
\hline-1.3 & 0.0968 & & 1.3 & 0.9032 \\
\hline-1.2 & 0.1151 & & 1.2 & 0.8849 \\
\hline-1.1 & 0.1357 & & 1.1 & 0.8643 \\
\hline-1 & 0.1587 & & 1 & 0.8413 \\
\hline-0.9 & 0.1841 & & 0.9 & 0.8159 \\
\hline-0.8 & 0.2119 & & 0.8 & 0.7881 \\
\hline-0.7 & 0.242 & & 0.7 & 0.758 \\
\hline-0.6 & 0.2743 & & 0.6 & 0.7257 \\
\hline-0.5 & 0.3085 & & 0.5 & 0.6915 \\
\hline-0.4 & 0.3446 & & 0.4 & 0.6554 \\
\hline-0.3 & 0.3821 & & 0.3 & 0.6179 \\
\hline-0.2 & 0.4207 & & 0.2 & 0.5793 \\
\hline-0.1 & 0.4602 & & 0.1 & 0.5398 \\
\hline 0 & 0.5 & & 0 & 0.5 \\
\hline & & & & \\
\hline & & & \\
\hline & & & \\
\hline
\end{tabular}




\section{Workshop on Fragility Calculations}




\section{Workshop on Fragility Calculations}

$$
\begin{aligned}
& A_{m}=0.87 \mathrm{~g} \\
& \beta_{r}=0.25 \\
& \beta_{u}=0.35 \\
& \beta_{c}=\left(.25^{\wedge} 2+.35^{\wedge} 2\right)^{\wedge} .5=.43
\end{aligned}
$$

Median curve: $\operatorname{Prob}(f a i l \mid g)=\Phi\left[\ln \left(g / A_{m}\right) / \beta_{r}\right]=\Phi[\ln (1.5 / .87) / .25]=\Phi[2.178]$

$$
\text { Prob }(\text { fail } \mid 1.5 \mathrm{~g})=0.985
$$

Mean curve: $\operatorname{Prob}($ fail $\mid g)=\Phi\left[\ln \left(g / A_{m}\right) / \beta_{c}\right]=\Phi[0.324]$

$$
\text { Prob(fail } \mid 1 \mathrm{~g})=0.627
$$

$95 \%$ confidence for $0.5 \mathrm{~g}=\Phi[0.0872]=0.535$

$\mathrm{HCLF}=0.324 \mathrm{~g}$ 


\section{Seismic Analysis Methods}




\section{Seismic Analysis Methods Overview}

- Three Levels of Earthquakes

- Operating Basis Earthquake (OBE)

- Operating basis earthquake ground motion $(O B E)$ is the vibratory ground motion for which those features of the nuclear power plant necessary for continued operation without undue risk to the health and safety of the public will remain functional. The operating basis earthquake ground motion is only associated with plant shutdown and inspection unless specifically selected by the applicant as a design input.

- Design Basis Earthquake (DBE) Seismic PRA [same as SSE]

- The earthquake which the structure is required to safely withstand with repairable damage. Those systems and components important to safety must remain functional and/or operable. For design purposes, the intended use of this earthquake loading is for economic design of structures or components whose damage or failure would not lead to catastrophic loss. Also, known as Safe-shutdown earthquake ground motion (SSE)

- Review Level Earthquake (RLE)

- Ground motion for which HCLPF capacities of the SSCs are evaluated [NUREG-1407]

- Normally, define as 1.67 * DBE; Used in SMA 


\section{Seismic Analysis Methods Overview}

- Two approaches:

- Seismic Margins Analysis (SMA)

- Postulate an earthquake of a specific magnitude, then judge effect on the plant

- AKA Review Level Earthquake

- Seismic PRA

- Assess earthquake hazard (freq vs. magnitude), evaluate strength of plant SSCs (fragility), then combine the two to calculate risk 


\section{Seismic Evaluations Options for IPEEE}

- Seismic Margins Analysis

- U.S. Nuclear Regulatory Commission/LLNL Approach (failure scenarios) [NUREG/CR- 4334, 4482, not used]

- Electric Power Research Institute Approach (safe shutdown path)

- Probabilistic Risk Assessment (Level 1 plus containment performance analysis, LERF, containment isolation, etc.)

- Any other systematic examination if reviewed and found acceptable by the staff. 


\section{Seismic Margins Method}

- Different scope levels depending on plant location

- i.e., based on estimated seismic hazard

- NUREG-1407 provides a list including specification of the review level earthquake (RLE)

- $0.3 \mathrm{~g}$ or $0.5 \mathrm{~g}$

- Reduced Scope (uses Safe Shutdown Earthquake as RLE)

- $0.3 \mathrm{~g}$ Focused Scope

- $0.3 \mathrm{~g}$ Full Scope

- $0.5 \mathrm{~g}$ (required for Western U.S. plants)

- Diablo Canyon and San Onofre - Seismic PRA Required 


\section{NRC Seismic Margins Method}

- Vital plant functions examined (e.g., reactor sub-criticality and early core cooling)

- Screening using generic seismic capacities

- Walkdown to ensure no weaknesses exist

- Event/fault trees used to delineate accident sequences

- Typically assume transients and small LOCA 


\section{EPRI Seismic Margins Method}

- Guidance provided in EPRI NP-6041, supplemented by NUREG-1407

- Success paths identified

- For safe shutdown, given seismically induced transient or small LOCA

- Preferred path and alternate path 


\section{Steps in a Seismic PRA}

- Seismic hazard analysis - frequency vs. magnitude of ground motion

- Response spectra analysis - translates ground motion into local (ground, floor, or component) motion

- Plant walkdown - identifies typical and atypical SSCs

- Fragility analysis - assesses the "strength" of SSCs

- Systems analysis - generates seismic core damage cutsets

- Containment response and offsite consequences 
Major Differences between Seismic Margins and SPRA Options

- Seismic hazard and uncertainties (probabilistic) versus review level earthquake (deterministic).

- Accident scenarios versus limited success/failure paths.

- Risk quantification versus pass/fail.

- Quantitative ranking of component significance versus no indication of relative importance to risk. 


\section{Seismic Margin Approach}




\section{Learning Objectives}

- After studying this section, you should be able to:

- Understand seismic screening techniques

- Understand how a plant HCLPF is computed in a seismic margin assessment

- Describe key differences between the EPRI and NRC seismic margin methods 


\section{Two SMA Methodologies}

- NRC and EPRI methods

- Utilize Review Level Earthquake (RLE)

- $0.3 \mathrm{~g}$ and $0.5 \mathrm{~g}$ Peak Ground Acceleration (PGA)

- RLE for each plant assigned by NRC in IPEEE guidance (NUREG1407)

- Three scope levels

- Reduced scope, focused scope, and full scope

- Scope level for each plant assigned by NRC in IPEEE guidance (NUREG-1407) 


\section{Two SMA Methods Differ}

- NRC Methodology (NUREG/CR-4334, NUREG/CR-4482)

- Fault Tree Approach

- Abbreviated PRA

- EPRI Methodology (EPRI NP-6041, EPRI NP-6041SL)

- Success Path Approach

- Screening method

- Bases for Methodologies

- System analysis experience from prior PRAs.

- Fragility information from earthquake experience data, test data, and prior PRAs. 


\section{EPRI SMA Method}

- Success path approach

- Two success paths must be identified

- One must address small LOCA

- Each success path capable of bringing plant to a safe state (hot or cold shutdown) after an EQ larger than DBE, and maintain it for 72 hours

- Set of SSCs for each success path become focus of analysis

- Seismic capacity of each SSC in each path is evaluated

- Seismic capacity of success path is that of the weakest SSC

- Seismic capacity of plant is that of the strongest success path 


\section{IPEEE Specified Four Enhancements to EPRI SMA}

- Initial screening needs to start with more than just two success paths

- Exclusion of some paths might mask HCLPF and defense-in-depth insights

- Non-seismic failure and human actions need to be included in success path analyses

- Containment performance needs to be address

- Both containment structure and containment systems

- Relay chatter needs to be considered 


\section{EPRI SMA Comprises 7 Steps}

1. Selection of the seismic margin earthquake - specified

2. Selection of assessment team

3. Preparatory work prior to walkdown

4. Systems and elements selection ("success path") walkdown

5. Seismic capability walkdown

6. Seismic margin assessment

7. Documentation 


\section{Selection of SME}

- NRC has specified the SME (also referred to as RLE) for every plant in the U.S.

- Tables 3.1 (CEUS) and 3.2 (WUS) of NUREG-1407

- Reduced Scope plants could use the SSE ground response spectra from FSAR (i.e., design basis)

- Other plants use the response spectra from NUREG/CR-0098 anchored at $0.3 \mathrm{~g}$ or $0.5 \mathrm{~g} \mathrm{PGA}$

CEUS - Central and Eastern U.S. (east of Rocky Mountains) WUS - Western U.S. (west of Rocky Mountains) 


\section{Selection of Success Paths}

- Identify reasonably complete set of paths considering transients and small LOCAs.

- Select preferred path for transient and SBLOCA case.

- Alternate path (should involve operational sequences, systems, piping runs, and components different from preferred path).

- Nonseismic failures and human actions in selected paths show low failure probabilities $(<.01)$.

- Include containment performance in SMA (isolation, cooling, bypass). 


\section{Example Success Path Logic Diagram - PWR, Intact Reactor Coolant System Pressure Boundary}

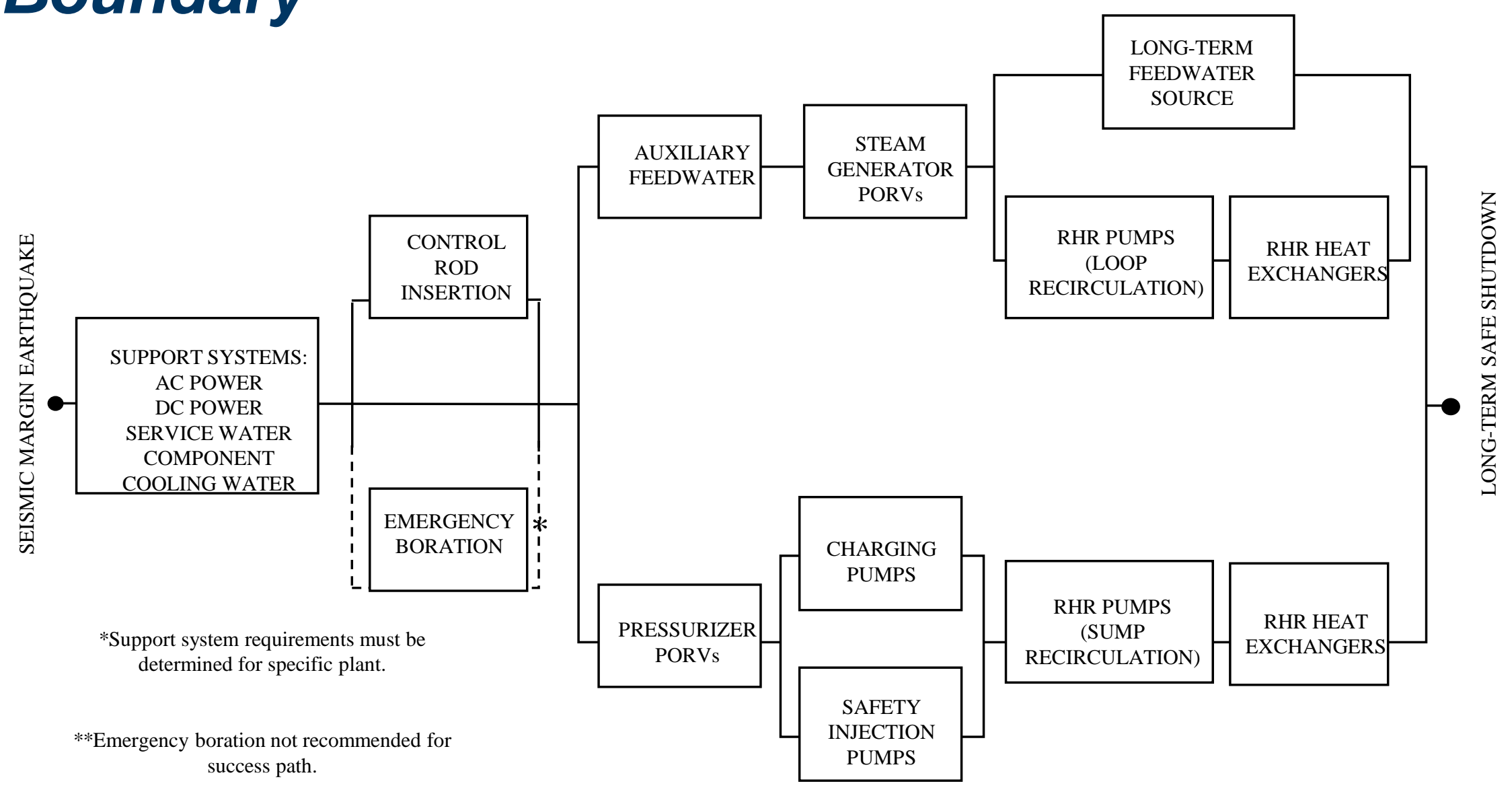




\section{BWR/6 Example Success Path}

\begin{tabular}{|l|l|}
\hline Safety Function & Required System \\
\hline All & Support Systems \\
\hline Reactivity Control & Reactor Protection System \\
\hline Pressure Control & Main Steam Isolation \\
\cline { 2 - 2 } & Safety Relief Valves \\
\hline $\begin{array}{l}\text { Core Cooling and Inventory } \\
\text { Control }\end{array}$ & High Pressure Injection \\
\hline Decay Heat Removal & Residual Heat Removal \\
\hline
\end{tabular}




\section{Two Walkdowns Are Performed}

- Initial Screening Walkdown

- Objective is to identify those success paths that are easiest to demonstrate a high seismic margin

- Seismically weak SSCs are screened-out

- Identify any evaluation problems

- Missing anchorages or spatial interactions

- Seismic Capacity Walkdown

- Identify those SSCs in the success path whose seismic margin (w.r.t. the RLE) is in question

- Seismically strong SSCs are screened-out

- Develop list of SSCs that require more detailed assessment 


\section{Success Path HCLPF}

- HCLPF - g-level at which there is a High Confidence (95\%) of Low Probability (5\%) of Failure

- Lowest HCLPF in a success path is the HCLPF for that success path

- Highest HCLPF of the two success paths is the plant HCLPF 


\section{EPRI SMA Summary}

- EPRI Seismic Margins

- Similar to SQUG program for A-46

- Deterministic (but includes some probabilistic aspects)

- Safe shutdown paths and associated equipment

- Use of EQ experience and judgment for screening

- Walkdowns (vital part of approach) and screening

- Selected calculations

- HCLPF defined for weak link in shutdown paths 


\section{NRC SMA Summary}

- NRC Seismic Margins

- Similar to PRA without use of seismic hazard

- Plant systems models and seismic fragility curves

- Use of PRA and EQ experience for screening

- Walkdown and screening

- Dominant accident sequences and plant level HCLPF derived from fragility curves and systems models

- Core damage frequency not computed (since no IE/hazard frequency) 


\section{Plant System and Sequence Analysis}




\section{External Event Analysis Approach}

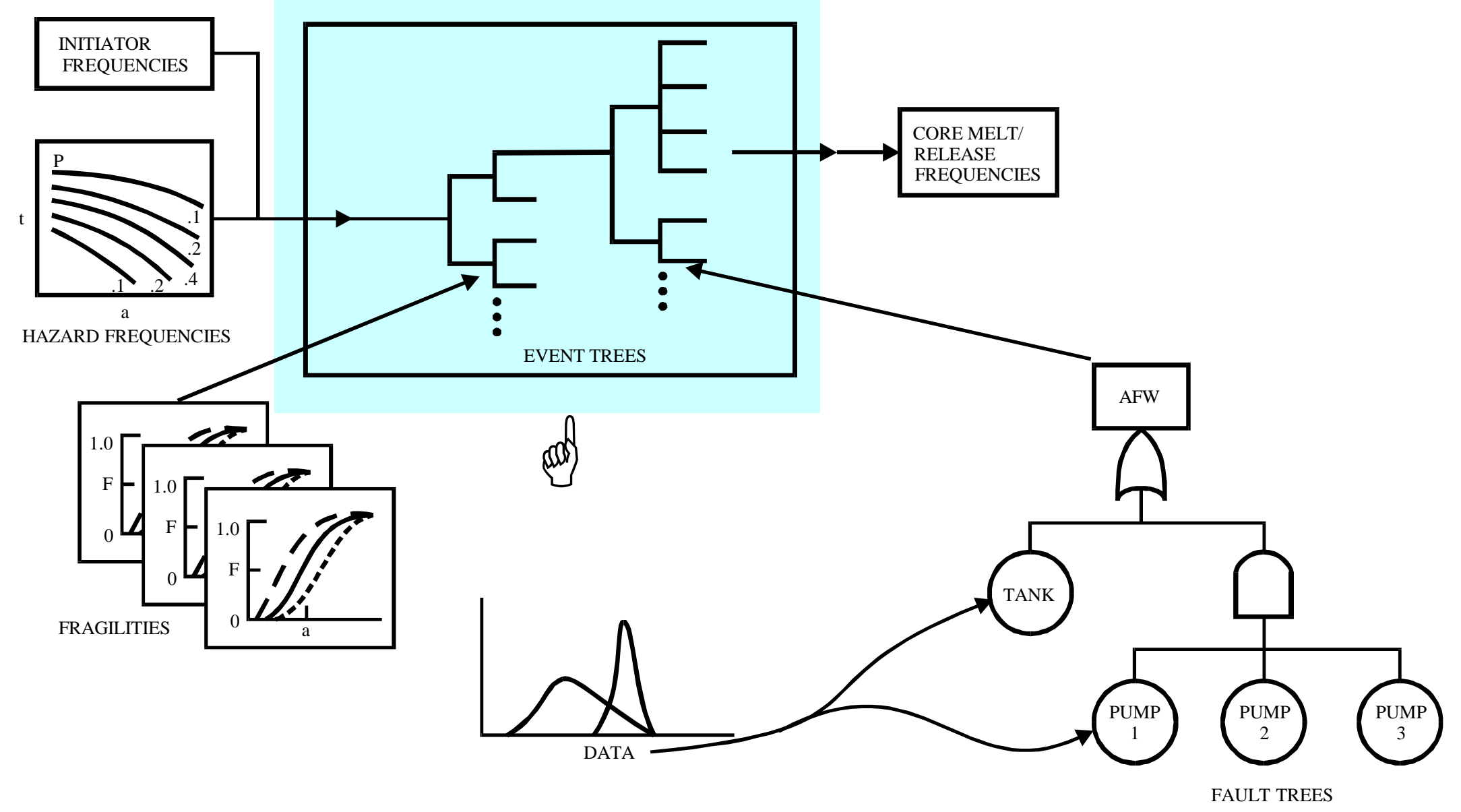




\section{Learning Objectives}

- After studying this section, you should be able:

- To explain how seismic-induced failures can be incorporated into an accident sequence model.

- List key issues related to seismic-initiated event sequence modeling. 


\section{Plant System and Sequence Analysis}

- Identify earthquake-induced initiating events.

- Account for increased likelihood of multiple safety system failures.

- Account for correlation and increased dependencies between component failures.

- Combine random and seismic-induced failures.

- Two general approaches: fault tree linking and event tree with boundary conditions. 


\section{Identify Initiators}

- Use component fragilities to rank components, including structural failures.

- Review applicability of nonseismic initiators.

- Initiator frequencies obtained by multiplying hazard frequencies at different earthquake acceleration levels with component fragilities.

- Multiple initiators may have significant frequency. 


\section{Earthquake Sequence Modeling}

- Fault Tree Linking Approach

- Adapt nonseismic event trees to account for earthquake-induced initiators and consequential failures.

- Revise modeling approximations made for internal events if failure frequencies have significantly changed.

- System fault trees are modified to include basic events attributed to earthquake-induced failure modes.

- Alternate Fault Tree Linking Approach

- A core damage fault tree may be developed for all earthquake sequences.

- Quantification of minimal cutsets must not employ the rare-event approximation. 


\section{Oconee Seismic Analysis}

- Seismic event tree used to develop sequence logic

- Sequence logic quantified using single fault trees

- Support Systems

- Relay Chatter 


\section{Seismic Event Tree}




\section{Seismic Sequence Fault Tree Logic}

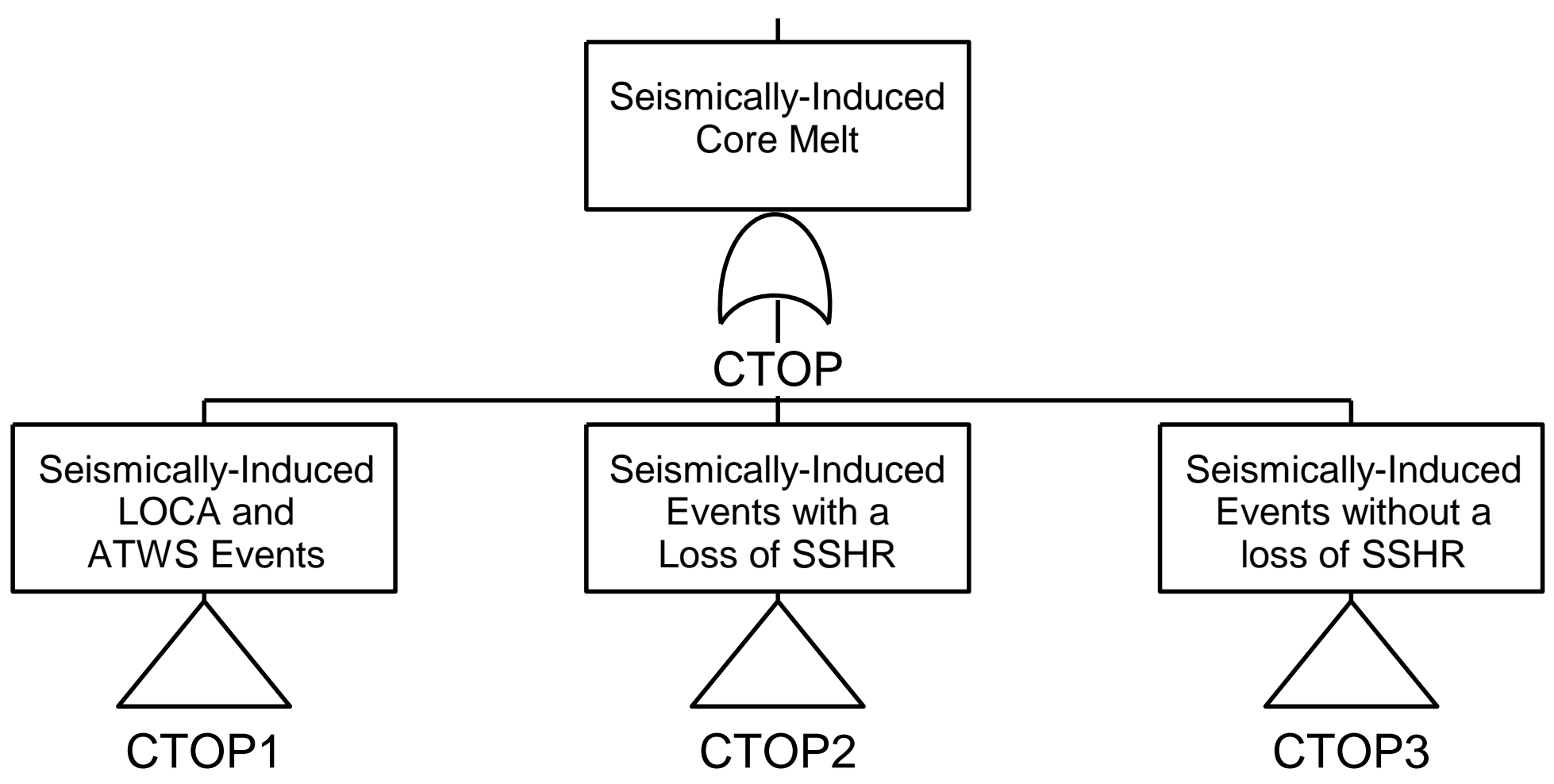




\section{Seismic Sequence Fault Tree Logic (Continued)}

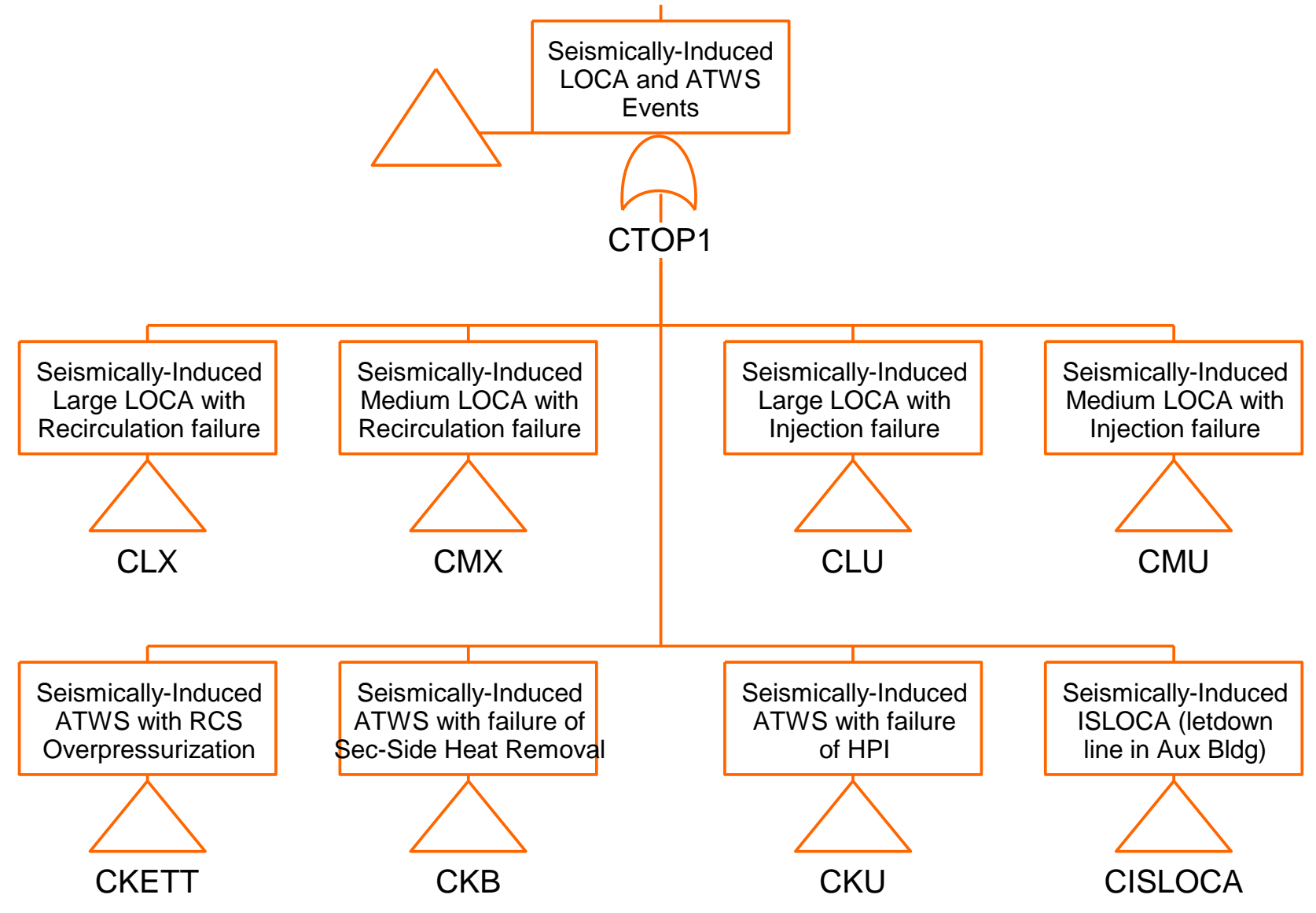




\section{Seismic Sequence Fault Tree Logic (Continued)}

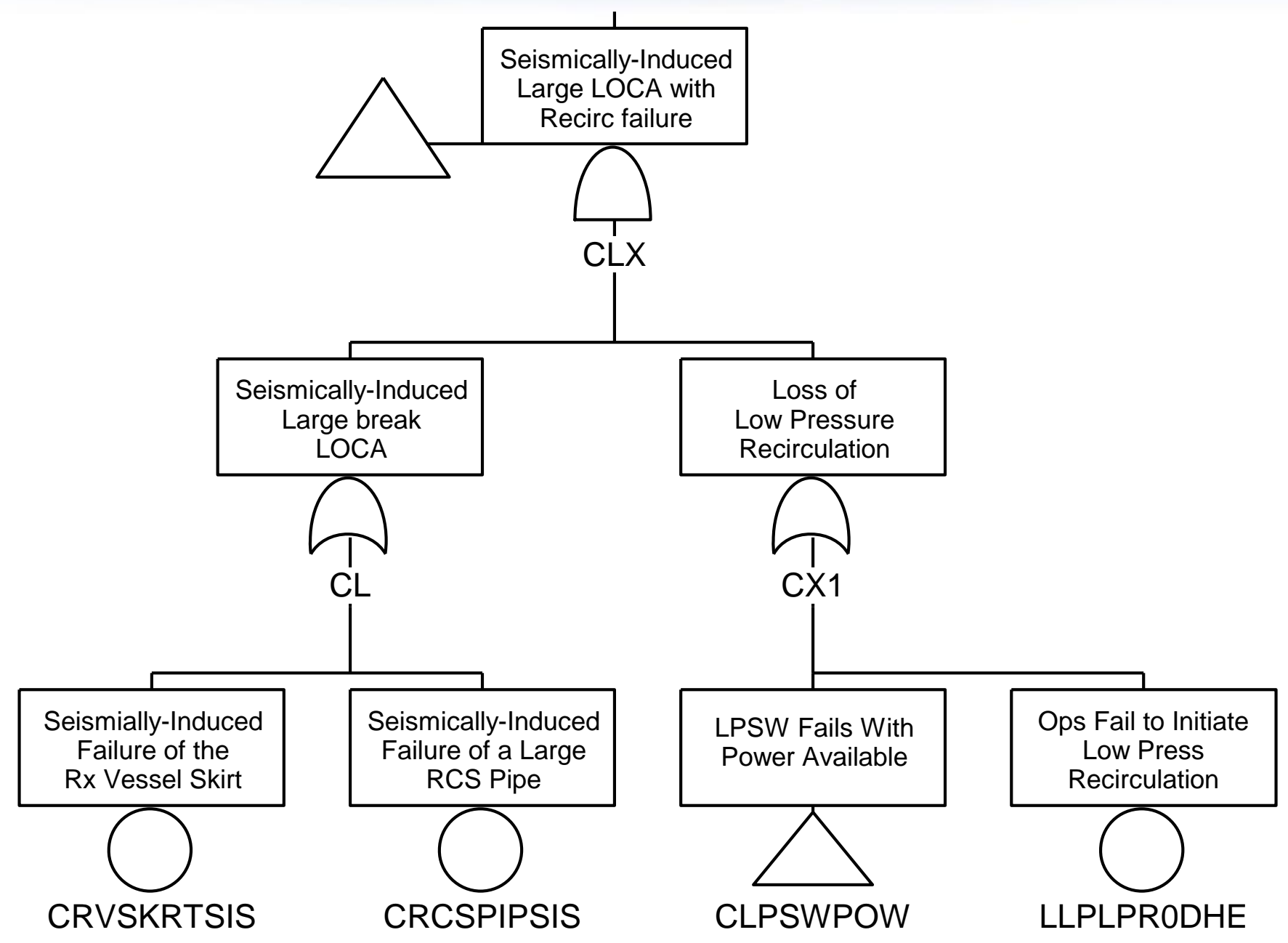




\section{Seismic Sequence Fault Tree Logic (Continued)}

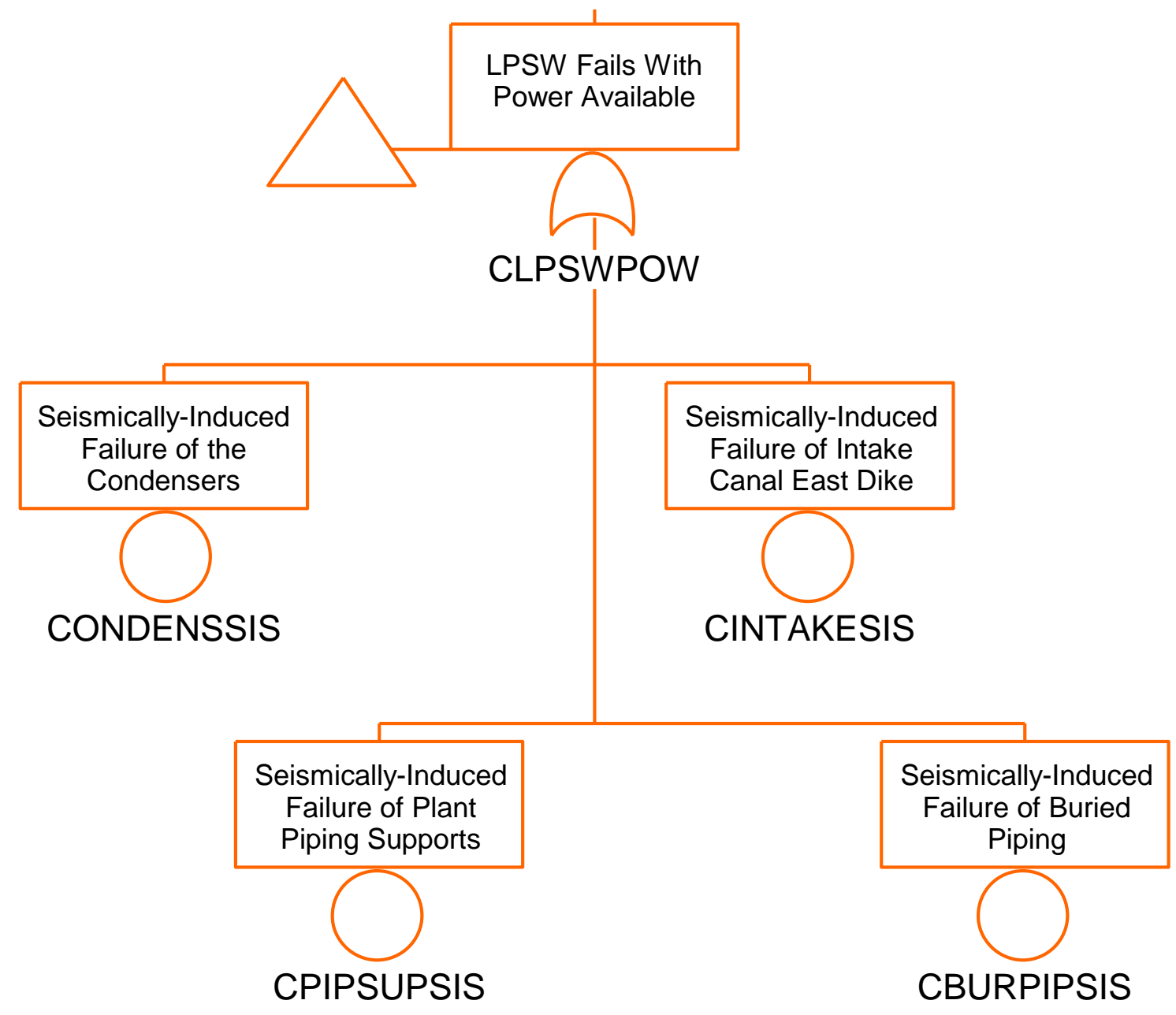




\section{Earthquake Sequence Modeling Event Tree Linking Approach}

- Earthquakes for different ranges of acceleration are defined as initiators.

- All seismic failures represented by a new single seismic event tree.

- Group components into seismic failure top events.

- Use same support event trees as for internal events.

- Use same general transient or other frontline event trees, depending on seismic failure initiator. 


\section{Earthquake Sequence Modeling Event Tree Linking Approach}

- Define new top events on existing trees for seismic unique impacts; e.g., relay chatter and excessive LOCAs.

- Account for dependencies between earthquake failures and system responses.

- Quantify event trees for each range of earthquakes.

- Plant damage state assignment similar to non-seismic. 


\section{Example - Seismic Initiating Events}

\begin{tabular}{||l|c|c||}
\hline $\begin{array}{c}\text { SEISMIC } \\
\text { INITIATING } \\
\text { EVENT } \\
\text { DESIGNATOR }\end{array}$ & $\begin{array}{c}\text { SPECTRAL* } \\
\text { ACCELERATION } \\
\text { LEVEL (g) }\end{array}$ & $\begin{array}{c}\text { FREQUENCY } \\
\text { (PER YEAR) }\end{array}$ \\
\hline \hline SEIS1 & 0.0 to 1.25 & $1.41 E-02$ \\
\hline SEIS2 & 1.25 to 1.75 & $8.00 E-04$ \\
\hline SEIS3 & 1.75 to 2.0 & $1.47 E-04$ \\
\hline SEIS4 & 2.0 to 2.5 & $1.17 E-04$ \\
\hline SEIS5 & 2.5 to 3.0 & $2.82 E-05$ \\
\hline SEIS6 & 3.0 to 4.0 & $7.43 E-06$ \\
\hline TOTAL SEISMIC INITIATING EVENT & $1.52 E-02$ \\
FREQUENCY
\end{tabular}

* Average $5 \%$ damped spectral acceleration over the $3-8.5 \mathrm{~Hz}$ frequency range 


\section{Seismic PRA Component Groupings for Top Events}

\begin{tabular}{||l|l||}
\hline \multicolumn{1}{|c|}{ Seismic TOP Event } & \multicolumn{1}{|c|}{ Components/Structures } \\
\hline SOP - OFFSITE POWER & OFFSITE POWER, 230 KV \\
\hline SDC - 125V DC POWER & $\begin{array}{l}\text { AUXILLARY BUILDING } \\
\text { BATTERIES } \\
\text { DC SWTCHGEAR/BREAKER PANEL }\end{array}$ \\
\hline STRUT - TURBINE BUILDING STRUT & STRUT FOR TURBINE BUILDING \\
\hline SACSS - ALL 4KV VITAL AC POWER/STRUT \\
SUCCESS & $\begin{array}{l}\text { TURBINE BUILDING SHEAR WALL } \\
\text { AKV SWITCHGEAR } \\
\text { SAFEGUARD RELAY PANEL } \\
\text { BATTERY CHARGERS } \\
\text { 4KV/48OV TRANSFORMERS } \\
\text { BUS F POTENTIAL TRANSFORM } \\
\text { BLOCK WALLS }\end{array}$ \\
\hline SACSF - ALL 4KV VITAL AC POWER/STRUT & $\begin{array}{l}\text { SUALURE } \\
\text { FALBINE BUILDING SHEAR WALL } \\
\text { BATTERY CHARGERS } \\
\text { AKV/48OV TRANSFORMERS } \\
\text { SWITCHGEAR/STRUT FAILURE } \\
\text { SAFEGUARD RELAY PANEL/STR } \\
\text { BUS F POTENTIAL TRANSFORM } \\
\text { BLOCK WALLS }\end{array}$ \\
\hline
\end{tabular}




\section{Seismic PRA Component Groupings for Top Events (Continued)}

\begin{tabular}{|c|c|}
\hline Seismic Top Event & Components/Structures \\
\hline SDG - ALL SIX DIESEL GENERATORS & $\begin{array}{l}\text { DIESEL GENERATORS } \\
\text { DG RADIATOR/WATER PUMPS } \\
\text { DG EXCITATION CUBICAL } \\
\text { DG CONTROL PANEL }\end{array}$ \\
\hline SFO - FUEL OIL TRANSFER & $\begin{array}{l}\text { DG FUEL OIL PUMPS/FILTERS } \\
\text { BOP PIPING AND SUPPORTS }\end{array}$ \\
\hline SVI - ALL FOUR VITAL INSTRUMENT CHANNELS & $\begin{array}{l}\text { INVERTERS } \\
\text { PROCESS CONTROL AND PROTECTION } \\
\text { PRESSURE AND DP TRANSMITTERS }\end{array}$ \\
\hline SRT - REACTOR TAIP & REACTOR INTERNALS \\
\hline SPT - PARTIAL REACTOR TRIP & REACTOR TRIP SWITCHGEAR \\
\hline SCV - CONTROL ROOM VENTILATION & $\begin{array}{l}\text { CONTROL ROOM SUPPLY FANS } \\
\text { HVAC DUCTING AND SUPPOATS }\end{array}$ \\
\hline SCC - COMPONENT COOLING WATER & $\begin{array}{l}\text { RHA HEAT EXCHANGERS } \\
\text { CCW PUMPS } \\
\text { CCW HEAT EXCHANGERS } \\
\text { CCW SURGE TANK } \\
\text { BOP PIPING AND SUPPORTS }\end{array}$ \\
\hline
\end{tabular}




\section{Seismic and Non-Seismic Event Tree Calculation}

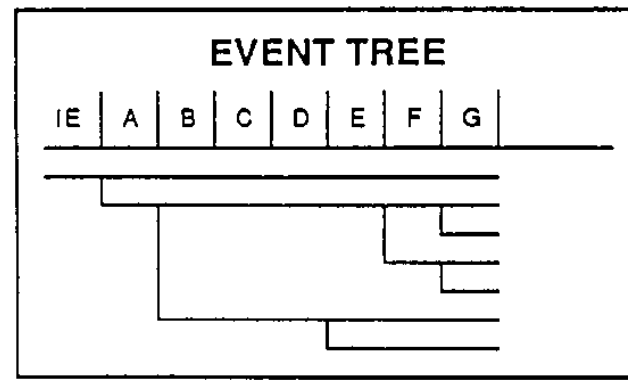

SEISMIC PRE TREE

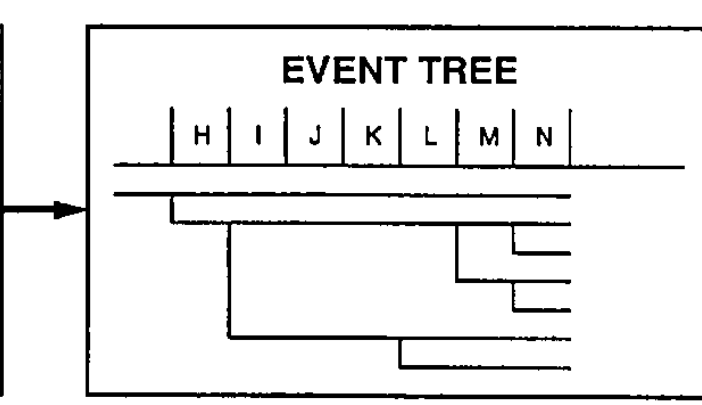

SUPPORT SYSTEM TREE

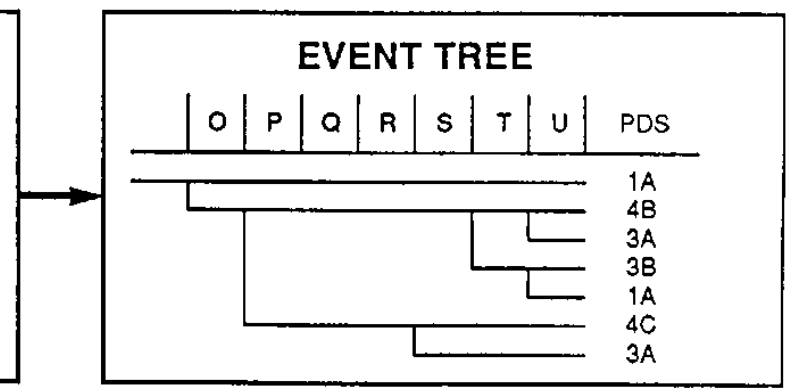

FRONTLINE SYSTEM TREE 


\section{Containment Response}

- Sequences binned into plant damage states.

- Seismic-induced containment failure modes different from IPE.

- Mechanisms leading to containment bypass; e.g., steam generator failure.

- Structural failure of the containment.

- Containment safeguards - failure of containment fan coolers creating path to CCW system outside containment.

- Containment isolation valves/signals.

- Review Level 2 containment event tree to determine if applicable to seismic core damage sequence types. 


\section{Seismic Human Action Considerations}

- Applicability of procedures.

- Error probabilities may increase with earthquake size.

- Offsite power recovery changes for earthquakes.

- Pathways to critical areas.

- Competing requirements for actions. 


\section{Approximate Relationships between Intensity and Acceleration (1 of 2)}

\begin{tabular}{|l|l|l|l|}
\hline $\begin{array}{l}\text { Modified } \\
\text { Intensity } \\
\text { Scale }\end{array}$ & $\begin{array}{l}\text { Richter } \\
\text { Mag. }\end{array}$ & $\begin{array}{l}\text { Max. } \\
\text { Accel. } \\
\text { (g) }\end{array}$ & Description of Effects \\
\hline III & 3 & $\begin{array}{l}0.003 \text { to } \\
0.007\end{array}$ & $\begin{array}{l}\text { Felt indoors. Hanging objects swing. Vibration like passing of light trucks. Duration } \\
\text { estimated. May not be recognized as an earthquake. }\end{array}$ \\
\hline IV & 4 & $\begin{array}{l}0.007 \text { to } \\
0.015\end{array}$ & $\begin{array}{l}\text { Hanging objects swing. Vibration like passing of heavy trucks; or sensation of a jolt like } \\
\text { a ball striking the walls. Standing motor cars rock. Windows, dishes, doors rattle. } \\
\text { Glasses clink. Crockery clashes. In the upper range of IV wooden walls and frames } \\
\text { creak. }\end{array}$ \\
\hline V & 4 & $\begin{array}{l}0.015 \text { to } \\
0.03\end{array}$ & $\begin{array}{l}\text { Felt outdoors; direction estimated. Sleepers wakened. Liquids disturbed, some spilled. } \\
\text { Small unstable objects displaced or upset. Doors swing, close, open. Shutters, } \\
\text { pictures move. Pendulum clocks stop, start, change rate. }\end{array}$ \\
\hline VI & 5 & $\begin{array}{l}0.03 \text { to } \\
0.09\end{array}$ & $\begin{array}{l}\text { Felt by all. Many frightened and run outdoors. Persons walk unsteadily. Windows, } \\
\text { dishes, glassware broken, knickknacks, books, etc., off shelves. Pictures off walls. } \\
\text { Furniture moved or overturned. Weak plaster and some masonry cracked. Small bells } \\
\text { ring (church, school). Trees, bushes shaken (visible, or heard to rustle). }\end{array}$ \\
\hline VII & $5-6$ & $\begin{array}{l}0.07 \text { to } \\
0.22\end{array}$ & $\begin{array}{l}\text { Difficult to stand. Noticed by drivers of motor cars. Hanging objects quiver. Furniture } \\
\text { broken. Damage to some masonry, including cracks. Weak chimneys broken at roof } \\
\text { line. Fall of plaster, loose bricks, stones, tiles, cornices (also unbraced parapets and } \\
\text { architectural ornaments). Waves on ponds; water turbid with mud. Small slides and } \\
\text { caving in along sand or gravel banks. Large bells ring. Concrete irrigation ditches } \\
\text { damaged. }\end{array}$ \\
\hline
\end{tabular}




\section{Approximate Relationships between Intensity and Acceleration (2 of 2)}

\begin{tabular}{|c|c|c|c|}
\hline $\begin{array}{l}\text { Modified } \\
\text { Mercalli } \\
\text { Intensity } \\
\text { Scale }\end{array}$ & $\begin{array}{l}\text { Richter } \\
\text { Mag. }\end{array}$ & $\begin{array}{l}\text { Max. } \\
\text { Accel. } \\
\text { (g) }\end{array}$ & Description of Effects \\
\hline VIII & 6 & $\begin{array}{l}0.15 \\
\text { to } 0.3\end{array}$ & $\begin{array}{l}\text { Steering of motor cars affected. Damage to some masonry; partial collapse. Fall of } \\
\text { stucco and some masonry walls. Twisting, fall of chimneys, factory stacks, monuments, } \\
\text { towers, elevated tanks. Frame houses moved on foundations if not bolted down; loose } \\
\text { panel walls thrown out. Decayed piling broken off. Branches broken from trees. } \\
\text { Changes in flow or temperature of springs and wells. Cracks in wet ground and on steep } \\
\text { slopes. }\end{array}$ \\
\hline IX & 7 & $\begin{array}{l}0.3 \text { to } \\
0.7\end{array}$ & $\begin{array}{l}\text { General panic. Some masonry destroyed; other masonry seriously damaged. (General } \\
\text { damage to foundations.) Frame structures, if not bolted, shifted off foundations. Frames } \\
\text { racked. Serious damage to reservoirs. Underground pipes broken. Conspicuous cracks } \\
\text { in ground. In alluviated areas sand and mud ejected, earthquake fountains, sand craters. }\end{array}$ \\
\hline $\mathrm{X}$ & $7-8$ & $\begin{array}{l}0.45 \\
\text { to } 1.5\end{array}$ & $\begin{array}{l}\text { Most masonry and frame structures destroyed with their foundations. Some well-built } \\
\text { wooden structures and bridges destroyed. Serious damage to dams, dikes, } \\
\text { embankments. Large landslides. Water thrown on banks to canals, rivers, lakes, etc. } \\
\text { Sand and mud shifted horizontally on beaches and flat land. Rails bent slightly. }\end{array}$ \\
\hline $\mathrm{XI}$ & $8+$ & $\begin{array}{l}0.5 \text { to } \\
3\end{array}$ & Rails bent greatly. Underground pipelines completely out of service. \\
\hline $\mathrm{XII}$ & $8+$ & $\begin{array}{l}0.5 \text { to } \\
7\end{array}$ & $\begin{array}{l}\text { Damage nearly total. Large rock masses displaced. Lines of sight and level distorted. } \\
\text { Objects thrown into the air. }\end{array}$ \\
\hline
\end{tabular}




\section{Key Seismic Human Actions Modeled}

- Offsite power recovery.

- Recovery from relay chatter-induced blackout.

- Align fire water cooling to charging pumps.

- Crosstie service water between units. 


\section{IPEEE Seismic Human Action : Method 1}

\begin{tabular}{|c|c|c|c|c|c|}
\hline \multirow{2}{*}{$\begin{array}{l}\text { Human } \\
\text { Action } \\
\text { Identifier }\end{array}$} & \multirow[b]{2}{*}{ Human Action Description } & \multirow{2}{*}{$\begin{array}{l}\text { Point Estimate } \\
\text { Values Used for } \\
\text { Internal Events } \\
\text { Analysis }\end{array}$} & \multicolumn{3}{|c|}{$\begin{array}{l}\text { Multiplication Factors Used } \\
\text { for Seismic Initiating Events }\end{array}$} \\
\hline & & & $\begin{array}{l}\text { SEIS1 } \\
\text { SEIS2 }\end{array}$ & $\begin{array}{l}\text { SEIS3 } \\
\text { SEIS4 } \\
\end{array}$ & $\begin{array}{l}\text { SEIS5 } \\
\text { SEIS6 }\end{array}$ \\
\hline ZHEAC1 & $\begin{array}{l}\text { Failure to Recover from } \\
\text { common cause Startup } \\
\text { Breaker Failure on Demand }\end{array}$ & 2.30E-03 & 30 & 30 & 30 \\
\hline ZHEAS1 & $\begin{array}{l}\text { Failure to remotely crosstie } \\
\text { U1 \& U2 ASW-Both U1 } \\
\text { Pumps Failure }\end{array}$ & $7.10 E-03$ & 30 & 30 & 30 \\
\hline ZHEAS2 & $\begin{array}{l}\text { Failure to Locally crosstie } \\
\text { U1 \& U2 ASW or Fail to } \\
\text { Open }\end{array}$ & $5.90 E-03$ & 1 & 5 & 30 \\
\hline ZHECC1 & $\begin{array}{l}\text { Failure to Reduce CCW heat } \\
\text { Loads with One CCW Pump }\end{array}$ & $8.20 E-03$ & 1 & 5 & 30 \\
\hline ZHECT1 & $\begin{array}{l}\text { Failure to Restore AC Power } \\
\text { - Relay Chatter }\end{array}$ & $1.20 \mathrm{E}-02$ & 1 & 5 & 30 \\
\hline ZHECT2 & $\begin{array}{l}\text { Failure to Restore AC Power } \\
\text { - Relay Chatter, SLOCA, No } \\
\text { AFW }\end{array}$ & $1.30 \mathrm{E}-02$ & 1 & 5 & 30 \\
\hline ZHECT3 & $\begin{array}{l}\text { Failure to Restore AC Power } \\
\text { - Relay Chatter and No AFW }\end{array}$ & 1.10E-02 & 1 & 5 & 30 \\
\hline
\end{tabular}




\section{IPEEE Seismic Human Action : Method 2}

- Rates are a function of timing and access.

\begin{tabular}{||c|c|c|c||}
\hline $\begin{array}{c}\text { Seismic IPEEE } \\
\text { Performance Shaping } \\
\text { Factors }\end{array}$ & $\begin{array}{c}\text { short time period } \\
(\mathrm{t}<20 \mathrm{~min})\end{array}$ & $\begin{array}{c}\text { medium time period } \\
(20 \mathrm{~m}<\mathrm{t}<60 \mathrm{~m})\end{array}$ & $\begin{array}{c}\text { long time period } \\
(1 \mathrm{hr}<\mathrm{t}<24 \mathrm{hr})\end{array}$ \\
\hline \hline In control room action & 10 & 5 & 1 \\
\hline Ex-control room action & 30 & 10 & 5 \\
\hline
\end{tabular}




\section{Human Error Rates Used for in Seismic PRA}

- Rates are a function of seismic level

$<0.12 \mathrm{~g}$ (SSE); no change.

$0.12 \mathrm{~g}-.36 \mathrm{~g}$; linear increase to factor of 10 at $3^{\star} \mathrm{SSE}$.

$>.36 \mathrm{~g}$; failure probability $=1.0$. 


\section{SPRA Documentation}

- Level of SPRA documentation should follow new ANS Standard for External Event PRA.

- SPRA documentation should include:

- Description of methodology and key assumptions.

- Hazard curves used in analysis.

- Walkdown team, procedures and findings.

- Systems information (including non-seismic failures human actions modeling of screened out components, correlations and dependencies). 


\section{SPRA Documentation (Continued)}

- SPRA documentation should include (continued):

- List of fragility parameter values.

- Core damage fragility curve.

- Mean core damage frequency and ranking of contributors.

- Containment failures and performance insights.

- Results of evaluation and insights gained.

- Documentation regarding other seismic issues.

- Decay heat removal.

- Seismic/fire interaction.

- Inadvertent actuations of fire protection systems. 


\section{Example Results}

IVI Laboratory 


\section{Learning Objectives}

- After studying this section you should be able to:

- Interpret and understand the different presentation of results in a seismic PRA.

- Judge the reasonableness of sequence contributors given the list of detailed fragilities. 


\section{Example Results}

- Insights From Submittals

- Relative Importance to CDF

- Key Plant Damage States

- Key Sequence Groups

- Seismic Basic Event Importance 


\section{Seismic Core Damage Frequencies}

\begin{tabular}{|c|c|c|c|c|c|c|c|c|}
\hline Plant & Unit (34) & A-46 & Reactor Type & $\begin{array}{c}\text { Seismic } \\
\text { IPEEE } \\
\text { Approach }\end{array}$ & RLE & $\begin{array}{l}\text { Mean Seismic } \\
\text { CDF Per Year }\end{array}$ & $\begin{array}{c}\text { Ratio of Seismic CDF } \\
\text { to Internal CDF }\end{array}$ & $\begin{array}{c}\text { Seismic Hazard Used for } \\
\text { Base Case }\end{array}$ \\
\hline No. 03 & 1 & 嘼 & W-PWR & PRA & $0.3 \mathrm{~g}$ Focused & $9.07 \mathrm{E}-06$ & $7.75 \%$ & EPRI \\
\hline No. 04 & 2 & & W-PWR & PRA & $0.3 \mathrm{~g}$ Focused & $5.33 E-06$ & $8.90 \%$ & EPRI \\
\hline No. 10 & 1 & 圁 & C-E - PWR & PRA & $0.3 \mathrm{~g}$ Focused & $1.30 \mathrm{E}-05$ & $5.40 \%$ & Revised LLNL \\
\hline No. 11 & 2 & 渔 & C-E - PWR & PRA & $0.3 \mathrm{~g}$ Focused & $1.50 \mathrm{E}-05$ & $6.25 \%$ & Revised LLNL \\
\hline No. 12 & $1 \& 2$ & & W-PWR & PRA & $0.3 \mathrm{~g}$ Focused & $1.60 \mathrm{E}-05$ & $36.36 \%$ & EPRI \\
\hline No. 15 & $1 \& 2$ & 渔 & W-PWR & PRA & $0.3 \mathrm{~g}$ Focused & $1.83 E-05$ & $29.23 \%$ & Site-Specific \\
\hline No. 19 & $1 \& 2$ & & W-PWR & PRA & PRA & $4.00 \mathrm{E}-05$ & $45.45 \%$ & Site-Specific \\
\hline No. 29 & & 渔 & W-PWR & PRA & $0.3 \mathrm{~g}$ Focused & $2.26 \mathrm{E}-04$ & & EPRI \\
\hline No. 30 & & & GE-BWR & PRA & $0.3 \mathrm{~g}$ Focused & $1.00 \mathrm{E}-06$ & $2.16 \%$ & EPRI \\
\hline No. 31 & 2 & 䱣 & W-PWR & PRA & $0.3 \mathrm{~g}$ Full & $1.10 \mathrm{E}-05$ & $35.14 \%$ & EPRI \\
\hline No. 32 & 3 & 渔 & W-PWR & PRA & $0.3 \mathrm{~g} \mathrm{Full}$ & $5.30 \mathrm{E}-05$ & $120.45 \%$ & EPRI \\
\hline No. 33 & & 渔 & W-PWR & $\mathrm{PRA}$ & $0.3 \mathrm{~g}$ Focused & $1.10 \mathrm{E}-05$ & $16.54 \%$ & EPRI \\
\hline No. 37 & $1 \& 2$ & & W-PWR & PRA & $0.3 \mathrm{~g}$ Focused & $1.10 \mathrm{E}-05$ & $27.50 \%$ & EPRI \\
\hline No. 42 & 1 & 鿷 & GE-BWR & Margin \& PRA & $0.3 \mathrm{~g}$ Focused & $1.10 \mathrm{E}-06$ & $20.00 \%$ & EPRI \\
\hline No. 43 & 2 & & GE-BWR & Margin \& PRA & $0.3 \mathrm{~g}$ Focused & $2.50 \mathrm{E}-07$ & $0.81 \%$ & EPRI \\
\hline No. 46 & $1,2 \& 3$ & 鼠 & $B \& W-P W R$ & PRA & $0.3 \mathrm{~g}$ full & $3.60 \mathrm{E}-05$ & $156.52 \%$ & EPRI \\
\hline No. 47 & & 圖 & GE-BWR & PRA & $0.3 \mathrm{~g}$ Focused & $3.60 \mathrm{E}-06$ & $97.56 \%$ & EPRI \\
\hline No. 48 & & 圁 & C-E - PWR & PRA & $0.3 \mathrm{~g}$ Focused & $8.88 E-06$ & $17.20 \%$ & Revised LLNL \\
\hline No. 52 & & 嘼 & GE-BWR & PRA & $0.3 \mathrm{~g}$ Full & $5.82 E-05$ & $100.34 \%$ & EPRI \\
\hline No. 53 & $1 \& 2$ & 渔 & W-PWR & PRA & $0.3 \mathrm{~g}$ Focused & $1.31 \mathrm{E}-05$ & $12.17 \%$ & Revised LLNL \\
\hline No. $59 /$ No. 60 & $1 \& 2$ & 渔 & W-PWR & PRA & $0.3 \mathrm{~g}$ Full & $4.70 \mathrm{E}-06$ & $7.52 \%$ & EPRI \\
\hline No. 61 & $2 \& 3$ & 渔 & C-E - PWR & PRA & PRA & $1.70 \mathrm{E}-05$ & $56.67 \%$ & Site-Specific \\
\hline No. 62 & & & W-PWR & PRA & Full & $1.20 \mathrm{E}-05$ & $17.91 \%$ & Site-Specific \\
\hline No. 71 & 1 & 滖 & B\&W - PWR & PRA & $0.3 \mathrm{~g}$ Focused & $3.21 \mathrm{E}-05$ & $71.49 \%$ & EPRI \\
\hline No. 77 & 2 & & GE-BWR & PRA & $0.5 \mathrm{~g}$ & $2.00 \mathrm{E}-05$ & $114.29 \%$ & Site-Specific \\
\hline
\end{tabular}

Decommissioned 


\section{Mean Seismic CDF (EPRI, LLNL, Site Specific Hazard)}

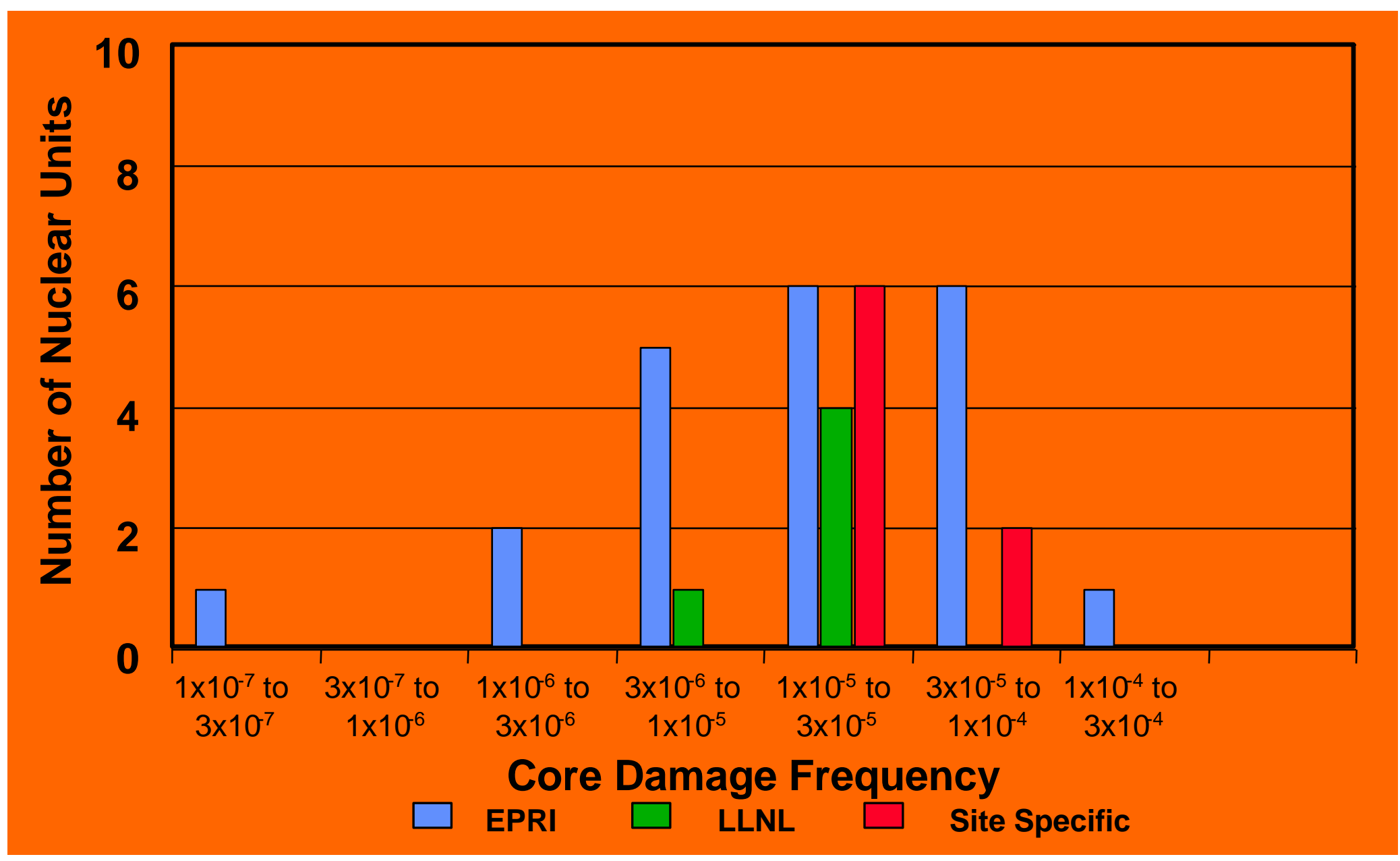




\section{Seismic/Internal Event CDF's}

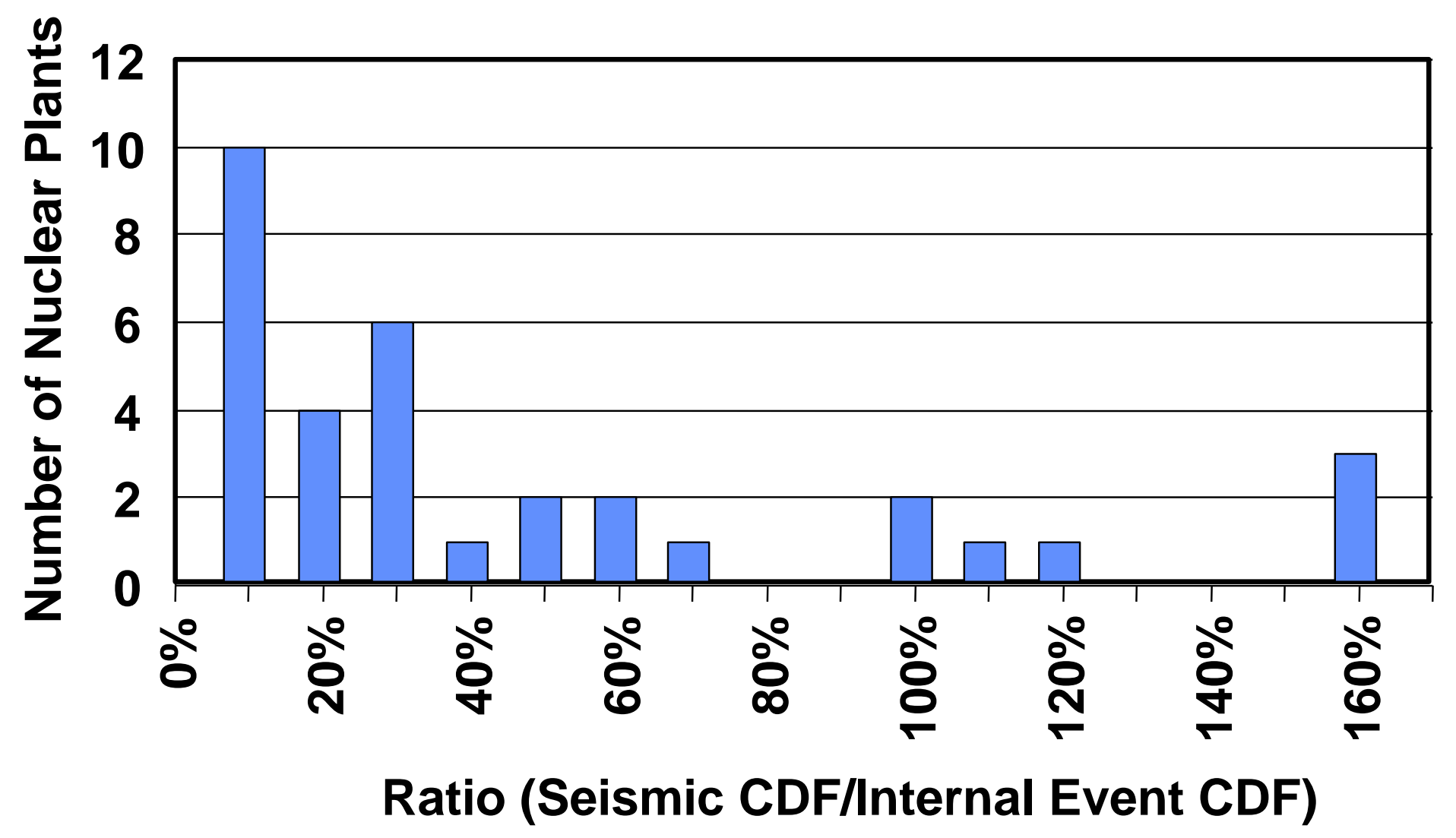

33 Plants 


\section{CDF Comparison: Plant Vintage}

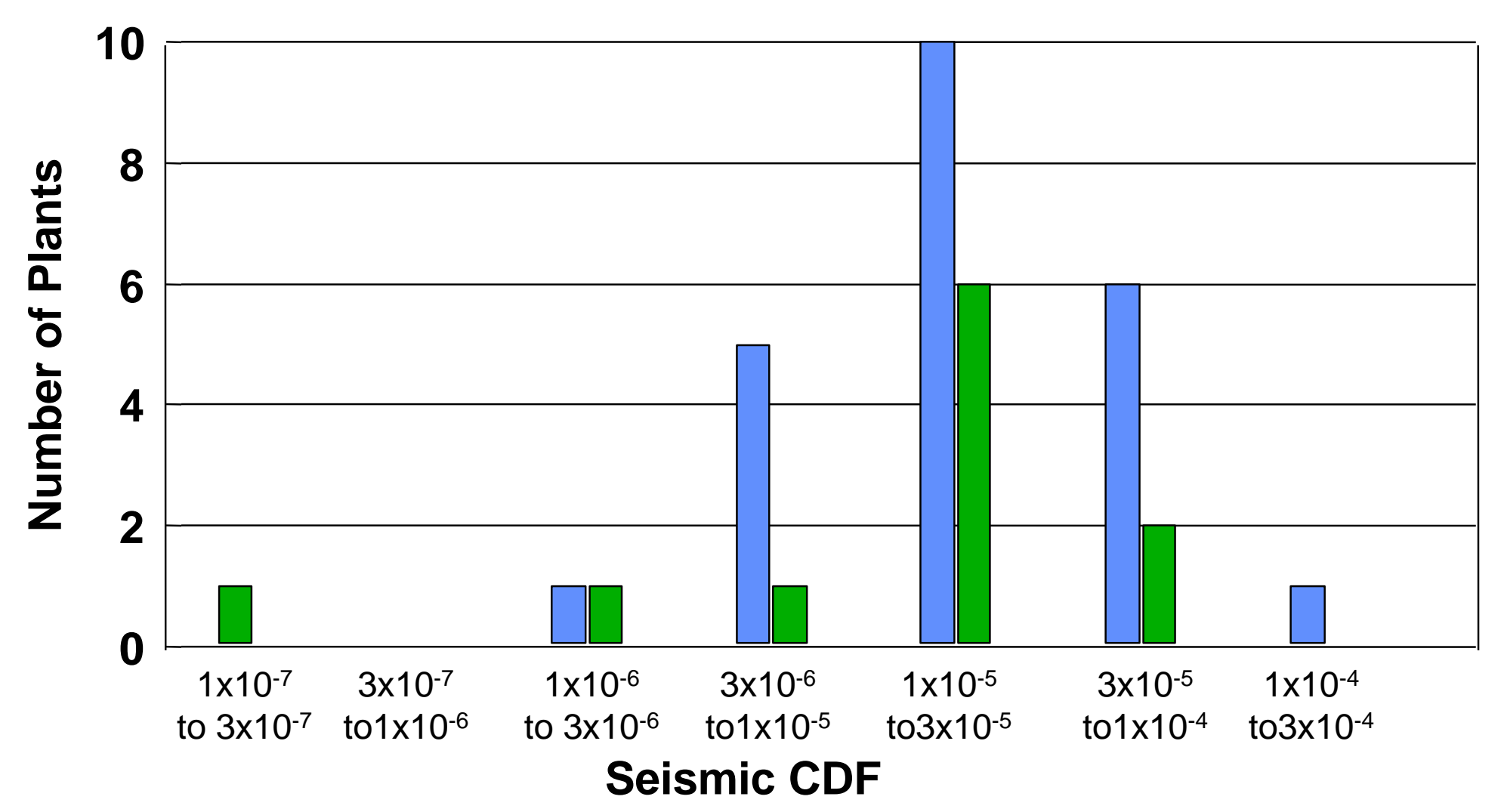

A-46 $\square$ Non A-46 


\section{Plant HCLPF Capacities: Plant Vintage}

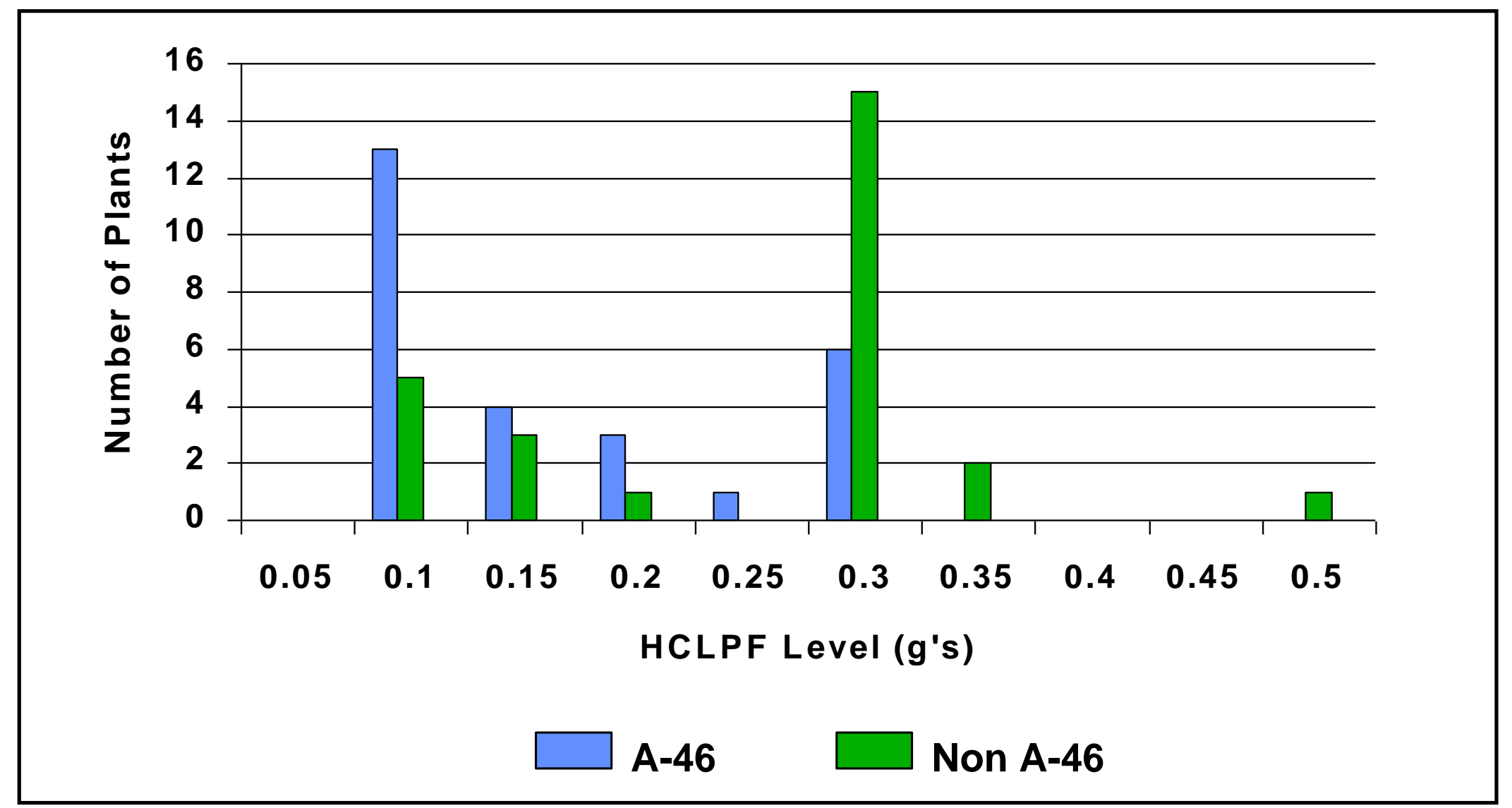




\section{IPEEE Seismic PRA Results Dominant Risk Contributors: Plant Systems}

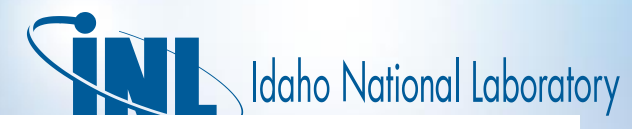

\begin{tabular}{|c|c|c|c|c|c|c|c|c|c|c|c|c|}
\hline Unit Code & 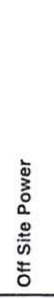 & 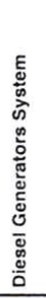 & 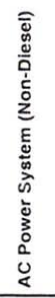 & 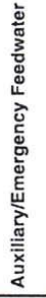 & 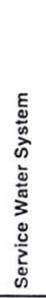 & 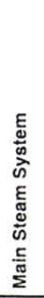 & 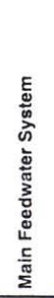 & 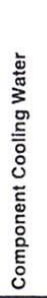 & 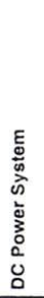 & 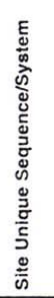 & 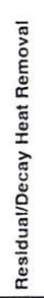 & $\begin{array}{l}\text { D } \\
\text { 足 }\end{array}$ \\
\hline 3 & $x$ & $x$ & & & & & & & $x$ & & & \\
\hline 4 & $x$ & $x$ & & & & & & & & & & \\
\hline $15 / 16$ & $x$ & & & & $x$ & & & & & & & \\
\hline $17 / 18$ & $x$ & $x$ & & & & & & & & & & \\
\hline $22 / 23$ & $x$ & & & & $x$ & $x$ & $x$ & & & & & \\
\hline $27 / 28$ & $x$ & & & & & & & & & & & \\
\hline $40^{\circ}$. & $x$ & $x$ & & $x$ & & & $x$ & & & & & \\
\hline 41 & & & $x$ & & & & & & $x$ & & & \\
\hline 42 & & & $x$ & & & & & $x$ & & & & \\
\hline 43 & $x$ & $x$ & $x$ & & & & & & & & $x$ & \\
\hline 44 & & & $x$ & & $x$ & & & & & & & $x$ \\
\hline $45 / 46$ & $x$ & & & & & & & & & & & \\
\hline $50 / 51$ & $x$ & $x$ & & & & & & & & & & \\
\hline 54 & $x$ & $x$ & & & & & & & & & $x$ & \\
\hline 56 & $x$ & $x$ & & & & & & & & & & \\
\hline 57 & $x$ & $x$ & & & & & & & & & & \\
\hline $60 / 61 / 62$ & $x$ & & $x$ & & & & & & & $x^{2}$ & & \\
\hline 63 & $x$ & $x$ & $x$ & $x$ & & & & & & & & \\
\hline 64 & $x$ & $x$ & & & & $x$ & & & & $x^{\prime}$ & & \\
\hline $71^{3}$ & & & & & & & & & & & & \\
\hline $72 / 73$ & $x$ & $x$ & $x$ & $x$ & & & & & & & & \\
\hline $81 / 82$ & $x$ & & & & $x$ & & & & $x$ & & & \\
\hline $83 / 84$ & $x$ & & $x$ & & & & & & & & & \\
\hline 85 & $x$ & $x$ & $x$ & & & & & & & & & \\
\hline $89 / 90$ & $x$ & $x$ & & & & & & & & & & \\
\hline $94 / 95$ & $x$ & & & & & & & & & $x^{4}$ & & \\
\hline 98 & $x$ & $x$ & $x$ & & & & & & & & & \\
\hline 107 & $x$ & $x$ & $x$ & & & & & & & & & \\
\hline Total Units $=41$ & 37 & 20 & 15 & 4 & 7 & 3 & 3 & 1 & 4 & 6 & 2 & 1 \\
\hline
\end{tabular}

- Decommissioned

Decommissioned
Fire Protection System Used As Makeup for CST

Refers to a Hydro Plant and a Safe Shutdown Facility for Emergency Power

Dom inant $R$ isk Contributors not defined in the subm ittal

seismic-induced damage to turbine building which leads to loss of cooling of emergency

switchgear room, changing pump, RHR heat exchanger, and recirculation spray. 


\section{IPEEE Seismic PRA Results Dominant Risk Contributors: Component Types}

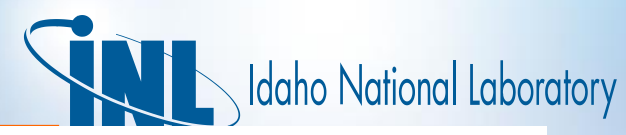

\begin{tabular}{|c|c|c|c|c|c|c|c|c|c|c|c|c|c|c|c|c|c|c|}
\hline Unit Code & 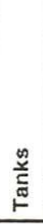 & $\begin{array}{l}\stackrel{\infty}{\frac{\pi}{0}} \\
\tilde{\Phi}\end{array}$ & $\begin{array}{l}\frac{\text { D }}{2} \\
\text { 음 }\end{array}$ & 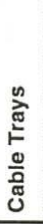 & 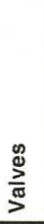 & 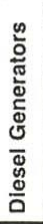 & 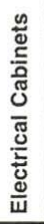 & 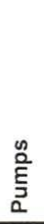 & 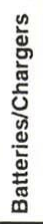 & 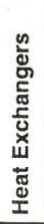 & 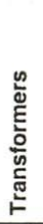 & 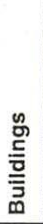 & 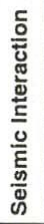 & 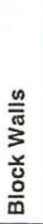 & 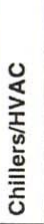 & 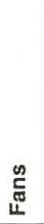 & 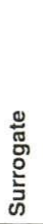 & 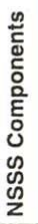 \\
\hline 3 & & & & & & & & & & & & & & $\mathrm{x}$ & & & & \\
\hline 4 & & & & & & $x$ & & & & & $x$ & $x$ & $x$ & & & & & \\
\hline $15 / 16$ & $x$ & & & & & & $x$ & & & & & & & & $\mathrm{x}$ & & $x$ & \\
\hline $17 / 18$ & $x$ & & & & & & $x$ & & $x$ & & & & & & & & & \\
\hline $22 / 23$ & $x$ & & & & & & & & & & $x$ & $\mathrm{x}$ & & & & & & \\
\hline $27 / 28$ & & $x$ & & & & & $x$ & & & & $x$ & $x$ & & & & & & \\
\hline $40^{*}$ & & & $x$ & & & & & & $x$ & & & & & & $\mathrm{x}$ & $x$ & & \\
\hline 41 & & & & & & & $x$ & & & & & & & & & & & \\
\hline 42 & $x$ & & & & & & & & & & & $x$ & $x$ & & & & & \\
\hline 43 & $x$ & & & & & & $x$ & $x$ & & & & & & & & & & \\
\hline 44 & & & & & & & & & & & & & & & & & $\mathrm{x}$ & \\
\hline $45 / 46$ & & & & & & & & & & & & & & & & & & \\
\hline $50 / 51$ & $x$ & & & & & & $x$ & & $x$ & & & & & & & & & \\
\hline 54 & $x$ & & & & & $\mathrm{x}$ & & & & & & $x$ & & & & & & $x$ \\
\hline 56 & $x$ & & & & & $x$ & & & & & & & & & & & $x$ & \\
\hline 57 & $x$ & & & & & $x$ & & & & & & & & & & & $x$ & \\
\hline $60 / 61 / 62$ & & & & & & & & & & & & & $x$ & & & & $\mathrm{x}$ & \\
\hline 63 & $x$ & & & & & $\mathrm{x}$ & & & & & & $x$ & & & & & & \\
\hline 64 & $x$ & & & & $\mathrm{x}$ & & $x$ & $x$ & & & & & & & & & & \\
\hline 71 & $x$ & & & & & & $x$ & $x$ & & & & $\mathrm{x}$ & $\mathrm{x}$ & $\mathrm{x}$ & & & & $x$ \\
\hline $72 / 73$ & & & & $\mathrm{x}$ & & & $x$ & & & & $x$ & & & & & & $x$ & \\
\hline $81 / 82$ & & & & & & & & & $x$ & & & & $x$ & & & $\mathrm{x}$ & & \\
\hline $83 / 84$ & & & & & & & $x$ & & & & $x$ & $x$ & & & & & $x$ & \\
\hline 85 & $x$ & & & & & $\mathrm{x}$ & $x$ & & & & & & & & & & & \\
\hline $89 / 90$ & $x$ & $x$ & & & & $x$ & $x$ & & & & & & & & & & & \\
\hline $94 / 95$ & $\mathrm{x}$ & & & & & & & & & & & $x$ & $x$ & & & & & \\
\hline 98 & $x$ & & & & & $\mathrm{x}$ & & & & $x$ & & & $x$ & & & & & $x$ \\
\hline 107 & & & & & & & $x$ & & & & & & & & & & $\mathrm{x}$ & \\
\hline Total Units $=41$ & 22 & 4 & 1 & 2 & 1 & 9 & 20 & 3 & 7 & 1 & 9 & 13 & 11 & 2 & 3 & 3 & 13 & 3 \\
\hline
\end{tabular}




\section{Insights from Seismic IPEEE Submittals}

- Need for sensitivity study of operator error rates.

- Fire sources often not clearly located.

- Degradation of fire suppression capability needs greater attention.

- Component screening criteria in a SPRA may not always be chosen sufficiently high. (Surrogate elements are significant contributors or are not included to represent screened out components.)

- Relay chatter effects not quantified for focused scope plants that conducted SPRA. 


\section{Insights from Seismic IPEEE Submittals (Continued)}

- CDFs range from $2.5 \times 10^{-7}$ to $2.3 \times 10^{-4}$ /year.

- Eastern site HCLPFs range from $0.09 \mathrm{~g}$ to $0.50 \mathrm{~g}$.

- Bad actor relays have often been found.

- Soil failures might be of concern (often screened out at lower level than component screening).

- Key failures frequently repeated.

- Seismic - Offsite Power, Electrical Panels, Block Walls, Tanks, Interactions, Structures

- Random - Diesel Generators

*after some modifications 


\section{Example - PRA Core Damage Frequency by Initiating Event}

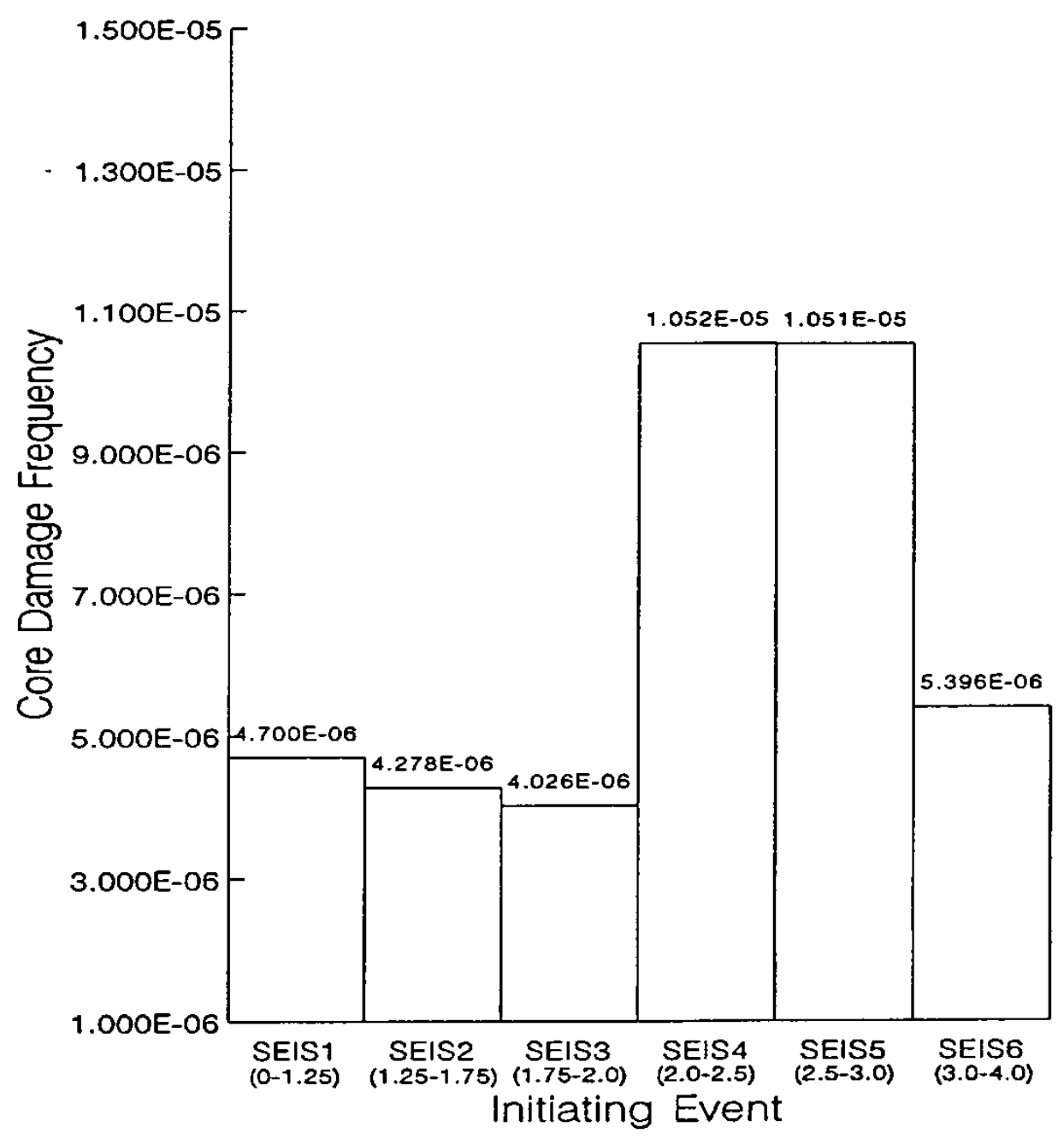




\section{Example - Plant Fragility Including Seismic} Failure and Random Failure Modes for Seismic

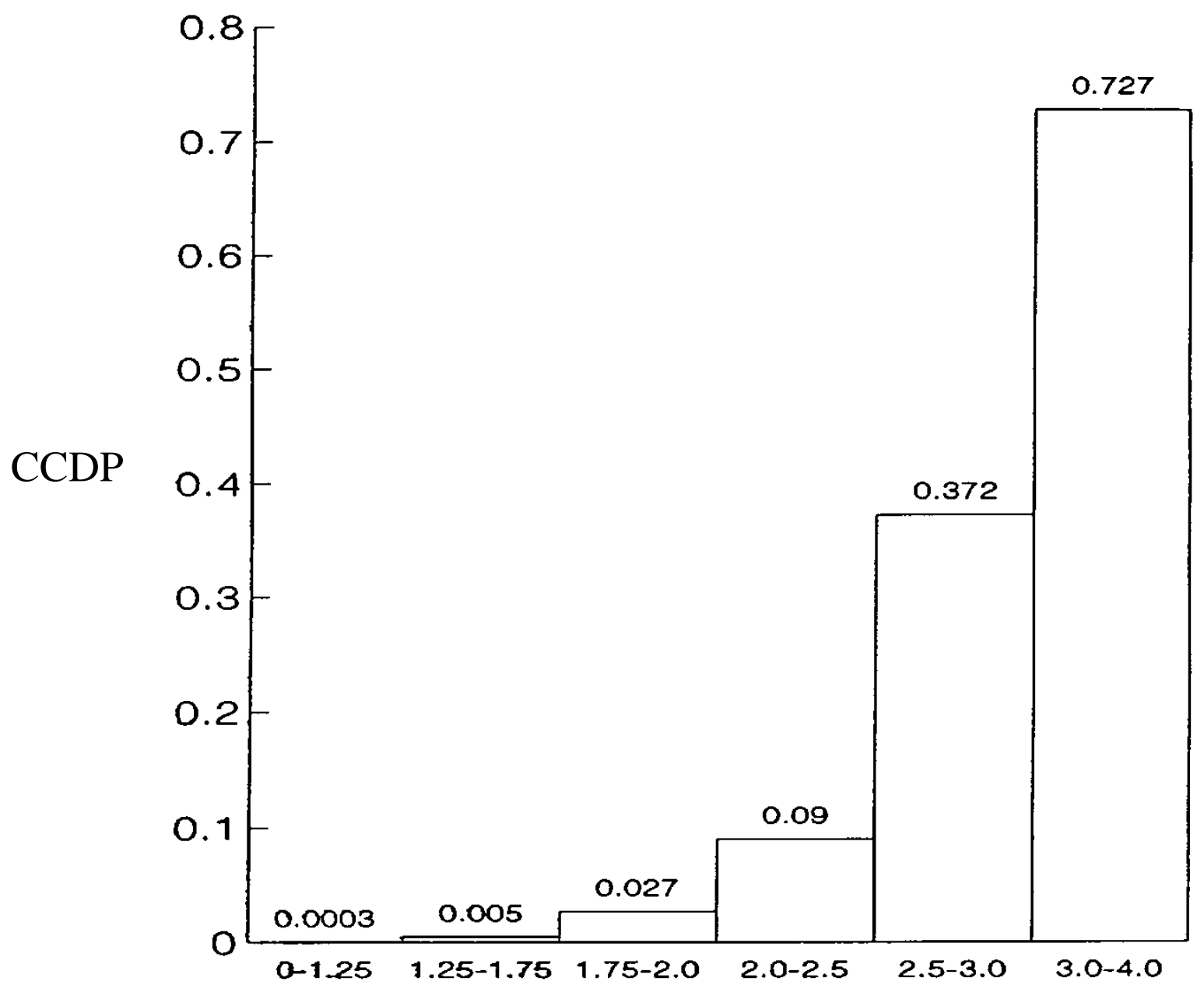




\section{Groups of Seismic Failures Contributing to Core Damage}

\begin{tabular}{|l|c|}
\hline \multicolumn{1}{|c|}{ Sequences Evaluated } & $\begin{array}{c}\text { Failure Frequency } \\
\text { (per year) }\end{array}$ \\
\hline Total Seismic Core Damage & $3.7 \times 10^{-5}$ \\
All 4.16-kV Vital AC Switchgear Fail & $1.7 \times 10^{-5}$ \\
Loss of Offsite Power & $1.2 \times 10^{-5}$ \\
Excessive LOCAs & $7.8 \times 10^{-6}$ \\
All Vital 125V DC Fails & $5.6 \times 10^{-6}$ \\
All 120V Vital Instrumentation Fails & $1.4 \times 10^{-6}$ \\
Relay Chatter with Failure To Recover & $1.2 \times 10^{-6}$ \\
Control Room Boards and Hot Shutdown Panel Fail & $9.7 \times 10^{-7}$ \\
\hline
\end{tabular}




\section{Uncertainty Results}

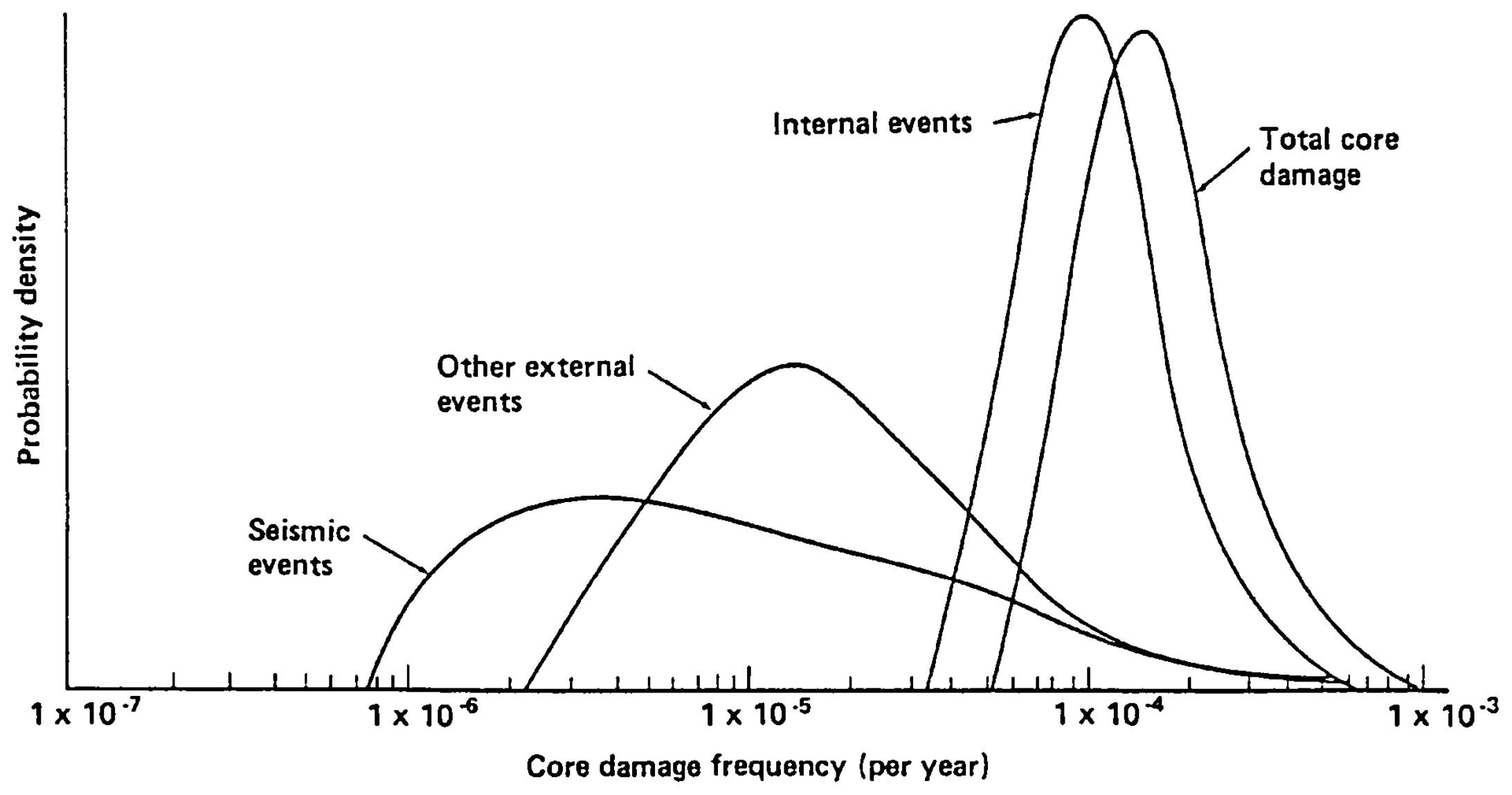




\section{Insights From Seismic IPEEEs}

- Utility personnel received seismic IPEEE training and generally had a significant participation in the seismic walkdown and evaluation process.

- Seismic walkdown performed for each plant was useful in identifying vulnerabilities.

- Where needed, potential adverse effects of relay chatter have been corrected.

- Containment safeguard equipment have generally been found to be rugged. 


\section{Insights From Seismic IPEEEs (Continued)}

- Simplifications in systems analysis and fragility analysis have limited insights to a qualitative nature.

- Risk reduction from plant improvements often not reported.

- The differences in hazard curves from different studies (LLNL and EPRI) generally do not change dominant contributor ranking (for some cases examined, the choice of hazard could make a significant difference).

- Different ground motion spectra used for PRA and margins, thus HCLPFs not comparable.

- Seismic-induced fires and floods have been addressed in all the plants to varying levels of detail. 


\section{Example Issues Identified in Seismic IPEEEs}

- Failure of toxic and flammable gas storage tanks.

- Collapse of nearby tall chimney or stack.

- Spatial interactions with columns or grating.

- Incorrectly supported piping between buildings.

- Amplification of ground motion at shallow soil sites.

- Unanchored equipment, such as DG day tanks and DG jacket water expansion tanks, don't meet design basis.

- Banging of unattached adjacent cabinets, causing potential relay chatter.

- Poor battery racks and poorly anchored cabinets.

- Non safety related structures can dominate CDF and LERF results. 


\section{Summary}

- Seismic PRA and seismic margin are useful tools to analyze beyonddesign-basis events.

- At many plants (including new plants), seismic reviews have identified some design, construction, and maintenance errors.

- Seismic reviews have also identified items with low seismic margin above the design basis earthquake, and identified cost-effective upgrades to improve plant seismic safety.

- Methodology and knowledge gained can be used for future risk informed decisions. 


\section{Summary (Continued)}

- Seismic reviews have been used to develop training and simulator scenarios, and also to identify changes to operating procedures to improve plant seismic safety.

- In addition to prioritizing seismic plant modifications, PRAs have been used to quantify the risk versus return and the cost effectiveness of modifications.

- IPEEE models and information can potentially be used for future riskinformed plant modifications or regulatory activities. 


\section{Summary (Continued)}

- ANS Standard for External Event PRA focused on risk informed decisions.

- IPEEE requirements focused on identifying vulnerabilities.

- IPEEE SPRA models will likely require enhancement for future risk informed applications.

- IPEEE SMA studies will require recasting into a quantitative risk model

- Develop fragilities from HCLPF calculations.

- Develop risk models from internal event PRA models. 


\section{Seismic PRA - SPAR 5 Bins Methodology}




\section{Seismic PRA - SPAR 5 Bins Methodology}

- United States Nuclear Regulatory Commission's (US NRC) move toward risk-informed regulation has increased emphasis on performing probabilistic risk assessments (PRA) for internal and external events.

- Recent domestic (i.e., revision of seismic hazard curves in the eastern US and Central Virginia Earthquake) and foreign developments (i.e., Tōhoku Earthquake and Tsunami) are expected to generate activity in reevaluation of seismic risk for US sites

- On-going efforts to expand and enhance the use of external events PRA tools for US NRC risk-informed reactor oversight activities 


\section{Seismic PRA - SPAR 5 Bins Methodology}

- Development of seismic framework for SPAR-EE models suitable for events assessment:

- Built efficiently

- Standardized modeling

- Uses readily available information

- Informed by current PRA standards and requirements, but focused on risk-insights for oversight activities

- Consistent with INL/NRC PRA software tools, i.e., Systems Analysis Programs for Hands-on Integrated Reliability Evaluations (SAPHIRE) quantification code (linked fault tree approach) 


\section{Seismic PRA - SPAR 5 Bins Methodology Seismic Hazard Curve}

USGS 2008

\begin{tabular}{|c|c|}
\hline $\begin{array}{c}\text { Ground Acceleration } \\
(\mathbf{g})\end{array}$ & $\begin{array}{c}\text { Exceedence Frequency } \\
\mathbf{( 1 / y r )}\end{array}$ \\
\hline 0.007 & $6.800 \mathrm{E}-03$ \\
\hline 0.0098 & $4.700 \mathrm{E}-03$ \\
\hline 0.0137 & $3.200 \mathrm{E}-03$ \\
\hline 0.0192 & $2.200 \mathrm{E}-03$ \\
\hline 0.0269 & $1.400 \mathrm{E}-03$ \\
\hline 0.0376 & $8.500 \mathrm{E}-04$ \\
\hline 0.0527 & $4.600 \mathrm{E}-04$ \\
\hline 0.0738 & $2.300 \mathrm{E}-04$ \\
\hline 0.103 & $1.100 \mathrm{E}-04$ \\
\hline 0.145 & $4.700 \mathrm{E}-05$ \\
\hline 0.203 & $2.200 \mathrm{E}-05$ \\
\hline 0.284 & $1.100 \mathrm{E}-05$ \\
\hline 0.397 & $5.600 \mathrm{E}-06$ \\
\hline 0.556 & $3.000 \mathrm{E}-06$ \\
\hline 0.778 & $1.500 \mathrm{E}-06$ \\
\hline 0.9 & $1.100 \mathrm{E}-06$ \\
\hline 1.09 & $7.300 \mathrm{E}-07$ \\
\hline 1.52 & $3.000 \mathrm{E}-07$ \\
\hline 2.13 & $9.100 \mathrm{E}-08$ \\
\hline
\end{tabular}




\section{Seismic PRA - SPAR 5 Bins Methodology Seismic Hazard Curve}

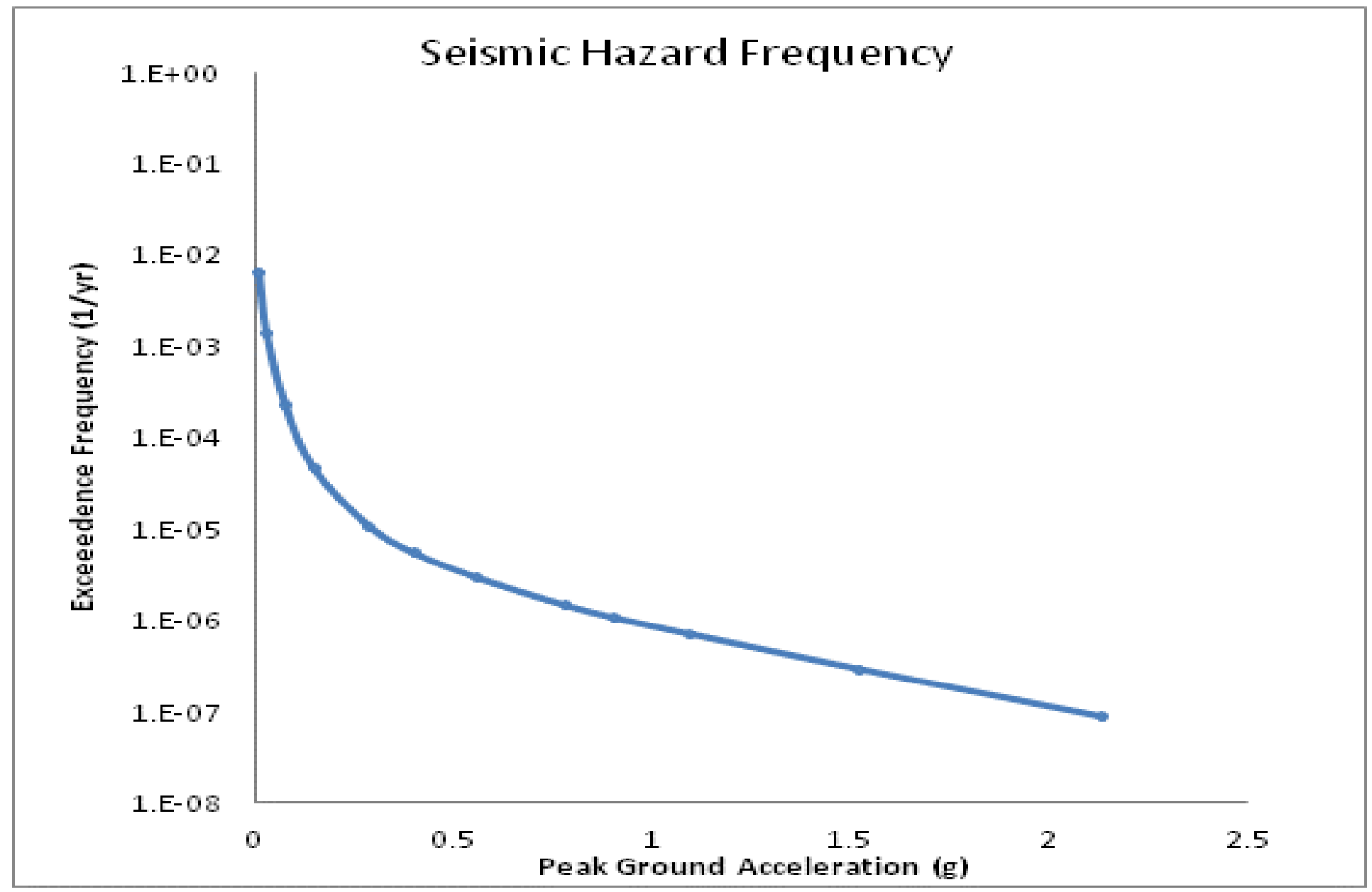




\title{
Seismic PRA - SPAR 5 Bins Methodology Development of Bins vs Frequency
}

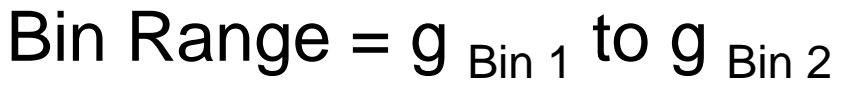

Bin Magnitude $(\mathrm{g})=\operatorname{Sqrt}\left(\mathrm{g}_{\operatorname{Bin} 1}{ }^{*} \mathrm{~g}_{\operatorname{Bin} 2}\right)$

Bin Frequency $(1 / y r)=$ Frequency $_{\text {Bin 1 }}-$ Frequency $_{\text {Bin } 2}$ 


\section{Seismic PRA - SPAR 5 Bins Methodology}

- Seismic hazard curve as an output from a probabilistic seismic hazard analysis (PSHA) or other sources

- Discretize hazard curve commensurate with level of detail expected from modeling approach

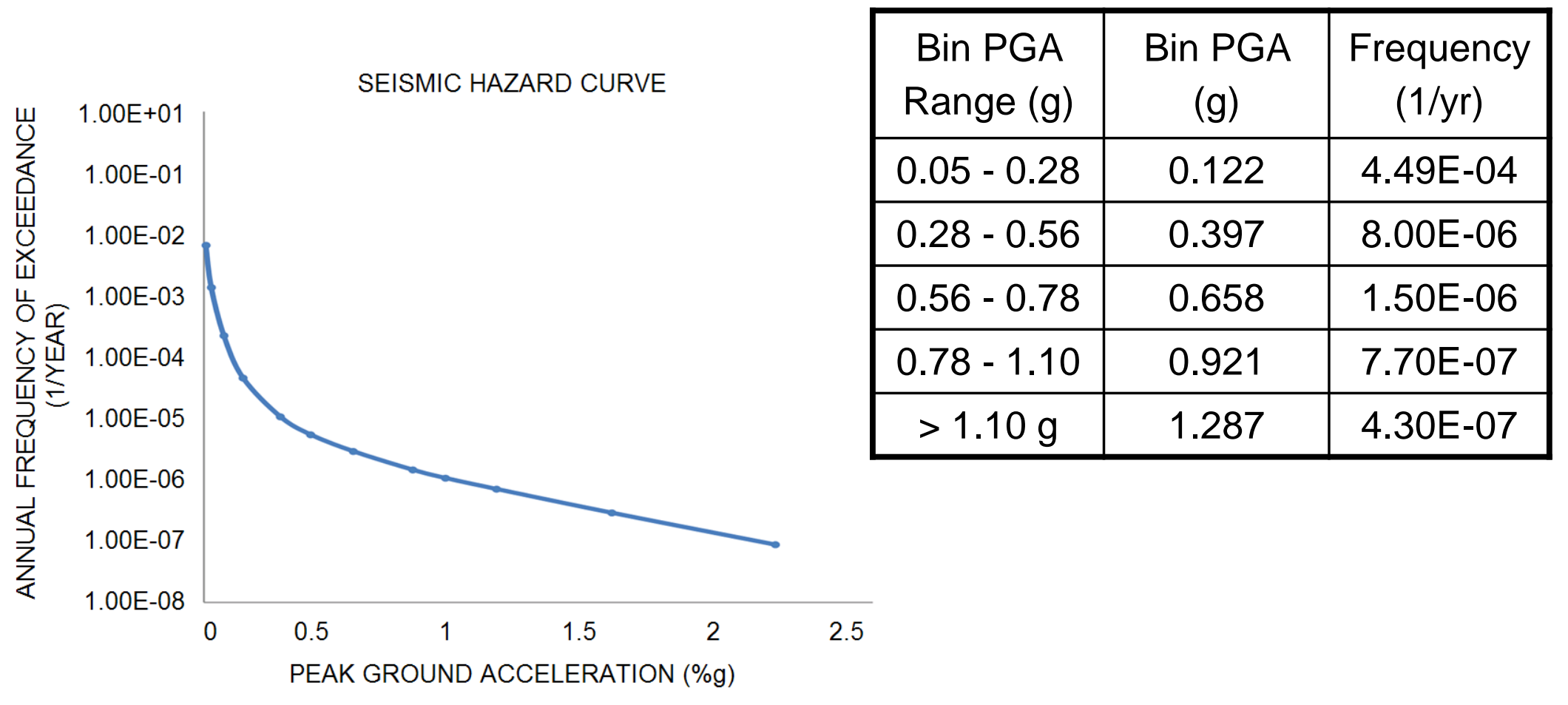




\section{Seismic PRA - SPAR 5 Bins Methodology Component Fragility Parameters}

\begin{tabular}{|c|c|c|c|c|c|}
\hline SSC Description & $\begin{array}{l}\text { Median } \\
\text { Capacity } \\
\text { (g) }\end{array}$ & $\beta_{r}$ & $\beta_{\mathrm{u}}$ & $\begin{array}{c}\text { SSC } \\
\text { HCLPF } \\
\text { (g) }\end{array}$ & SPAR Event \\
\hline ACCUMULATOR TANK & 1.13 & 0.29 & 0.35 & 0.39 & ACC-TNK-EQX-ACCUM \\
\hline DIVISION 1 AC POWER 6.9kV BUS & 1.17 & 0.24 & 0.25 & 0.52 & ACP-BAC-EQX-69KV \\
\hline 480V AC BUS Fails & 0.69 & 0.23 & 0.36 & 0.26 & ACP-BAC-EQX-480V \\
\hline AFW MDP PUMP & 1.07 & 0.24 & 0.32 & 0.42 & AFW-MDP-EQX-MDP \\
\hline AFW TDP PUMP & 0.68 & 0.30 & 0.30 & 0.30 & AFW-TDP-EQX-TDP \\
\hline CCW SURGE TANK & 0.75 & 0.21 & 0.30 & 0.32 & CCW-TNK-EQX-TANK \\
\hline CONDENSATE STORAGE TANK (!) & 0.75 & 0.21 & 0.30 & 0.32 & AFW-TNK-EQX-CDSTNK \\
\hline BRMT PUMP 3BR-E015 & 1.33 & 0.18 & 0.27 & 0.63 & ASI-MDP-EQX-3BRE015 \\
\hline ALTERNATE SEAL INJECTION PUMP & 1.33 & 0.18 & 0.27 & 0.63 & ASI-PDP-EQX-E001 \\
\hline CCW MDP & 1.33 & 0.18 & 0.27 & 0.63 & CCW-MDP-EQX-CWMDP \\
\hline CCW HTX & 0.83 & 0.24 & 0.29 & 0.35 & CCW-HTX-EQX-CWHTX \\
\hline CCW RCP HTX & 0.83 & 0.24 & 0.29 & 0.35 & CCW-HTX-EQX-RCHTX \\
\hline CDS MDP & 1.40 & 0.25 & 0.37 & 0.50 & CDS-MDP-EQX-MDP \\
\hline DIV 1 BATTERY CHARGER & 0.51 & 0.321 & 0.321 & 0.18 & DCP-BCH-EQX-BTCHG \\
\hline NON VITAL 125VDC BUS & 1.02 & 0.20 & 0.42 & 0.37 & DCP-BDC-EQX-125V \\
\hline AIR COND UNIT & 1.40 & 0.25 & 0.37 & 0.50 & ECW-MDP-EQX-MDP \\
\hline HVAC FAN FOR AHU & 0.75 & 0.21 & 0.21 & 0.37 & ECW-FAN-EQX-CHFAN \\
\hline CHILLED WATER PUMP & 1.40 & 0.25 & 0.37 & 0.50 & ECW-CHL-EQX-CHLR \\
\hline DIESEL GENERATOR & 1.07 & 0.30 & 0.30 & 0.40 & EPS-DGN-EQX-DGNS \\
\hline
\end{tabular}




\section{Seismic PRA - SPAR 5 Bins Methodology Component Fragility Parameters}

\begin{tabular}{|c|c|c|c|c|c|c|}
\hline & & Bin 1 & Bin 2 & Bin 3 & Bin 4 & Bin 5 \\
\hline SSC Description & SPAR Event & 0.122 & 0.400 & 0.660 & 0.920 & 1.290 \\
\hline ACCUMULATOR TANK & ACC-TNK-EQX-ACCUM & $4.86 \mathrm{E}-07$ & $1.12 \mathrm{E}-02$ & $1.18 \mathrm{E}-01$ & $3.26 \mathrm{E}-01$ & $6.15 \mathrm{E}-01$ \\
\hline DIVISION 1 AC POWER 6.9kV BUS & ACP-BAC-EQX-69KV & $3.43 \mathrm{E}-11$ & $9.77 \mathrm{E}-04$ & $4.93 \mathrm{E}-02$ & $2.44 \mathrm{E}-01$ & $6.11 \mathrm{E}-01$ \\
\hline 480V AC BUS Fails & ACP-BAC-EQX-480V & $2.50 \mathrm{E}-05$ & $1.01 \mathrm{E}-01$ & 4.59E-01 & $7.50 \mathrm{E}-01$ & $9.28 \mathrm{E}-01$ \\
\hline AFW MDP PUMP & AFW-MDP-EQX-MDP & $2.84 \mathrm{E}-08$ & $6.95 \mathrm{E}-03$ & $1.14 \mathrm{E}-01$ & $3.53 \mathrm{E}-01$ & $6.80 \mathrm{E}-01$ \\
\hline AFW TDP PUMP & AFW-TDP-EQX-TDP & $2.57 \mathrm{E}-05$ & $1.06 \mathrm{E}-01$ & $4.72 \mathrm{E}-01$ & $7.62 \mathrm{E}-01$ & $9.34 \mathrm{E}-01$ \\
\hline CCW SURGE TANK & CCW-TNK-EQX-TANK & $3.54 \mathrm{E}-07$ & $4.30 \mathrm{E}-02$ & $3.64 \mathrm{E}-01$ & $7.12 \mathrm{E}-01$ & $9.31 \mathrm{E}-01$ \\
\hline CONDENSATE STORAGE TANK (!) & AFW-TNK-EQX-CDSTNK & $3.54 \mathrm{E}-07$ & $4.30 \mathrm{E}-02$ & $3.64 \mathrm{E}-01$ & $7.12 \mathrm{E}-01$ & $9.31 \mathrm{E}-01$ \\
\hline BRMT PUMP 3BR-E015 & ASI-MDP-EQX-3BRE015 & $9.07 \mathrm{E}-14$ & $1.07 \mathrm{E}-04$ & $1.54 \mathrm{E}-02$ & $1.28 \mathrm{E}-01$ & $4.63 \mathrm{E}-01$ \\
\hline ALTERNATE SEAL INJECTION PUMP & ASI-PDP-EQX-E001 & $9.07 \mathrm{E}-14$ & $1.07 \mathrm{E}-04$ & $1.54 \mathrm{E}-02$ & $1.28 \mathrm{E}-01$ & $4.63 \mathrm{E}-01$ \\
\hline CCW MDP & CCW-MDP-EQX-CWMDP & $9.07 \mathrm{E}-14$ & $1.07 \mathrm{E}-04$ & 1.54E-02 & $1.28 \mathrm{E}-01$ & $4.63 \mathrm{E}-01$ \\
\hline CCW HTX & CCW-HTX-EQX-CWHTX & $1.76 \mathrm{E}-07$ & $2.62 \mathrm{E}-02$ & $2.71 \mathrm{E}-01$ & $6.08 \mathrm{E}-01$ & $8.79 \mathrm{E}-01$ \\
\hline CCW RCP HTX & CCW-HTX-EQX-RCHTX & $1.76 \mathrm{E}-07$ & $2.62 \mathrm{E}-02$ & $2.71 \mathrm{E}-01$ & $6.08 \mathrm{E}-01$ & $8.79 \mathrm{E}-01$ \\
\hline CDS MDP & CDS-MDP-EQX-MDP & $2.32 \mathrm{E}-08$ & $2.51 \mathrm{E}-03$ & $4.61 \mathrm{E}-02$ & $1.74 \mathrm{E}-01$ & $4.27 \mathrm{E}-01$ \\
\hline DIV 1 BATTERY CHARGER & DCP-BCH-EQX-BTCHG & $8.14 \mathrm{E}-04$ & $2.96 \mathrm{E}-01$ & $7.15 \mathrm{E}-01$ & $9.03 \mathrm{E}-01$ & $9.80 \mathrm{E}-01$ \\
\hline NON VITAL 125VDC BUS & DCP-BDC-EQX-125V & $2.50 \mathrm{E}-06$ & $2.21 \mathrm{E}-02$ & $1.75 \mathrm{E}-01$ & $4.12 \mathrm{E}-01$ & $6.93 \mathrm{E}-01$ \\
\hline AIR COND UNIT & ECW-MDP-EQX-MDP & $2.32 \mathrm{E}-08$ & $2.51 \mathrm{E}-03$ & 4.61E-02 & $1.74 \mathrm{E}-01$ & 4.27E-01 \\
\hline HVAC FAN FOR AHU & ECW-FAN-EQX-CHFAN & $8.26 \mathrm{E}-10$ & $1.85 \mathrm{E}-02$ & $3.36 \mathrm{E}-01$ & $7.51 \mathrm{E}-01$ & $9.64 \mathrm{E}-01$ \\
\hline CHILLED WATER PUMP & ECW-CHL-EQX-CHLR & $2.32 \mathrm{E}-08$ & $2.51 \mathrm{E}-03$ & $4.61 \mathrm{E}-02$ & $1.74 \mathrm{E}-01$ & $4.27 \mathrm{E}-01$ \\
\hline DIESEL GENERATOR & EPS-DGN-EQX-DGNS & $1.54 \mathrm{E}-07$ & $1.02 \mathrm{E}-02$ & $1.27 \mathrm{E}-01$ & $3.61 \mathrm{E}-01$ & $6.70 \mathrm{E}-01$ \\
\hline
\end{tabular}




\section{Seismic PRA - SPAR 5 Bins Methodology}

- Limited component screening performed based on past modeling and operational experience, seismic ruggedness and available data

- Component fragilities of major SSCs obtained from large database of site-specific and generic values 


\section{Seismic PRA - SPAR 5 Bins Methodology}

- Seismically-induced initiating event categories defined hierarchically in event tree modeling for each bin

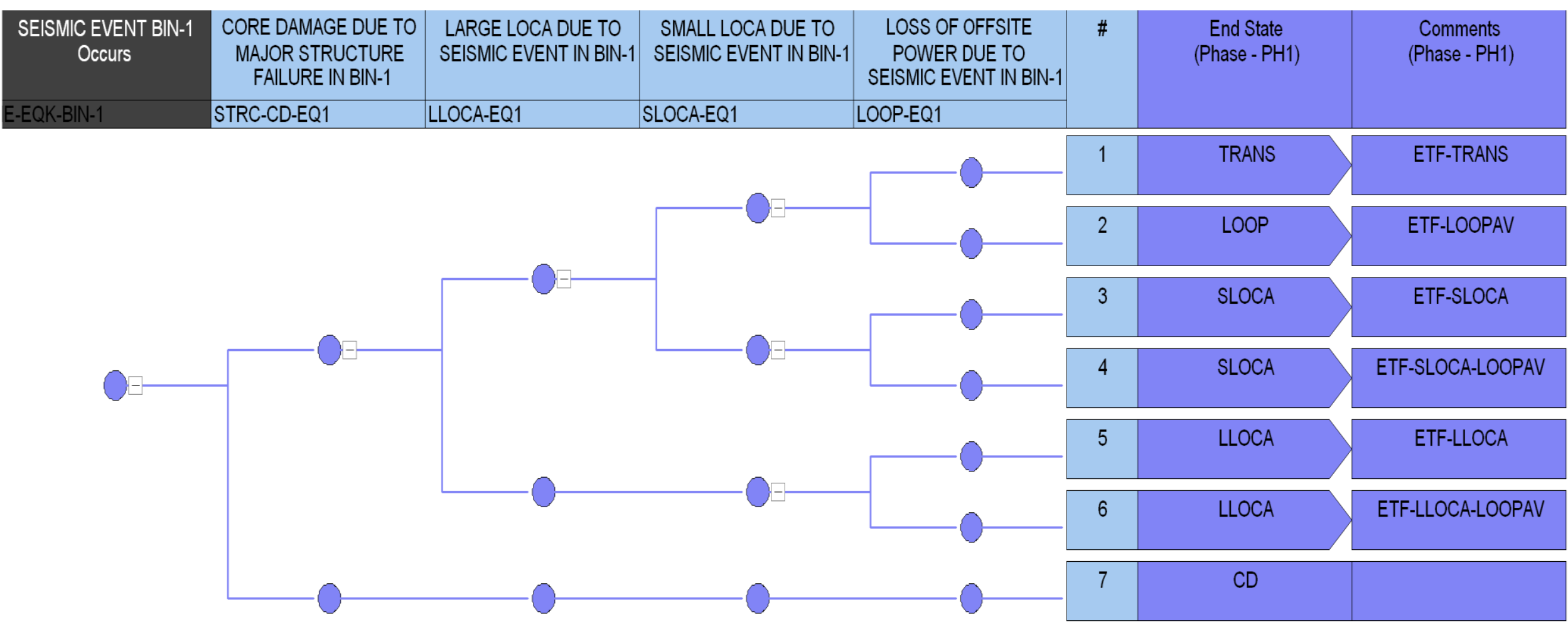




\section{Seismic PRA - SPAR 5 Bins Methodology}

PRA Level 1 fault trees modified to include seismic failure modes, connected to fault tree via event tree rules

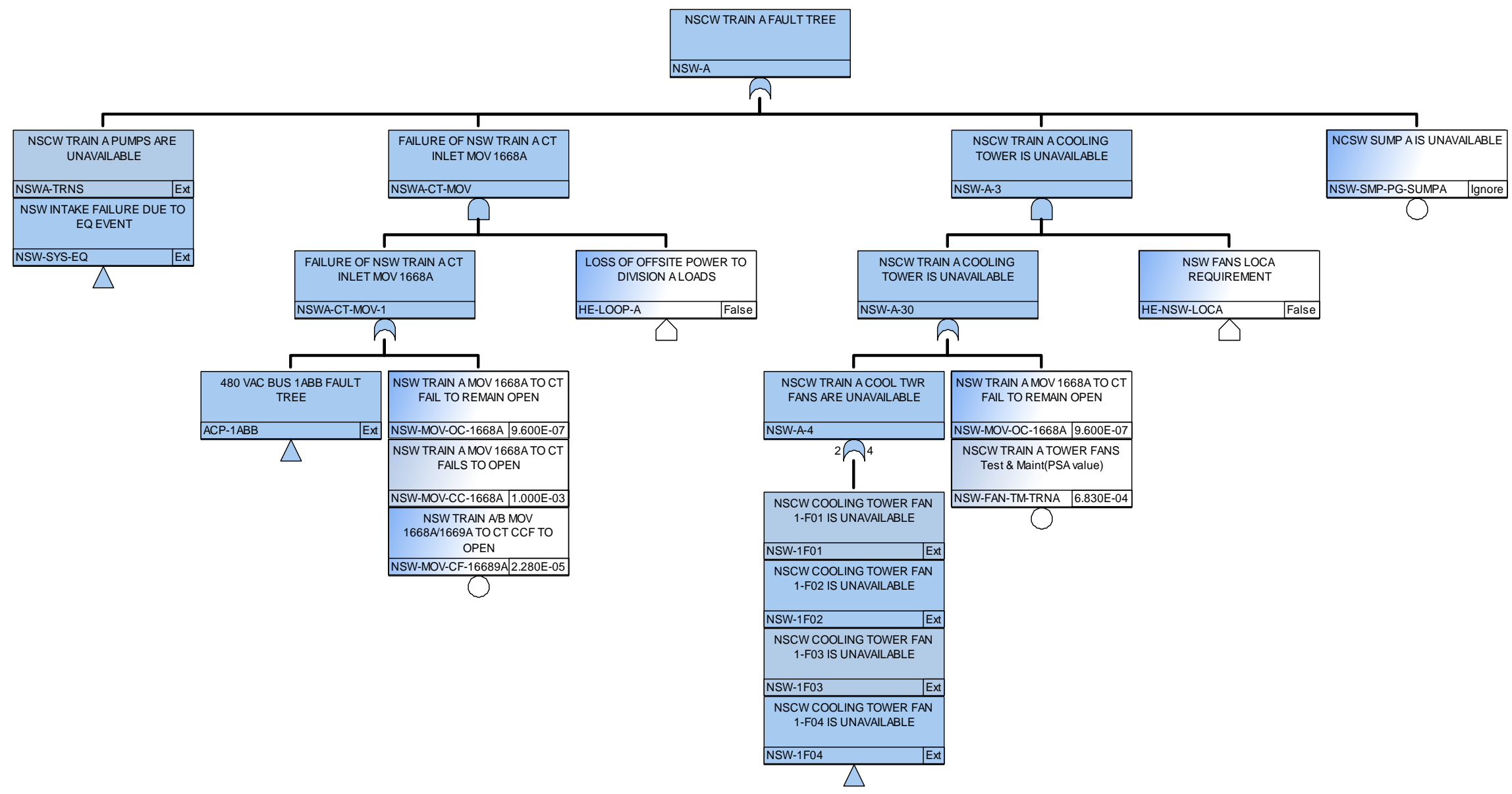




\section{Seismic PRA - SPAR 5 Bins Methodology}

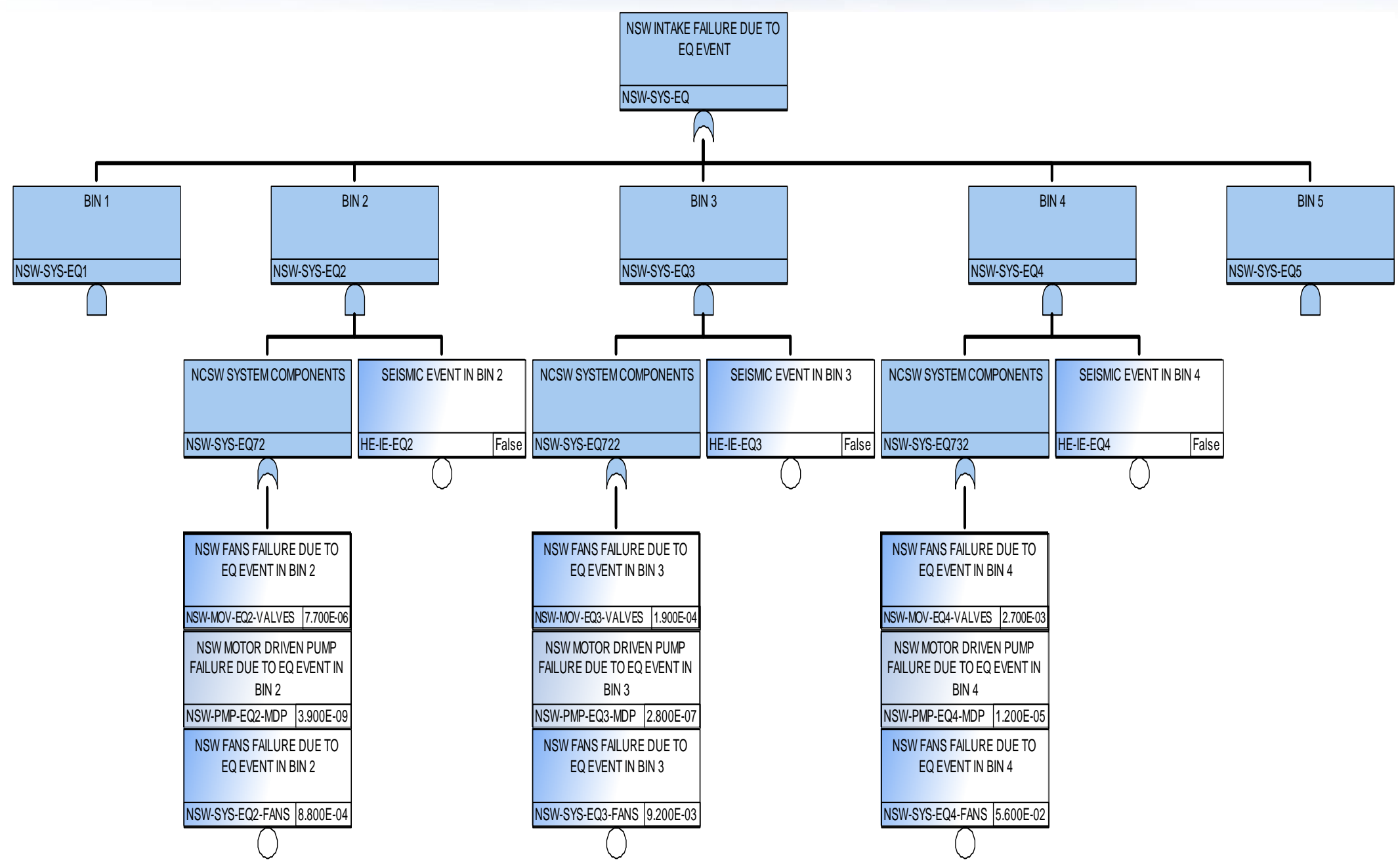




\section{Seismic PRA - SPAR 5 Bins Methodology}

\begin{tabular}{|c|c|c|c|c|c|}
\hline Name & Description & Prob & CDF & CCDP & Count \\
\hline IE-EQK-BIN-1 & SEISMIC EVENT IN BIN 1 (0.1 - 0.5g) OCCURS (BIN PGA 0.224) & $2.52 \mathrm{E}-03$ & $3.24 \mathrm{E}-07$ & $1.28 \mathrm{E}-04$ & 5417 \\
\hline IE-EQK-BIN-2 & SEISMIC EVENT IN BIN 2 (0.5 - 0.75g) OCCURS (BIN PGA 0.612) & $1.08 \mathrm{E}-04$ & $2.60 \mathrm{E}-06$ & $2.40 \mathrm{E}-02$ & 2241 \\
\hline IE-EQK-BIN-3 & SEISMIC EVENT IN BIN $3(0.75-1.0 \mathrm{~g})$ OCCURS (BIN PGA 0.866) & $2.80 \mathrm{E}-05$ & $2.79 \mathrm{E}-06$ & $9.98 \mathrm{E}-02$ & 1289 \\
\hline IE-EQK-BIN-4 & SEISMIC EVENT IN BIN 4 (1.0 - 1.5g) OCCURS (BIN PGA 1.22) & $1.17 \mathrm{E}-05$ & $3.84 \mathrm{E}-06$ & $3.29 \mathrm{E}-01$ & 968 \\
\hline IE-EQK-BIN-5 & SEISMIC EVENT IN BIN 5 (> 1.5g) OCCURS (BIN PGA 2.12) & $1.57 \mathrm{E}-06$ & $1.42 \mathrm{E}-06$ & $9.05 \mathrm{E}-01$ & 501 \\
\hline & SUM & & $1.10 \mathrm{E}-05$ & & \\
\hline
\end{tabular}

- Overall seismic contribution to Core Damage Frequency (CDF) similar in magnitude to internal events results

- Cut set results dominated by structural failures leading directly to core damage

- Bin 4 and 5, CCDP approaches to unity

- Bin 2 and 3 events compounded by random failures 


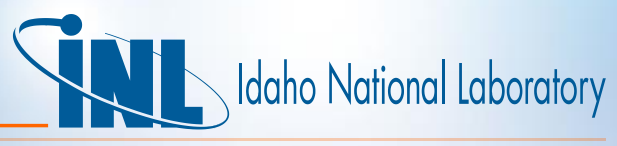

\section{Seismic PRA - SPAR 5 Bins Methodology}

- Importance measures calculated for individual basic events: FussellVesely (FV), Risk Increase Ratio (RIR), Risk Reduction Ration (RRR), and Birnbaum measure

\begin{tabular}{|c|c|c|c|c|c|}
\hline DESCRIPTION & Prob & FV & RIR & RRR & Birnbaum \\
\hline CORE DAMAGE DUE TO FAILURE OF CRITICAL INFRA STRUCTURES IN BIN-1 & $8.26 \mathrm{E}-10$ & $1.11 \mathrm{E}-07$ & 135.0 & 1.00 & $4.49 \mathrm{E}-04$ \\
\hline CORE DAMAGE DUE TO REACTOR INTERNAL AND CORE ASSEMBLY FAILURE IN BIN-1 & $6.94 \mathrm{E}-06$ & $9.29 \mathrm{E}-04$ & 135.0 & 1.00 & 4.49E-04 \\
\hline CORE DAMAGE DUE TO REATOR COOLANT PIPING FAILURE IN BIN-1 & $3.22 \mathrm{E}-08$ & 4.31E-06 & 135.0 & 1.00 & 4.49E-04 \\
\hline CORE DAMAGE DUE TO REACTOR PRESSURE VESSEL FAILURE IN BIN-1 & 1.13E-06 & 1.51E-04 & 135.0 & 1.00 & 4.49E-04 \\
\hline NON VITAL 125VDC BUS FAILS DUE TO EQ EVENT IN BIN 1 & $2.50 \mathrm{E}-06$ & $3.33 \mathrm{E}-04$ & 131.0 & 1.00 & $4.35 \mathrm{E}-04$ \\
\hline CCF 10 OR MORE RCCAS FAIL TO DROP & $1.21 \mathrm{E}-06$ & 1.94E-05 & 15.9 & 1.00 & $4.98 \mathrm{E}-05$ \\
\hline ATWS DUE TO SEISMIC EVENT IN BIN 1 & $6.94 \mathrm{E}-06$ & 1.03E-04 & 15.2 & 1.00 & $4.75 \mathrm{E}-05$ \\
\hline SEISMIC EVENT BIN-1 $(0.05 \mathrm{~g}-0.28 \mathrm{~g})$ Occurs (BIN ACCELARATION =0.122g) & 4.49E-04 & 1.65E-03 & 4.7 & 1.00 & 1.23E-05 \\
\hline CORE DAMAGE DUE TO REACTOR INTERNAL AND CORE ASSEMBLY FAILURE IN BIN-2 & 2.04E-02 & 4.86E-02 & 3.1 & 1.05 & 7.28E-06 \\
\hline CORE DAMAGE DUE TO FAILURE OF CRITICAL INFRA STRUCTRES IN BIN-2 & 1.85E-02 & 4.41E-02 & 3.1 & 1.04 & 7.27E-06 \\
\hline CORE DAMAGE DUE TO REACTOR PRESSURE VESSEL FAILURE IN BIN-2 & $3.19 \mathrm{E}-03$ & $7.61 \mathrm{E}-03$ & 3.1 & 1.01 & $7.16 \mathrm{E}-06$ \\
\hline CORE DAMAGE DUE TO STEAM GENRATOR SUPPORT FAILURE IN BIN-2 & 8.57E-06 & 2.04E-05 & 3.1 & 1.00 & 7.13E-06 \\
\hline CORE DAMAGE DUE TO REATOR COOLANT PIPING FAILURE IN BIN-2 & 2.71E-04 & $6.46 \mathrm{E}-04$ & 3.1 & 1.00 & 7.13E-06 \\
\hline NON VITAL 125VDC BUS FAILS DUE TO EQ EVENT IN BIN 2 & 2.21E-02 & $5.05 E-02$ & 2.4 & 1.05 & 4.90E-06 \\
\hline CCF OF RTB-A AND RTB-B (MECHANICAL) & $1.61 \mathrm{E}-06$ & $2.20 \mathrm{E}-06$ & 2.4 & 1.00 & $4.57 \mathrm{E}-06$ \\
\hline ATWS DUE TO SEISMIC EVENT IN BIN 2 & 2.04E-02 & $3.39 \mathrm{E}-02$ & 2.1 & 1.03 & $3.76 \mathrm{E}-06$ \\
\hline FAILURE OF CONDENSATE STORAGE TANK DUE TO EQ EVENT IN BIN 2 & $4.30 \mathrm{E}-02$ & $6.03 E-02$ & 2.0 & 1.06 & $3.42 \mathrm{E}-06$ \\
\hline COMMON CAUSE FAILURE OF BATTERIES & 4.99E-07 & $6.03 E-07$ & 1.9 & 1.00 & 2.97E-06 \\
\hline SMALL LOCA DUE TO SEISMIC EVENT IN BIN-2 & $2.80 \mathrm{E}-02$ & 2.47E-02 & 1.7 & 1.02 & 2.27E-06 \\
\hline CCF 6 BISTABLES IN 3 OF 4 CHANNELS & $2.70 \mathrm{E}-06$ & $1.78 \mathrm{E}-06$ & 1.7 & 1.00 & $2.21 \mathrm{E}-06$ \\
\hline
\end{tabular}




\section{Seismic PRA - SPAR 5 Bins Methodology}

- Seismic PRA framework developed and implemented for both current and new US commercial reactors in SAPHIRE software environment

- Software capable of using input seismic hazard curve, fragility information to develop insights into overall results, major contributors and sensitivity analysis

- Application of methodology provides a mechanism to evaluate risk for US operational events and determination of individual component safety significance worth 


\section{Fire Risk Analysis History}




\section{Fire PRA History}

- Appendix R to Part 50 - Fire Protection Program for Nuclear Power Facilities Operating Prior to January 1, 1979

Three levels of fire damage limits are established according to the safety functions of the structure, system, or component:

\begin{tabular}{|l|l|}
\hline \multicolumn{1}{|c|}{ Safety function } & \multicolumn{1}{c|}{ Fire damage limits } \\
\hline Hot Shutdown & $\begin{array}{l}\text { One train of equipment necessary to achieve hot shutdown from either } \\
\text { the control room or emergency control station(s) must be maintained } \\
\text { free of fire damage by a single fire, including an exposure fire. }\end{array}$ \\
\hline Cold Shutdown & $\begin{array}{l}\text { Both trains of equipment necessary to achieve cold shutdown may be } \\
\text { damaged by a single fire, including an exposure fire, but damage must } \\
\text { be limited so that at least one train can be repaired or made operable } \\
\text { within } 72 \text { hours using onsite capability. }\end{array}$ \\
\hline Design Basis Accidents & $\begin{array}{l}\text { Both trains of equipment necessary for mitigation of consequences } \\
\text { following design basis accidents may be damaged by a single exposure } \\
\text { fire. }\end{array}$ \\
\hline
\end{tabular}

- Plants licensed to operate after January 1,1979, are required to comply with 10 CFR 50.48(a), as well as any plant-specific fire protection license conditions and technical specifications. 


\section{Fire PRA History}

- WASH-1400

- Risk Judged to be negligible

- 2001 NFPA-805; Performance based Standards for Fire protection for LWR

- 2004 NRC Amended requirements: Voluntary adoption of NFPA-805

- 2005 NUREG/CR-6850; Guidance on quantification of fire risk (EPRI)

- 2007 NRC-EPRI, V\&Ved of Five fire model tools per NFPA-805

- 2012 NUREG/CR 1934 - NPP Fire Modeling Analysis Guidelines 


\section{Fire Risk Analysis Introduction}




\section{What is a "Fire"?}

- Fire occurs within the plant

- Fire results in plant trip

- Fire causes systems needed for safe shutdown to become unavailable - Increases likelihood of core damage

- Sometimes referred to as:

- External Event

- Internal Fire

- Fires external to the plant boundary have generally been judged to be not risk significant. 


\section{Questions Commonly Asked in Fire Risk Analysis}

- Where and how much:

- Ignition Sources

- Combustible Loading

- Critical Components

- Are there any room features that affect fire growth?

- Can a fire grow to a size that can damage the critical components in its vicinity?

- If a fire can potentially damage critical components in its vicinity, when will it happen?

- Fire is a horse race between damage and suppression 


\section{Fire Area vs. Fire compartment}

- Fire area - portion of building that is separated from other areas by a rated fire barrier (per Reg Guide 1.189)

- Fire compartment - enclosed room where a fire would be expected to be substantially confined

- Defined to support a fire PRA 


\section{Important Definitions}

Fire Modeling vs Fire Analysis Task: Analytical process of predicting the behavior of a fire event in terms of heat flux impinging material near the fire and behavior of those material as a result of that. Fire engineer

Zone of Influence: The area around a fire where radiative and convective heat transfer is sufficiently strong to damage equipment or cables and/or heatup other materials to the point of auto-ignition.

Fire PRA: Estimating the probability of equipment damage/failure as a result of fire and overall consequences. 


\section{Compartment Fires}

- Compartment fires are enclosure fires that are confined (at least initially) to a single compartment or space (i.e. room or hall way) within a structure.

- The course of the compartment fire and the conditions that result depend on the following major variables (others also exist):

- Fire growth time

- Heat release rate (HRR) of combustibles

- Enclosure size

- Enclosure design and construction

- Enclosure ventilation

- Suppression systems 


\section{Compartment Fires}

- Ventilation is achieved through open doors and windows and HVAC systems

- In some ventilated situations, ventilation is stopped automatically under fire conditions either through termination of HVAC system operation or shutting or closing of fire doors and dampers

- However, in other situations, ventilation may continue or unprotected opening may remain open

- These fires typically progress through 4 stages (or phases) as a function of time 


\section{Stages of Compartment Fires}

Stage 1: Fire Plume/Ceiling Jet Stage

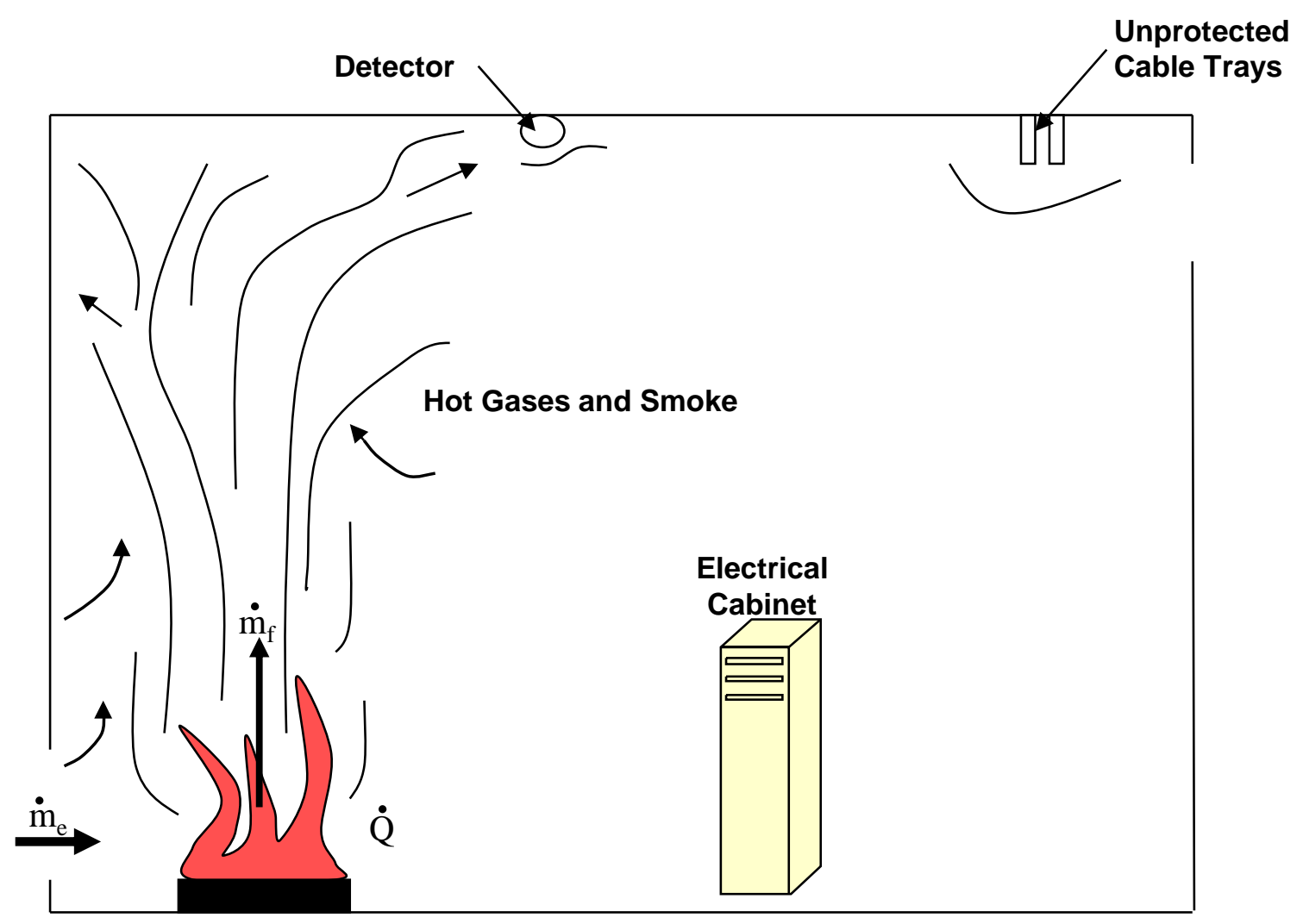

- Hot gases rise to ceiling and entrain cool air

- Decrease in plume temperature

- Increase in smoke volume

- Plume gases form a ceiling jet and continues to extend until confined by enclosure boundaries 


\section{Stages of Compartment Fires}

\section{Stage 2: Unvented Smoke Filing Stage}

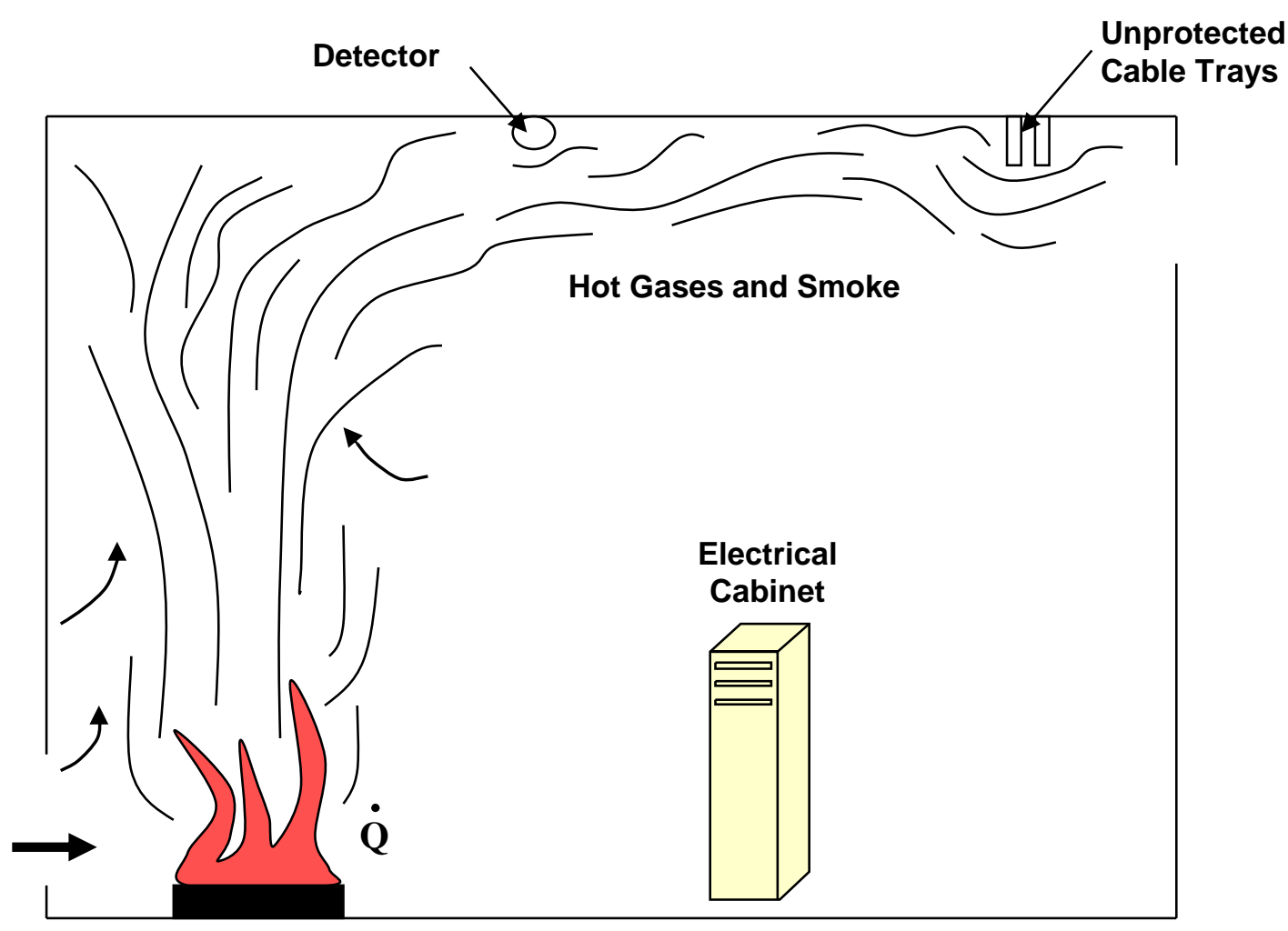

- Ceiling jet spreads to the full extent of compartment

- Smoke descends due to gas expansion

- Heat addition increase smoke layer temperature

- Continuing entrainment of cool air slows temperature increase 


\section{Stages of Compartment Fires}

\section{Stage 3: Pre-flashover Vented Stage}

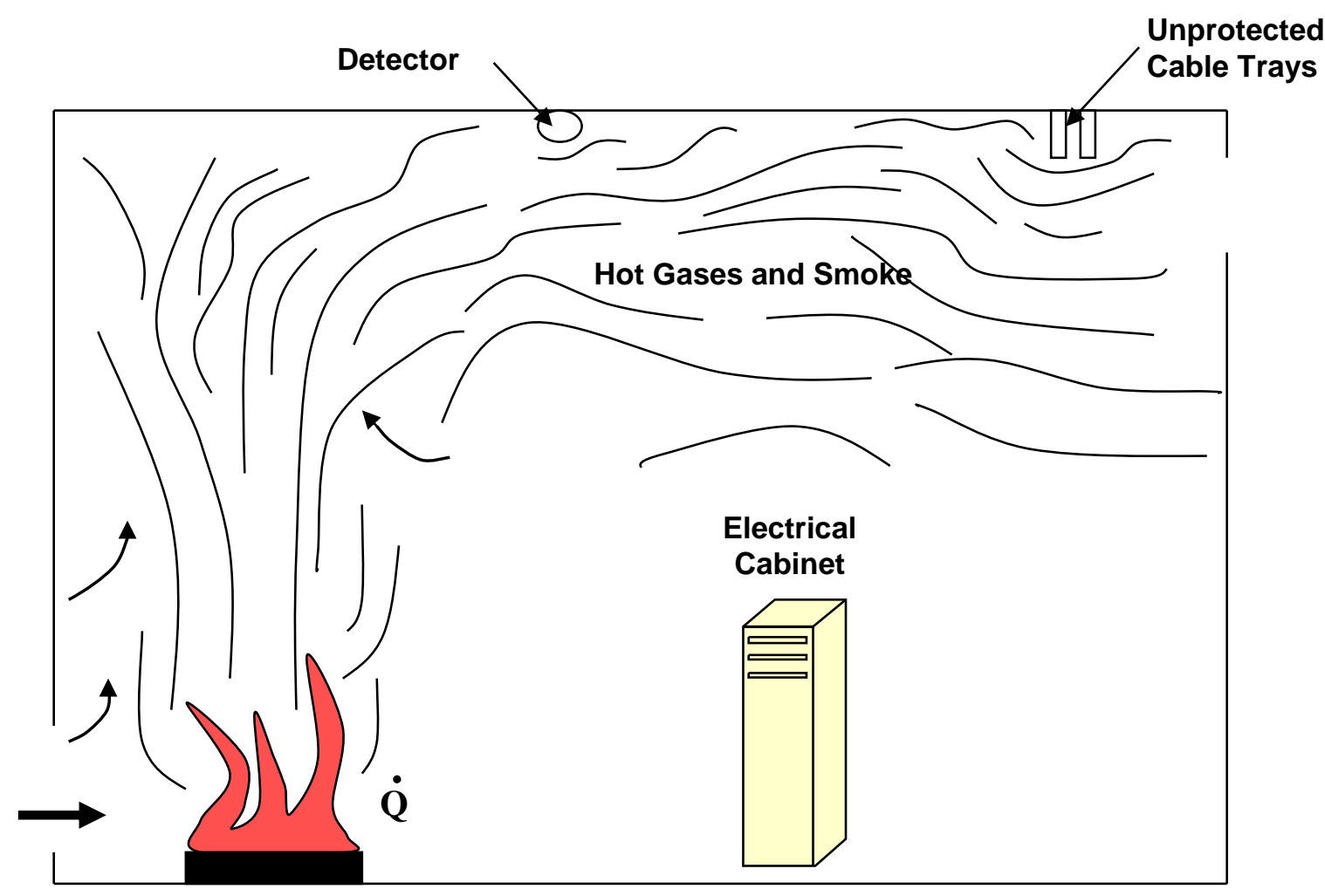

- Smoke begins to flow from the compartment

- Ventilation may occur naturally through openings (doorways)

- Ventilation may be forced by HVAC systems

- Smoke layer may continue to expand and descend 


\section{Stages of Compartment Fires}

Stage 4: Post-flashover Vented Stage

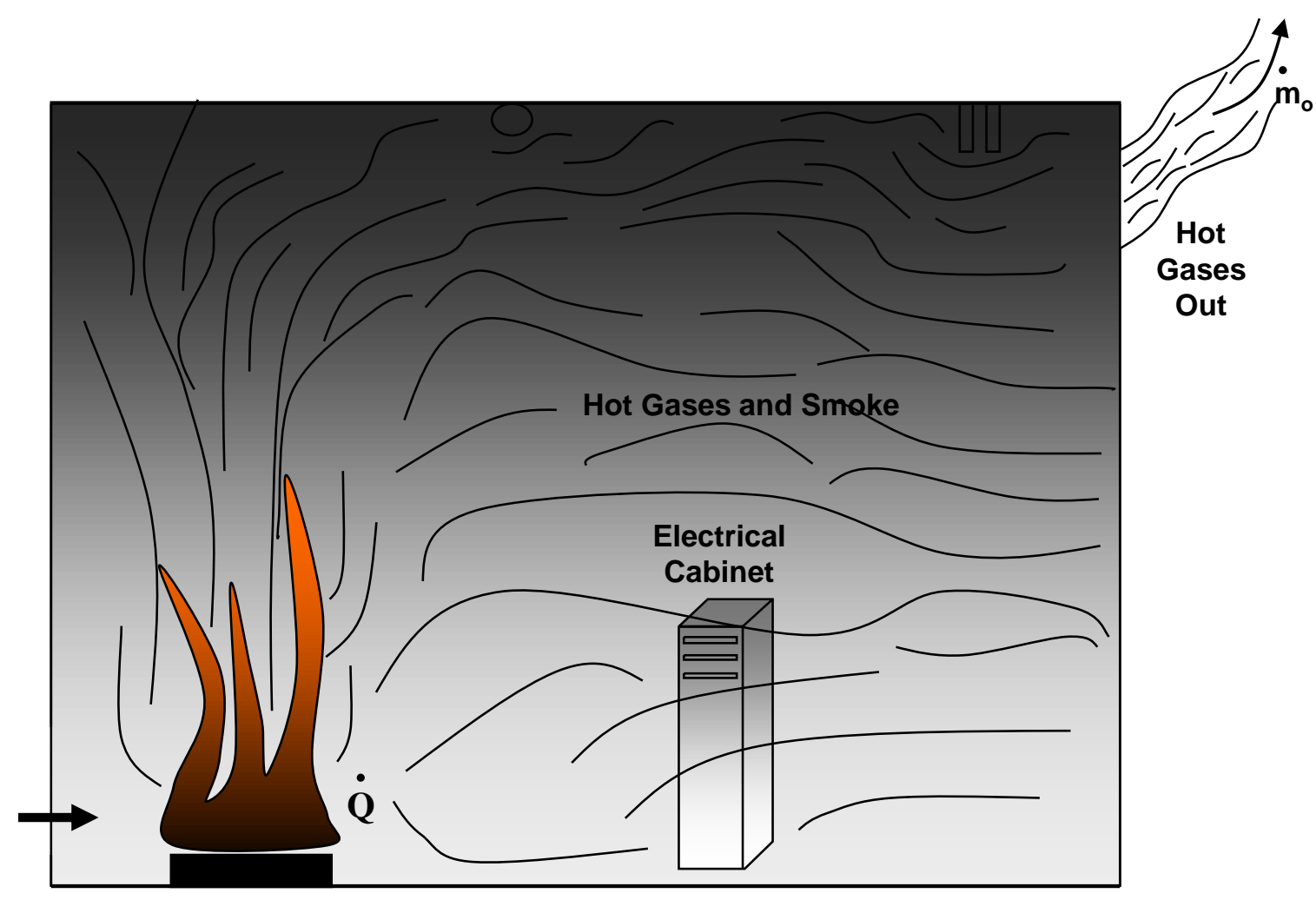

- Most significant hazard

- Thermal conditions have reached a point where all exposed combustibles ignite

- With adequate ventilation, flames may fill the enclosed volume

- Flashover causes fire to reach fully developed state where all fuel within the compartment becomes involved 


\section{Typical Features in a Compartment Fire}

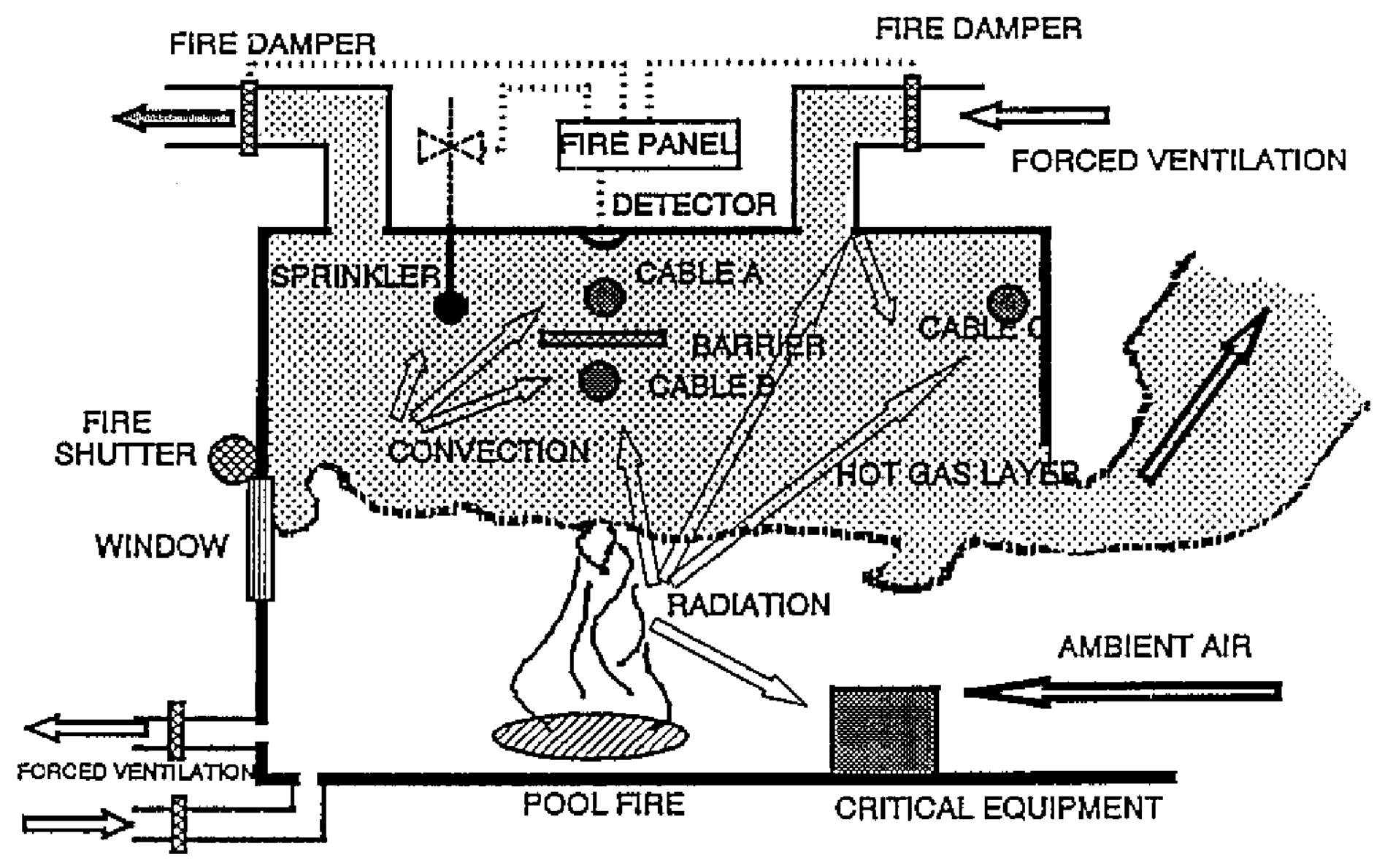




\section{Latest (Jointly Accepted) Guidance on Fire PRA}

- NUREG/CR-6850, Vol. 1 \& 2, September 2005

- Joint effort between NRC and EPRI

- Report also identified as EPRI 1011989

- Includes advances in the state-of-the-art on Fire PRA

- Talk about this in more detail later

- EPRI has recently published new interim guidance on several issues arising from pilot applications of NUREG/CR-6850

- NRC has not accepted these updates

- Joint work ongoing in Fire HRA 


\section{Acceptable Methods for Performing Internal Fire}

PRA

- The analysis should contain or involve the following:

- Identification of plant areas/locations in which a fire could impact safety-related equipment.

- Calculate a fire initiating event frequency in each area.

- Estimation of the likelihood of equipment damage by a fire in the area.

- Calculate the fire-induced core damage frequency for each area.

- Determine impact of fire on containment performance. 


\section{Major Steps of Fire Risk Analysis}

- Qualitative Analysis of Spatial Interactions

- Information gathering, data collection, and plant walkthrough.

- Plant fire locations definitions.

- Development of fire location characteristics tables.

- Development of location-based fire scenarios.

- Scenario Screening Analysis

- Qualitative screening.

- Quantitative screening. 


\section{Major Steps of Fire Risk Analysis (continued)}

- Detailed Scenario Analysis

- Information review and plant walkthrough

- For each compartment/scenario not screened

- Evaluation of scenario frequency refinement factors.

- Analysis of plant response.

- Risk quantification and sensitivity/uncertainty analysis. 


\section{Internal Fire PRA - Two-Phase Approach}

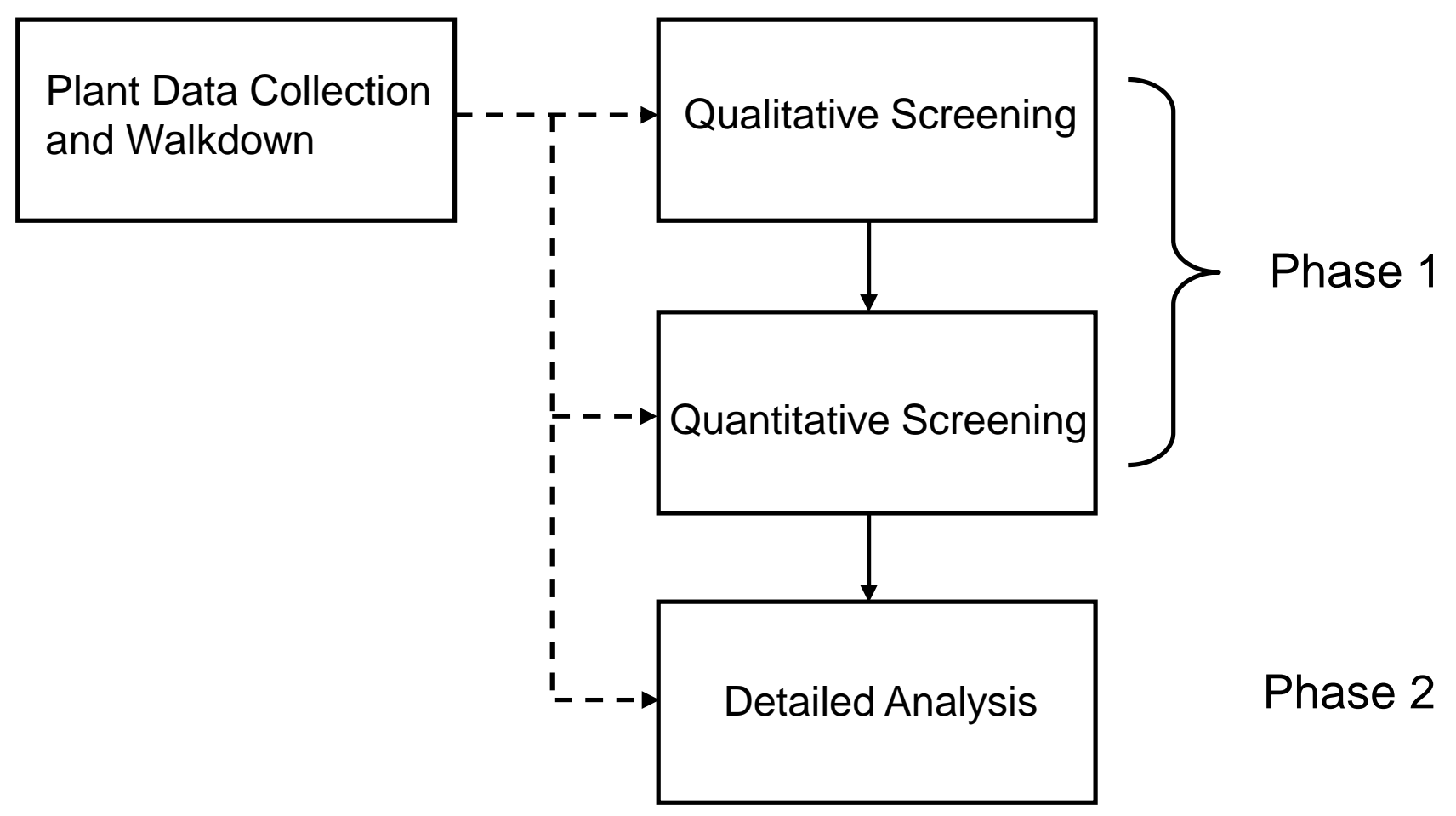




\section{Internal Fire PRA - Key Aspects}

- Phase 1 - Screening Analysis to Identify Important Fire Locations

- Screen out areas not risk significant.

- Phase 2 - Detailed Analysis of the Important Fire Scenarios

- Involves analysis of fire frequencies and performance evaluation of fire scenarios (propagation, damage, and suppression).

- Phenomenological models (COMPBRN, CFDs, etc.) for fire growth.

- Reliability and/or state-transition models for suppression.

- Uses logic models developed for Internal Events PRAs. 


\section{Overview of an Internal Fire PRA Approach}

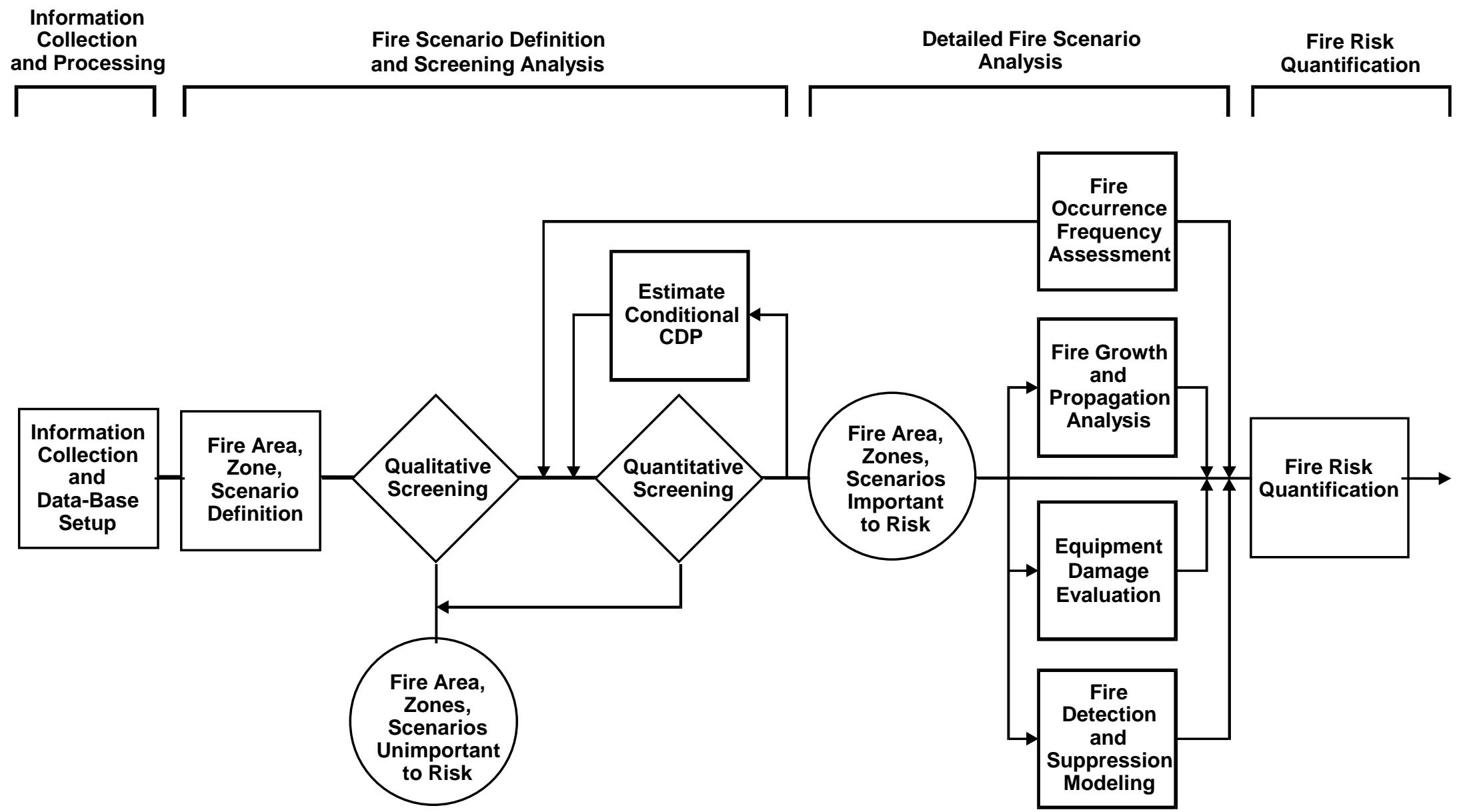




\section{Fire Risk Quantification}

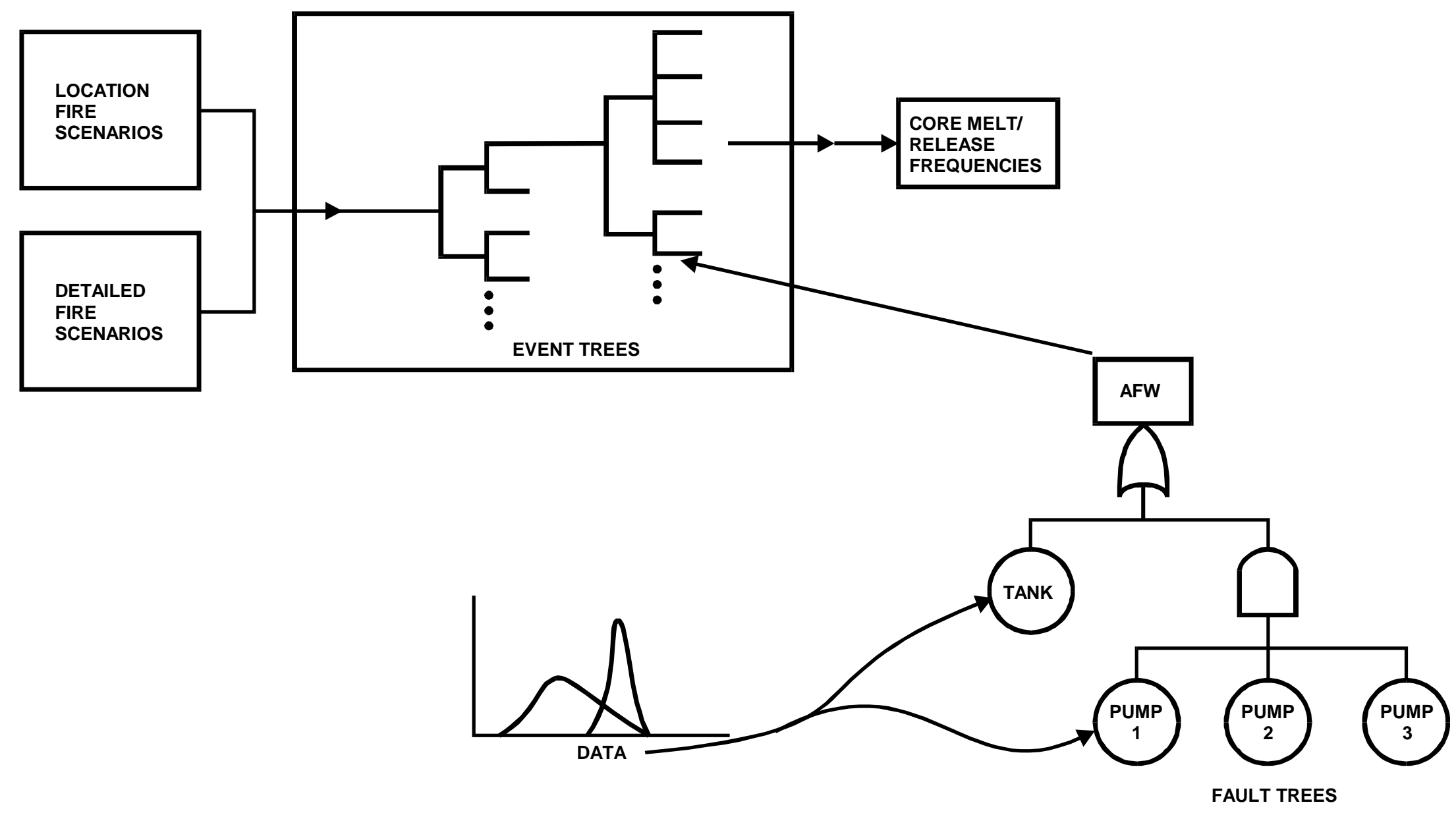




\section{Detailed Fire Scenarios}

Example types of fire scenarios (fire source and fire targets):

- Equipment fire affecting other equipment

- Raceway fire affecting other raceways

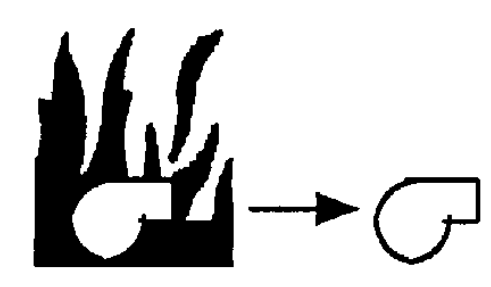

- Equipment fire affecting raceways
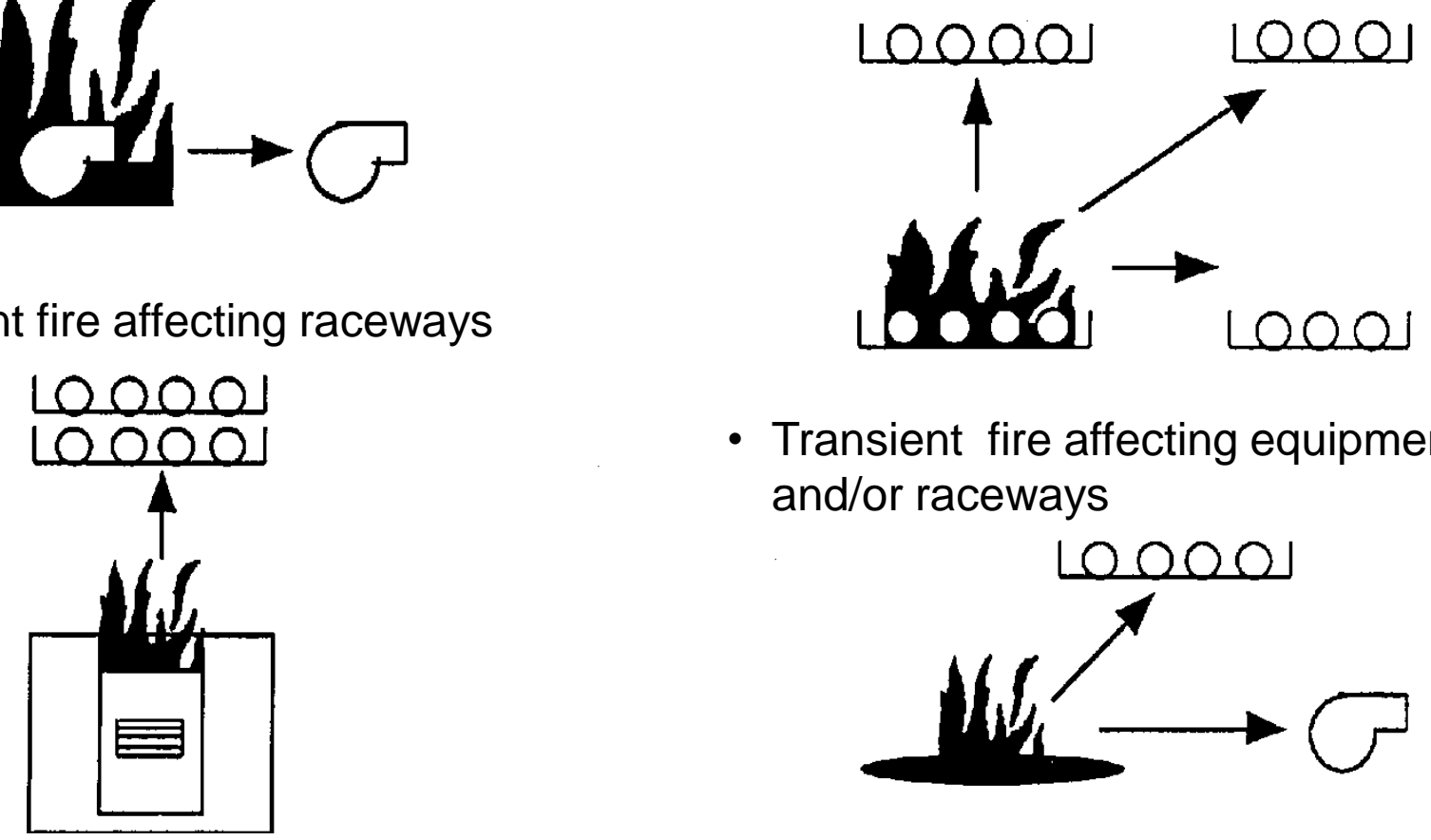

- Transient fire affecting equipment and/or raceways

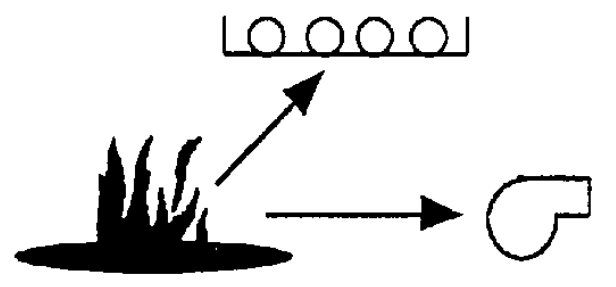




\section{Fire Occurrence Frequency Assessment}

- Determine the fire frequency for each fire location/scenario; fire initiating event frequency.

- Two approaches in fire occurrence frequency assessment:

- Location based: auxiliary building, turbine building, diesel generator building, etc.

- Component based: Battery, pumps, cable, transformer, motors, etc. 


\section{Fire Occurrence Frequency Assessment (continued)}

- Two kinds of information needed:

- Number of fire events.

- Corresponding number of years of operating experience.

- Two steps involved in fire frequency determination for the plant fire locations/scenarios:

- Calculate the fire occurrence frequencies for the plant buildings/components.

- Apportion the fire frequencies to the fire locations/scenarios. 


\section{Location-Based Fire Occurrence Frequency}

Assessment

- Used in earlier fire PRAs.

- Fire events are categorized according to the location of occurrences regardless of fire source.

- The generic fire occurrence frequencies are updated (Bayesian) with plant specific experience. 


\section{Location-Based Fire Occurrence Frequency Assessment (continued)}

- Fire occurrence frequency for a building is then apportioned to all the fire areas/zones in the building based on the characteristics of the fire areas/zones:

- Amount of ignition sources.

- Amount of combustibles.

- The size of the fire area/zone.

- Activity level in the fire area/zone.

- Whether the fire area/zone is controlled. 


\section{Five Fire Analysis Tools}




\section{Fire Analysis Tools -}

- Fire Dynamic Tool (FDT) - NUREG/CR-1805

- Developed by NRC; Algebraic Model, Excel Spread Sheet, Screening Calculation

- Fire-Induced Vulnerability Evaluation (FIVE) - EPRI TR-100370

- Developed by EPRI; Algebraic Model, Excel Spread Sheet, Screening Calculation

- Consolidated Fire Growth And Smoke Transport (CFAST) - NIST

- Detailed Fire modeling, 2-Zone Model; Hot gas layer and cool layer, Simple geometry

- Global Analysis Model for fire into Compartments (MAGIC) - EDF

- Detailed Fire modeling, Two zones approach; Hot gas layer and cool layer, Simple geometry

- Computation Fluid Dynamics Model (FDS) - NIST

- Detailed Fire modeling in complex geometries, Complex input, run time in hours to days 


\section{Fire Analysis Tools \\ Summary of five fire models}

\begin{tabular}{|c|c|c|c|c|}
\hline $\begin{array}{c}\text { Fire Model } \\
\text { Class }\end{array}$ & Examples & Typical Applications & Advantages & Disadvantages \\
\hline $\begin{array}{l}\text { Algebraic } \\
\text { models }\end{array}$ & $\begin{array}{l}\text { FDTS } \\
\text { FIVE- } \\
\text { Rev1 }\end{array}$ & $\begin{array}{l}\text { Screening calculations; } \\
\text { ZOl; target damage by } \\
\text { thermal radiation, HGL, or } \\
\text { thermal plume acting in } \\
\text { isolation. }\end{array}$ & $\begin{array}{l}\text { Simple to use; minimal } \\
\text { inputs; quick results; ability } \\
\text { to perform multiple } \\
\text { parameter sensitivity } \\
\text { studies. }\end{array}$ & $\begin{array}{l}\text { Limited application } \\
\text { range; treats } \\
\text { phenomena in isolation; } \\
\text { typically applicable only } \\
\text { to steady state or simply } \\
\text { defined transient fires } \\
\text { (e.g., proportional to the } \\
\text { square of time or } t^{2} \\
\text { fires). }\end{array}$ \\
\hline Zone Model & $\begin{array}{l}\text { CFAST } \\
\text { MAGIC }\end{array}$ & $\begin{array}{l}\text { Detailed fire modeling in } \\
\text { simple geometries; often } \\
\text { used to compute HGL } \\
\text { temperatures and target } \\
\text { heat fluxes. }\end{array}$ & $\begin{array}{l}\text { Simple to use; couples HGL } \\
\text { and localized effects; quick } \\
\text { results; ability to perform } \\
\text { multiple parameter } \\
\text { sensitivity studies. }\end{array}$ & $\begin{array}{l}\text { Error increases with } \\
\text { increasing deviation } \\
\text { from a rectangular } \\
\text { enclosure; large } \\
\text { horizontal flow paths } \\
\text { not well treated. }\end{array}$ \\
\hline $\begin{array}{l}\text { Computation Fluid } \\
\text { Dynamics Model }\end{array}$ & FDS & $\begin{array}{l}\text { Detailed fire modeling in } \\
\text { complex geometries, } \\
\text { including computing time to } \\
\text { target damage and } \\
\text { habitability (main control } \\
\text { room (MCR) abandonment } \\
\text { or manual action feasibility). }\end{array}$ & $\begin{array}{l}\text { Ability to simulate fire } \\
\text { conditions in complex } \\
\text { geometries and with } \\
\text { complex vent conditions. }\end{array}$ & $\begin{array}{l}\text { Significant effort to } \\
\text { create input files and } \\
\text { post- process the } \\
\text { results; long simulation } \\
\text { times; difficult to model } \\
\text { curved geometry, } \\
\text { smoke detector } \\
\text { performance, and } \\
\text { conditions after } \\
\text { sprinkler actuation. }\end{array}$ \\
\hline
\end{tabular}




\section{Fire Analysis Tools Summary of FDT Modules}

\begin{tabular}{|c|c|c|}
\hline $\begin{array}{c}\text { FDT }^{\mathrm{S}} \\
\text { Spreadsheet } \\
\text { Function Name }\end{array}$ & $\begin{array}{l}\text { NUREG-1805 Chapter } \\
\text { and Function Description }\end{array}$ & $\begin{array}{l}\text { NUREG-1824 } \\
\text { Verification } \\
\text { and Validation } \\
\text { Status }\end{array}$ \\
\hline 02.1_Temperature_NV.xls & $\begin{array}{l}\text { Chapter 2. Predicting Hot Gas Layer Temperature and } \\
\text { Smoke Layer Height in a Compartment Fire with Natural } \\
\text { Ventilation (Compartment with Thermally Thick/Thin } \\
\text { Boundaries): Method of McCaffrey, Quintiere, and } \\
\text { Harkleroad (MQH) }\end{array}$ & V\&V provided \\
\hline 02.2_Temperature_FV.xls & $\begin{array}{l}\text { Chapter 2. Predicting Hot Gas Layer Temperature in a } \\
\text { Compartment Fire with Forced Ventilation (Compartment } \\
\text { with Thermally Thick/Thin Boundaries): Method of Foote, } \\
\text { Pagni, and Alvares (FPA) and Method of Deal and Beyler }\end{array}$ & V\&V provided \\
\hline 02.3_Temperature_CC.xls & $\begin{array}{l}\text { Chapter 2. Predicting Hot Gas Layer Temperature in a } \\
\text { Compartment Fire with Door Closed (Compartment has } \\
\text { Sufficient Leaks to Prevent Pressure Buildup; leakage is } \\
\text { lgnored): Method of Beyler }\end{array}$ & V\&V provided \\
\hline $\begin{array}{l}\text { 03_HRR_Flame_Height_- } \\
\text { Burning_Duration_Calculation. } \\
\text { xls }\end{array}$ & $\begin{array}{l}\text { Chapter 3. Estimating Burning Characteristics of Liquid } \\
\text { Pool Fire, HRR, Burning Duration, and Flame Height }\end{array}$ & $\begin{array}{l}V \& V \text { provided for } \\
\text { flame height only }\end{array}$ \\
\hline $\begin{array}{l}\text { 04_Flame_Height_Calculations. } \\
\text { xls }\end{array}$ & $\begin{array}{l}\text { Chapter 4. Estimating Wall Fire Flame Height, Line Fire } \\
\text { Flame Height Against the Wall, and Corner Fire Flame } \\
\text { Height }\end{array}$ & V\&V not provided \\
\hline $\begin{array}{l}\text { 05.1_Heat_Flux_Calculations_ } \\
\text { Wind_Free.xls }\end{array}$ & $\begin{array}{l}\text { Chapter 5. Estimating Radiant Heat Flux from Fire to } \\
\text { aTarget Fuel (Wind-Free Condition):Point Source } \\
\text { Radiation Model (Target at Ground Level); Solid Flame } \\
\text { Radiation Model (Target at Ground Level); and Solid } \\
\text { Flame Radiation Model (Target Above Ground Level) } \\
\end{array}$ & $\begin{array}{l}\text { V\&V provided for } \\
\text { the point source } \\
\text { model and the solid } \\
\text { flame radiation } \\
\text { model(above }\end{array}$ \\
\hline $\begin{array}{l}\text { 05.2_Heat_Flux_Calculations__ } \\
\text { Wind.xls }\end{array}$ & $\begin{array}{l}\text { Chapter 5. Estimating Radiant Heat Flux from Fire to a } \\
\text { Target Fuel (Presence of Wind): Solid Flame Radiation } \\
\text { Model (Target at Ground Level); and Solid Flame } \\
\text { Radiation Model (Target Above Ground Level) }\end{array}$ & V\&V not provided \\
\hline
\end{tabular}




\section{Fire Analysis Tools Summary of FDT Modules (Continued)}

\begin{tabular}{|c|c|c|}
\hline $\begin{array}{l}\text { FDT }^{\mathrm{s}} \\
\text { Spreadsheet } \\
\text { Function Name }\end{array}$ & $\begin{array}{l}\text { NUREG-1805 Chapter } \\
\text { and Function Description }\end{array}$ & $\begin{array}{l}\text { NUREG-1824 } \\
\text { Verification } \\
\text { and Validation } \\
\text { Status }\end{array}$ \\
\hline $\begin{array}{l}\text { 05.3_Thermal_Radiation_From__ } \\
\text { Hydrocarbon_Fireballs.xls }\end{array}$ & $\begin{array}{l}\text { Chapter 5. Estimating Radiant Heat Flux from Fire to a } \\
\text { Target Fuel: Estimating Thermal Radiation from } \\
\text { Hydrocarbon Fireballs }\end{array}$ & V\&V not provided \\
\hline $\begin{array}{l}\text { 06_Ignition_Time_Calculations. } \\
\text { xls }\end{array}$ & $\begin{array}{l}\text { Chapter 6. Estimating the Ignition Time of a Target Fuel } \\
\text { Exposed to a Constant Radiative Heat Flux Method of } \\
\text { Estimating Piloted Ignition Time of Solid Materials Under } \\
\text { Radiant Exposures Method of:(1) Mikkola and } \\
\text { Wichman;(2) Quintiere and Harkleroad; (3) Janssens;(4) } \\
\text { Method of Toal, Silcock, and Shields; and(5) Method of } \\
\text { Tewarson }\end{array}$ & V\&V not provided \\
\hline $\begin{array}{l}07 \text { Cable_HRR_- } \\
\text { Calculations.xls }\end{array}$ & $\begin{array}{l}\text { Chapter 7. Estimating Full-Scale Heat Release Rate of } \\
\text { a Cable Tray Fire }\end{array}$ & V\&V not provided \\
\hline 08_Burning_Duration_Soild.xls & $\begin{array}{l}\text { Chapter 8. Estimating Burning Duration of Solid } \\
\text { Combustibles }\end{array}$ & V\&V not provided \\
\hline $\begin{array}{l}\text { 09_Plume_Temperature_- } \\
\text { Calculations.xls }\end{array}$ & $\begin{array}{l}\text { Chapter 9. Estimating Centerline Temperature of a } \\
\text { Buoyant Fire Plume }\end{array}$ & V\&V provided \\
\hline $\begin{array}{l}\text { 10_Detector_Activation_ } \\
\text { Time.xls }\end{array}$ & $\begin{array}{l}\text { Estimating Detector Response Times: Chapter } \mathbf{1 0 .} \\
\text { Estimating Sprinkler Response Time Chapter } \mathbf{1 1 .} \\
\text { Estimating Smoke Detector Response Time Chapter } 12 . \\
\text { Estimating Heat Detector Response Time }\end{array}$ & V\&V not provided \\
\hline $\begin{array}{l}\text { 13_Compartment_Flashover_ } \\
\text { Calculations.xls }\end{array}$ & $\begin{array}{l}\text { Chapter 13. Predicting Compartment Flashover } \\
\text { Compartment Post-Flashover Temperature: Method of } \\
\text { Law Minimum Heat Release Rate Required to } \\
\text { Compartment Flashover:(1) Method of McCaffrey, } \\
\text { Quintiere, and Harkleroad(MQH);(2) Method of } \\
\text { Babrauskas; and(3) Method of Thomas }\end{array}$ & V\&V not provided \\
\hline $\begin{array}{l}\text { 14_Compartment_Over_ } \\
\text { Pressure_Calculations.xls }\end{array}$ & $\begin{array}{l}\text { Chapter 14. Estimating Pressure Rise Attributable to a } \\
\text { Fire in a Closed Compartment }\end{array}$ & V\&V not provided \\
\hline
\end{tabular}




\section{Fire Analysis Tools Summary of FDT Modules (Continued)}

\begin{tabular}{|c|c|c|}
\hline $\begin{array}{l}\text { FDT }^{\text {S }} \\
\text { Spreadsheet } \\
\text { Function Name }\end{array}$ & $\begin{array}{l}\text { NUREG-1805 Chapter } \\
\text { and Function Description }\end{array}$ & $\begin{array}{l}\text { NUREG-1824 } \\
\text { Verification } \\
\text { and Validation } \\
\text { Status }\end{array}$ \\
\hline 15_Explosion_Claculations.xls & $\begin{array}{l}\text { Chapter } 15 . \text { Estimating the Pressure Increase and } \\
\text { Explosive Energy Release Associated with Explosions }\end{array}$ & V\&V not provided \\
\hline $\begin{array}{l}\text { 16_Battery_Compartment_- } \\
\text { Flammable_Gas_Conc.xls }\end{array}$ & $\begin{array}{l}\text { Chapter 16. Calculating the Rate of Hydrogen } \\
\text { GasGeneration in Battery Compartments: } \\
\text { Method of Estimating Hydrogen Gas Generation } \\
\text { Rate in Battery Compartments; Method of } \\
\text { Estimating Flammable Gas and Vapor } \\
\text { Concentration Buildup in Enclosed Spaces; and } \\
\text { Method of Estimating Flammable Gas and Vapor } \\
\text { Concentration Buildup Time in Enclosed Spaces }\end{array}$ & V\&V not provided \\
\hline $\begin{array}{l}\text { 17.1_FR_Beams_Columns_ } \\
\text { Substitution_Correlation.xls }\end{array}$ & $\begin{array}{l}\text { Chapter 17. Calculating the Fire Resistance of Structura } \\
\text { Steel Members (Algebraic Models): Beam Substitution } \\
\text { Correlation (Spray-Applied Materials); and Column } \\
\text { Substitution Correlation (Spray-Applied Materials) }\end{array}$ & V\&V not provided \\
\hline $\begin{array}{l}\text { 17.2_FR_Beams_Columns__ } \\
\text { Quasi_Steady_State_Spray_ } \\
\text { Insulated.xls }\end{array}$ & $\begin{array}{l}\text { Chapter 17. Calculating the Fire Resistance } \\
\text { ofStructural Steel Members (Algebraic Models): Heat } \\
\text { Transfer Analysis using Numerical Methods Protected; } \\
\text { and Steel Beams and Columns (Spray-Applied) }\end{array}$ & V\&V not provided \\
\hline $\begin{array}{l}\text { 17.3_FR_Beams_Columns__ } \\
\text { Quasi_Steady_State_Board_ } \\
\text { Insulated.xls }\end{array}$ & $\begin{array}{l}\text { Chapter 17. Calculating the Fire Resistance of } \\
\text { Structural Steel Members: Heat Transfer Analysis using } \\
\text { Numerical Methods Protected Steel Beams and } \\
\text { Columns (Board Materials) }\end{array}$ & V\&V not provided \\
\hline $\begin{array}{l}\text { 17.4_FR_Beams_Columns_ } \\
\text { Quasi_Steady_State_- } \\
\text { Uninsulated.xls }\end{array}$ & $\begin{array}{l}\text { Chapter 17. Calculating the Fire Resistance of } \\
\text { Structural Steel Members: Heat Transfer Analysis using } \\
\text { Numerical Methods Unprotected Steel Beams and } \\
\text { Columns }\end{array}$ & V\&V not provided \\
\hline $\begin{array}{l}\text { 18_Visibility_Through_Smoke. } \\
\text { xls }\end{array}$ & Chapter 18. Estimating Visibility Through Smoke & V\&V not provided \\
\hline
\end{tabular}




\section{Fire Analysis Tools Summary of FIVE Modules}

\begin{tabular}{|c|c|c|}
\hline $\begin{array}{l}\text { FIVE- } \\
\text { Rev1Function }\end{array}$ & Function Description & $\begin{array}{c}\text { NUREG-1824 } \\
\text { Verification } \\
\text { and Validation } \\
\text { Status } \\
\end{array}$ \\
\hline Qf & Heat release rate profile considering $t^{2}$ growth and four stages. & V\&V not provided \\
\hline Firr & $\begin{array}{l}\text { Estimates flame irradiation at distance } r \text { from the fire source. } \\
\text { Point source approximation for REMOTE targets. }\end{array}$ & V\&V provided \\
\hline FHeight & Flame height based on Heskestad flame height correlation. & V\&V provided \\
\hline TpAlpert & $\begin{array}{l}\text { Plume temperature at a specific height based on Alpert plume } \\
\text { temperature correlation. }\end{array}$ & V\&V not provided \\
\hline TpMcCaffrey & $\begin{array}{l}\text { Plume temperature at a specific height based on McCaffrey plume } \\
\text { temperature correlation. }\end{array}$ & V\&V not provided \\
\hline TpHeskestad & $\begin{array}{l}\text { Plume temperature at a specific height based on Heskestad } \\
\text { plume temperature correlation. }\end{array}$ & V\&V not provided \\
\hline Plcflux & Estimates convective heat flux in the fire plume. & V\&V not provided \\
\hline VpAlpert & $\begin{array}{l}\text { Plume velocity at a specific height based on Alpert's plume } \\
\text { temperature correlation. }\end{array}$ & V\&V not provided \\
\hline VpMcCaffrey & $\begin{array}{l}\text { Plume velocity at a specific height based on McCaffrey plume } \\
\text { temperature correlation. }\end{array}$ & V\&V provided \\
\hline VpHeskestad & $\begin{array}{l}\text { Plume velocity at a specific height based on Heskestad plume } \\
\text { temperature correlation. }\end{array}$ & V\&V provided \\
\hline EpZukoski & $\begin{array}{l}\text { Air entrainment into plume based on Zukoski plume entrainment } \\
\text { correlation. }\end{array}$ & V\&V not provided \\
\hline EpThomas & $\begin{array}{l}\text { Air entrainment into plume based on Thomas plume entrainment } \\
\text { correlation. }\end{array}$ & V\&V not provided \\
\hline EpHeskestad & $\begin{array}{l}\text { Air entrainment into plume based on Heskestad plume } \\
\text { entrainment correlation. }\end{array}$ & V\&V not provided \\
\hline
\end{tabular}




\section{Fire Analysis Tools Summary of FIVE Modules (Continued)}

\begin{tabular}{|c|c|c|}
\hline $\begin{array}{l}\text { FIVE- } \\
\text { Rev1Function }\end{array}$ & Function Description & $\begin{array}{l}\text { NUREG-1824 } \\
\text { Verification } \\
\text { and Validation } \\
\text { Status }\end{array}$ \\
\hline PdHeskestad & Estimates plume diameter based on Heskestad plume correlation. & V\&V not provided \\
\hline TcjAlpert & $\begin{array}{l}\text { Unconfined ceiling jet temperature based on Alpert ceiling jet } \\
\text { correlation. }\end{array}$ & V\&V provided \\
\hline TcjDelichatsios & $\begin{array}{l}\text { Confined ceiling jet temperature based on Delichatsios ceiling jet } \\
\text { correlation. }\end{array}$ & V\&V not provided \\
\hline Cjcflux & Estimates convective heat flux in the ceiling jet. & V\&V not provided \\
\hline VcjAlpert & $\begin{array}{l}\text { Unconfined ceiling jet velocity based on Alpert ceiling jet } \\
\text { correlation. }\end{array}$ & V\&V not provided \\
\hline MQHTemperature & $\begin{array}{l}\text { Compartment temperature after a specified time, given a } \\
\text { steadyHRR based on } \mathrm{MQH} \text { approach. }\end{array}$ & $\mathrm{V} \& \mathrm{~V}$ provided \\
\hline MQHFlashover & $\begin{array}{l}\text { Heat release rate required for flashover after a specified time } \\
\text { based on } \mathrm{MQH} \text { approach. }\end{array}$ & V\&V not provided \\
\hline FiveTemp & Estimates compartment temperature based on FIVE-Rev1. & V\&V provided \\
\hline Detact & $\begin{array}{l}\text { Activation time of heat detection devices based on heat release } \\
\text { rate profiles. }\end{array}$ & V\&V not provided \\
\hline Aset & $\begin{array}{l}\text { Time required by Hot Gas Layer to reach a specific height based } \\
\text { on heat release rate profiles and openings at the bottom of the } \\
\text { enclosure. }\end{array}$ & V\&V not provided \\
\hline CThrr & $\begin{array}{l}\text { Estimates heat release rate from cable trays. The correlation is } \\
\text { based on } 14 \text { experiments with a stack of } 12 \text { horizontal cable trays } \\
\text { and } 2 \text { experiments with a combination of } 12 \text { horizontal cable trays } \\
\text { and } 3 \text { vertical trays. }\end{array}$ & V\&V not provided \\
\hline Visib & $\begin{array}{l}\text { Estimates the length of a visible path in a smoke environment. } \\
\text { The correlation applies to light-reflecting signs. }\end{array}$ & V\&V not provided \\
\hline Ttar & Estimates target temperature under constant heat flux. & V\&V not provided \\
\hline Ttdam & Time to target damage under constant heat flux. & V\&V not provided \\
\hline
\end{tabular}




\section{Fire Analysis Tools}

Fire modeling attributes included in NUREG 1824/EPRI 1011999 (2007)

\begin{tabular}{|l|c|c|c|c|c|}
\hline \multirow{2}{*}{\multicolumn{1}{|c|}{ Fire Modeling Attributes }} & \multicolumn{5}{c|}{ Fire Model } \\
\cline { 2 - 6 } & FDT $^{\mathbf{s}}$ & FIVE-Rev1 & CFAST & MAGIC & FDS \\
\hline Hot Gas Layer (HGL) Temperature & YES & YES & YES & YES & YES \\
\hline Hot Gas Layer (HGL) Height & NO & NO & YES & YES & YES \\
\hline Ceiling Jet Temperature & NO & YES & YES & YES & YES \\
\hline Plume Temperature & YES & YES & NO & YES & YES \\
\hline Flame Height & YES & YES & YES & YES & YES \\
\hline Radiated Heat Flux to Targets & YES & YES & YES & YES & YES \\
\hline Total Heat Flux to Targets & NO & NO & YES & YES & YES \\
\hline Total Heat Flux to Walls & NO & NO & YES & YES & YES \\
\hline Wall Temperature & NO & NO & YES & YES & YES \\
\hline Target Temperature & NO & NO & YES & YES & YES \\
\hline Smoke Concentration & NO & NO & YES & YES & YES \\
\hline Oxygen Concentration & NO & NO & YES & YES & YES \\
\hline Room Pressure & NO & NO & YES & YES & YES \\
\hline
\end{tabular}




\section{Fire Frequency Bins and Generic Frequencies}




\section{Plant Generic Locations}

Eight Plant Generic Locations and Thirty Seven Fire Frequency Bins Plant Generic Locations

- Battery Room

- Containment (PWR)

- Control Room

- Control/Auxiliary/Reactor Building

- Diesel Generator Room

- Plant-Wide Components

- Transformer Yard

- Turbine Building 


\section{Fires in LWRs (NUREG/CR-6850)}

Table 6-1

Fire Frequency Bins and Generic Frequencies (Continued)

\begin{tabular}{|c|c|c|c|c|c|c|c|c|c|c|}
\hline \multirow{2}{*}{ ID } & \multirow{2}{*}{ Location } & \multirow{2}{*}{$\begin{array}{l}\text { Ignition Source } \\
\text { (Equipment Type) }\end{array}$} & \multirow{2}{*}{ Mode } & \multirow{2}{*}{$\begin{array}{c}\text { Generic } \\
\text { Freq } \\
\text { (per rx yr) }\end{array}$} & \multicolumn{6}{|c|}{ Split Fractions for Fire Type } \\
\hline & & & & & Electrical & Oil & Transient & Hotwork & Hydrogen & HEAF $^{\prime}$ \\
\hline 25 & \begin{tabular}{|l|} 
Plant-Wide \\
Components
\end{tabular} & Transients & Power & $9.9 \mathrm{E}-03$ & 0 & 0 & 1.0 & 0 & 0 & 0 \\
\hline 26 & $\begin{array}{l}\text { Plant-Wide } \\
\text { Components }\end{array}$ & Ventilation Subsystems & All & $7.4 \mathrm{E}-03$ & 0.95 & 0.05 & 0 & 0 & 0 & 0 \\
\hline 27 & Transformer Yard & Transformer-Catastrophic ${ }^{2}$ & Power & $6.0 \mathrm{E}-03$ & \multicolumn{2}{|l|}{$1.0^{3}$} & 0 & 0 & 0 & 0 \\
\hline 28 & Transformer Yard & Transformer - Non Catastrophic $^{2}$ & Power & $1.2 \mathrm{E}-02$ & \multicolumn{2}{|l|}{$1.0^{3}$} & 0 & 0 & 0 & 0 \\
\hline 29 & Transformer Yard & Yard transformers (Others) & Power & $2.2 \mathrm{E}-03$ & 1.0 & 0 & 0 & 0 & 0 & 0 \\
\hline 30 & Turbine Building & Boiler & All & $1.1 \mathrm{E}-03$ & 0 & 1.0 & 0 & 0 & 0 & 0 \\
\hline 31 & Turbine Building & $\begin{array}{l}\text { Cable fires caused by welding } \\
\text { and cutting }\end{array}$ & Power & $1.6 \mathrm{E}-03$ & 0 & 0 & 0 & 1.0 & 0 & 0 \\
\hline 32 & Turbine Building & Main Feedwater Pumps & Power & $1.3 \mathrm{E}-02$ & 0.11 & 0.89 & 0 & 0 & 0 & 0 \\
\hline 33 & Turbine Building & Turbine Generator Excitor & Power & $3.9 \mathrm{E}-03$ & 1.0 & 0 & 0 & 0 & 0 & 0 \\
\hline 34 & Turbine Building & Turbine Generator Hydrogen & Power & $6.5 \mathrm{E}-03$ & 0 & 0 & 0 & 0 & 1.0 & 0 \\
\hline 35 & Turbine Building & Turbine Generator Oil & Power & $9.5 \mathrm{E}-03$ & 0 & 1.0 & 0 & 0 & 0 & 0 \\
\hline 36 & Turbine Building & $\begin{array}{l}\text { Transient fires caused by welding } \\
\text { and cutting }\end{array}$ & Power & $8.2 \mathrm{E}-03$ & 0 & 0 & 0 & 1.0 & 0 & 0 \\
\hline 37 & Turbine Building & Transients & Power & $8.5 \mathrm{E}-03$ & 0 & 0 & 1.0 & 0 & 0 & 0 \\
\hline
\end{tabular}

1. See Appendix M for a description of high-energy arcing fault (HEAF) fires.

2. See Section 6.5 .6 below for a definition.

3. The event should be considered either as an electrical or oil fire, whichever yields the worst consequences. 


\section{Fire Initiating Event Frequencies (/yr)*}

\begin{tabular}{|c|c|c|c|c|}
\hline Fire Area & Mean & $\begin{array}{c}5 \text { th } \\
\text { Percentile }\end{array}$ & $\begin{array}{l}50 \text { th } \\
\text { Percentile }\end{array}$ & $\begin{array}{c}95 \text { th } \\
\text { Percentile }\end{array}$ \\
\hline Control Room & $1.8 \mathrm{E}-3$ & $1.2 \mathrm{E}-6$ & $9.6 E-4$ & $7.4 \mathrm{E}-3$ \\
\hline Cable Vault/Tunnel & $7.5 \mathrm{E}-3$ & $3.0 \mathrm{E}-6$ & $1.8 \mathrm{E}-3$ & $1.6 \mathrm{E}-2$ \\
\hline $\begin{array}{l}\text { Electrical Switchgear } \\
\text { Room }\end{array}$ & $8.0 \mathrm{E}-3$ & $2.0 E-5$ & $2.4 \mathrm{E}-3$ & $1.7 \mathrm{E}-2$ \\
\hline Auxiliary Building & $6.6 \mathrm{E}-2$ & $2.7 \mathrm{E}-2$ & $5.9 E-2$ & $1.6 \mathrm{E}-1$ \\
\hline Pump Room & $3.7 E-3$ & \multicolumn{3}{|c|}{ (Lognormal EF $=3$ ) } \\
\hline
\end{tabular}

*[NUREG/CR-4550, Vol. 3, Part 3] 


\section{Component-Based Fire Occurrence Frequency}

Assessment

- Fire frequency in a compartment is proportional to the number of potential ignition sources.

- Used in more recent fire PRAs.

- Fire events are categorized according to the component types.

- The generic fire occurrence frequencies are updated (Bayesian) with plant-specific experience.

- Fire occurrence frequency for a fire area/zone in the plant is based on the amount and type of fire ignition sources in that fire area/zone. 


\section{Example of Component- Based Fire Occurrence Frequencies from NUREG/CR-6144}




\section{Example - Fire Frequency from Bayesian Updating for Selected Component Categories ${ }^{+}$}

Type of Fire (fire area)

MCC Small

MCC Large

Bus Small

Bus Large

Bus Small,

Shutdown Only

Transformer Small

Transformer Large

Pump Small

Pump Small,

Shutdown Only

UPS, Shutdown Only

\begin{tabular}{|c|c|c|c|}
\hline $5 \%$ & $50 \%$ & Mean & $95 \%$ \\
\hline $1.85-3$ & $5.34-3$ & $6.56-3$ & $1.54-2$ \\
\hline $4.0-5$ & $2.9-4$ & $6.2-4$ & $2.2-3$ \\
\hline $1.5-4$ & $1.4-3$ & $3.4-3$ & $1.2-2$ \\
\hline $8.8-5$ & $6.2-4$ & $1.3-3$ & $4.4-3$ \\
\hline $1.1-4$ & $8.2-4$ & $1.8-3$ & $63-3$ \\
\hline $5.5-4$ & $2.1-3$ & $2.9-3$ & $8.1-3$ \\
\hline $2.9-4$ & $1.4-3$ & $2.2-3$ & $6.6-3$ \\
\hline $2.4-5$ & $2.9-4$ & $9.4-4$ & $3.6-3$ \\
\hline $1.9-3$ & $6.1-3$ & $7.9-3$ & $2.0-2$ \\
\hline $1.13-4$ & $8.3-4$ & $1.7-3$ & $6.1-3$ \\
\hline
\end{tabular}




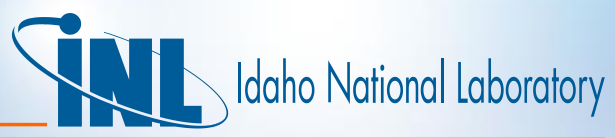

\section{Example - Fire Frequency from Bayesian Updating for Selected Component Categories ${ }^{+}$}

\begin{tabular}{|l|c|c|c|c|}
\hline $\begin{array}{l}\text { Type of Fire } \\
\text { (fire area) }\end{array}$ & $5 \%$ & $50 \%$ & Mean & $95 \%$ \\
\hline Relay Small & $1.1-3$ & $3.1-3$ & $9.3-3$ & $3.9-3$ \\
\hline Relay Medium & $3.9-5$ & $2.9-4$ & $6.2-4$ & $2.2-3$ \\
\hline $\begin{array}{l}\text { Relay Small, } \\
\text { Shutdown Only }\end{array}$ & $1.6-3$ & $5.0-3$ & $6.4-3$ & $1.6-2$ \\
\hline $\begin{array}{l}\text { Large, Large } \\
\text { Switchgear }\end{array}$ & $4.9-7$ & $2.9-6$ & $5.2-6$ & $1.7-5$ \\
\hline Cable, Self-Ignited & $1.8-4$ & $1.4-3$ & $2.9-3$ & $1.0-2$ \\
\hline Transients (CT/RB) & $1.5-4$ & $1.2-3$ & $2.4-3$ & $8.7-3$ \\
\hline Transients (TB) & $8.4-5$ & $6.1-4$ & $1.3-3$ & $4.5-3$ \\
\hline Transients (SWGR) & $9.2-5$ & $6.4-4$ & $1.3-3$ & $4.4-3$ \\
\hline $\begin{array}{l}\text { Transients, Shutdown } \\
\text { Only (CT/RB) }\end{array}$ & $2.6-3$ & $9.8-3$ & $1.4-2$ & $3.7-2$ \\
\hline $\begin{array}{l}\text { Transients, Shutdown } \\
\text { Only (TB) }\end{array}$ & $1.1-4$ & $8.3-4$ & $1.7-3$ & $6.2-3$ \\
\hline $\begin{array}{l}\text { Transients, Shutdown } \\
\text { Only (SWGR) }\end{array}$ & $1.9-4$ & $1.6-3$ & $3.8-3$ & $1.4-2$ \\
\hline
\end{tabular}

+ NOTE: All fire frequencies are per plant year, not per panel year or cabinet year, similarly for pumps. 


\section{Fire Growth and Propagation Analysis}

- Model more realistic impact of fire on the equipment in that location.

- Consider relative location of fire source and safety-related equipment (target).

- Consider heat release rate of fire source and duration of fire exposure.

- Fire growth rate and size depend on amount/type of combustible and ventilation.

- Use computer code:

- To predict time to damage of cable trays.

- To determine critical distance of fire source from target.

- Computer codes: COMPBRN IIle, CFAST, FASTLITE, FPETOOL, FLAMME-S, MAGIC, CFD models, etc. 


\section{Example of COMPBRN IIle Analysis Results from NUREG/CR-6144}




\section{Cable Damage Time for Oil Fires in ESGR Room $J$ (Time in Minutes)}

\begin{tabular}{|c|c|c|c|c|c|c|c|c|c|c|}
\hline \multirow{3}{*}{$\begin{array}{c}\text { Cable } \\
\text { Elevation } \\
\text { ft. }\end{array}$} & \multicolumn{10}{|c|}{ Fire Source Distance from Cable, Ft. } \\
\hline & \multicolumn{2}{|c|}{ Small Fire } & \multicolumn{2}{|c|}{ Medium Fire } & \multicolumn{6}{|c|}{ Large Fire } \\
\hline & 1 & 2 & 2 & 3 & 0 & 2 & 3 & 4 & 4.5 & 5 \\
\hline 7 & 2 & - & 2 & - & l & 2 & 3 & 5 & 10 & - \\
\hline 9 & 3 & - & 3 & - & 1 & 2 & 3 & 7 & - & - \\
\hline 10 & 3 & - & 5 & - & 1 & 2 & 4 & - & - & - \\
\hline 11 & 3 & - & 8 & - & 1 & 2 & 5 & - & - & - \\
\hline 11.5 & - & $\cdot$ & - & - & 1 & 2 & 5 & - & - & . \\
\hline 12.5 & - & - & - & - & - & 4 & 9 & - & - & - \\
\hline 13.5 & - & - & - & - & 3 & 4 & - & - & - & - \\
\hline
\end{tabular}

Note: 1. Cable at $7 \mathrm{ft}$. is non-critical

2. - No damage predicted

3. Cable ignition is predicted for large fires at 0 and $2 \mathrm{ft}$. from the cable tray. 


\section{Component Fragilities and Failure Modes Evaluation}

- Assess equipment response and determine the likelihood and mode of equipment failure.

- Fire in a fire zone assumed to damage equipment, e.g.,

- Cable assumed damaged if surface temperature greater than damage temperature;

- Some other components may be assumed damaged if incident heat flux exceeds a critical value.

- Evaluate equipment failure mode; fire damage may not disable fail-safe equipment.

- Impact of fire on control cables and circuits; loss of function, spurious actuation. 


\section{Fire-Induced Cable Failures}

- Fire-induced failures of electrical cables

- Electrical insulation capability of the insulation material degrades as the cables are heated by fire.

- All cable insulation and jacket materials support combustion.

- One of the most important contributors to fire risk.

- Risk-important areas in the plant

- Presence of significant fire ignition sources in the compartments.

- Compartments through which critical electrical cables are routed.

- Cost of tracing cables can be significant fraction of overall fire PRA cost 


\section{Cable Insulation Materials}

- Two broad categories: Thermoset and thermoplastic

- Thermoplastic

- Easy to manufacture and economical to use

- Generally NOT qualified (IEEE 383), more prone to fail (melting and burning)

- Polyethylene (PE), Polyvinyl chloride (PVC), polyurethane, polypropylene (PPE), nylon, Teflon, etc.

- Thermoset

- Generally qualified

- Ethylene propylene rubber (EPR), crosslinked polyethylene (XLPE), DuPont's Hypalon, neoprene, silicone rubber, etc. 


\section{Cables insulation/jacket types}

- Thermoplastic

- Melt if heated, solidify if cooled,

- Drip and burn as a liquid pool

- More wimpy

- Examples:

- Polyethylene (PE)

- Polyvinylchloride (PVC)

- Generally not qualified
- Thermoset

- Don't melt

- Burn/char in place if heated enough

- More macho

- Examples:

- Cross-linked polyethylene (XLPE or XPE)

- Ethylene-Propylene rubber (EPR)

- Generally qualified 


\section{Damage Thresholds}

Screening Criteria for Assessment of Ignition and Damage Potential of Electrical Cables

Cable Type: Thermoplastic

Heat flux

Temperature

Cable type: Thermoset

Heat flux

Temperature
(Metric)

$6 \mathrm{~kW} / \mathrm{m}^{2}$

$205^{\circ} \mathrm{C}$

(Metric)

$11 \mathrm{~kW} / \mathrm{m}^{2}$

$330^{\circ} \mathrm{C}$
(English)

$0.5 \mathrm{BTU} / \mathrm{ft}^{2} \mathrm{~s}$

$400^{\circ} \mathrm{F}$

(English)

1.0 BTU/ft ${ }^{2} \mathrm{~s}$

$625^{\circ} \mathrm{F}$ 


\section{Damage Time Look-Up Table (Example*)}

\section{*Table A7.1 from IMC 0609, Appendix F, Attachment 7, 02/28/05}

\begin{tabular}{|c|c|c|}
\hline \multicolumn{3}{|c|}{ Table A7.1 - Failure Time-Temperature Relationship for Thermoset Cables } \\
\hline \multicolumn{2}{|c|}{ Exposure Temperature } & $\begin{array}{c}\text { Time to Failure } \\
\text { (minutes) }\end{array}$ \\
\hline${ }^{\circ} \mathrm{C}$ & ${ }^{\circ} \mathrm{F}$ & 28 \\
\hline $330 \leq \mathrm{T}<335$ & $625 \leq \mathrm{T}<634$ & 24 \\
\hline $335 \leq \mathrm{T}<340$ & $634 \leq \mathrm{T}<642$ & 20 \\
\hline $340 \leq \mathrm{T}<345$ & $642 \leq \mathrm{T}<651$ & 16 \\
\hline $345 \leq \mathrm{T}<350$ & $651 \leq \mathrm{T}<660$ & 13 \\
\hline $350 \leq \mathrm{T}<360$ & $660 \leq \mathrm{T}<680$ & 10 \\
\hline $360 \leq \mathrm{T}<370$ & $680 \leq \mathrm{T}<700$ & 9 \\
\hline $370 \leq \mathrm{T}<380$ & $700 \leq \mathrm{T}<716$ & 8 \\
\hline $380 \leq \mathrm{T}<390$ & $716 \leq \mathrm{T}<735$ & 7 \\
\hline $390 \leq \mathrm{T}<400$ & $735 \leq \mathrm{T}<752$ & 6 \\
\hline $400 \leq \mathrm{T}<410$ & $752 \leq \mathrm{T}<770$ & 5 \\
\hline $410 \leq \mathrm{T}<430$ & $770 \leq \mathrm{T}<805$ & 4 \\
\hline $430 \leq \mathrm{T}<450$ & $805 \leq \mathrm{T}<840$ & 3 \\
\hline $450 \leq \mathrm{T}<470$ & $840 \leq \mathrm{T}<880$ & 2 \\
\hline $470 \leq \mathrm{T}<490$ & $880 \leq \mathrm{T}<915$ & 1 \\
\hline $\mathrm{T} \geq 490$ & $\mathrm{~T} \geq 915$ & \\
\hline
\end{tabular}




\section{Cable Damage Mechanisms}

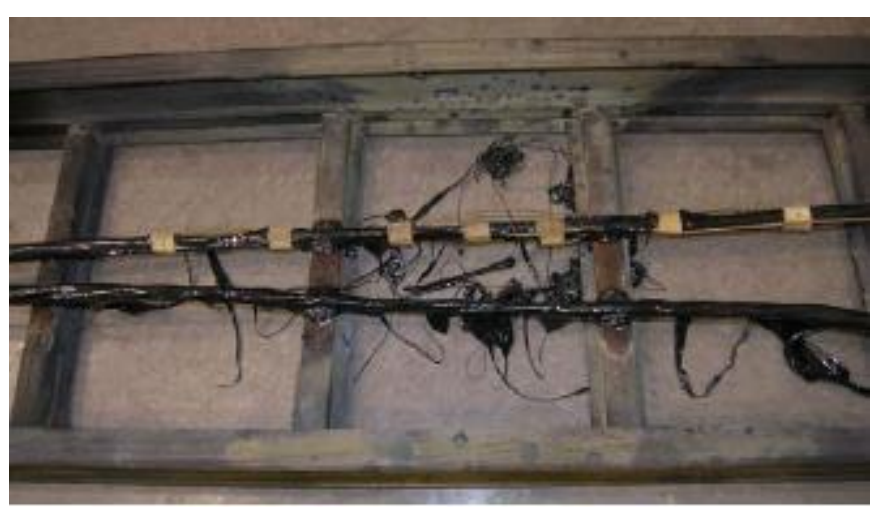

Thermoplastic

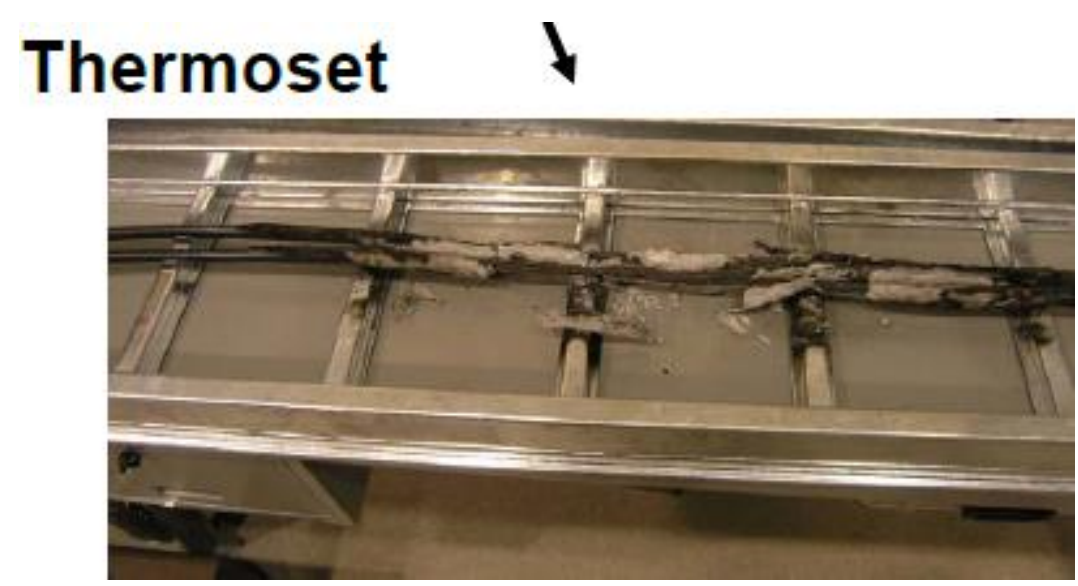




\section{Insights from Latest Research on Cable Fire Behavior (CAROLFIRE)}

- Inter-cable shorting of Thermoset cable is plausible, but less likely than intra-cable failure

- Inter-cable shorting between Thermoset and thermoplastic cables is plausible, but less likely than intra-cable failure

- Configurations requiring failure of $>3$ cables plausible

- No a priori limit on number of cables

- Scenario-dependent 


\section{Insights from Latest Research on Cable Fire Behavior (CAROLFIRE)}

- Multiple spurious operations in control circuits with properly sized current-power transformers:

- Inconclusive results, do not coincide with earlier NEI/EPRI results

- Fire-induced hot shorts lasting $>20$ minutes unlikely

- Spurious actuation of cold shutdown circuits not investigated by CAROLFIRE 


\section{Overview of the EPRI Fire-Induced Vulnerability Evaluation (FIVE) Methodology ${ }^{1}$}

1. EPRI TR-100370, Fire-Induced Vulnerability

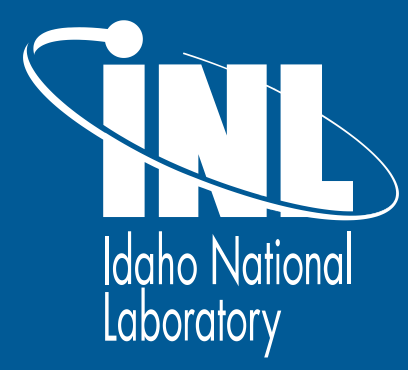
Evaluation (FIVE) Methodology Plant Screening Guide, Professional Loss Control, April 1992. 


\section{Learning Objectives}

- After studying this section you should be able to:

- List the three phases of the FIVE method.

- Outline the steps involved in each of the three phases of the FIVE method.

- Estimate the fire ignition frequency of a fire compartment. 


\section{FIVE Methodology}

- Developed to satisfy GL 88-20 requirements

- Oriented toward uncovering plant fire vulnerabilities.

- Uses the progressive screening approach at various stages.

- Provides guidelines to assess potential for fire propagation across compartments due to failure of barriers and penetration seals

- Provides tables, worksheets, and various equations for fire growth and spread analyses.

- Provides tables for estimating the availability of automatic detection and suppression systems 


\section{FIVE Methodology is Performed in Three Phases}

- Phase I: Fire Area Screening (Qualitative Analysis)

- Phase II: Fire Compartment Screening (Quantitative Analysis)

- Phase III: Plant Walk-Through and Verification 


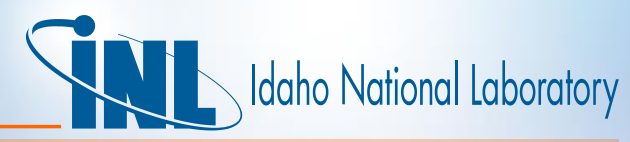

FIVE

\section{Overview}

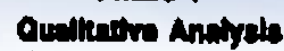
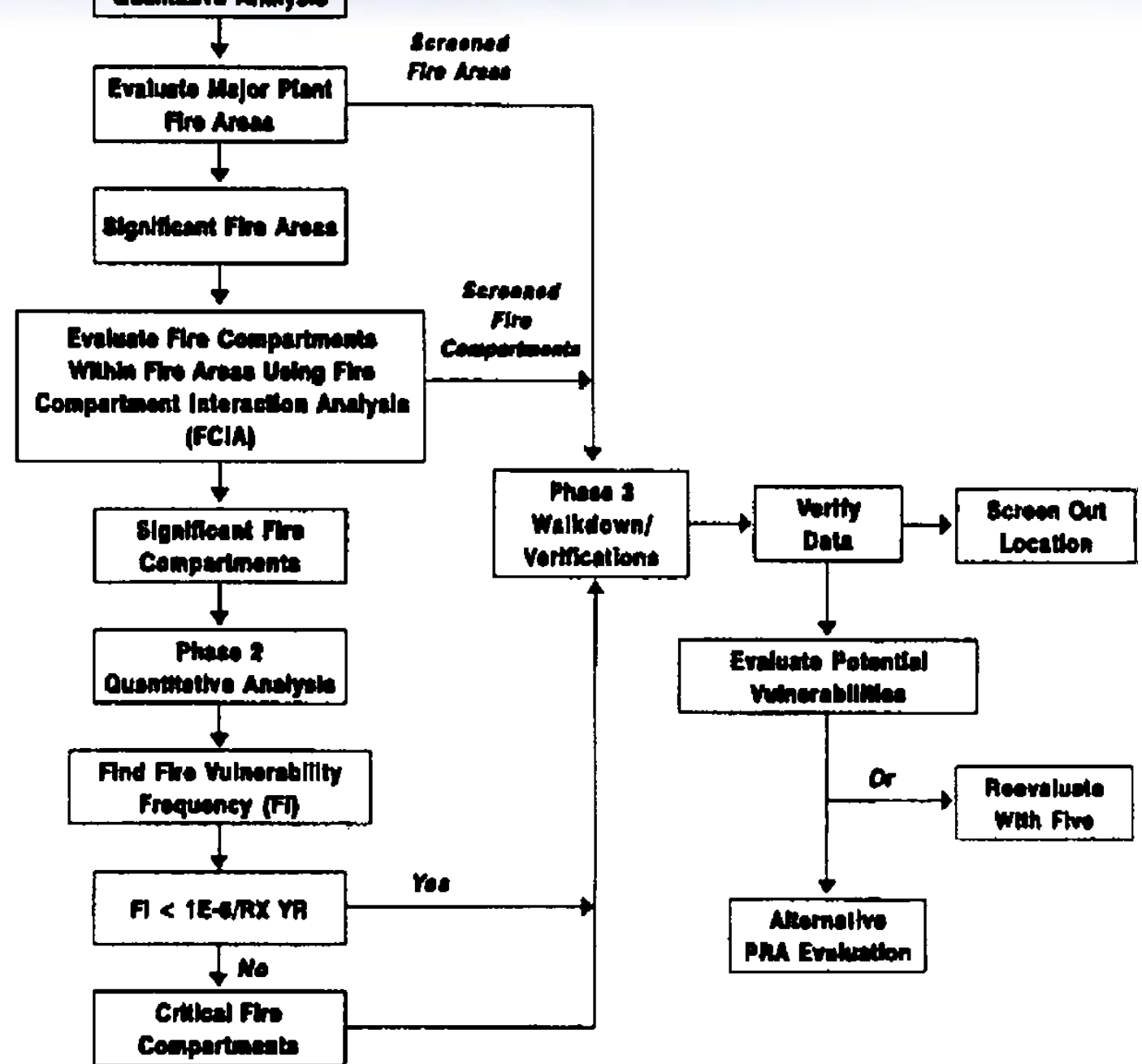


\section{Phase I Fire Area Screening Involves the Following Steps}

- Identify plant safe shutdown systems.

- Identify fire areas and associated compartments.

- Identify safe shutdown equipment in each fire compartment.

- For each fire area, perform qualitative screening analysis.

- For the unscreened fire compartments, perform the fire compartment interaction analysis. 


\section{Identify Plant Safe Shutdown Systems}

- Safe shutdown systems credited in Appendix R analysis.

- FIVE provides table format for documenting information. 


\section{Identify Fire Areas and Associated Compartments}

- Identify fire areas in the plant

- Use plant general arrangement drawings and Appendix R information

- Consider barriers that are included in the plant's inspection, testing, and maintenance program

- Define fire compartments within fire areas

- FIVE provides table format for documenting information 


\section{Identify Safe Shutdown Equipment in Each Fire Compartment}

- Use Appendix R safe shutdown equipment list.

- FIVE provides Safe Shutdown Equipment Detail Worksheet for documentation. 


\section{Qualitative Screening Criteria}

- A fire area can not be screened from further evaluation if:

- There are safe shutdown equipment, cables, or components in the area.

OR

- Following a fire in the area, there is a demand for safe-shutdown functions because the plant can not maintain normal plant operation.

- Fire is assumed to damage everything within the fire area boundaries. 


\section{Fire Compartment Interactions Analysis}

- Screened fire areas include all associated fire compartments.

- Unscreened fire areas may contain compartment(s) that are not important with respect to plant risk.

- Identify and screen unimportant fire compartments based on the potential for fire propagation

- Barrier rating

- Combustible loading

- Fire suppression features 


\section{Fire Compartment Interactions Analysis (continued)}

- Screening criteria for compartment boundaries:

- Boundaries between two compartments, neither of which contain safe shutdown components nor plant trip initiators.

- Boundaries that consist of a 2-hour or 3-hour rated fire barrier.

- Boundaries that consist of a 1-hour rated fire barrier with combustible loading in the exposing compartment $<80,000$ Btu per sq-ft.

- Boundaries in which the exposing compartment has a very low combustible loading $<20,000$ Btu per sq-ft and automatic fire detection.

- Boundaries in which both the exposing and exposed compartment have a very low combustible loading $<20,000$ Btu per sq-ft.

- Boundaries in which automatic fire suppression is installed over combustibles in the exposing compartment. 


\section{Fire Compartment Interactions Analysis}

(continued)

- Compartment is screened out if:

- All boundaries (adjacent compartments) of the compartment are screened out.

AND

- \{Compartment contains no safe shutdown equipment\} OR \{Following a fire, there is no demand for safe shutdown functions\}.

- Combine adjacent compartments with unscreened boundaries into a single compartment. 


\section{Phase II Fire Compartment Screening Involves the Following}

- Calculate compartment fire initiation frequency (FC).

- If FC is less than $1 \mathrm{E}-6$ per reactor year, compartment is screened from further analysis.

- Calculate unavailability of redundant/alternate shutdown path (PRA).

- For unscreened compartment, if FC•PRA is less than 1E-6 per reactor year, screen compartment from further analysis.

- If not screened-out, then perform fire hazard analysis and combustible material evaluation. 


\section{Compartment Fire initiation Frequency (FC)}

- Based on the type and amount of fire source equipment in location.

- Use fire ignition source frequencies, FI, from the EPRI Generic Fire Events Database.

- Determine weighting factor for the location (WFL).

- Determine weighting factor for each type of ignition source (WFIS).

- Compartment fire initiation frequency:

- $\mathrm{FC}=\Sigma \mathrm{FI} \cdot \mathrm{WFL} \cdot \mathrm{WFIS}$ 


\section{Determination of Location Weighting Factor, WFL}

\begin{tabular}{|c|l|}
\hline $\begin{array}{c}\text { Weighting Factors for adjusting generic location fire frequencies } \\
\text { to plant-specific locations }\end{array}$ \\
\hline Plant Location & \multicolumn{1}{c|}{ Weighting Factors (WFL) } \\
\hline Auxiliary Building (PWR) & $\begin{array}{l}\text { The number of units per site } \\
\text { divided by the number of } \\
\text { buildings. }\end{array}$ \\
\hline Reactor Building (BWR) & $\begin{array}{l}\text { The number of units per site } \\
\text { divided by the number of } \\
\text { buildings. }\end{array}$ \\
\hline [Does not include containment] Spreading Room & $\begin{array}{l}\text { The number of units per site } \\
\text { divided by the number of rooms } \\
\text { per site. }\end{array}$ \\
\hline Plant-Wide Components & The number of units per site. \\
\hline
\end{tabular}




\section{Determination of Ignition Source Weighting Factor, WFIS}

\begin{tabular}{|l|l|c|l|}
\hline \multicolumn{4}{|c|}{ Fire Ignition Sources and Frequencies by plant location } \\
\hline Plant Location & $\begin{array}{l}\text { Ignition/Fuel } \\
\text { Source }\end{array}$ & $\begin{array}{c}\text { Fire Frequency } \\
\text { (per year) }\end{array}$ & $\begin{array}{l}\text { Method for } \\
\text { Calculating WFIS }\end{array}$ \\
\hline $\begin{array}{l}\text { Auxiliary Building } \\
\text { (PWR) }\end{array}$ & $\begin{array}{l}\text { Electrical } \\
\text { Cabinets, } \\
\text { Pumps }\end{array}$ & $1.9 \times 10^{-2}$ & $\begin{array}{l}\text { Divide the number } \\
\text { of ignition sources } \\
\text { in the fire } \\
\text { compartment by } \\
\text { the number in the } \\
\text { location. }\end{array}$ \\
\hline $\begin{array}{l}\text { Reactor Building } \\
\text { (BWR) }\end{array}$ & $\begin{array}{l}\text { Electrical } \\
\text { Cabinets, } \\
\text { Pumps }\end{array}$ & $5.0 \times 10^{-2}$ & $\begin{array}{l}\text { Divide the number } \\
\text { of ignition sources } \\
\text { in the fire } \\
\text { compartment by } \\
\text { the number in the } \\
\text { location. }\end{array}$ \\
\hline $\begin{array}{l}\text { Cable Spreading } \\
\text { Room }\end{array}$ & Electrical Cabinets & $3.2 \times 10^{-2}$ & $\begin{array}{l}\text { No ignition source } \\
\text { weighting factor is } \\
\text { necessary }\end{array}$ \\
\hline
\end{tabular}




\section{Fire Area/Compartment Ignition Source Data Sheet (ISDS) Auxiliary Building}

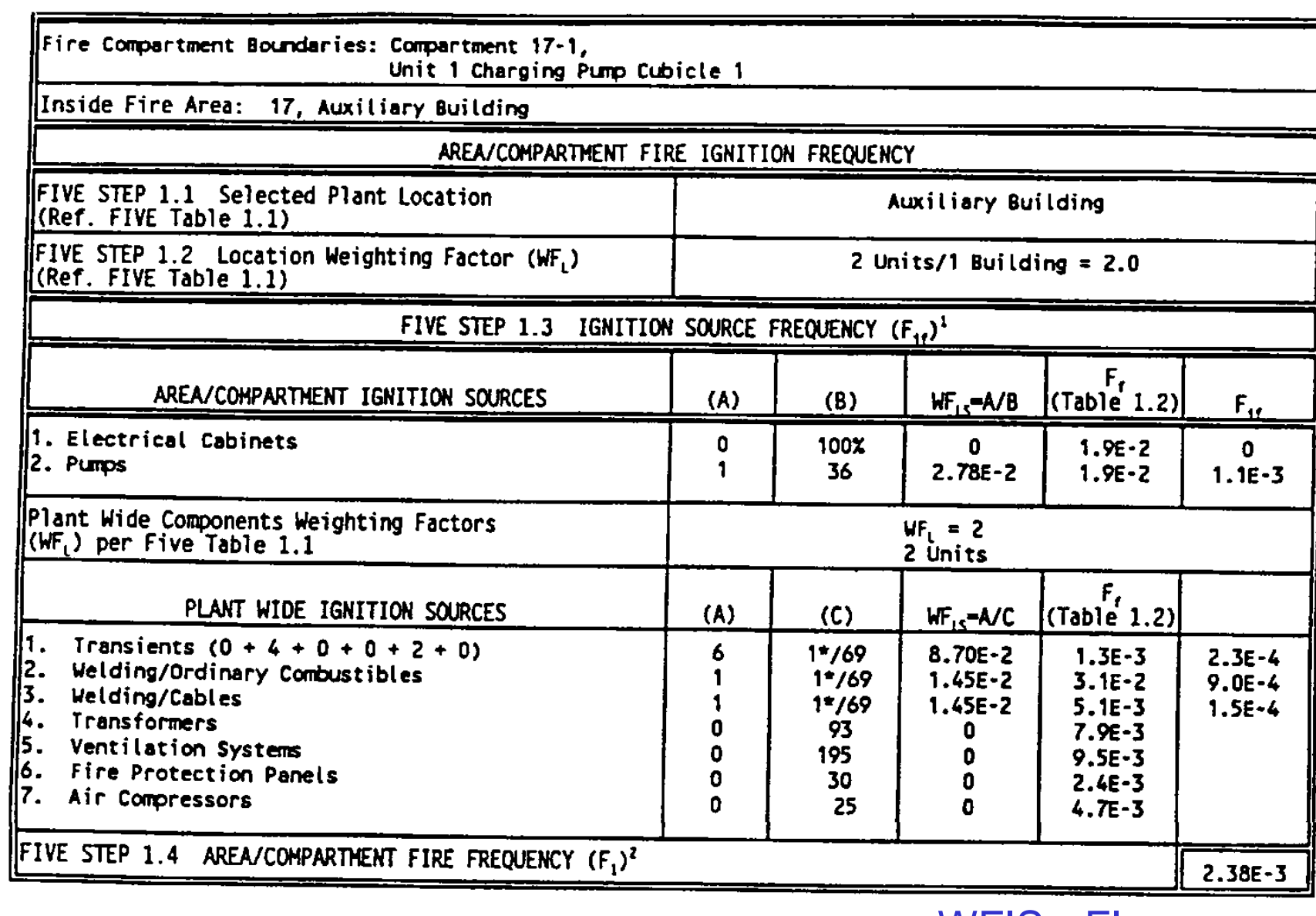




\section{Fire Hazard and Combustible Material Analysis/Fire Growth and Propagation}

- A process for evaluating the probability of critical combustible loading for the compartment.

- Fixed and transient combustibles are considered.

- Fire suppression prior to target equipment damage is considered.

- FIVE provides the algorithm, worksheets, and look-up tables for analysis. 


\section{Fire Hazard and Combustible Material Analysis (continued)}

- Evaluate fixed and transient combustible exposures.

- Identify fire sources.

- Identify target component.

- Develop fire scenarios.

- Determine critical combustible loading.

- Use FIVE evaluation worksheets.

- Determine fire suppression (automatic and/or manual) unavailability.

- Determine critical combustible (transient) loading probability. 


\section{Critical Combustible (Transient) Loading} Probability

- The CCL probability is dependent on the following factors:

- Probability of combustibles located within a critical range of target, $\mathrm{P}_{\mathrm{r}}$.

- Probability of combustibles being exposed, $\mathrm{P}_{\mathrm{e}}$.

- Frequency of combustible present in the compartment.

- Frequency of combustible material inspection.

- Probability of critical transient combustible loading is given by:

$$
\mathrm{P}_{\mathrm{r}} \cdot \mathrm{P}_{\mathrm{e}} \cdot \mathrm{P}_{\mathrm{p}}
$$

where $P_{p}$ is the probability of critical amount of transient combustibles being present between inspections. 


\section{Compartment Critical Combustible Loading Probability and Fire Damage Frequency}

- Probability of compartment critical combustible loading fire is given by:

$$
P_{C L}=P_{f x}+P_{r} \cdot P_{e} \cdot P_{p}
$$

where $P_{f x}$ is for a fixed source in the compartment, and is evaluated first.

- Transient source not considered if fixed source has impact on target $\left(P_{f x}=1\right)$. 


\section{Compartment Critical Combustible Loading} Probability and Fire Damage Frequency

(continued)

- Overall fire damage frequency for compartment is given by:

$$
F_{F D}=F_{C} \cdot P_{R A} \cdot P_{C L} \cdot U_{F S}
$$

$F_{C}$ is the compartment fire frequency

$P_{R A}$ is the unreliability of redundant/alternate shutdown path

$U_{F S}$ is the unreliability of fire suppression

- Compartment is screened from further analysis if $\mathrm{F}_{\mathrm{FD}}$ is less than 1E06 per reactor year.

- Compartments not screened are significant fire compartments. 


\section{Evaluate Potential Fire Vulnerabilities}

- For the unscreened compartments:

- Accept the results.

- Implement administrative and/or hardware changes.

- Refine the analysis for the unscreened compartments.

- Use PRA models to determine risk significance of unscreened compartments. 


\section{Phase III Plant Walk-Through and Verification Involves the Following Steps}

- Performed before or after Phase I/II.

- Collect data and confirm information gathered for analysis.

- Verify assumptions and calculations.

- Plant walkdown guide/checklist provided. 


\section{Example - Summary of FIVE Phase I Screening}

\begin{tabular}{|c|c|l|}
\hline Building & $\begin{array}{c}\text { Total } \\
\text { Number of } \\
\text { Fire Zones }\end{array}$ & \multicolumn{1}{|c|}{ FIVE Phase I Screening } \\
\hline Reactor Building & 33 & $\begin{array}{l}\text { 15 fire zones can be screened out on } \\
\text { the basis that a postulated fire does } \\
\text { not propagate into adjacent fire } \\
\text { zones and 1 fire zone does not } \\
\text { impact safe shutdown equipment. } \\
\text { (The drywell is dismissed due to the } \\
\text { N2 atmosphere - consistent with } \\
\text { FIVE.) Total of 16 zones screen } \\
\text { out. }\end{array}$ \\
\hline Turbine Building & 20 & $\begin{array}{l}\text { 8 fire zones can be screened out as } \\
\text { described above. }\end{array}$ \\
\hline Control Building & 9 & $\begin{array}{l}\text { 2 fire zones can be screened out as } \\
\text { described above. }\end{array}$ \\
\hline Radwaste/Offgas \\
Building & 9 & Entire building screens out. \\
\hline
\end{tabular}




\section{Example - Summary of FIVE Phase I Screening (continued)}

\begin{tabular}{|c|c|c|}
\hline Building & $\begin{array}{c}\text { Total } \\
\text { Number of } \\
\text { Fire Zones }\end{array}$ & FIVE Phase I Screening \\
\hline $\begin{array}{c}\text { Pump House/Intake } \\
\text { Structure }\end{array}$ & 10 & $\begin{array}{l}3 \text { fire zones can be screened out as } \\
\text { described above. }\end{array}$ \\
\hline $\begin{array}{c}\text { Security Center/ } \\
\text { Technical Support } \\
\text { Center/DAC }\end{array}$ & 9 & Entire building screens out. \\
\hline $\begin{array}{c}\text { Administration } \\
\text { Building }\end{array}$ & 3 & Entire building screens out. \\
\hline $\begin{array}{c}\text { Low Level Radwaste } \\
\text { Processing and Storage } \\
\text { Facility }\end{array}$ & 21 & Entire building screens out. \\
\hline TOTAL & 114 & $\begin{array}{l}71 \text { fire zones screen out - 43 left } \\
\text { unscreened. }\end{array}$ \\
\hline
\end{tabular}




\section{Example - Phase I Screening Process}

Phase I Step \# 4 Initial Quick Screening

IF SSE $=\mathrm{N}$ AND FIE $=\mathrm{N}$ THEN SCREEN $=\mathrm{Y}$

ELSE SCREEN $=\mathrm{N}$

Phase I Step \# 5 Only Compartments with Safe Shutdown Equipment Addresses

IF SSE $=Y$ AND FIE $=Y$ THEN SCREEN $=N$

IF SSE $=Y$ AND FIE $=N$ THEN SCREEN $=Y$

ELSE SCREEN $=\mathrm{N}$

Phase I Step \# 6 Investigate Potential for Fire Spread Between Compartments

IF PFS $=N$ AND $(S S E=N$ OR FIE $=N)$ THEN SCREEN $=Y$

ELSE SCREEN $=\mathrm{N}$

SSE = Safe Shutdown Equipment

$\mathrm{FIE}=$ Fire Initialed Event

PFS $=$ Potential for Fire Spread between compartments 


\section{Example - FIVE Phase I Screening}

wo. FIRE AREA

COMP IO CONPARTHENT DESCRIPTION

PHASE I PMASE I PMASE I

con 10 conparthent DeschipTJON

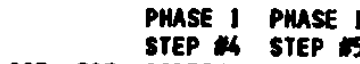
STEP if

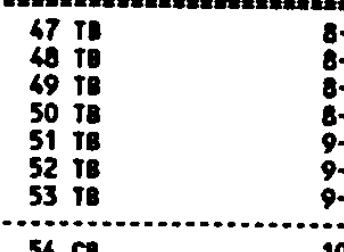

8-6 Dfeesl Generator Dey Tenk Rocm - Division II

Dieael Generator Day Tenk Room - Oivision I

Dealinaral lzer Pup and Tenk Celle

Turbine Operating floor (North End)

Turbin operating floor (Aree Between the shield Wal is)

Turbine Operoting floor (South End)

SSE FIE SCREEN SCREEM PFS SCREEM

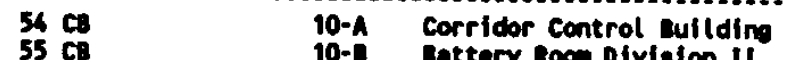

$55 \mathrm{CB}$ Eattery Rocm Division II

$57 \mathrm{CB}$

$58 \mathrm{CB}$

Ettery hoom Moneasentiel

Eatery Rocan Division

Esential Switchpear Rocm Division 11

$59 \mathrm{CO}$

10-E

$60 \mathrm{CB}$

$62 \mathrm{Cs}$

$10-\beta$

Ceble spreading hocm

Control lullding WYAC Room

63 Radvoffgas Oldo

65 Red/Offoes Bld $13-\mathrm{C}$

66 Rad/Offgas bldo 13-D

67 Radroffoes Bld

68 Red/Offon Btdo

69 Red/offges Btdo

70 Redroffoes itch $15-$

71 Radiotfnes eld

Rectuste Druming and chipoin

Redveste Treationt and Access Ares

Reduneste Precoet and Access Aree

Redraste Control Roon

Machine shop

Offoas Charcoel Adsorber Veult

offeas Control and atyeol Area

offoes Prefilter and Condanser area offons steck

72 Puphouse/Intake 16-A

72 Puphouse/Intake $16-1$

Puphouse RHR and ESU PUP Area Division II

74 Pumphouse/Intake 16-C

T3 Pumphouse/lintake 16-D

76 Puphouse/Intake 16-E

7 Puphouse/Intake 16-F

78 Punphouse/Intoke 17-A

80 Puphouse/Intake 17-c

81 Puiphouse/Intake 17-0

Puphouse RHR and ESU PUip Area Division I

Punphouse Main Pup Roon

Puphouse Difeel Fire Putp

Puphouse Fire Pun Day Tank

Puphouse Safety-Related Piping

Intake Structure Pup Ares Division 1

Intake Structure Pupp Ares Division it

Intake.structure Screen Aree olvision I

intake structure sereen Ares olvision it

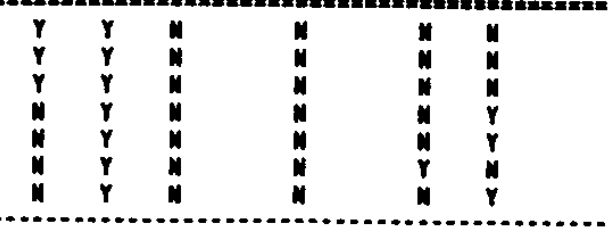

82 securlty/Tsc/onc in-a

\section{Security Center securlty Power}

03 security/Tsc/0AC 10-

84 security/Tse/DAC $18-\mathrm{C}$

os security/Tsc/DAC 18-D

06 securlty/rec/0AC 19-A

8 security/TSC/DAC $19-\mathrm{C}$

security Center Lobby, Ingrese and Earese search Aree

security Contr kin, Dir. Off, Lekr, Eott, \& Elect/Inst nepoir time

Security Center Equipenent koom

Tech support Ctr, Doc Control Ctr, LIbrary, and offlice Area

Tecinicel support Center Hechenical Roo

Date Acquisition Center - Conpurter Rocm

Date Acquidition Center - First floor Area

$\begin{array}{ll}y & y \\ y & y \\ y & y \\ y & y \\ y & y \\ y & y \\ Y & y \\ y & y \\ y & y\end{array}$

n N

N

n

N

\begin{tabular}{|c|}
\hline $\begin{array}{l}y \\
y \\
y \\
y \\
y \\
y \\
y \\
y \\
y\end{array}$ \\
\hline
\end{tabular}

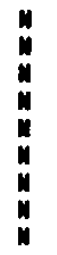

\begin{tabular}{|c|c|c|}
\hline$N$ & & $\begin{array}{l}\gamma \\
\gamma \\
\gamma \\
\gamma \\
\gamma \\
\gamma \\
\gamma \\
\gamma \\
\gamma\end{array}$ \\
\hline
\end{tabular}

os security/tec/oac 19-0 


\section{FIVE Phase I Screening (cont'd)}

WO. FIRE AREA

COMP 10 COMPARTENT DESCRIPTIOA

PMASE I 'PHASE I PHASE I

STEP 6

-

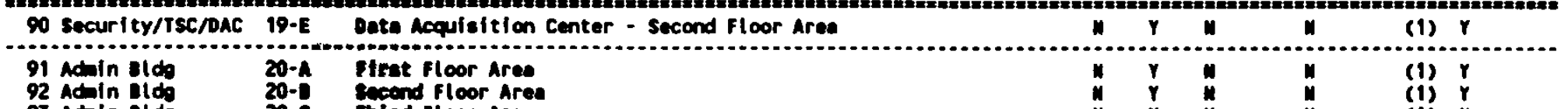

93 Adain Blds

of LLRPSF

\%5 LLRPSF

red floor Ares

(1) $y$

\% LLRPSF

98 LLRPSF

9 LLRPSF

100 LLRPSF

101 LLRPSF

102 LLRPSF 21.I Sup hoom (RoO 809)

21-A Surge Tenk Roce (Rog 802)

21-8 Future Expansion Morth (Room 801)

21-C DAN Storege Ares (Roci 804)

Spend Resin in storege Area (Room 803)

21-E Truek Loed Bay, Accese Areas, \& Mez2. (Ris 800, 805, 806, 8 842) avoc inepection office (Rooi BOS)

21-6 Corr, Mise ten Expn. Aree (Ro 807, 810, 826, 834-837, 830-849) Contéliner storeos Aree (Room 838)

103 LLRPSF

104 LLRPSF

IOS LLRPSF
106 LLRPSF

107 LLRPSF

108 LLRPSF

109 LLRPSF

110 LLRPSF

111 LLRPSF

112 ULPSF

113 LLRPSF

21-J HP Office and Count Room (Room 832, 833)

21-K Processing Ares (Roces 811 thru 825)

21-L Mask Cleaning Aree (Rocm 831)

21-M Rail Iroed Dey Extempion (Room 827)

21-i IVAC \& Elec. E0 Room (Room 862)

Hydrolazino Decontemination Aree (Room 829)

21-P Storeas and Corridor (Rocm 859, 861, 663)

21-0 Mezzenin Future Expermion (Roc 860 )

21-R Ruduste Offices \& Crane Control Room (hoow 844-858)

21-8 Tool \& Equipent storage (Rocm 828)

114 LLRPSF

21-T future storege Area 2 Chemistry Dept Equip koon (Rocm a43)

future Expandion Upper Level (hoom 864)

N $Y$ U

notes:

(1): As each of these buildings conteins no sofe shutdoun equipsent, the individul

compartinents of eech bullding ore conservetively combined into e einole fire compartisent

so ae not to unnecessarily expend effort performing fire Compartiment interaction malysis.

PMASE I STEP 4 SCREEM: - Initial quick screen

- If SSE $=$ N AND FIE

- ELSE SCREENMAN

PMASE I STEP is SCREEN: - Only comportments with safe shutdoun equipinent addreased

- If SSEaY AMD FIEar THEN SCREEN=n

- If sSEar Alo fiean then scheEN=r

- ELSE SCREEMAn

PHASE I STEP 46 scREEW: - Investigate potential for fire apread betwen compartimente

- If PFS=il AND (SSE

- Else scheen=a 


\section{Example - ISDS Worksheet}

Fire Compartment Ignition Source Data Sheet (ISDS)

\begin{tabular}{|c|c|c|c|c|c|c|}
\hline \multicolumn{7}{|c|}{$\begin{array}{l}\text { Compartment Fire lonition Frequency } \\
\text { Step } 1.1 \text { Ptent Locetion iD }\end{array}$} \\
\hline Step 1.2 & Location Welghting factor (WFL) & $1.00 E+\infty$ & & & & \\
\hline \multicolumn{7}{|c|}{ Compartment lanition Sources (FIF) } \\
\hline $\begin{array}{l}1 \\
2 \\
3 \\
4 \\
5 \\
6 \\
7\end{array}$ & $\begin{array}{l}1 \text { Electrical Cabinets } \\
2 \text { Pumpe } \\
3 \\
4 \\
5 \\
3 \\
7\end{array}$ & $\begin{array}{l}\text { Sources in } \\
\text { compertment } \\
\text { (A) }\end{array}$ & $\begin{array}{c}\text { Sources in } \\
\text { Plant Location } \\
\text { (B) } \\
3.83 E+02 \\
7.90 E+01 \\
0.00 E++\infty \\
0.00 E++\infty \\
0.00 E++\infty \\
0.00 E+\infty 0 \\
0.00 E+\infty\end{array}$ & $\begin{array}{c}\text { Weighting } \\
\text { Facto } \\
\text { WFLS }=(A)(B) \\
0.00 E+\infty \\
2.53 E-02 \\
0.00 E++\infty \\
0.00 E++\infty \\
0.00 E+\infty \\
0.00 E+\infty \\
0.00 E+\infty\end{array}$ & $\begin{array}{c}\text { Fire } \\
\text { Frequency } \\
\text { (FF) } \\
5.0 E-02 \\
2.5 E-02 \\
0.0 E+\infty \\
0.0 E+\infty \\
0.0 E+\infty \\
0.0 E+\infty \\
0.0 E+\infty\end{array}$ & $\begin{array}{c}\text { Ignition Source } \\
\text { Frequency } \\
\text { (FIF) } \\
0.0 E+\infty \\
6.3 E-04 \\
0.0 E+\infty \\
0.0 E+\infty \\
0.0 E+\infty \\
0.0 E+\infty \\
0.0 E+\infty\end{array}$ \\
\hline Plant Whe & 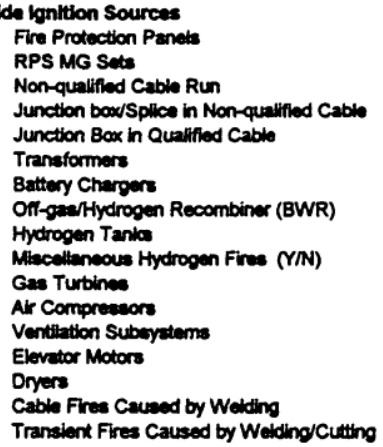 & 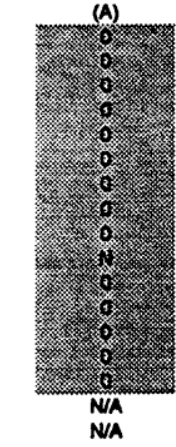 & $\begin{array}{l}(C) \\
0.00 E+\infty 0 \\
4.00 E+\infty \\
0.00 E+\infty \\
0.00 E+\infty \\
0.00 E+\infty 0 \\
1.60 E+01 \\
0.00 E+\infty 0 \\
0.00 E+\infty 0 \\
0.00 E+\infty \\
7.70 E++1 \\
0.00 E++\infty \\
0.00 E++0 \\
1.00 E++02 \\
0.00 E++0 \\
0.00 E+\infty \\
7.70 E+01 \\
7.70 E+01\end{array}$ & $\begin{array}{l}(A)(C) \\
0.00 E+\infty \\
0.00 E+\infty \\
0.00 E+\infty \\
0.00 E+\infty \\
0.00 E+\infty \\
0.00 E+\infty \\
0.00 E+\infty \\
0.00 E+\infty \\
0.00 E+\infty \\
0.00 E+\infty \\
0.00 E++\infty \\
0.00 E++\infty \\
0.00 E++\infty \\
0.00 E++\infty \\
0.00 E+\infty \\
1.30 E-02 \\
1.30 E-02\end{array}$ & $\begin{array}{l}2.4 E-03 \\
5.5 E-03 \\
6.3 E-03 \\
1.6 E-03 \\
.6 E-03 \\
7.9 E-03 \\
4.0 E-03 \\
8.6 E-02 \\
3.2 E-03 \\
3.2 E-03 \\
3.1 E-02 \\
4.7 E-03 \\
9.5 E-03 \\
6.3 E-03 \\
8.7 E-03 \\
5.1 E-03 \\
3.1 E-02\end{array}$ & $\begin{array}{r}\text { Reforence } 1.2 \\
0.0 E+\infty \\
0.0 E+\infty \\
0.0 E+\infty \\
0.0 E+\infty \\
0.0 E+\infty \\
0.0 E+\infty \\
0.0 E+\infty \\
0.0 E+\infty \\
0.0 E+\infty \\
0.0 E+\infty \\
0.0 E+\infty \\
0.0 E+\infty \\
0.0 E+\infty \\
0.0 E+\infty \\
0.0 E+\infty \\
6.6 E-\infty \\
4.0 E-04\end{array}$ \\
\hline & 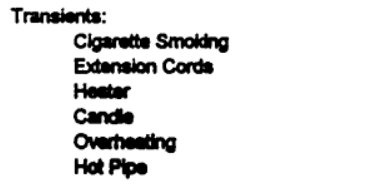 & 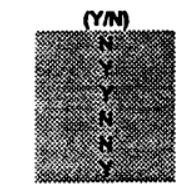 & $\begin{array}{l}8 \\
0 \\
4 \\
3 \\
0 \\
0 \\
1\end{array}$ & & $1.3 E-03$ & $1.4 E-04$ \\
\hline $\begin{array}{l}\text { Compart } \\
\text { Step } 1.4\end{array}$ & 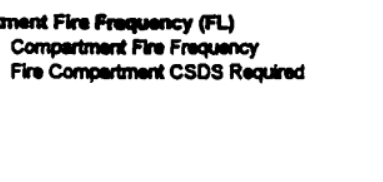 & $\begin{array}{c}1.24 E-03 \\
Y \in E\end{array}$ & $\begin{array}{l}\text { Notes: } \\
\text { (A) Number } \\
\text { (B) Total Nu } \\
\text { (C) Toted Nu }\end{array}$ & $\begin{array}{l}\text { of lonition Sou } \\
\text { umber of lonito } \\
\text { umber of lonito }\end{array}$ & $\begin{array}{l}\text { Compertm } \\
\text { cos in Selloc } \\
\text { cosicompe }\end{array}$ & $\begin{array}{l}\text { dPlant Location } \\
\text { nents in Plant } \\
\text { if }\end{array}$ \\
\hline
\end{tabular}




\section{Example - Fire Ignition Frequency Estimates}

\begin{tabular}{|c|c|}
\hline Fire Compartment & Fire Ignition Frequency (Per Yr) \\
\hline $1-\mathrm{A}$ & $1.24 \mathrm{E}-03$ \\
\hline $1-\mathrm{B}$ & $2.64 \mathrm{E}-03$ \\
\hline $1-\mathrm{C}$ & $7.34 \mathrm{E}-04$ \\
\hline $1-\mathrm{D}$ & $1.87 \mathrm{E}-03$ \\
\hline $1-\mathrm{E}$ & $1.94 \mathrm{E}-03$ \\
\hline $1-\mathrm{F}$ & $4.02 \mathrm{E}-03$ \\
\hline $1-\mathrm{G}$ & $6.04 \mathrm{E}-04$ \\
\hline $1-\mathrm{H}$ & $1.24 \mathrm{E}-03$ \\
\hline $2 \mathrm{~A} / 2 \mathrm{~B} / 2 \mathrm{C}$ & $2.43 \mathrm{E}-02$ \\
\hline $2-\mathrm{D}$ & $6.62 \mathrm{E}-04$ \\
\hline
\end{tabular}




\section{Example - Fire Ignition Frequency Estimates (continued)}

\begin{tabular}{|c|c|}
\hline Fire Compartment & Fire Ignition Frequency (Per Yr) \\
\hline $2-\mathrm{G}$ & $6.04 \mathrm{E}-04$ \\
\hline $3 \mathrm{~A} / 3 \mathrm{~B}$ & $2.73 \mathrm{E}-02$ \\
\hline $3-\mathrm{D}$ & $7.82 \mathrm{E}-03$ \\
\hline $4-\mathrm{A}$ & $3.18 \mathrm{E}-03$ \\
\hline $7 \mathrm{~A} / 8 \mathrm{~A} / 8 \mathrm{C} / 8 \mathrm{D} / 9 \mathrm{~B}$ & $1.30 \mathrm{E}-02$ \\
\hline $7-\mathrm{B}$ & $4.15 \mathrm{E}-03$ \\
\hline $7-\mathrm{C}$ & $1.07 \mathrm{E}-03$ \\
\hline $7-\mathrm{E}$ & $4.06 \mathrm{E}-03$ \\
\hline $8-\mathrm{F}$ & $2.97 \mathrm{E}-02$ \\
\hline $8-\mathrm{G}$ & $6.45 \mathrm{E}-04$ \\
\hline $8-\mathrm{H}$ & $2.97 \mathrm{E}-02$ \\
\hline
\end{tabular}




\section{Example - Phase III Walkdown Checklist}

\begin{tabular}{|c|c|c|c|}
\hline \multicolumn{4}{|l|}{ AREA DESCRIPTION: Laydown Area } \\
\hline \multicolumn{4}{|l|}{ FIRE ZONE: $3-A$} \\
\hline BUILDING: Reactor Building & \multicolumn{3}{|c|}{ ELEVATION: $786^{\prime}-0^{*}$} \\
\hline \multicolumn{4}{|c|}{ WALKDOWN VERIFICATION PURPOSE(S) } \\
\hline \multicolumn{4}{|c|}{$\begin{array}{l}\text { - Verification of IPEEE fire analysis issues } \\
\text { - } \\
\text { Other }\end{array}$} \\
\hline \multicolumn{4}{|c|}{ WALKDOWN VERIFICATION CHECKLIST } \\
\hline \multirow[b]{2}{*}{ Verification Item } & Veri & & \multirow[b]{2}{*}{ Comments } \\
\hline & Yes & No & \\
\hline $\begin{array}{l}\text { 1. Verify thut the ignition sources in this fire } \\
\text { compartment are as listod in the Ignition Source } \\
\text { Data Sheet. }\end{array}$ & & & \\
\hline $\begin{array}{l}\text { 2. Verify that the fire protection systems in this fire } \\
\text { compartment are as listod in the Critical Screen } \\
\text { Data Sheet. }\end{array}$ & & & \\
\hline $\begin{array}{l}\text { 3. Verify that, in the event of spurious fire protection } \\
\text { system actuation, rodundant safe shutdown trains } \\
\text { are not susceptible to damage from the } \\
\text { suppreseant. Consider coverage of suppreesion } \\
\text { system and existing barriers/shields protecting } \\
\text { equipment. }\end{array}$ & & & \\
\hline $\begin{array}{l}\text { 4. Verify the fire barriers, fire dampers, fire doors, } \\
\text { and penetration seals aro muintrined under the } \\
\text { plent surveillmoo and maintenance program. }\end{array}$ & & & \\
\hline $\begin{array}{l}\text { 5. Verify that the boundaries of this fire area setisfy } \\
\text { the definition for fire compartment barriers as } \\
\text { deacribed in FIVE. }\end{array}$ & & & \\
\hline
\end{tabular}




\section{Example - Phase III Walkdown Checklist (continued)}

AREA DESCRIPTION: Loydown Area

FIRE ZONE: 3-A

BUILDING: Reactor Building

ELEVATION: $786^{\prime}-0^{\circ}$

6. Verify FCIA screening criteris selected for the compertment bounderies is appropriate.

7. Verify that fixed combustibles are as listed in the Fire Henards Anelysis.

8. Verify quantities of fixed combustibles are as listed on the Critical Combustible Data Shoet.

9. Identify any flammuble liquid or gas storage vessels or piping (e.8., H2) and whether these ane outliers with respect to leakage under seismic conditions.

10. Note the existence and dimensions of dikes that mould contain flammable liquid spills.

11. Review expected operations in area and verify thet the expected transient combustibles in this ares are as considered in the Critical Screen Data Shoed.

12. Verify that the approximate quantitics of expected transieat combustibles is as considered in the Critical Combustible Dath Shoet.

13. Verify that the approximate distance between fire sources and targets is consistent with that used in the fire modeling of this fire compartment.

14. Review controls on control room panels to determine the extent of damage given the postulated firo event.

15. Verify that control room back panels are compartmentalized so es to minimize the spread of fire from one pand to another.

16. Verify that wetemal doors and vents are protected by interior missile barriers.

ANALYST:

DATE: 


\section{Fire PRA}




\section{Update on Fire PRA}

- Joint NRC-RES/EPRI development effort

- NUREG/CR-6850 (September 2005)

EPRI 1011989

- Aimed primarily at practitioners of Fire PRA

- Assumes Fire PRA team comprises experts in:

- Fire analysis

- General PRA

- Human Reliability Analysis

- Electrical Analysis 


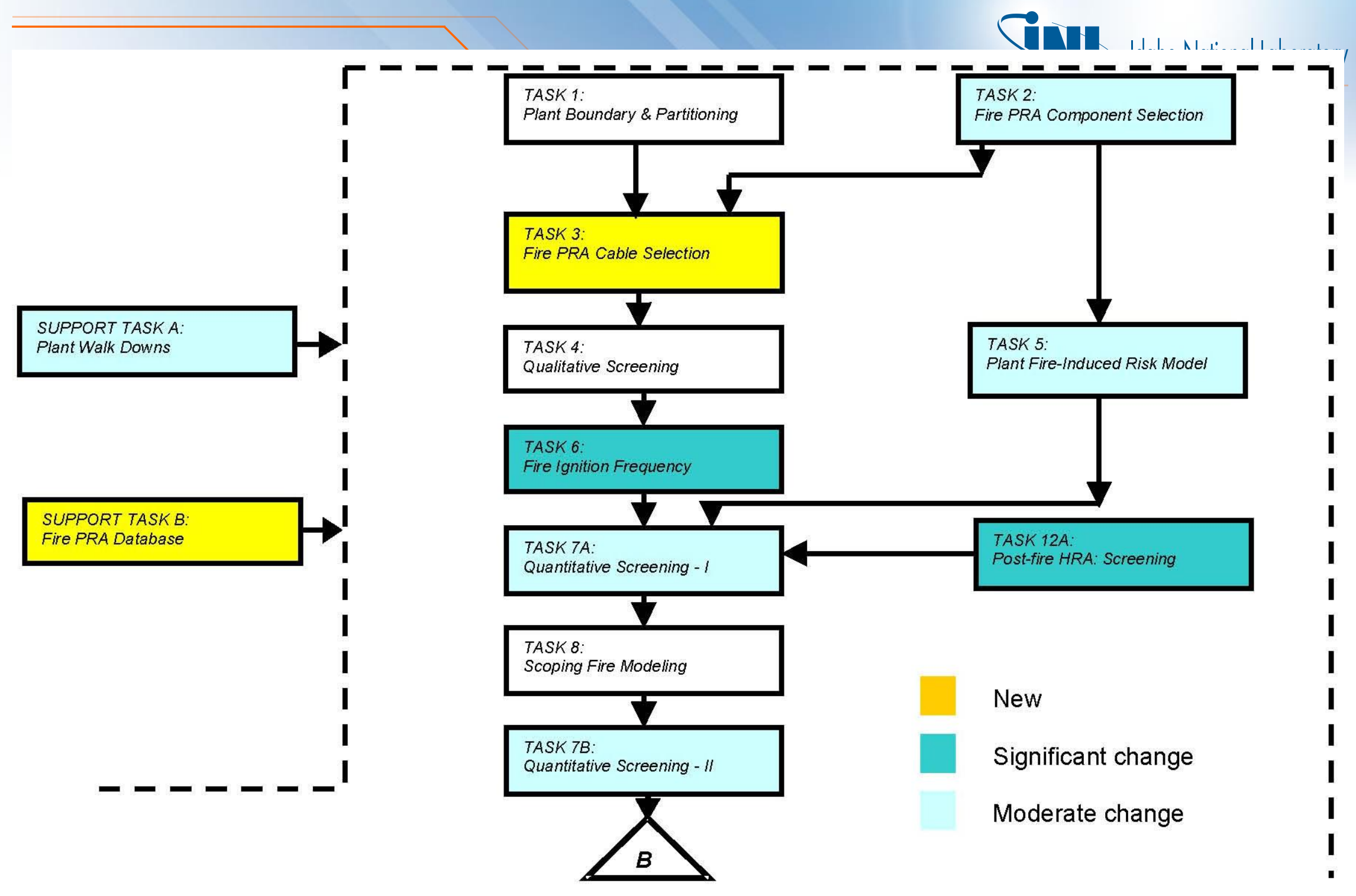

Figure 1

Overview of the Fire PRA Process 


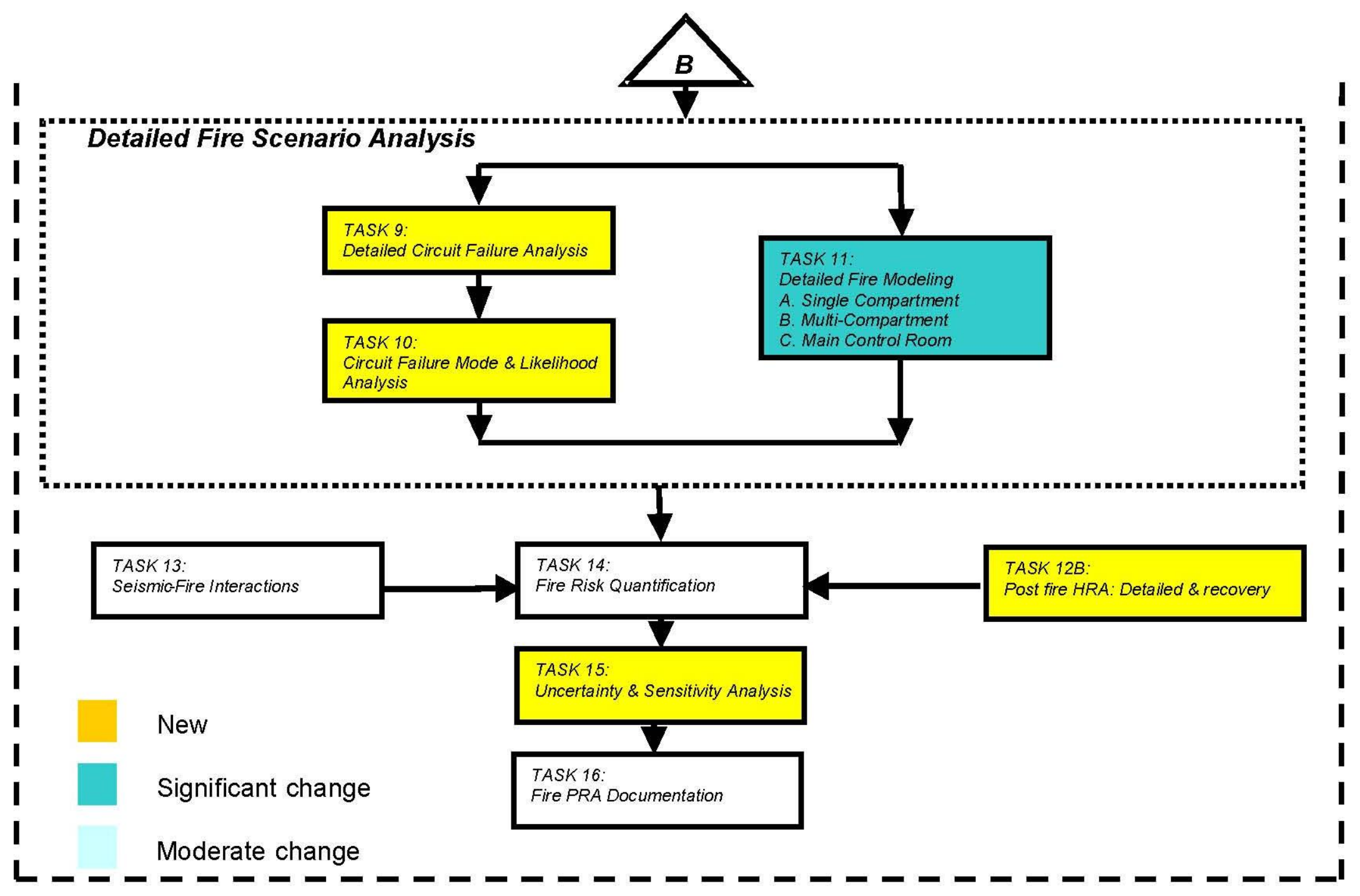

Figure 1

Overview of the Fire PRA Process (Continued 


\section{Task 1 - Plant Boundary \& Partitioning}

- Two-phase task

- Global plant areas (boundary) identified

- E.g., at building level

- Fire "Compartments" identified

- Effective at containing fire damage under most conditions

- This is the basis for subsequent analysis

- Typically defined by physical fire barriers

- Not necessarily the same as regulatory defined fire areas or zones 


\section{Task 2 - Component Selection}

- Components selected become focus of analysis

- Utilizes info from Internal Events PRA and Fire Safe Shutdown Analysis

- Internal events PRA reviewed and applicable core damage sequences identified

- Also need to consider spurious actuation of equipment important to human response

- As with most PRA tasks, this is an iterative process

- Results support Cable Selection (Task 3) 


\section{Task 3 - Cable Selection}

- Objective is to identify important cables/circuits and their routing

- Starts with component list from task 2

- Vital reference information:

- Appendix R circuit analysis

- Plant-specific cable location data

- Resource of last-resort - manual review of drawings and cable location walkdowns

- Together with component list, identifies important fire compartments/areas/locations 


\section{Task 4 - Qualitative Screening}

- Compartment is screened if:

- It does not contain any equipment or cables from Tasks 2 or 3

- Fire in compartment will NOT lead to:

- Auto Rx trip

- Manual trip per plant procedure

- Required trip per plant tech specs or LCO

- Screened compartments will be reexamined in the context of multicompartment fire scenarios 


\section{Task 5 - Fire-Induced Risk Model}

- Internal events PRA modified to incorporate:

- Unscreened compartments

- Equipment identified in task 2

- Uses database developed as support task B

- Iterative process, model will be progressively refined 


\section{Task 6 - Fire Ignition Frequencies}

- Ignition sources in unscreened fire compartments

- Fire ignition bins and associated (generic) frequencies provided (Table $6-1,37$ bins)

- Frequencies updated with plant-specific data (if available)

- Locations mapped into generic locations (Table 6-2, 8)

- Weighting factors determined $\left(\mathrm{W}_{\mathrm{L}}\right)$

- Ignition source counts (\# of sources in compartment $J$ of location $\mathrm{L}$ )

- Weighting factors determined $\left(\mathrm{W}_{\mathrm{IS}, \mathrm{J}, \mathrm{L}}\right)$

- Transient weighting factors calculated for selected location

- Procedure provided, generic frequencies include transients 


\section{Task 7- Quantitative Screening}

- Fire PRA (from task 5) quantified for each compartment

- Ignition frequencies (task 6)

- All equipment in compartment assumed failed

- Screening HRA values used

- Criteria

- Total screened CDF $<0.1$ Internal Events CDF

- Total screened LERF $<0.1$ I.E. LERF

- Total screened ICDP $<1 \mathrm{E}-6$

- Total screened ILERP $<1 \mathrm{E}-7$ 


\section{Task 8 - Scoping Fire Model}

- Assesses the potential for ignition sources to affect equipment within a compartment

- i.e., fire $\neq$ auto failure of all equipment (task 7 )

- Walkdown each compartment/ignition-source

- Zone of Influence (ZOI) calculated for each source

- Some sources might be screened (no targets in ZOI

- Unscreened sources

- Heat Release Rate (HRR) estimated (tables provided)

- Severity Factors (SF) estimated based on comparison between calculated HRR for target (within ZOI) and $98 \%$ HRR of source (tables provided)

- SF used as a modifier on ignition frequency 


\section{Task 9 - Detailed Circuit Failure Analysis}

- Failure modes and effects analysis performed on all relevant cables in all un-screened compartments

- Information entered into Fire PRA database

- Cable failure modes

- Shorts-to-ground

- Hot shorts

- Failure effects

- Spurious operation

- Loss of power

- Loss of control

- Erroneous indication

- Others 


\section{Task 10 - Circuit Failure Mode Likelihood Analysis}

- Develops likelihoods for cable failure modes

- Table provided lists failure probabilities

- By cable type: Thermoset vs. Thermoplastic

- By raceway: tray vs. conduit vs. armored tray

- Computational method also provided

- More complex, but less conservative 


\section{Task 11 - Detailed Fire Modeling}

- Explicit identification and quantification of each fire scenario

- Each scenario includes a specific ignition source and specific target(s)

- Requires the use of fire modeling tools (for fire growth and propagation analysis)

- $\lambda_{\mathrm{k}}=\lambda_{\mathrm{i}, \mathrm{k}}{ }^{*} \mathrm{SF}_{\mathrm{k}}{ }^{*} \mathrm{P}_{\mathrm{ns}, \mathrm{k}}$

- where:

$-\lambda_{k}=$ frequency of fire scenario $\mathrm{k}$

$-\lambda_{i, k}=$ fire ignition frequency of source $i$, associated with scenario $k$

$-\mathrm{SF}_{\mathrm{k}}=$ Severity factor of fire scenario $\mathrm{k}$

- $\mathrm{P}_{\mathrm{ns}, \mathrm{k}}=$ non-suppression prob. of fire scenario $\mathrm{k}$

- Guidance provided for both SF and $P_{n s}$ for each of the 37 generic locations (see task 6) 


\section{Task 12 - Post-Fire HRA}

- Basically a Human Reliability Analysis for each fire scenario

- Identify and add Human Failure Events (HFEs) to Fire PRA model

- Develop initial screening values for Human Error Probabilities (HEPs)

- All HEPs set to 1.0, or

- Follow guidance procedure to assign all HFEs into 1 of 4 sets (e.g., set 1 = PRA value $\times 10$ )

- Detailed, best-estimate HRA analysis of important HFEs 


\section{Task 13 - Seismic-Fire Interactions Assessment}

- Fire Risk Scoping Study (NUREG/CR-5088, 1989) identified four issues

- Seismically induced fires

- E.g., rupture of a flammable material container

- Degradation of fire suppression

- Spurious actuation of suppression and/or detection

- Degradation of manual firefighting effectiveness

- Issues are assessed qualitatively, guidance is provided 


\section{Task 14 - Fire Risk Quantification}

- Combines all information into the Fire PRA model and calculates:

- Core Damage Frequency

- Large Early Release Frequency

- Identify dominant contributors to CDF and LERF

- Identify sensitivity studies to be performed 


\section{Task 15 - Uncertainty and Sensitivity Analysis}

- Integrated with all other tasks

- Each task includes identification of uncertainties

- In practice, two classes of uncertainties

- Modeling (logic, phenomenology, completeness, etc.)

- Data (e.g., statistical confidence)

- Identify which uncertainties will be addressed and how 


\section{Task 16 - Fire PRA Documentation}

- Documents background information, assumptions, and activities

- Should allow independent review of Fire PRA

- Suggested outline provided in guidance document 


\section{Task 17 - Plant Walkdowns (Support Task A)}

- Generally, several walkdowns are performed

- Initial (tasks 1 \& 2)

- Cable routing confirmation (task 3, 9, 10)

- Component count (task 5)

- Scoping fire modeling (task 8)

- Detailed analysis (task 11)

- Human reliability (task 12)

- Seismic fire interactions (task 13) 


\section{Task 18 - Fire PRA Database (Support Task B)}

- Detailed bookkeeping system

- components, cables, locations, compartments, sources, targets, etc.

- Relational database

- Sample database structure provided 


\section{Fire Risk Observations}




\section{Sandia Fire Risk Scoping Study (NUREG/CR-}

5088) Issues

- FRSS Issues:

- Seismic/Fire Interactions

- Fire Barrier Qualifications

- Manual Fire Fighting Effectiveness

- Total Environment Equipment Survival

- Control System Interactions

- Improved Analytical Codes

- Disposition of FRSS Issues

- The FRSS issues have been addressed qualitatively

- Review of plant design and other relevant documents, and plant walkdown 


\section{Insights from Fire IPEEE Review (NUREG-1742)}

- Analyses are based on FIVE (15), fire PRA (13) or a combination of methods (42).

- Fire CDF varied from 3.6E-08 per year to 1.9E-04 per year.

- Results varied significantly across analyses because of variations in methods, assumptions, and data used, level of conservatism, and quality of analysis.

- Fire can be a potentially important contributor to overall CDF.

- No consistent definition of vulnerability.

- Fire scenarios affecting the control room, cable spreading room, and switchgear rooms are major contributors to fire risk in many submittals. Turbine building was found to be important at some plants.

- Important locations, such as cable spreading room or control room, were screened from detailed analysis in some submittals due to low fire initiation likelihood. 


\section{Fire IPEEE Review (continued)}

- Electrical panel fires were the most significant fire CDF contributors in most submittals.

- Some submittals used optimistic guidelines and data described in NSAC/181 or EPRI's Fire PRA Implementation Guide.

- Optimistic assumptions made on electrical cabinet fires (excluded as credible fire sources, low heat release rates used, inter-cabinet propagation not considered, etc.).

- Screening of fire zones sometimes made on the basis of fixed ignition sources only.

- A few identified transient combustibles as significant. Some submittals dismissed transient fire sources from specific fire zones based on administrative control.

- Fire-induced transients (LOFW, MSIVC, LOSP, loss of support system) were found to be the most important accident sequences. 


\section{Fire IPEEE Review (continued)}

- Possibility of a fire causing an initiating event other than reactor trip is not always addressed.

- Fire-induced LOCAs, including spurious opening of SRVs/PORVs, were considered for many plants and were not found to be important. RCP seal LOCAs were found to be important contributors for many PWR plants.

- Most licensees screened all scenarios involving propagation of a fire from one zone to another or concluded that these scenarios were not significant.

- Failure of fire barriers has not have been properly accounted for in many cases.

- Only a few submittals explicitly treated potential variation in fire size for each fire area.

- Self-ignited cable fires generally assumed possible only for IEEE-383 unqualified cables. 


\section{Fire IPEEE Review (continued)}

- The possibility of a small fire damaging critical cables and equipment in close proximity within a very short time was not considered.

- For submittals that only considered Appendix R equipment cables, it is not clear that all IPE components and associated cables not included in the list of safe shutdown systems were assumed to be in failed states.

- Evaluation of fire-induced cable failure modes (e.g., hot short) was generally not discussed adequately.

- A simple model was used for fire suppression (automatic and manual combined). Many IPEEE submittals did not model manual fire suppression (except for control room fires).

- Generic values for suppression system reliability were used that were not based on system design features and compliance to the NFPA standards. 


\section{Fire IPEEE Review (continued)}

- Human errors were shown to be important. Operator actions in response to effects of fire (smoke, heat, loss of lighting, spurious indications, etc.) were rarely modeled in detail.

- Possibility of simultaneous multiple unit core damage not addressed.

- Shared area.

- Operator response to fire.

- Propagation scenarios between fire zones of adjacent units.

- Unavailability of cross-connected equipment due to outage at adjacent unit not accounted for.

- Insufficient details were provided in some submittals for the FRSS issues response; e.g., control system interactions, seismic/fire interactions. 


\section{Fire IPEEE Review (continued)}

- However, insights about plant features important to safe plant operation were gained, despite the above shortcomings. 


\section{Key Observations from Review of NPP Fire Events}

- Fire can pose a serious threat to nuclear safety

- SBO, loss of core cooling functions

- Operator actions are influenced by and do influence the chain of events in a fire incident

- Multiple fires are a possibility

- An initial event may lead to multiple fires

- A primary fire may lead to secondary fires

- Fire in non-safety areas may be important

- Large turbine building fires have had significant impact

- Non-safety switchgear fire 


\section{Key Observations from Review of NPP Fire Events (continued)}

- Materials of construction and plant layout can have a strong influence on the outcome of a fire.

- Smoke propagation can be an important element of a fire scenario.

- A fire involving cables may cause unexpected circuit faulting effects.

- Long duration fires may not be so rare. 


\section{Lessons Learned from NFPA-805 Pilots}

- Issues raised during pilot process being monitored and resolved via Frequently Asked Questions (FAQ) process

- Some issues resolved

- Some pending

- Some have defied resolution to date 


\section{Some "Closed" FAQs}

- FAQ 06-0016: Electrical cabinet counting guidance

- Provides clarifying examples of "vertical section" counting guidance

- FAQ 06-0017: High Energy Arc Faults in electrical cabinets

- Provides clarifying guidance for counting cabinets in the context of HEAF ignition frequency

- Provides a frequency split between low and medium voltage cabinets

- Clarifies treatment of HEAF in MCCs 


\section{Some "Closed" FAQs}

- FAQ 06-0031: Ignition source counting guidance clarifications and extensions

- Bin 14 - Electric motors: clarifies guidance, provides for excluding small motors of $5 \mathrm{hp}$ or less and totally enclosed motors.

- Bin 21 - Pumps: provides for excluding small sampling pumps, and other pumps of $5 \mathrm{hp}$ or less

- Bin 23 - Transformers: provides for excluding dry transformers of 45KVA or less

- Bin 26 - Ventilation subsystems: clarifies that intent is to exclude small subsystems powered by motors of $5 \mathrm{hp}$ or less (consistent with electric motors bin 14) 


\section{Some FAQs Pending Resolution}

- FAQ 07-0035: High energy arc faults in bus ducts

- Issue:

- Guidance document is silent on topic

- General approach to resolution:

- Acknowledge potential for such events (e.g., Diablo Canyon 5/2000)

- Provide plant wide frequency and counting/partitioning guidance

- Provide zone of influence and scenario development guidance 


\section{Some FAQs Pending Resolution}

- FAQ 08-0044: Large fires due to spilled oil

- Issue:

- Guidance for large oil spill and fire is generating conservative results especially in the case of MFW pump fires (high frequency of large release compared to experience base)

- General approach to resolution:

- Provide an alternative approach and revised fire frequencies for leaks and spills from higher volume circulating oil/lubrication systems 
Some FAQs Where Consensus Has Not Been Achieved

- FAQ 08-0046: Incipient Fire Detection

- Issue:

- Methodology provides no approach for crediting incipient fire detection systems

- General approach to resolution:

- Develop an approach that would credit these systems 


\section{Some FAQs Where Consensus Has Not Been Achieved}

- FAQ 08-0048: Fire frequencies

- Issue:

- Fire frequency analysis may not reflect industry trends (i.e., towards reduced fire frequencies

- General approach to resolution:

- EPRI has published interim report with updated frequencies

- Fire PRA Methods Enhancements: Additions, Clarifications, and Refinements to EPRI 1019189, Interim Report 1016735, December 2008

- NRC has not accepted EPRI results

- Discussion ongoing 


\section{Fire PRA Lessons Learned from NFPA-805}

\section{Pilots}

- Fire PRA component list will be larger than Appendix $R$ and internal PRA component list

- New components whose omission will be non-conservative:

- For multiple spurious operation considerations

- For fire-specific operator manual actions

- Cable selection is probably the single biggest factor that drives resource requirements

- Burden comes largely with the need to trace selected cables

- Need an accessible cable database, and constructing such a database from existing system may not be so easy

- Depends a lot on depth of cable tracing and nature of current tracking system 


\section{Fire PRA Lessons Learned from NFPA-805 Pilots}

- Circuit analysis may be far more resource intensive than expected

- Screening analysis producing high CCDP: when interlocks and permissives in internal events fault trees are failed, widespread equipment failure results

- Resolution of conservatism requires more, and more detailed, circuit analysis than anticipated

- Fire modeling in single compartments

- Hand calculations will suffice for many cases, but more sophisticated modeling (e.g., compartment fire models) also has a place

- Fire modeling in the main control room

- Fire zone or field models are necessary

- Will require detailed system analysis and HRA

- Smoke removal system can significantly impact abandonment and risk 


\section{Inclusion of Internal Fire Impacts in SPAR Models}

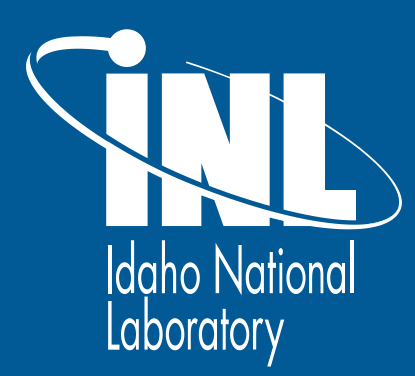




\section{Status of Fire Modeling in SPAR}

- Currently 21 SPAR models incorporate some aspects of fire impacts

- AP1000 (New design), Duane Arnold, Callaway, D.C. Cook, Davis Besse, Fermi, Shearon

Harris, Indian Point 3, Kewaunee (Shutdown), Limerick $1 \& 2$, Monticello, Peach Bottom 2 \& 3 ,

Salem, V.C. Summer, Surry $1 \& 2$, Turkey Point, Vogtle and Wolf Creek.

- Various sources and vintages of modeling data

- IPEEE's from the 90's

- FIVE analyses and older fire PRAs

- Current NFPA 805 compliant PRAs

- Many scenarios are rolled up/combined

- Typically only dominant contributors explicitly modeled in SPAR logic

- >90 percent of CDF

- >90 percent of ignition frequency

- Remaining contributors are included in catch all scenarios 


\section{Types of Fire Impacts Included in SPAR Models}

- Direct failures - event set to TRUE

- Fires assumed to fail equipment directly

- Damaged cables

- Increased failure probability values

- EPRI/NRC-RES Fire PRA Methodology

- Based on cable configurations and damage

- Spurious operations (including multiple spurious operations - MSO)

- EPRI/NRC-RES Fire PRA Methodology

- PORV Opening, ESFAS initiation, pump starts, valve repositioning, etc.

- Cascading effects (e.g., HPI MDP start leading to PORV opening)

- Human error increases 


\section{Two Approaches in Building Fire Event Trees}

Approach 1 - Damage assigned to a single dominant accident type

\begin{tabular}{|c|c|c|c}
\hline FIRE IN AREA 1 & $\begin{array}{c}\text { EVENT OCCURED } \\
\text { (PROB }=1)\end{array}$ & $\#$ & $\begin{array}{c}\text { End State } \\
\text { (Phase - CD })\end{array}$ \\
\hline IE-FRI-AREA1 & TRUE-FT & \\
\hline
\end{tabular}




\section{Two Approaches in Building Fire Event Trees}

Approach 2 - Damage assignment based on fault tree logic

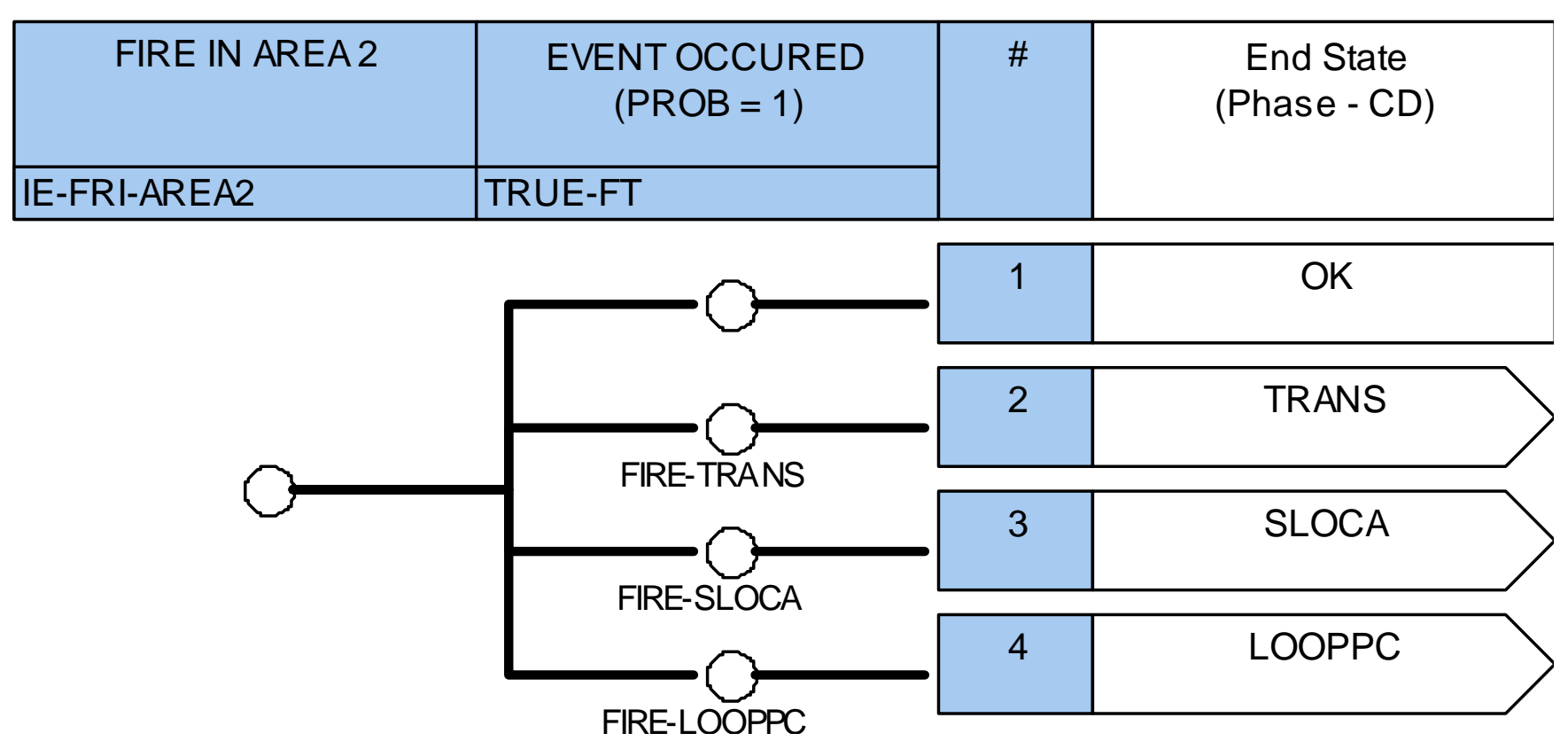




\section{Two Approaches in Building Fire Event Trees (cont)}

- Approach 1 - Single dominant accident type

- Pros

- Simple

- Minimal overcounting

- Cons

- Forces failures into a single transfer tree

- Approach 2 - Damage assignment based on fault tree logic

- Pros

- Logic is allowed to determine appropriate transfer

- Con

- Often leads to overcounting in sequence results

- (Endstate gather eliminates overcounting)

- Most SPAR models use approach 1 


\section{Flag Sets to Account for Fire Impacts}

\section{Flag Sets used to adjust logic events}

TRUE

FALSE

IGNORE

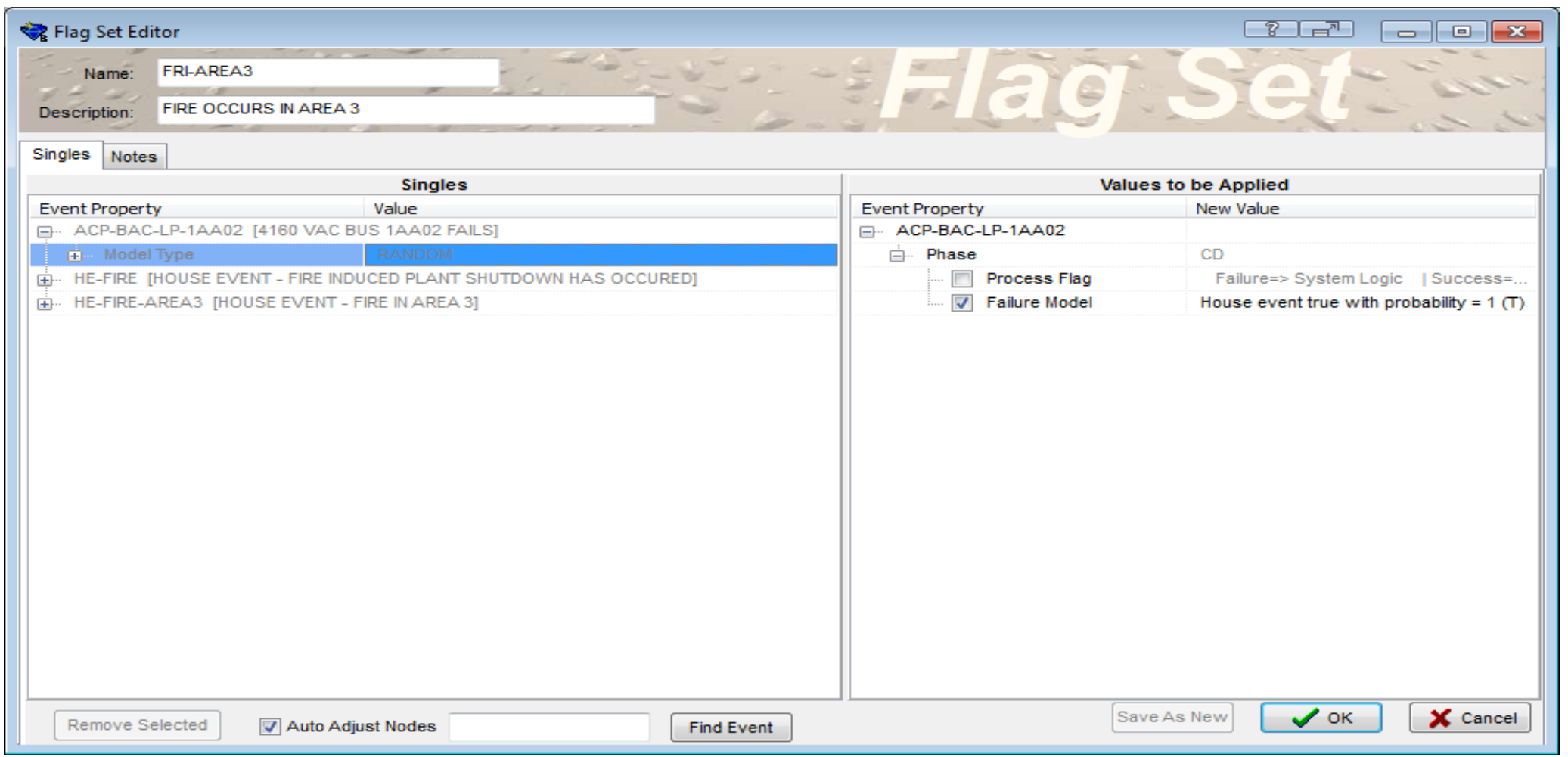




\section{Flag Sets Activated in ET Linkage Rules}

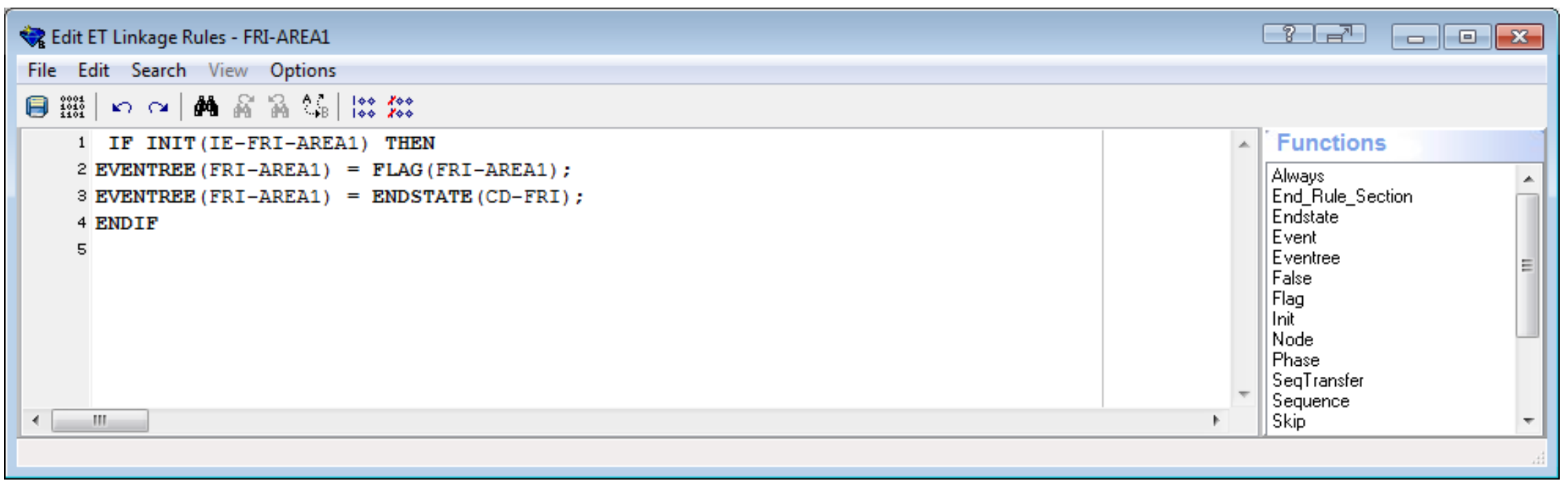




\section{Example of Spurious Opening}

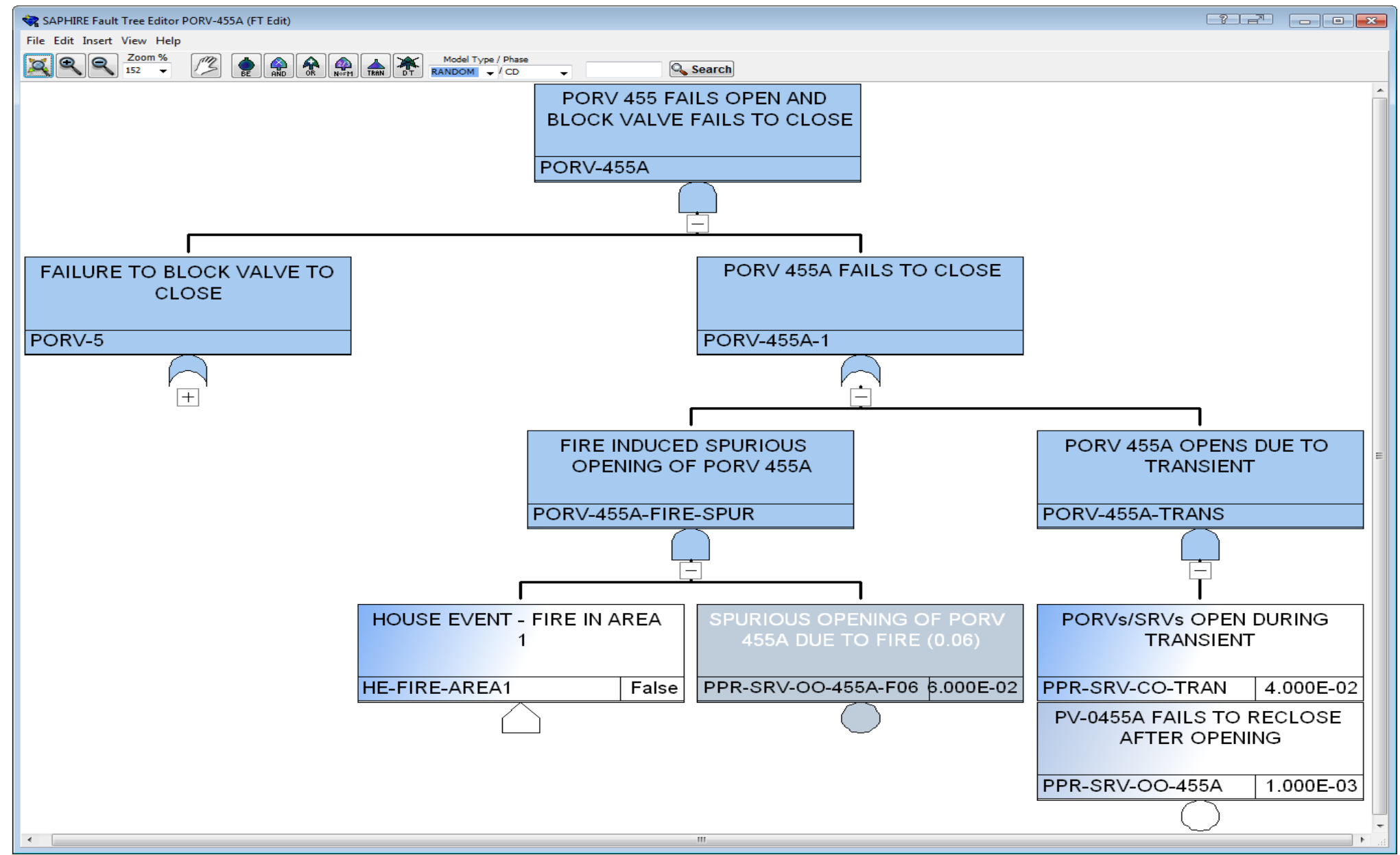




\section{Example of Direct Failure}

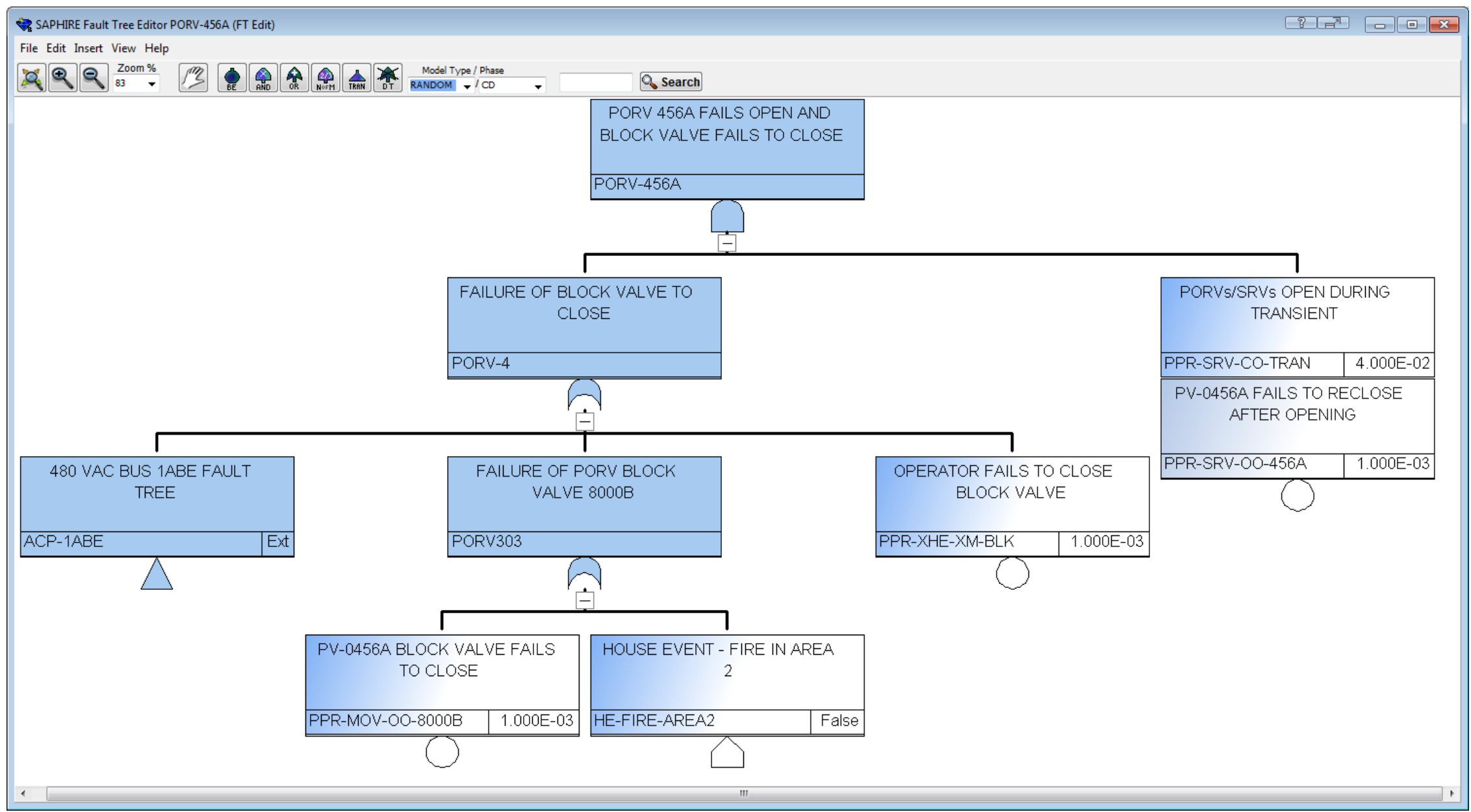




\section{Miscellaneous SPAR Fire Model Issues}

- Small error approximation may breakdown in fire modeling

- Potential for significant difference between sequence results and endstate gather results.

- SPAR reports EE-1, EE-2 and endstate gather provide reduced results.

- Fire ETs (and other external events) are unlinked in base SPAR Model

- Greater uncertainty in results lead to concerns about aggregation

- Deliberate action required to generate/incorporate fire results 


\section{Fire SDP vs. Fire PRA Concepts and Terminology}




\section{Concepts and Terminology}

- Objectives:

- Outline the basic quantification process used in fire risk analysis

- Define the factors that go into quantification

- Define key terms 


\section{Risk}

- Risk combines the likelihood that something undesirable will happen with the severity of resulting consequences

- In context of NRC mission, risk is most correctly measured based on potential public health consequence:

- Atomic energy act empowers NRC to establish and enforce standards governing the commercial use of nuclear materials and facilities as "the Commission may deem necessary or desirable in order to protect health and safety and minimize danger to life or property."

- That implies risk measures such as acute and latent fatalities

- Primary measure of fire risk is Core Damage Frequency (CDF)

- CDF is a surrogate for public health consequence risk

- Large Early Release Frequency (LERF) not used for fire protection SDP 


\section{How we estimate Fire CDF}

- We calculate CDF using four basic factors:

- Fire Frequency $(\mathrm{F})$

- Severity Factor (SF)

- Probability of Non-Suppression (PNS)

- Conditional Core Damage Probability (CCDP)

- Note that in fire PRA, SF is sometimes folded in as a part of ' $F$ ' or 'PNS' depending on analyst preference

- It is called out explicitly as a factor in fire SDP 


\section{Fire Risk (cont.)}

- For one fire scenario:

$$
\mathrm{CDF}_{\mathrm{i}}=\mathrm{F}_{\mathrm{i}} \text { * } \mathrm{SF}_{\mathrm{i}} \text { * } \mathrm{PNS}_{\mathrm{i}}{ }^{*} \mathrm{CCDP}_{\mathrm{i}}
$$

- Do as many fire scenarios as needed, add them up (carefully), and that is the risk estimate

- Roll-up risk values at different levels:

- One fire scenario

- One fire ignition source - multiple scenarios

- One fire area - multiple ignition sources

- One building - multiple fire areas

- Entire unit

- Entire plant site 


\section{Fire Risk (cont.)}

- SDP focuses on fire area roll-up

- Question: what is the risk impact of a specific performance deficiency?

- Deficiency is assumed to be tied to one or two fire areas

- We estimate risk for the impacted area(s)

- Remember that some issues cut across fire areas - examples:

- Post-fire manual actions

- Manual fire brigade

- Circuit analysis issues

- We don't do the cross-cutting issues (yet)

- You have to tie your finding to one or more fire areas

- No guidance for picking areas for a cross-cutting issue 


\section{Fire Frequency $(F)$ :}

- Definition: The likelihood that a fire will occur during some time period

- Time period is generally 12 months of at-power reactor operations

- one reactor year (ry)

- Calculated based on past experience

- Database contains nearly 1500 reported "fires"

- EPRI Fire Event Database updated through 2002

- Industry average capacity factors are factored in

- General units of measure:

- fires/ry 


\section{Fire Frequency (cont.)}

- You might hear that not all events reported as a fire hold the potential to challenge nuclear safety - TRUE!

- Events were "screened out" if there was no potential for a safety challenge

- The values provided for SDP should not be adjusted beyond the instructions provided - leave that to Phase 3

- In the end, we retain about $1 / 2$ of the fire "events" as potentially challenging

- Actual percentage retained depends on nature of fire source 


\section{Event screening}

- Sounds easy, but can lead to problems if you're not careful

- Important to maintain independence

- Other steps in analysis take credit for things you might be "counting" when you screen events

- Basic assumptions tend to flow from the "event set" you choose as representing your fire frequency

- Be careful when particular events appear to not be relevant to fire risk

- They might not be, but their basis for rejecting might be included with another factor credited elsewhere 


\section{More on Fire Frequency}

- Statistics give us the frequency of a fire somewhere, or involving something, in the plant

- Tied to a location or fire ignition source

- We assume this frequency is the same for all plants

- What we want is the frequency for a fire involving a specific ignition source in a specific location

- For most cases, component based fire frequencies do this directly - e.g., you get frequency for one motor

- In some cases we apply a partitioning factor to reflect a critical location out of all possible locations

- Area ratio factors - e.g., transients, welding

- Linear feet ratio factors - e.g., cable trays, control room panels 


\section{If We Need a Room Fire Frequency}

- We can use a generic fire area fire frequency based on average industry experience for similar fire areas

- SDP through Step 2.3

OR

- We can add up the contribution from all the individual sources in that particular fire area

- SDP beginning with Step 2.4

- Don't expect to get the same answer both ways

- For SDP, the generic values are intended to be slightly conservative - especially in Phase 1

- This won't be a universal truth, but differences should not be significant 


\section{Grouping Fire Ignition Sources}

- You can group some individual ignitions sources, and treat the group rather than each individual

- Common example is electrical cabinets/panels

- All members of the group need to be "the same"

- Fire characteristics

- Proximity to targets (damage) and secondary combustibles (fire spread)

- Frequency for the group is sum of frequency of each individual member

- If 10 panels, fire frequency $=10$ times frequency for a single panel 


\section{Severity Factor (SF)}

- General Definition: A value between 0 and 1 reflecting the fraction of all fires that are considered threatening in the context of a specific fire scenario 


\section{Severity Factors: Fire SDP}

- SDP approach ties SF to fire intensity

- Current PRA practice, but not same as typical IPEEE

- Why:

- Burn an electrical panel 10 times, and you'll probably get 11 different burn profiles

- Fire intensity profile is inherently uncertain

- All things being equal, still some fires will remain small, some will get big

- If it takes a big fire to cause problems (and it usually does) we reflect this through the severity factor 


\section{Severity Factors (cont.)}

- SDP Definition: SF = the fraction of fires big enough to cause damage to at least one potential target and/or spread fire to secondary combustibles

- We calculate "big enough" on a case-specific basis

- How big is the fire (use peak HRR)

- How close are the damage targets and secondary combustibles

- We use two HRR values for each fire ignition source

- Lower HRR represents $90 \%$ of all fires - SF $=0.9$

- Larger HRR represents worst $10 \%$ of fires $-S F=0.1$

- In effect we split each fire ignition source into two possible fires one big and one not so big

- If only the larger HRR leads to spread/damage, we end up with a net severity factor $-\mathrm{SF}=0.1$ 


\section{Illustration of SF Concept:}

- Even looking at a single fire ignition source, not all fires will be the same some will be big, some not so big

- Fire Intensity or heat release rate (HRR) is not a point value!

- We model uncertainty in peak HRR with a probability distribution

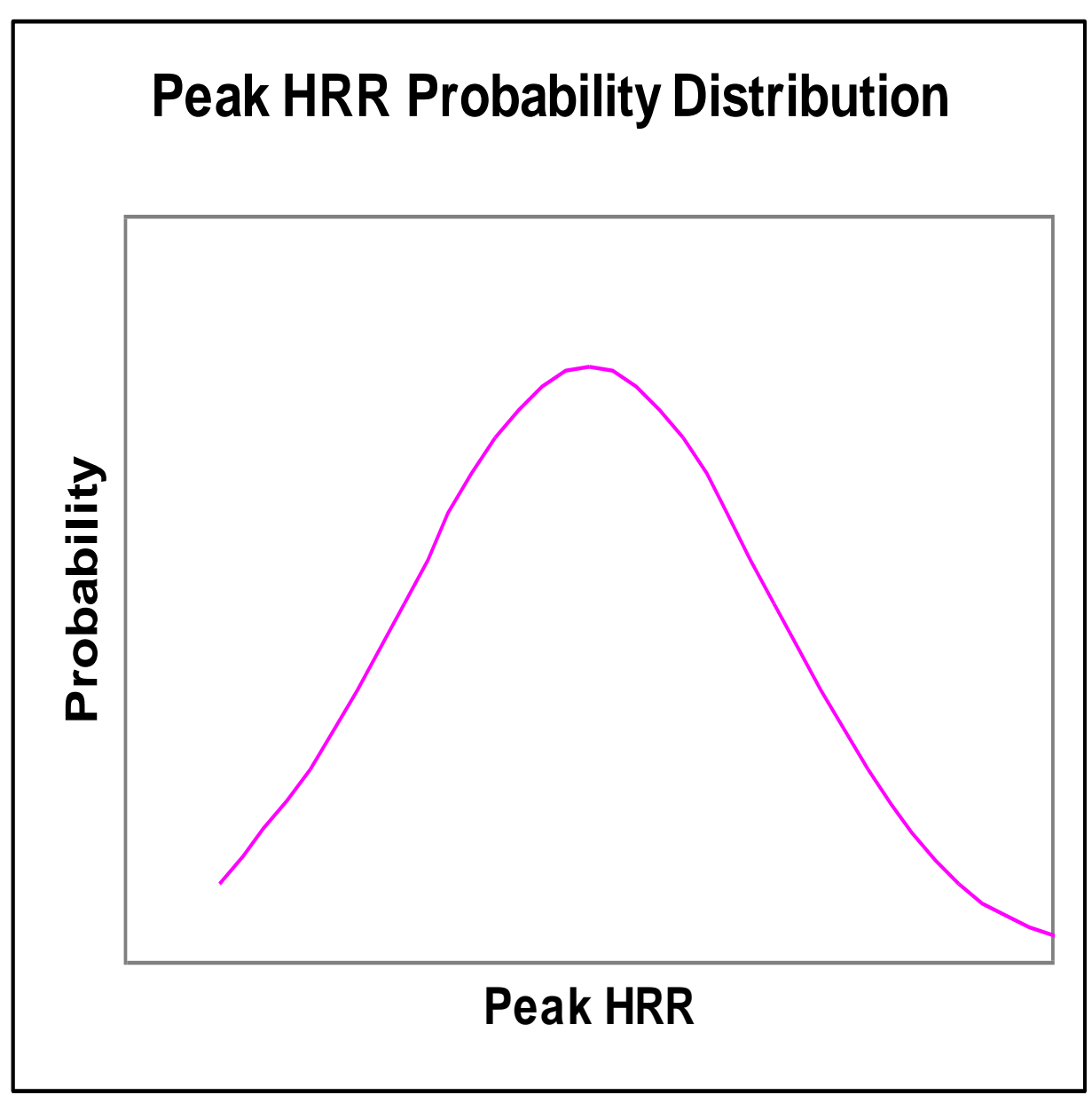




\section{Illustration of SF Concept - General}

- We look for the smallest fire leading to fire damage and/or spread

- Fires that large or larger are the "risky" ones

- We tie SF to the fraction of fires that large or larger

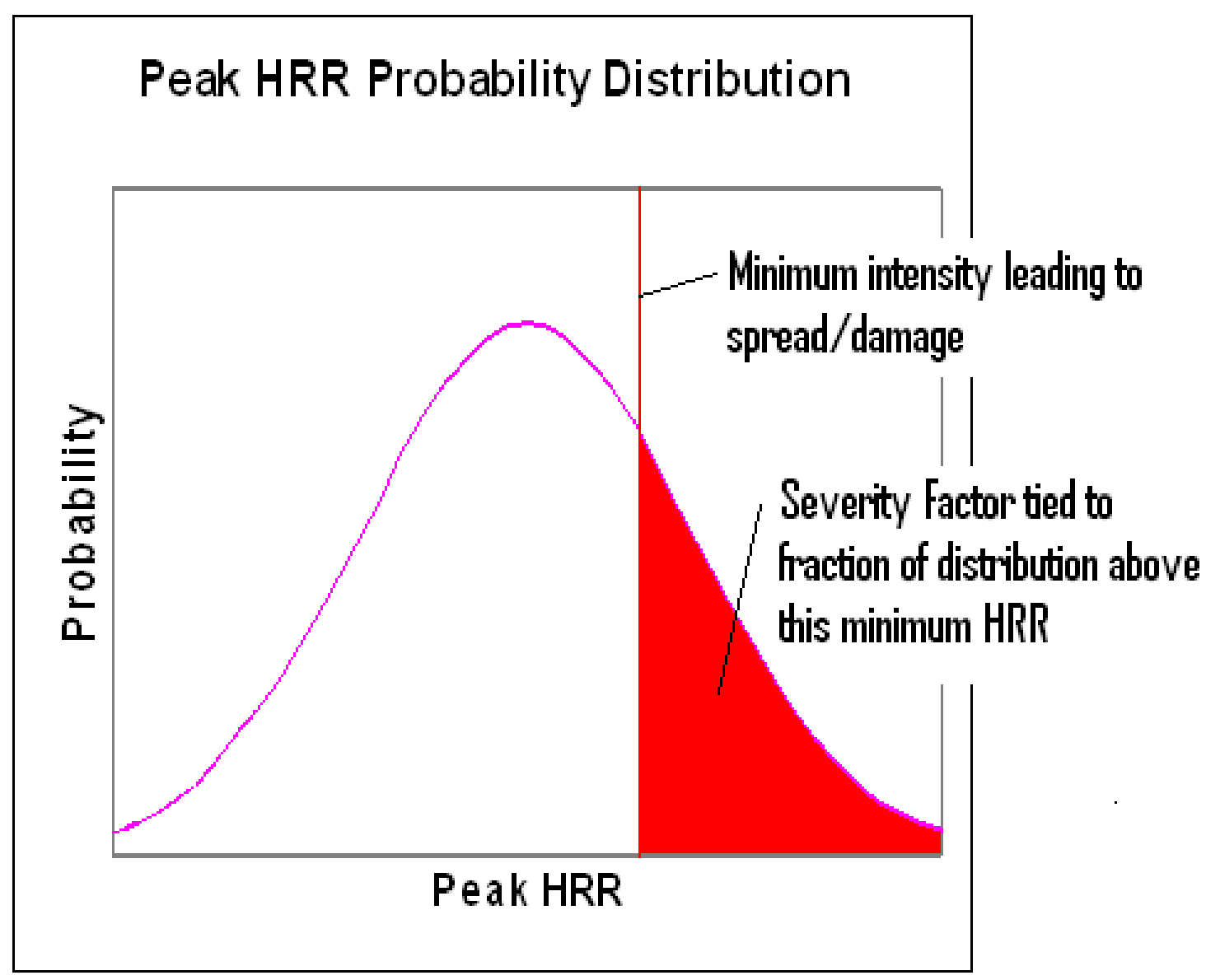




\section{Illustration of SF Concept - SDP}

- For SDP we use a simplified

PeakHRR ProbabilityDistribution version

- Two fire HRR values for each fire ignition source

- Expected value represents $90 \%$ of fires

- High confidence value represents $10 \%$ of fire

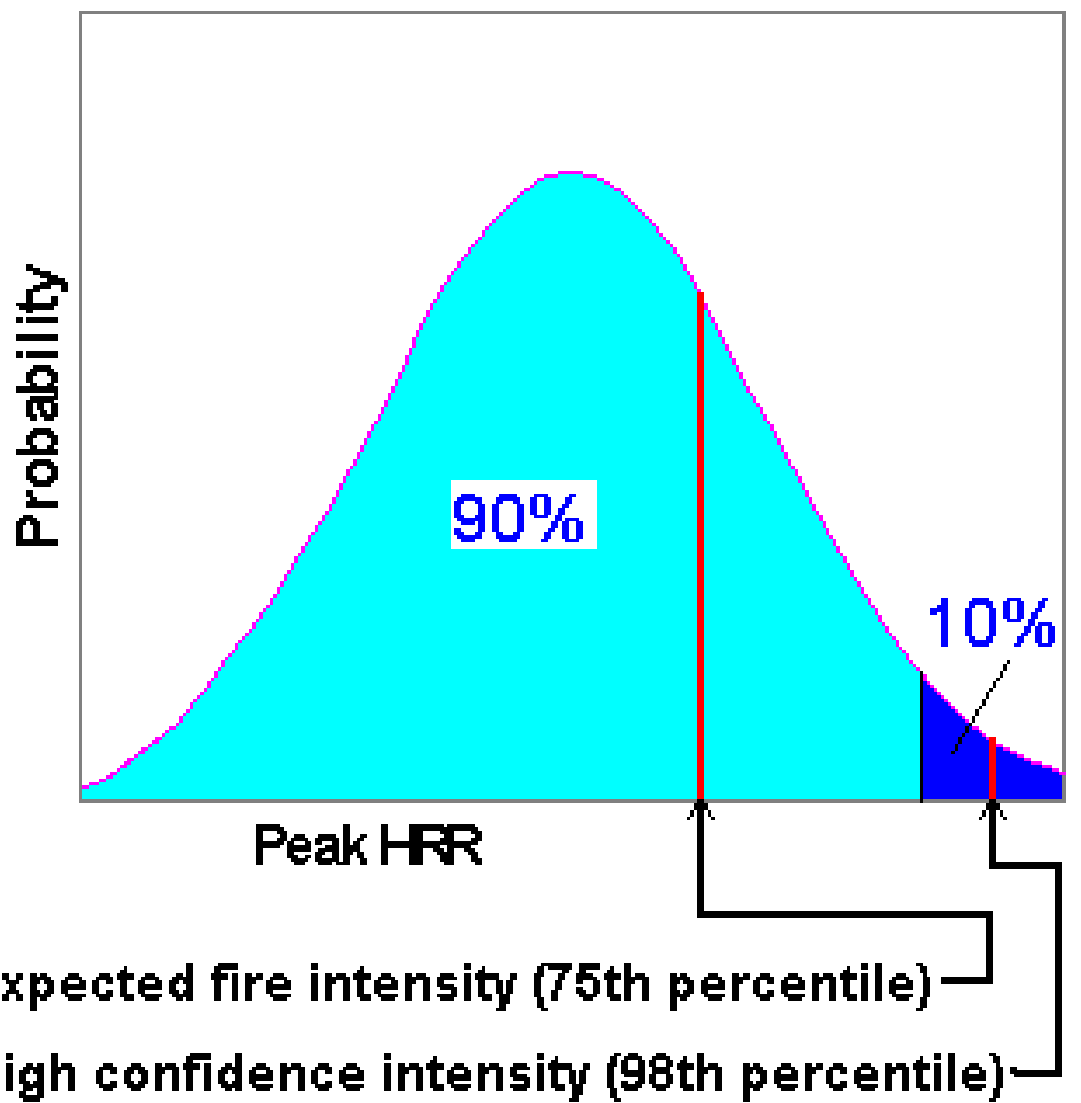




\section{SDP approach - quick review}

- SDP using simplified version of general approach

- Two fire intensity (HRR) values used represent the full distribution for each fire ignition source

- 'Expected' and 'High Confidence' or 75\% and 98\%

- Words/numbers not important - it's the concept that counts

- Assigned SF of 0.9 and 0.1 respectively

- You assess the spread/damage potential for these two HRR values

- The final risk results combine these two cases using SF as, in effect, a weighting factor on fire frequency

- Net severity factor depends on whether each intensity value causes damage 


\section{Obtaining HRR Values}

- Discrete HRR values were suggested based on NRC-sponsored research

- Review and discussion by SDP fire scenario team including NRC and Industry reps. - an expert panel

- Final values ultimately accepted for SDP

- Some adjustments made in HRR values to reflect SDP team/panel input 


\section{Severity Factor - Past Red Flag Issue for Fire PRA}

- Some cases of abusive application were seen in the IPEEEs, so take care when someone cites those

- Can find severity factors crediting:

- Prompt suppression, self-extinguished fires, fires that caused no trip, fires that did not spread, fires that did not damage secondary components, fires in non-vital areas, and ... the kitchen sink 


\section{Severity Factors (Summary)}

- Before you buy, remember the three "D"'s of PRA:

- Dependency, dependency, dependency

- The same factors may be accounted for elsewhere in the PRA either implicitly or explicitly

- When you see the use of one (or heaven forbid more than one) severity factor in quantification you have to ask if they are double counting somewhere 


\section{Probability of Non-Suppression (PNS)}

- Definition: PNS - The conditional probability that, given the fire, the fire will not be suppressed prior to the failure of a specific set of damage targets or ignition of secondary combustibles

- Key 1: Specific to a particular fire ignition source scenario

- May be a grouped set of fire ignition sources

- Key 2: Specific to a particular target set

- PNS reflects the probability that given the fire, these targets will fail or ignite 


\section{Target Set}

- A collection of components and/or cables that may be threatened by a postulated fire

- This could be anything from one cable to everything in the fire area 


\section{Target Sets (cont.)}

- The target set either survives or fails as a whole

- If you need to break down a target set, you really need to define more than one target set

- Target sets can be progressive if needed - one set represents expansion of another smaller set:

- Target Set $1=\{$ item 1$\}$

- Target Set $2=\{$ items $1,2,3\} \ldots$

- Helpful if two trains are threatened but separated (for example)

- Different fire ignition sources may have the same target set(s) or different target set(s) 


\section{Target Sets (cont.)}

- For any one fire ignition source:

- Most often one target set is enough

- You may define a series of expanding target sets reflecting growth and spread of the fire

- Don't go overboard - one, two, or at most three, should handle most situations 


\section{Target Sets (cont.)}

- Poor cable routing data actually makes this step easier

- If you don't know where specific cables are, you basically have to assume the worst

- Good cable routing data can actually complicate the choice

- You may be tempted to define many target sets as each tray becomes involved

- Don't - keep it simple 


\section{Back to PNS...}

- PNS is a 'probabilistic' horse race: time to damage versus time to suppression

- Time to damage depends on:

- How close targets are to the fire

- Target failure threshold

- How big the fire is

- Possibly: How quickly fire spreads

- The plant's chances of putting the fire out within this time depends on:

- What sort of fixed fire suppression capability is available

- Timing of manual fire response (e.g., the brigade) 


\section{Time to Damage}

-We can predict time to damage in three steps:

- Set the damage threshold

- Targets are usually cables

- Two basic cable types: thermoset (robust) and thermoplastic (wimpy)

- Predict the exposure conditions

- Plume, direct radiant heating, or hot gas layer

- Estimate temperature or heat flux at target location using Fire Dynamics Tool (FDT)

- Convert exposure condition to damage time

- SDP uses look-up tables 


\section{Damage Time Look-Up Table (Example*)}

\section{*Table A7.1 from IMC 0609, Appendix F, Attachment 7, 02/28/05}

\begin{tabular}{|c|c|c|}
\hline \multicolumn{3}{|c|}{ Table A7.1 - Failure Time-Temperature Relationship for Thermoset Cables } \\
\hline \multicolumn{2}{|c|}{ Exposure Temperature } & $\begin{array}{c}\text { Time to Failure } \\
\text { (minutes) }\end{array}$ \\
\hline${ }^{\circ} \mathrm{C}$ & ${ }^{\circ} \mathrm{F}$ & 28 \\
\hline $330 \leq \mathrm{T}<335$ & $625 \leq \mathrm{T}<634$ & 24 \\
\hline $335 \leq \mathrm{T}<340$ & $634 \leq \mathrm{T}<642$ & 20 \\
\hline $340 \leq \mathrm{T}<345$ & $642 \leq \mathrm{T}<651$ & 16 \\
\hline $345 \leq \mathrm{T}<350$ & $651 \leq \mathrm{T}<660$ & 13 \\
\hline $350 \leq \mathrm{T}<360$ & $660 \leq \mathrm{T}<680$ & 10 \\
\hline $360 \leq \mathrm{T}<370$ & $680 \leq \mathrm{T}<700$ & 9 \\
\hline $370 \leq \mathrm{T}<380$ & $700 \leq \mathrm{T}<716$ & 8 \\
\hline $380 \leq \mathrm{T}<390$ & $716 \leq \mathrm{T}<735$ & 7 \\
\hline $390 \leq \mathrm{T}<400$ & $735 \leq \mathrm{T}<752$ & 6 \\
\hline $400 \leq \mathrm{T}<410$ & $752 \leq \mathrm{T}<770$ & 5 \\
\hline $410 \leq \mathrm{T}<430$ & $770 \leq \mathrm{T}<805$ & 4 \\
\hline $430 \leq \mathrm{T}<450$ & $805 \leq \mathrm{T}<840$ & 3 \\
\hline $450 \leq \mathrm{T}<470$ & $840 \leq \mathrm{T}<880$ & 2 \\
\hline $470 \leq \mathrm{T}<490$ & $880 \leq \mathrm{T}<915$ & 1 \\
\hline $\mathrm{T} \geq 490$ & $\mathrm{~T} \geq 915$ & \\
\hline
\end{tabular}




\section{Automatic suppression time}

- We can predict time to actuation for an automatic suppression system using a simple spreadsheet tool

- E.g., a sprinkler head looks just like a heat detector

- Fire Dynamics Tool (FDT)

- That give us a number

$-\mathrm{x}: \mathrm{x}$ minutes:seconds 


\section{PNS for Automatic Suppression}

- We don't want to do a straight yes/no comparison between damage time and suppression time - this can be very misleading

- Damage time $=10 \mathrm{~min}$

- Suppression time $=9 \mathrm{~min}, 30 \mathrm{sec}$.

- Nominally suppression wins, but what is your confidence in this answer

- Is it really yes/no or fail/no fail

- To acknowledge uncertainties in the time estimates, we use the margin between damage time and suppression time 


\section{Probability Table for Automatic Suppression}

Probability of Non-Suppression for a fixed fire suppression system based on the time to damage equipment and the time required to suppress the fire

\begin{tabular}{ll}
\hline Time Delta $\left(\mathbf{T}_{\text {damage }}-\mathbf{T}_{\text {suppress }}\right)$ & $\mathbf{P N S}_{\text {fixed }}$ \\
\hline Negative time and up to 1 minute & 1.0 \\
$>1$ minute to 2 minutes & 0.95 \\
$>$ 2 minutes to 4 minutes & 0.8 \\
$>$ 4 minutes to 6 minutes & 0.5 \\
$>$ 6 minutes to 8 minutes & 0.25 \\
$>$ 8 minutes to 10 minutes & 0.1 \\
$>10$ minutes & 0.0 \\
\hline
\end{tabular}




\section{PNS and Manual Suppression}

- PNS for Manual estimated from empirical fire duration curves

- The vast majority of fires are manually suppressed

- We get fire duration data for enough of the reported fires to develop a fire duration curve

- Pick the appropriate duration curve

- Estimate $\left(t_{\text {damage }}-t_{\text {detection }}\right)$

- Remember that detection triggers manual response, but damage time measured from time of ignition $(t=0)$

- Pick off PNS manual

- Values also available in a lookup table 


\section{Duration Curve Example (PNS manual )}

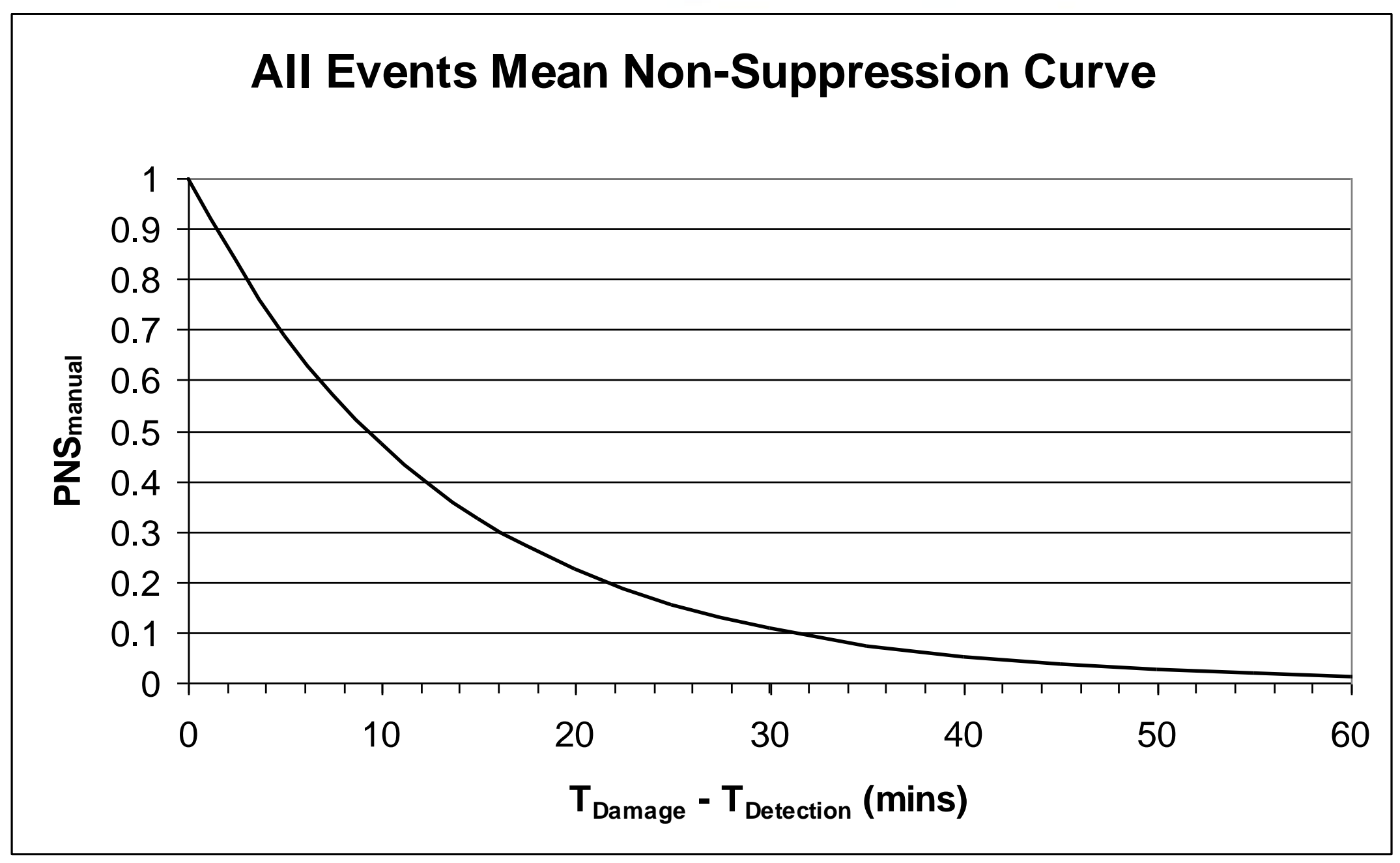




\section{Auto vs. Manual Suppression}

- If auto is present, we assume it will be primary suppression means

- If auto fails, manual is always the backup

- We assume that a water based automatic suppression system will fail on demand $2 \%$ of the time

- Gaseous systems - 5\%

- If no auto system, then manual is all there is 


\section{Manual fixed Suppression}

- Fixed fire suppression systems that have no automatic actuation mechanism - human action is required

- No hard/fast rule possible - use following:

- Estimate detection time

- Estimate physical response time

- Review decision criteria and estimate decision making time

- Nominal value is 2 minutes

- Increase if circumstances warrant

- Actuation time is sum of these three 


\section{Combining Manual and Auto-Suppression}

- Again, if auto system is present, it is assumed first line of defense

- Auto systems don't always work:

- Water based system $2 \%$ failure on demand

- Gaseous systems $5 \%$ failure on demand

- Values reflect both reliability and availability (out-of-service time)

- Manual is always available as a backup 


\title{
Combining Manual and Auto-Suppression
}

\author{
For Water-based systems: \\ $\mathrm{PNS}_{\text {scenario }}=\left(0.98 \times \mathrm{PNS}_{\text {fixed-scenario }}\right)$ \\ $+\left(0.02 \times \mathrm{PNS}_{\text {manual-scenario }}\right)$
}

For Dry-pipe and Gaseous systems:

$$
\begin{aligned}
& \mathrm{PNS}_{\text {scenario }}=\left(0.95 \times \mathrm{PNS}_{\text {fixed-scenario }}\right) \\
&+\left(0.05 \times \mathrm{PNS}_{\text {manual-scenario }}\right) \\
&{ }^{* *} \mathrm{PNS}_{\text {scenario }} \leq \mathrm{PNS}_{\text {manual-scenario }}
\end{aligned}
$$




\section{Special Consideration For Degraded Gaseous System}

- If gaseous suppression system cannot maintain adequate concentration for a sufficient time to assure fire extinguishment, then manual fire fighting must do the final mop-up

- The degraded gaseous system cannot permanently extinguish the fire, but does buy the fire brigade some additional response time

- We assume that the fire will be held in check during the time that the fire suppressant concentration is maintained at design level

- Upon dissipation of suppressant fire will re-flash

- We assume it will pick up right where it left off 


\section{Degraded Gaseous Systems (cont.)}

- To get $P N S_{\text {fixed }}$ we need to compare damage time to a suppression time-line with the following elements:

- Actuation time for gaseous system (manual or automatic as normally analyzed)

- The probability table that reflects our confidence that system actuation is timely compared to fire damage time

- Hold time / soak time for design concentration that system can deliver

- Manual response following loss of concentration 


\section{Degraded Gaseous System PNS Analysis}

- First we calculate a PNS for manual response as if gaseous system were not in place (or were to fail)

- Select the appropriate fire duration curve, based on ignition source

- Estimate fire detection time in the usual manner

- Assume a valid actuation signal on gaseous system will trigger a fire detection signal as well

- Calculate $t_{\text {damage }}{ }^{-t_{\text {detection }}}$

- Estimate $\mathrm{PNS}_{\text {manual }}$ in the usual manner 


\section{Degraded Gaseous System PNS Analysis}

- Next we look at timeliness of the system discharge:

- Estimate discharge/actuation time ( $\mathrm{t}_{\text {suppress }}$ ) as you would for any fixed system

- Could be automatic or manual actuation of fixed system

- Calculate the time margin ("Time Delta") between the actuation time and fire damage time in the normal manner

- Time Delta $=\left(t_{\text {damage }}-t_{\text {suppress }}\right)$

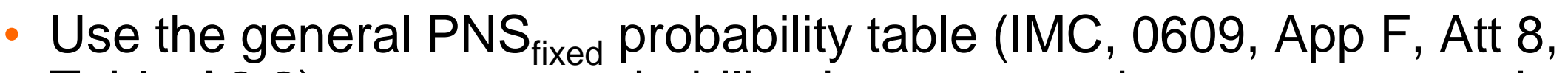
Table A8.2) to assess probability that suppression system actuation is timely in relation to estimated fire damage time. 


\section{Degraded Gaseous System PNS Analysis}

- Based on $\mathrm{PNS}_{\text {fixed }}$ decide whether to credit gaseous system at all:

- If $\mathrm{PNS}_{\mathrm{fixed}}$ is 1.0, then the gaseous system will not be credited.

- Use PNS scenario $=\mathrm{PNS}_{\text {manual }}$

- Analysis is complete.

- If $\mathrm{PNS}_{\text {fixed }}$ value is less than 1.0, then gaseous system will be credited.

- Continue this analysis to estimate PNS scenario. 


\section{Degraded Gaseous System PNS Analysis}

- Now do the case where the system buys some added time for fire brigade response:

- Calculate modified fire damage time as follows:

- $t_{\text {damage_new }}=t_{\text {damage }}+t_{\text {maintain_gas }}$

- $\quad$ where $t_{\text {maintain_gas }}$ is the time suppressant concentration can be maintained.

- Calculate modified time available for manual suppression:

$-\left[t_{\text {damage_new }}-t_{\text {detection }}\right]$

- Estimate $\mathrm{PNS}_{\text {gas_manual }}$ in the manner normally applied to $\mathrm{PNS}_{\text {manual }}$

- Use appropriate fire duration curve with the modified time available 


\section{Degraded Gaseous System PNS Analysis}

To get final $\mathrm{PNS}_{\text {scenario }}$ we now need to combine three cases:

- Case 1: Suppression system works (0.95 - no random failure), the actuation is timely (1- $\left.\mathrm{PNS}_{\text {fixed }}\right)$, and fire brigade fails to respond with extra time available $\left(\mathrm{PNS}_{\text {gas_manual }}\right)$

- Case 2: Suppression system works (95\% - no random failure), but discharge of the fire suppression system is not timely $\left(\mathrm{PNS}_{\mathrm{fixed}}\right)$, manual brigade must respond within original fire damage time (no extra time available - $P N S_{\text {manual }}$ )

- Case 3: Gaseous suppression system suffers random failure on demand (0.05), fire brigade must respond within the originally estimated fire damage time ( PNS $\left._{\text {manual }}\right)$ 


\section{Degraded Gaseous System PNS Analysis}

- And the final reduced equation is...

$$
\begin{aligned}
\mathrm{PNS}_{\text {scenario }} & =0.95 \times\left(1-\mathrm{PNS}_{\text {fixed }}\right) \times \mathrm{PNS}_{\text {gas_manual }} \\
+ & {\left[\left(0.95 \times \mathrm{PNS}_{\text {fixed }}\right)+0.05\right] \times \mathrm{PNS}_{\text {manual }} }
\end{aligned}
$$

- Verify that $\left(P N S_{\text {scenario }} \leq \mathrm{PNS}_{\text {manual }}\right)$

- As in other cases, the manual brigade response given the original fire damage time is the minimum credit given to fire suppression for any scenario

If $\left(\mathrm{PNS}_{\text {scenario }}>\mathrm{PNS}_{\text {manual }}\right)$ reset $\left(\mathrm{PNS}_{\text {scenario }}=\mathrm{PNS}_{\text {manual }}\right)$ 


\section{Conditional Core Damage Probability (CCDP)}

- Definition: The conditional probability that post-fire safe shutdown efforts will fail to achieve safe and stable hot shutdown conditions, thus resulting in core damage

- Risk analyses don't generally look at ability to achieve cold shutdown 


\section{CCDP (cont.)}

- CCDP is calculated using a post-fire safe shutdown plant response model

- Screening estimates may only credit the designated post-fire safe shutdown path

- For more detail, we use a broader plant response model that may credit components and systems beyond Appendix $\mathrm{R}$

- SDP uses the plant notebooks and pre-solved worksheets 


\section{CCDP (cont.)}

- We won't go into depth on this topic, but some high level rules:

- To credit a system or function, you must have reasonable assurance that it will not be damaged by the fire - your judgment counts

- We do credit manual actions - guidance is provided - but complex sets of actions will likely get little credit in Phase 2

- Spurious operations may be a part of CCDP calculation - you may need help here 


\section{That's pretty much it.}

$\mathrm{CDF}_{\mathrm{i}}=\mathrm{F}_{\mathrm{i}}{ }^{*} \mathrm{SF}_{\mathrm{i}}{ }^{*} \mathrm{PNS}_{\mathrm{i}}{ }^{*} \mathrm{CCDP}_{\mathrm{i}}$

Of course, the devil's in the details... 


\section{Fire Scenarios}




\section{More On Fire Scenarios}

- Definition: A fire scenario is a postulated sequence of events starting with the ignition of a fire and ending either in plant safe shutdown or core damage. 


\section{Fire Scenario}

-What is a Fire Scenario:

$($ Fire Scenario $)=($ fire ignition source scenario $)$

AND (fire growth and damage scenario)

AND (fire suppression scenario)

AND (plant SSD response scenario)

- Change any element and you have a new fire scenario! 


\section{Fire Ignition Source Scenario}

- Definition: Defines the physical characteristics of the fire that will develop for a particular fire ignition source - key factors:

- Placement of fire "origin" - how close is origin to targets

- Heat release rate (HRR)

- SDP bins fire sources by type, and ties characteristics to each type

- Five HRR values used to characterize all (simple) fires 


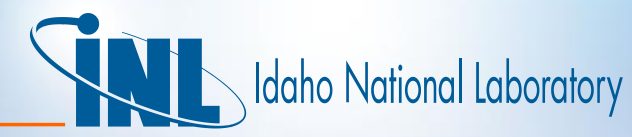

\begin{tabular}{|c|c|c|c|c|c|c|}
\hline \multirow{2}{*}{$\begin{array}{c}\text { FIre slze } \\
\text { Blns }\end{array}$} & \multicolumn{6}{|c|}{ Generle FIre Type BIns with SImple Predeflned Flre Characterlatlos } \\
\hline & $\begin{array}{l}\text { Smal| } \\
\text { Electrles } \\
\text { Flra }\end{array}$ & $\begin{array}{l}\text { Large } \\
\text { Elactrical } \\
\text { Flra } \\
\end{array}$ & $\begin{array}{l}\text { Indoor Oll- } \\
\text { Flllad } \\
\text { Transformers }\end{array}$ & $\begin{array}{l}\text { Very } \\
\text { Large FIre } \\
\text { Sources } \\
\end{array}$ & $\begin{array}{l}\text { Englnea } \\
\text { and } \\
\text { Heatere }\end{array}$ & $\begin{array}{l}\text { Sold and } \\
\text { Translant } \\
\text { Combuatibles }\end{array}$ \\
\hline $70 \mathrm{kM}$ & $\begin{array}{l}\text { Eg } \\
\text { Fercertle } \\
\text { Flre }\end{array}$ & & & & $\begin{array}{l}\text { Ed } \\
\text { Percentle } \\
\text { Flre }\end{array}$ & $\begin{array}{l}50^{\text {* Perontlle }} \\
\text { = he }\end{array}$ \\
\hline $200 \mathrm{~kW}$ & $\begin{array}{l}\text { 95n } \\
\text { Fetcentle } \\
\text { Flre }\end{array}$ & $\begin{array}{l}\text { Sgt } \\
\text { Percertile } \\
\text { Flre }\end{array}$ & & & $\begin{array}{l}\text { 95t } \\
\text { Percentle } \\
\text { Flne }\end{array}$ & $\begin{array}{l}95 \text { Percentle } \\
=\text { he }\end{array}$ \\
\hline $650 \mathrm{hW}$ & & $\begin{array}{l}95^{t} \\
\text { Percertlle } \\
\text { Flre }\end{array}$ & $\begin{array}{l}\text { 50" Percentlle } \\
\text { =he }\end{array}$ & $\begin{array}{l}50^{+} \\
\text {Percen:le } \\
\text { = lre }\end{array}$ & & \\
\hline $2 \mathrm{MM}$ & & & $\begin{array}{l}95^{*} \text { Percentlle } \\
\text { Flre }\end{array}$ & & & \\
\hline $10 \mathrm{MW}$ & & & & $\begin{array}{l}95^{+} \\
\text {Percen:le } \\
=1 r e\end{array}$ & & \\
\hline
\end{tabular}




\section{Fire Origin}

- The fire origin is a conceptual point at which we will assume the fire originates.

- Horizontal placement determines what is overhead and therefore in the fire plume

- Vertical placement will affect plume temperature for exposure of overhead targets

- Choice depends on the nature of the fire source 


\section{Heat Release Rate (HRR)}

- HRR characterizes the fire intensity or the amount of heat generated by a fire per unit time

- Typical units are either KW or BTU/hr

- This is generally the most critical of all fire characterization input values

- Remember - SDP ties fire intensity to severity factor 


\section{Convective / Radiative Fractions}

- Heat transfer from fire is via two primary mechanisms:

- Convective transfer- the mixing of hot fire products with ambient air resulting in direct heating of the surrounding air that in turn causes buoyancy and fire plume behaviors

- Radiative transfer- the luminosity of a fire's flame zone results in direct radiant heating of opaque targets (including soot-laden air)

- Recommended split fractions are:

0.7 convective, 0.3 radiative

- Paired values must sum to 1.0 


\section{Fire Growth and Damage Scenario}

- Definition: characteristics of fire spread to secondary combustibles if such occurs, and the behaviors leading to failure of an identified thermal damage target set

- You must define a target set (i.e., equipment threatened by fire that could affect safe shutdown)

- Damaging conditions may be created either due to burning of the ignition source alone, or due to fire spread

- If fire ignition source alone is not enough, and fire cannot spread, then damage is not possible 


\section{SDP Fire Damage States (FDS)}

- FDSO - loss of only the fire ignition source

- Not analyzed as a risk contributor

- FDS1 - localized damage near (especially directly above) the fire ignition source

- Keys factors: plume heating, upward spread of fire, and direct radiant heating

- FDS2 - widespread damage within a single fire area

- Key factors: horizontal fire spread, hot gas layer, and failure of degraded raceway fire barriers

- FDS3 - fire damage impacting two (or more) fire areas (room-to-room)

- Key factor: failure of an inter-compartment fire barrier element 


\section{Fire Detection and Suppression}

- We credit all available means of fire detection and suppression

- Detection is important mainly because it triggers the manual response

- Plant personnel become aware of the fire

- Fire procedures may kick in (check plant process for when this really happens)

- The fire brigade is activated

- Fixed automatic suppression systems require no prior detection signal, but usually are tied to alarm circuits 


\section{Fire Suppression (cont.)}

- Remember, in fire PRA/SDP space, it's a horse race

- Question is not so much "does suppression fail?"

- But rather, "does suppression fail to put out the fire before damage occurs?"

- All fires are put out (or go out) eventually - we want to know if suppression is timely in the context of our specific target set 


\section{$C C D P$}

- CCDP characterized plant/operator response to the fire

- Objective is safe shutdown (hot shutdown)

- This part can be complex 


\section{Developing a Fire Time Line}

- Key events on the time line

- Fire ignites (define this as time $=0$ )

- Fire is detected $\left(t_{\text {detection }}\right)$

- Manual/operator response begins

- Fire brigade is activated

- Target set fails ( $t_{\text {damage }}$ )

- Remember: $t_{\text {damage }}$ measured from $t=0$

- Automatic suppression activates ( $t_{\text {supp_auto }}$ )

- Manual suppression is successful ( $\left.t_{\text {supp_man }}\right)$

- Order of these events is TBD! 